Historic, Archive Document

Do not assume content reflects current scientific knowledge, policies, or practices. 




\section{Templin's "International" Pansies.}

The Greatest Collection of Strictly High Grade Pansies.

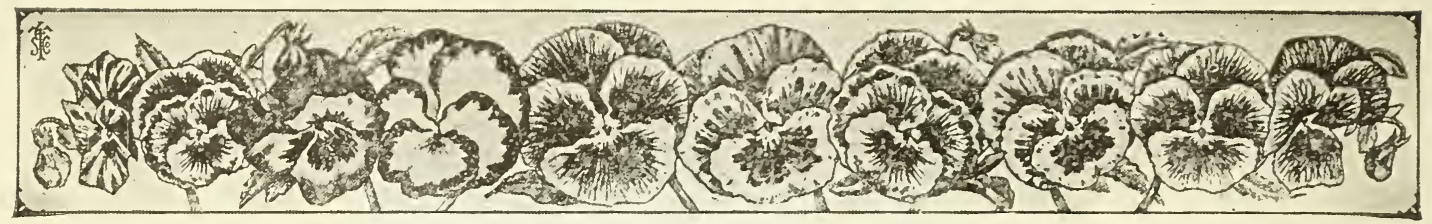

THIS ILLUSTRATION REPRESENTS THE VARIED MARKINGS, BUt NOT THE COLORS AND Size OF Flowers.

Since the year ${ }_{5} 5 \mathrm{~S} 7$, when Pansies were first discovered by Gerard, an English herbist and surgeon, they have been wonderfully improved in size and variety of colors. TEMPLIN's "INTERNATIONAL" are now recognized as representing the highest degree of perfection yet attained in Pansies. The glant flowers are well rounded and perfect in shape, with heavy, velvety petals. There are every known solid color, and every possible variation of colors, stripes, veinings, shadings, all blend in the inost wonderful and pleasing combinations. We call them our "International" Giant Pansies, because we have purchased the most distinct Giant Flowered varieties from each of the greatest Pansy specialists in America, England, Germany and France.

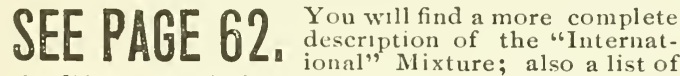
the different varieties and ty pes, with brief description of each. Price, 5 cts. per packet; 2 packets for $25 \mathrm{cts}$.

SEE PAEE 63 We where ofrec Tremplus: ULE HUL OJ. "Elite" Pansies consisting of rieties. IOc, per pkt; 3 for $25 \mathrm{c}$. Also our ExCEl.siok Mided Pansies; the best low price mixture. $5 \mathrm{cts}$.

Gentlemen: "I sent for a packet of your"Internat-I Gentlemen: "I want to express my appreciation of ional" Mixed Pansy Seed and planted them on the north your "International" Pansy seed. When I ordered them side of the house. Every one who saw the bed pronounc- Ilittle thought I should have such a fine bed of Pansies, ed it a wonder. They were the largest and finest Pans- living so far North. But they were the finest 1 ever saw; ies I ever saw." Yours, Mrs. G. Sherrill, Dyer, Wash. I except none." Mrs. WV. Mitchell, Edgerton, Minn.

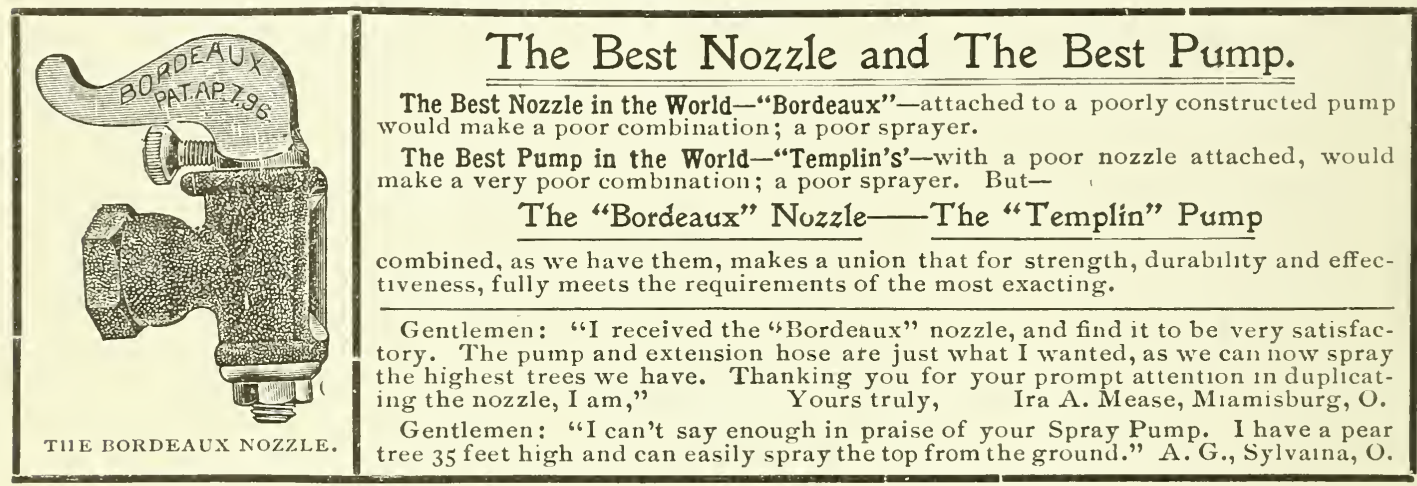

\section{SEE OUTSIDE BACK COVER PAGE.}

You can have great masses of gorgeous Asters and Pansies like those illustrated on upper and lower part of the design, where the beautiful effect possible to be obtained by proper planting in beds, groups and borders, is shown.

Just such beauty and brightness may be had by planting Templin's "Prize" Mixed Asters, or any of the varie(1) offered on pages 58 or $5 \%$, by judicious selection and arrangement of the kinds, tall and dwarf.

And the bed of Pansies; you can have just as fine a bed by planting Templin's "International" Giant Flowered Pansies. With each order for a packet we send a pretty booklet, giving history of Pansies, from the time they were first brought to notice, to the present. It also gives cultural directions which, if followed, will insure success.

\section{Templin's "Incomparable" Sweet Peas.}

Embraces Every Color and Shade Known Among Sweet Peas.

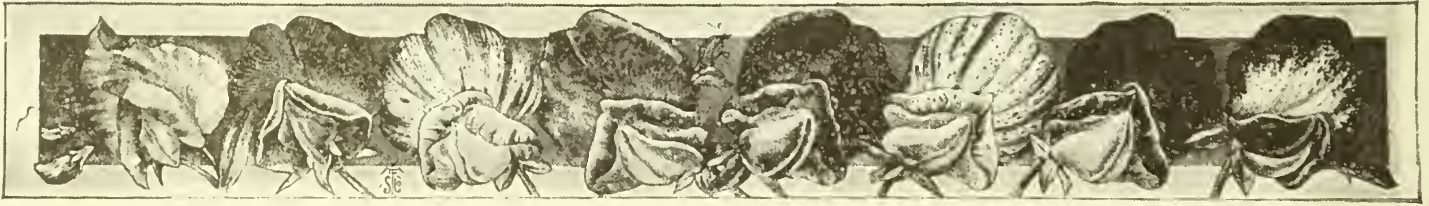

THIS SHOWS THE SHAPE OF FLOWERS AND MARKINGS, BUT NOT THE SIZE AND COLORS.

When we say that our "Inenmparable" Mixture contains roo Chorce NAMed VArieties we mean it; and they are the most distinct varieties possible to obtain. We know this to be the best mixture ever offered, as it contains the most varieties, many of which are of the latest introduction, including some of the celebrated "Spencer" type. See page 64 for names and descriptions of the 100 varieties and the way we prepare this superb mixture.

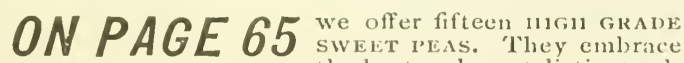
ors, and in size and beauty are anl that could be desirON PAGE 66 we offer ro Splendid New VaPAGE 66 rieties of the "SleNCE1R"type. ed. Price, each, pkt. large size, delicate shades and beautifully waved and dluted petals Price, $15 \mathrm{cts}$. per pkt; the 10 for unly yoe. 


\section{Announcement.}

The season of 1910 marks the beginning of our forty-sixth year in business, selling tested seeds, plants, shrubbery, nursery stock, small fruits and grape vines direct to the buyer. Our sales have increased year after year in good season and bad, proof that we have made it pay customers to buy of us. And yet we have never attempted to compete with otners in prices. We have sold our stock at a small margin of profit and owing to our method of testing and proving we have been atle to sell the highest grade stock at prices not in excess of those charged in many places for inferior goods.

For the coming season we desire to announce a new business departure. Hereafter we shall throw our entire knowledge 1 to the seed branch of our busmess, discontinuing other lines except a very few of the choicest varieties of choice fruts. By specializing along theselines we shall not only be able to give better values than ever before, but this plan has special advantages for the buyer.

The experienced grower has the advantage of buying from a compact list of tried and tested varicties, while the man of limited knowledge of varietıes will not be led astray by glowing descriptions of stock which often fails to make good.

In lookıng through this issue of our catalogue you will find the list of varieties while short yet long enough to contain the best. For vigor, vitality and splendid quality they cannot be excelled in adaptability to the varied soil and climate conditions of our country. No new variety is added to our general list until we have had the judgment and fair verdict of a large number of our patrons from all sections.

This system, coupled with our own past experience, constitutes a more extensive and comprehensive test of new varieties than the testing ground method as usually practiced. We have adhered strictly to this practice and thus have rendered it safe for any inexperienced gardencr to make purchases without fear. We solicit the orders of all users of seeds and especially those who do their own gardening and appreciate quality. Do not take a chance of an inferior crop, or no crop, and the loss of your season's labor by purchasing your seeds at the downtown grocery, when you can buy from Templin's, whose irame is associated with seed quality.

\section{Yours sincerely, L. Templin Seed Company, Calla, Ohio.}

\section{Important Suggestions.}

We would here call special attention to the following directions, which, if carefully followed, will be an aid • onr patrons as well as ourselves. Please remember to write plainly your Name, Postoffice, County and Staie.
Also give number of street or postoffice box as distinctly as possible. A little extra care along this line will greatly help us in forwarding your goods, and insure more prompt delivery.

TERMS: Cash with Order. All orders must be accompanied by CASH. We keep no book account with our patrons, and will in no case fill orders unless a remittance is inclosed to cover value of goods ordered.

HOW TO SEND MONEY. Of course our patrons are anxious to send money in the safest possible way. We recommend that you send by any of the following methods, in which case you send at our risk: Ist-Postoffice Money Order; secured at your postoffice. 2nd-Express Money Orders: secured at your Ex. ofhce. 3 rd-New York Draft; secured at your nearest bank.

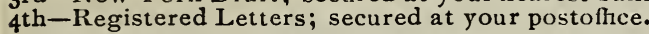

We will pay expense of forwarding money by any of the above ways, and you may deduct the cost from the amount of the Money Order sent.

STAMPS. We will accept stamps for very small amounts only, but since we offer to meet the expense of sending money by the above four ways, we trust you will not send stamps, unless absolutely necessary.

ORDER EARLY. As soon as this catalogue reaches you we are prepared to fill orders, and promptly. It will be greatly to your advantage to order early, as it can be filled before the great rush, and while our stock is unbroken. As a further advantage, you will have the seeds ready when the ground is first in condition for planting. Note our inducements for early orders.

USE THE ORDER SHEET and envelope inclosed when possible. Fill out all blanks carefully: es. pecially those giving your name and address. Write name and price of only one article on each line. Should you send more than one order, give your full address and the same name and address every time you order. Write all inquiries or instructions on a separate sheet.

SMALL ORDERS will receive just as careful and prompt attention as larger ones. We consider every order, however small, as all opportunit y to secure a larger one. With all orders for 25 cents and less we kindly ask you to send ro cts. to pay for packing, as the cost of labor and material are as great for a small order as a large one.

C. O. D. We do not send goods Collect on Delivery, as the cost of collecting charges is quite an unnecessary item of expense; and our prices being given in our catalogue, there is no reason why goods should be so ordered.
BY EXPRESS. By suecial arrangements with the express compantes, we can ship Seeds at a reduction of 20 per cent, from the regular rate. We recommend that if your order includes many seeds in quantities larger than packets. you order them shıpped by express, as you can generally save money by so doing.

BY MAIL. POSTPAID. All articles offered in this catalogue, except where offered by express, will be sent by mall, postpaid, to any Postoffice in the United States. It will greatly facilitate prompt delivery if you would give number of your route when ordering. Safet aganst freezing and other injuries would be secured if you would ask your mail carrier to protect your package.

SAFE ARRIVAL. We guarantee that all Seeds, \&c. shall reach our customers safely and in prime condition. Please examine carefully when received, and report promptly, should there be any cause for complaint. If package is injured or lost, by mail or express, report promptly after allowing for ample time to reach you. We will make satisfactory adjustment.

IT TAKES TIME for your order toreach us; (from one to five days;) and the same time for goods to reach you. Therefore please wait a reasonable length of time for goods before writıng, as it only hinders us in our correspondence and filling of orders if you become too impatient. Again, orders are sometimes lost and never reach us. Wait a reasonable time giving us two or three days allowance; then if goods are not received write us, giving date, copy of order and how remitlance was made.

ERRORS. We exercise the greatest care in filling orders; indeed, we strive to do even more than we offer, yet in the rush of orders errors will occasionally be made. We are always ready and anxious to correct all errors promptly. Please keep a copy of your order for comparison. Complaints for shortage, if any, must be made promptly on recespt of goods, and should be brief and you should mention order number.

ABOUT YOUR ADDRESS. Hundreds of orders are recelved every year from which some part of the ad. dress is omitted; usually the name. In such cases we are almost helpless. We are familiar with the names of all our goods and can read them even when poorly written, but your name and address, if poorly written, we can only guess at. Negligence along this line may cause de. lay and even total loss of goods. Therefore write plainly. CORRESPONDENCE. W s solicit your correspondence, and will endeavor to give prompt and courteous clearly, and on separate sheet from the order sheet: also that as few inquiries as possible be sent in during March and April, as we are always overtaxed with the business that is necessarily crowded into these two months. 


\section{Vegetable Seed Novelties for 1910 Free.}

\section{Cannot be Purchased for a Price This Season.}

On this and the opposite page we are offering four novelties of supposed great merit; that is, the originators claim great things for them. We want to be certain that they possess real merit in the different sections and soils of our country before offering them, at a price, in our general hist next year.

To prove their merit we will give one or more Packets to each of our patrons, for the purpose of having them tested in different locations and soils. THESE NOVELTIES ARE OBTAINABLE ONLY AS INDICATED BELOW.

\begin{tabular}{|c|c|c|}
\hline $\begin{array}{l}\text { A Free Packet of } \\
\text { ANY ONF. OF THESE NOVELTIES }\end{array}$ & $\begin{array}{c}\text { A Free Packet of } \\
\text { ANY TWO OF THESE NOVELTIES }\end{array}$ & $\begin{array}{c}\text { A Free Packet of } \\
\text { THE FOUR SEED NOVELTIES }\end{array}$ \\
\hline For a 50 Cent Seed Order. & For a 75 Cent Seed Order. & For a $\$ 1.00$ Seed 0rder. \\
\hline
\end{tabular}

The usual price for Vegetable Seed Novelties is from 15 to 25 cents per packet, but we give them free, asking only that you report on a postal card, your opinion of them for your climate and soil.

No new variety is added to our general list until we have the judgment and a fair verdict of a large number of our patrons from all sections. We believe this system of testing, coupled with our own experience and judgment, gives us a more comprehensive and reliable basis of value than is possible in any one Seedsman's "Trial Grounds".

\section{New Cucumber "Klondyke."}

A splendid variety of the white spine type. It is very early, com ing in with the extra early, and in quality ahead of all early or late. An abundant yielder, even under unfavorable weather conditions which causes many sorts to fall. When suitable to ship the fruits average two inches thick and seven inches long. Very dark green, striped with light green about one-third the length from the blossom end. The flesh is waxy white, crisp and of excellen Havor. Excellent for slicing.

Not for sale this season. Can be procured free by taking advantage of above otfer.

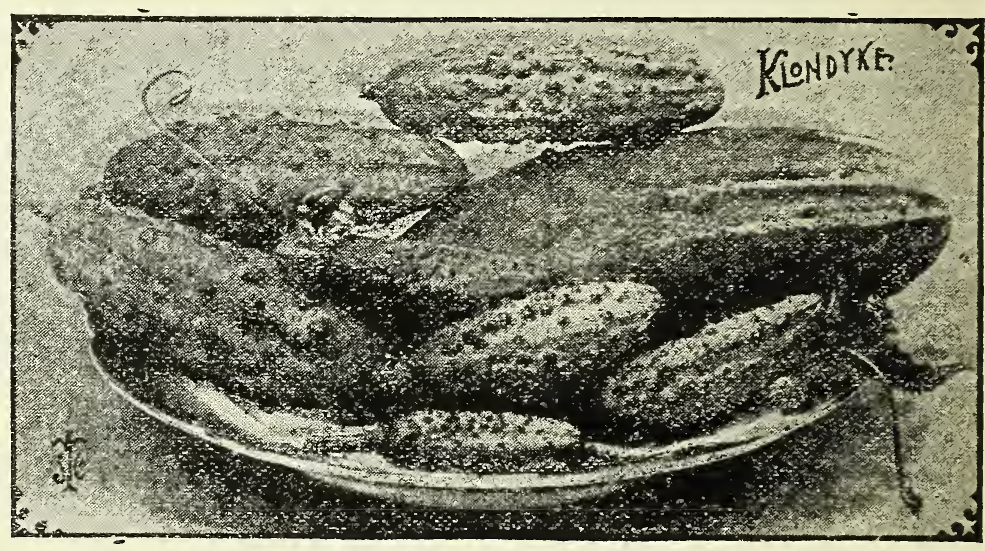

\section{New Giant Japanese Radish, "Sakurajima."}

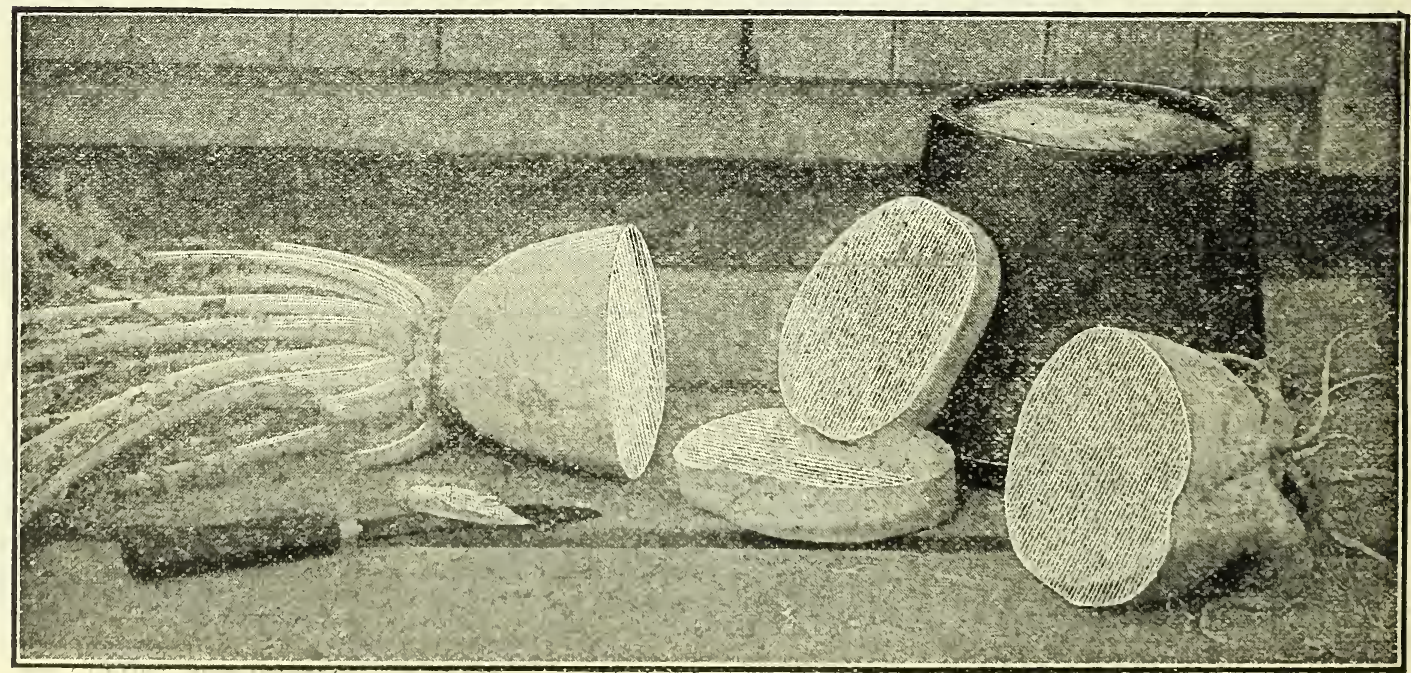

This is a distinct variety and one of the most valuable new vegctables introduced in recent years. Here is what the directors of the Ex. Station of Long loland Rallroad has to say about 1t: "The "Sakurajima." the Giant Japanese Radish, has come to stay. It is distunclly a summer Radish, and should not be planted until late; if planted early it runs to seed, Planted in the summer it will make immense oval bulbs, frequently weighing 15 to is pounds. Eaten raw it is as delicate as our best spring Radishes. Its tlesh is very much like an apple. Sliced, cut in squares, cooked and served as Turnips, it makes a dish that is hard to beat. It will keep all winter if given half a chance. Failures are made with it when planted before hot weather comes. It is an extremely easy plant to grow." The accompanying illustration is used by the courtesy of "The Fruit Grower,"St. Joseph, Missouri.

We do not sell "Sakurajima" Radish this year. Can be procured only by taking advantage of above Testing offer. 


\section{Templin's New Pop Corn, "Sure-Pop."}

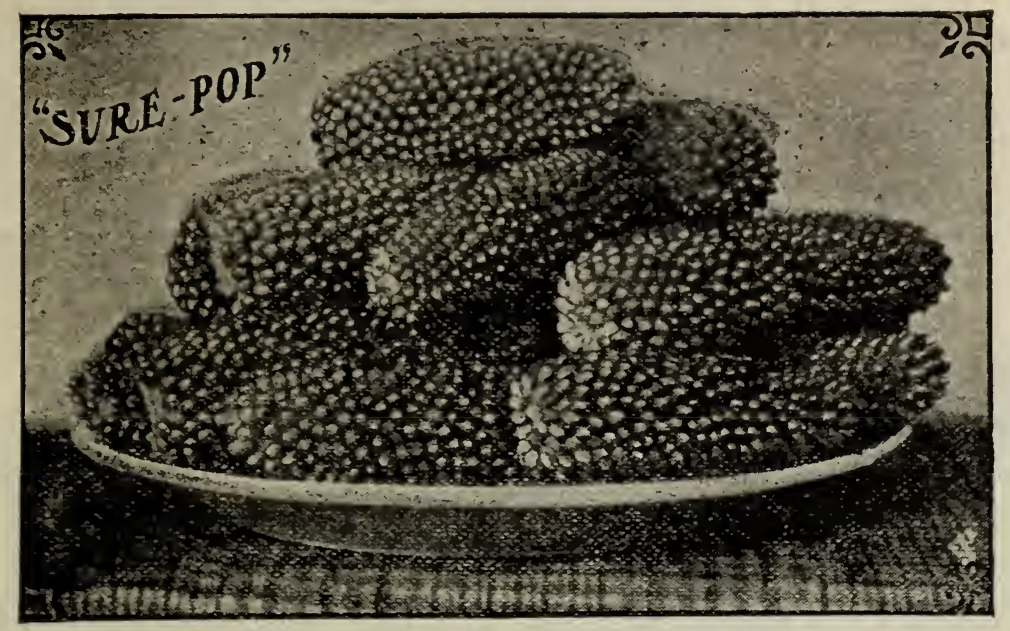

This is the best and most interesting Pop Corn novelty introduc. ed in many years. The grower, Mr. Huxley, from whom we pur. chased ourstock, has brought it to a high degree of perfection by many years of careful selection.

It is extraordinary in habit of growth; remarkably uniform in height, $4 \frac{2}{2} \mathrm{feet}$; stalks are sturdy, with very heavy follage and ears near the top, and remarkably pro. ductive, from 2 to 5 ears per stalk. The ears are rather small, from 3 to 4 inches long. Grains round, irregularly set in the cob; always filled out perfectly at both ends, cob small, white.

Mr. Huxley and all others who have used it say it is the best popper they ever tried, being rich, crisp and tender and entirely free from any hard, tough slell

Not for sale this season. Can be obtained only through "Premium offer." See opposite page.

U. S. DEP. OF AGRICULTURE. Gentlemen: "The variety of Pop Corn was planted May 1 Sth, and was fully ripe Sep. 20th. The stalks were remarkabiy uniform in regard to height, being about $4 \frac{1}{2}$ feet high. The ears numbered from 2 to 5 on a stalk and were well filled and of good quality." Yours, Ernest B. Brown, Assistant Phys.

\section{A Splendid New Tomato, "Coreless."}

The Most Perfect Canning Variety Ever Introduced.

This is another magnificent globe-shaped Tomato-t he type that is rapidly superced. ing the old flat and wrinkled varieties. It is also a product of the Livingstons, - their latest,-first offered last year. CORELESS is Large Size, Globe Shaped, Full at Stem End, a Strong Grower, Bright Red and Big Cropper. The Most Periect Canning Variety Ever Produced.

In "Coreless" the depression at the stem end has been al most eliminated, making it the most profitable variety forcanning, owing to the very small loss in material and labor. All the fruits are of marketable size, and many are quite large: 12 to 15 ounces. Always free from green core. A good slicing variety; the seed cells being surrounded by bright red, heary, meaty and delicious flesh, which is slightly more acid than the "Globe."

The strong outside and in. ner walls of flesh of the "Coreless" render it a firm fruit; one of the best for long dis. tance hauling or shipping. It ripens allover and through to the stem, all at the same time.

It is immensely prodactive, clusters of 4 to 7 fruits are pro. duced at 6 to $S$ inches apart along the stem. Every canner, market gardener or lover of good Tomatoes will appre. crate this superb Tomato.

The illustration, made from a photograph, shows the splendid shape and is about lifesize.

Not for sale this season. $\mathbf{O b}$ tained only by taking advantage of our "Premium Offer" as given on opposite page, you can get a packet free.

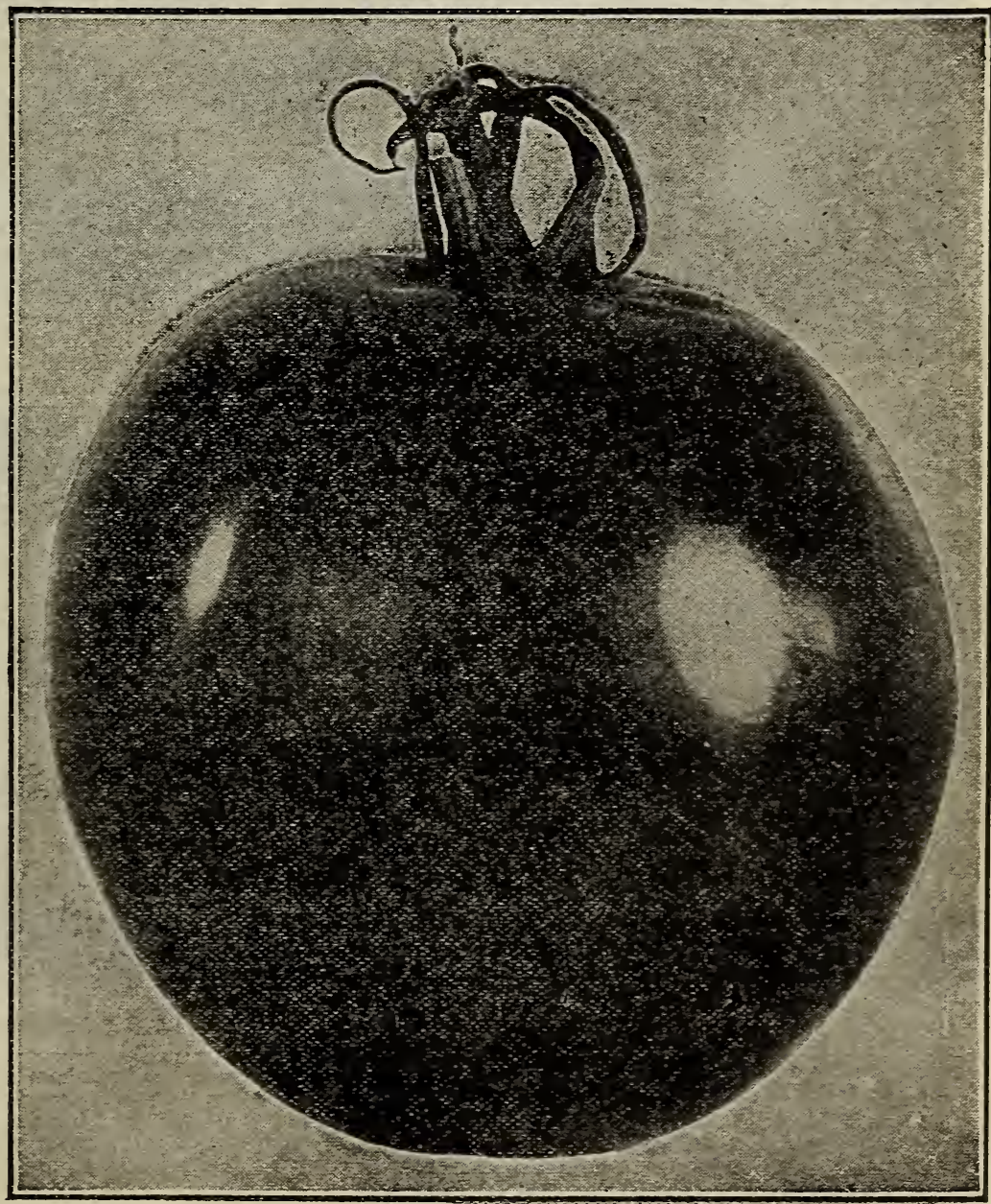




\title{
Vegetable Novelties and Specialties.
}

\author{
NEW AND OLD VARIETIES OF GREAT MERIT,
}

There are many pleasures connected with the Seed Business. Possibly the most pleasing is that of planting, watching the development, and noting the comparative values of the many new and old varieties on the trial grounds. And the pleasures of the home and market gardener need be noless genuine, as they note the germination, development and strange characteristics of the latest novelties, as compared with standard old varieties with which they have long been familiar. These arealwass interesting because of the possibilities of their being better adapted to the prevailing soil and climatic conditions than the standard old varieties.

On the following eight pages will be found illustrations and descriptions of new and old varieties that have been carefully tested on our own trial grounds and proven their real merit. They are also highly endorsed by the leading seed specialists, farmers and growers throughout the country. We do not hesitate to recommend them to our patrons. We are confident they will prove satisfactory.

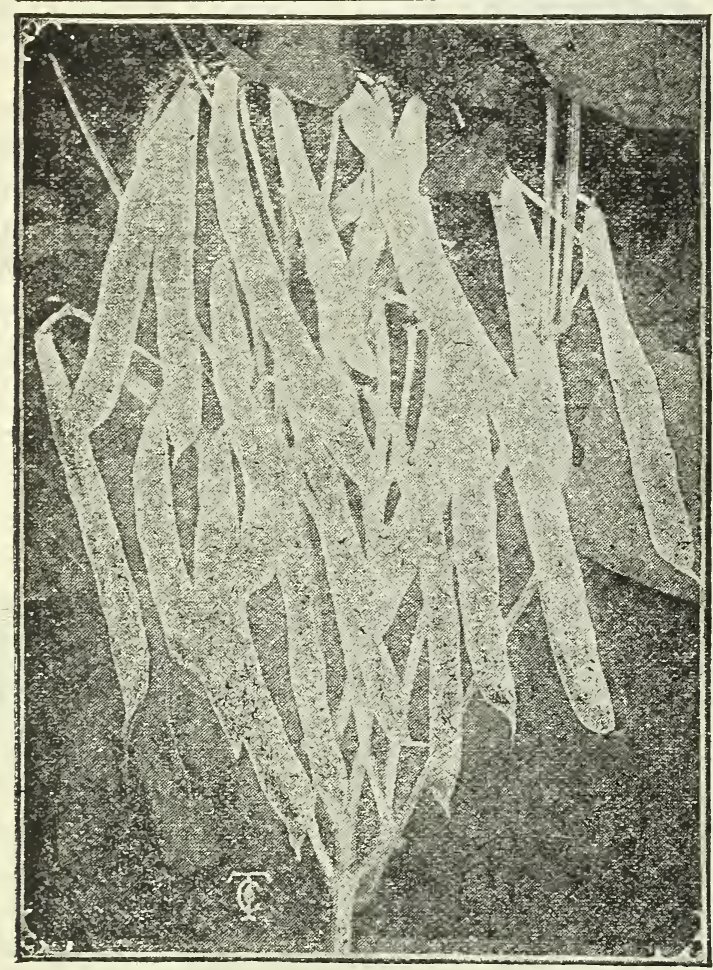

Davis' White Wax Bush Bean.

Most vigorous; Very productive; Unexcelled in quality. Best for Home and Market.

At last we have an enormously productive wax podded Bush Bean, having clear white seeds. Pods long, straight and handsome; plant very vigorous and productive. As nearly rust proof as any known variety. After giving this variety a thorough trial in our grounds we consider it the best white seeded Wax Bean grown. It is of unusually strong growth, and holds its splendid pods well above the ground. It is used both as a snap short and a shelled bean. It is of extremely high table quality and is unexcelled for canning purposes. Everything considered it is one of the very best for the home and market garden. Price, large 2-ounce packet, sufficient for 30 hills, 10 cents; $1 / 2$ pint 15 cents; pint 25 cents; quart 40 cents, postpaid. By express, quart 30 cents: peck $\$ 2.00$.

\section{Burpee's Stringless Green Pod} Bush Bean.

\section{Extremely eariy; Very productive; Absolutely string-} less. Positively unexcelled in quality.

Though not a new variety, it is one of the most valu. able. It is an extremely early, green pod, stringless Bush Bean of great merit. In habit of growth it is similar to the popular Valentine, but develops pods to edible condition three to four days earlier, or in about 30 days from germination. It is very productive, bearing beautiful, straight, smooth, tender, green pnds in the greatest abundance, being absolutely stringless, breaking off as short and smooth as pipe stems. In a word, this variety is conceded to be the most desirable green pod variety ever introduced. We sell more of this variety than of any other two combined, and our strain of seed is the very best ever offered, being produced by the old est and most reliable growers. Price, $10 \mathrm{cts}$. per 2-oz. plit., enough for 30 hills; $1 / 2$ pt. 15 cts.: pt. 25 cts.; qt. 40 DAVIS' WHITE WAX BUSH BEAN. cts., postpaid. By express, qt. 30 cts; $\mathrm{pk}, \$ 2.00$.

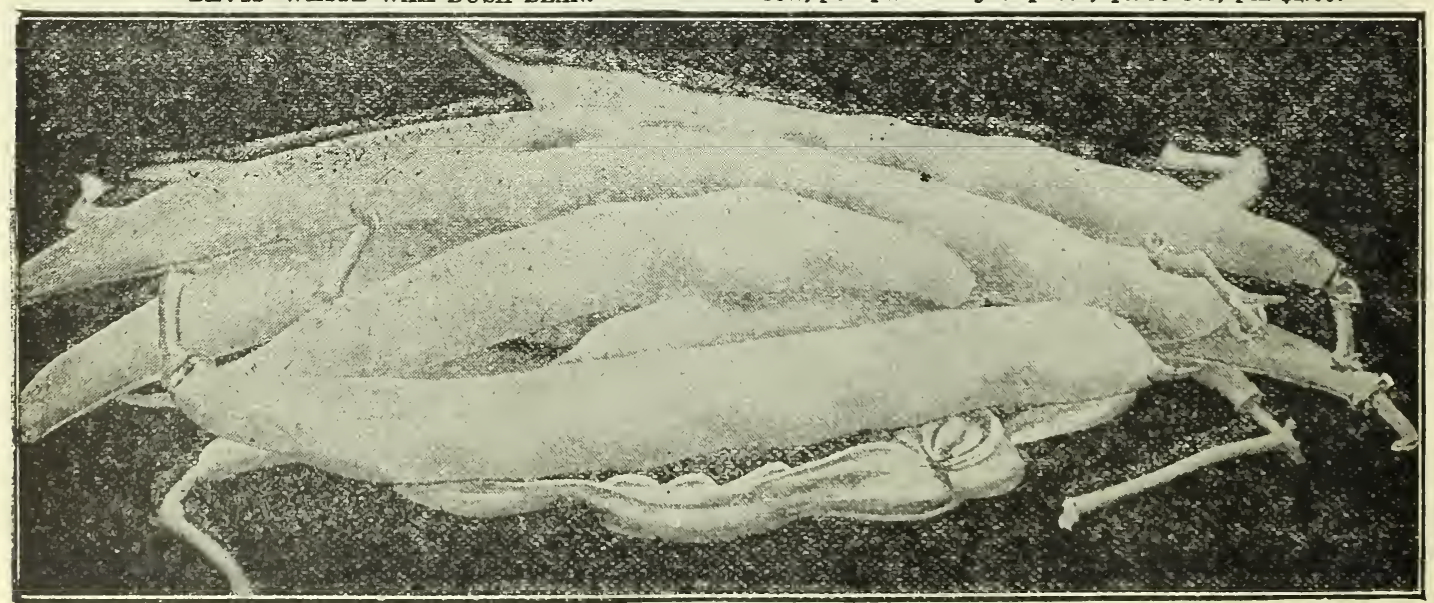

BURPEE'S STRINGLESS GREEN POD WAX BUSE BEAN.

Templin's Seeds Grow. We know they will because we give them a thorough test. Each season just ty does not give a satisfactory germinating test we destroy them and buy others. We can tell you exactly the per cent. of germination of each variety. The more important question is, however, what will they produce? We know our growers. The high quality of their products is lnnwn hy our patrons, whose confidence we have had for the past 14 Jears. Our patrons say concerning Templin's seeds, "Thcre are none better." 


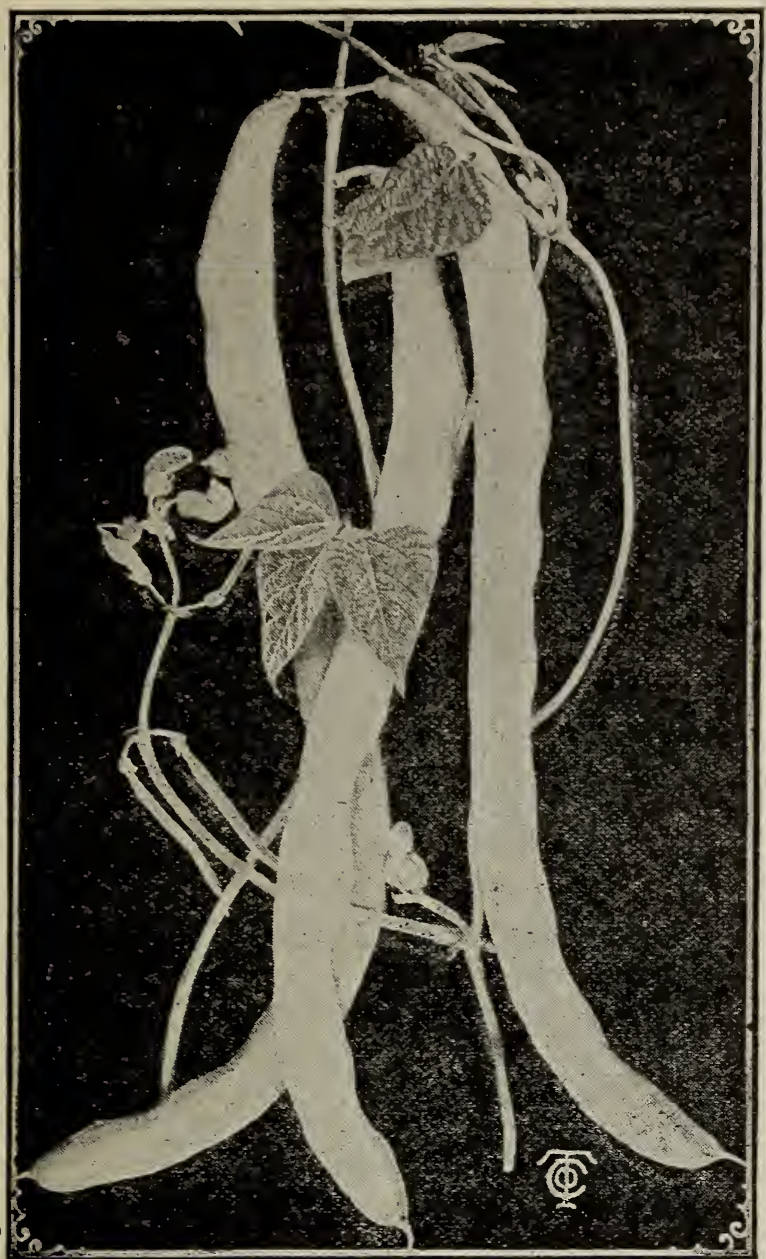

KENTUCKY WONDER.

\section{Extra Early Jersey Lima Bean.}

The Earliest. Immense Size. Wonderfully Productive. Unexcelled In Tenderness and Quality.

Though an old variety, it is without doubt the most profitable Lima Bean ever offered. The best for practical farmers and truckers who wish to be the first in the mar ket. It is fully one week earlier than any of the large Pole Limas, and two weeks earlier than most, consequent ly a boon to many growers, especially in sections where the season is short. The result of careful selection and breeding for earliness, a green bean and thin pod. A vigorous grower; beans of large size, most excellent quality and enormously productive. Produced in clusters of 5 to pods each, always well filled. Everywhere admitted to be a strain of exceedingly high merit. Price, 2-oz. pkt. Ioc.; pt. 25 c.; qt. $40 c$. By express, qt. 30c.; pk. \$2.25

\section{Burpee's Improved Bush Lima.}

\section{The Best Bush Lima Grown.}

\section{A Prolific Bearer. Luscious Flavor. Needs No Poles.}

The most popular variety in this class. Its popularity is due to its dwarf, bushy growth, requiring no poles or brush. There are several types of the Bush Limas, each having its peculiar merits, but this is now most largely grown. The plant grows 18 to 20 inches high, and is of erect, branching habit, having strong stems. It is the most prolific bearer, each bush producing from 50 to 100 handsome marketable pods, well filled with large beans, only a little smaller than the Pole Limas, and fully equal to them in luscious flavor. For earliness and productiveness it is unexcelled. Their earliness enables them to be grown successfully in many sections where the seasons are too short for Pole Limas. This variety possesses more good qualities than any other Bush Lima Bean grown. Packet, containing 2 ounces, enough for 30 to 40 hills, ro cts; pint 25 cts; quart 40 cts. By express, quart $30 \mathrm{cts}$; peck $\$ 2.25$.
Kentucky Wonder Pole Bean. "Old Homestead."

Very Early. Ever-bearing. Entirely Stringless. Best for Home and Market.

We can heartily recommend this as one of the earliest and most satisfactory of all (jreen Podded Pole Beans. It is about ten days earlier than any other green variety, and is a marvel of perpetual productiveness, if they are all gathered when ready for "snaps" and none a re allowed to mature on the vines. The pods are from 8 to 10 inches long, silvery green in color, hanging in great clusters from top to bottom of vines. While young the pods resemble the popular old Refugee. They are entirely stringless, plump, round and solid, cooking very tender, and are of most excellent flavor. This is the best and most profitable Bean for the market gardener, the pods being so showy and produced in great abundance. Pkt. $10 \mathrm{cts} ; 1 / 2 \mathrm{pt} .15 \mathrm{cts} ; \mathrm{pt}$. 25 cts; qt. 45 cts. By express, qt. 35 cts; pk. $\$ 2.25$.

\section{Wardwell Kidney Wax Bush Bean.}

Immensely Productive. Unexcelled in Beauty and Quality. Rustproof. Stringless.

This is one of the earliest, hardiest and most productive of all Wax Beans. One of the most valuable points in its favor is that it is almost free from rust, and invariably strong and healthy. The pods are long and of a delicate waxy-yellow, assuming its color at a very early stage of its growth. The mature beans are large, kidney-shaped, pure white with dark markings around the eye. Not only a first-class snap bean, but equally valuable for dry shell beans in winter. They are of good quality and always command a ready sale, making the variety one of the most profitable for the market gardener. Matures with the Rust Proof Golden Wax, and we consider it fully equal. There are many gardeners who prefer this variety to all others. Pkt. Io cts; $1 / 2$ pint 15 cts; pint 25 cts; quart 45 cts. By express, quart 35 cents; peck $\$ 2.25$.

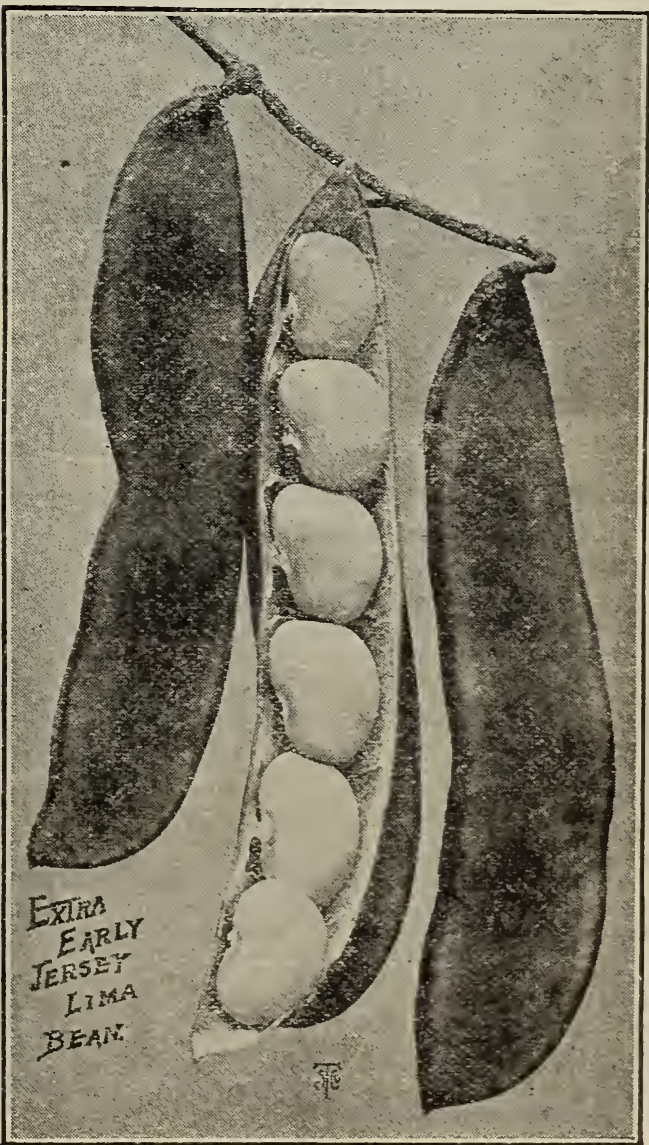




\section{Detroit Dark Red Beet.}

The Best Beet For Table Use.

One of the finest varieties for the market and home garden. Valuable for its remarkable uniformity of size. It is uniformly smooth and has comparatively small tops. Flesh fine grained, crisp and tender. Is desirable for eitler early or late crop. Skın blood red; flesh dark red, zoned with a lighter shade. (See illustration made from a photograph.) Price, $1 / 2$ oz. pkt. Io cts; $0 z . I_{5} \mathrm{cts} ; 1 / 4 \mathrm{lb} .25 \mathrm{cts} ; 1 \mathrm{~b} .70 \mathrm{cts}$. Express, $1 \mathrm{~b} .60 \mathrm{cts}$.

\section{Giant Pascal Celery.}

Unexcelled in Flavor and Keeping Qualities.

This superb Celery partakes of the sweet, nutty fla vor of the Golden Self-Blanching, of which it is ar offspring; but it is a stronger grower, also larger, and producing perfectly blanched stalks. We do not think the color of any Celery is better described by the word "Ivory" than this one. The stalks are thick and heavy, fewer in number than in other kinds, but making full weight by reason of width and thickness. They

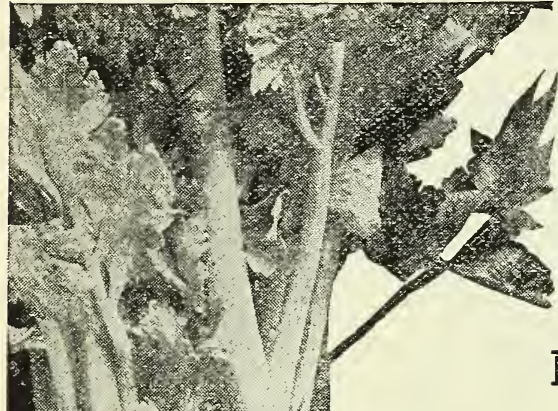
are solid a $\mathrm{n}$ stringless, and almost as brit. tle as glass. It is unequaled in rich nutty $\mathrm{fla}$ vor. A fin e $\mathrm{k}$ e e $\mathrm{p}$ e $\mathrm{r}$ and shipper, retainor and $f r c s h$ ness. Pkt. $5 \mathrm{c}$; $1 / 2$ oz. Io cts; oz $20 \mathrm{cts} ; 1 / 4 \mathrm{lb} .60$ postpaid.

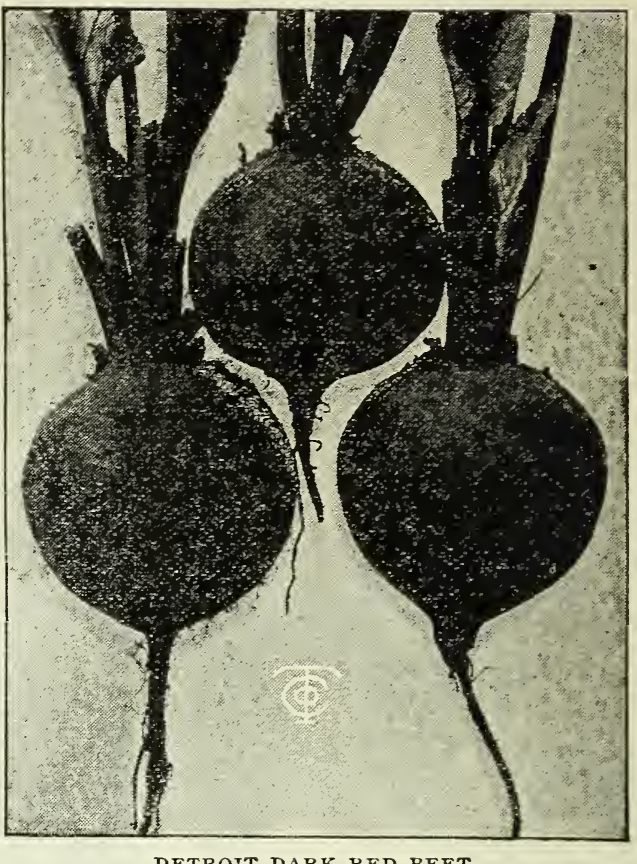

\section{Early Jersey Wakefield Cabbage.}

The Best First Early Variety.

There is more Wakefield Cabbage sold annually than of any other two or three va. rieties combined; and if we include Wakefield that are sold under other names, the proportion would be much greater. This fact proves beyond question that it is the best. It forms fine solid heads of good size, conical in shape, with few outer leaves, hence can be planted close together. We offer the very earliest strain of this standard variety; grown only from select heads. On our trial grounds every plant produced large, conical, perfect heads. Price, postpaid, packet $5 \mathrm{cts} ; 1 / 2$ ounce 15 cts; ounce $25 \mathrm{cts} ; 1 / 4 \mathrm{lb} .75 \mathrm{cts}$; pound $\$ 2.25$. By express, pound $\$ 2.15$.

\section{Danish Ball-Head Cabbage.}

Hard as a Rock. Heavy as Lead.

The Danish Ball-Head Cabbage, which has also been sold under the names Hollander, Solid Emperor, \& $c_{\text {. }}$, is becoming exceedingly popular. Large quantities are imported annually and sold at much higher prices than our American varieties. By using the best imported seed it can be grown equally as well here, although it requires richer soil and higher cultivation than our American varieties. Heads medium in size, round and extremely solid; being fully one-fourth heavier than any other variety of similar size. In quality it has no equal. It is an excellent keeper. By pulling it up by the roots, trimming off the loose outer leaves and hanging it up in a cool cellar it will keep until spring. Packet ro cts; $1 / 2$ ounce $25 \mathrm{cts} ; 1 / 4$ pound $80 \mathrm{cts}$; pound $\$ 2.50$, postpaid. By express, pound $\$ 2.40$.

\section{Glory of Enkhuizen Cabbage.} Unexcelled for Market Gardeners.

Very Early, Large, Solid; Excellent in Quality.

This is a very early, extremely solid, large and round headed variety. It originated in Holland. Those who have tried it in this country claim it will double the crop of any other early variety. Where once known it rapidly gains in popularity with the market gardeners and home growers. It is very dwarf and compact in habit of growth, allowing very close planting. Heads fine globular, with few loose outside leaves. Size ideal for early marketing. Uniform and sure heading.

When planted by the side of other extra early varieties, under the same conditions, Glory of Enkhuizen produces heads of marketable size, five to six days earlier and in size nearly double that of the other varieties. It also proved more solid and kept in fine condition much longer. It is extremely tender and fine grained, and excels in flavor all known early varieties. An extra good cropper on account of large size and close planting. All who have tried it report favorably. Price, per packet. Io cents; $1 / 2$ ounce 20 cents; ounce 30 cents; $1 / 4$ pound So cents; pound $\$ 2.50$. By express, pound $\$ 2.40$.

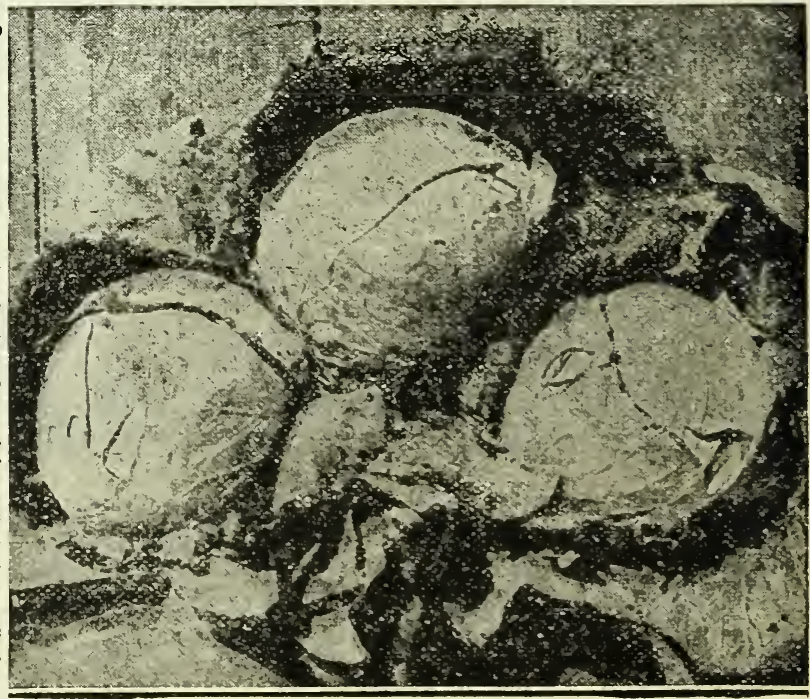

GLORY OF ENKHUIZEN CABBAGE. 


\section{Templin's Golden Honey Sweet Corn.}

Very Early. Dwarf Habit. Very Productive. Superior Quality.

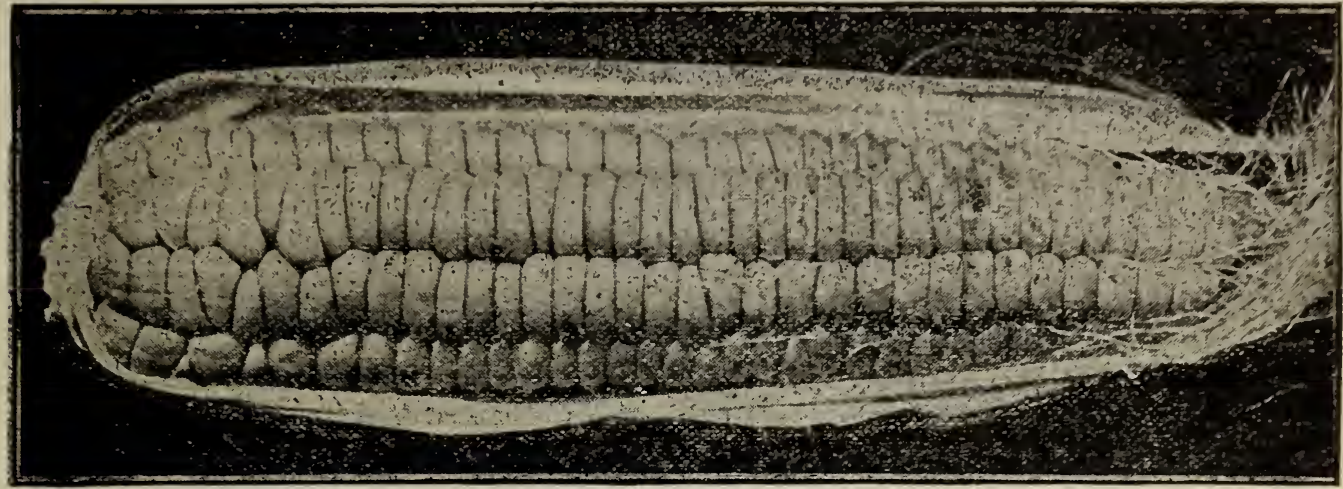

A splendid new variety that excels all others in richness and delicacy of flavor. Its rich creamy color when cooked makes it unusually attractive, and leads to an anticipated richness of flavor that is always better than expected. When young it has the same rich, bright yellow color of field corn, deepening to golden yellow as it ripens. It is not extremely early, but is properly placed among the very early varieties, as it ripens only a few days Jater than Cory. It is of rather dwarf habit, growing only from 4 to 5 feet high. The stalks usually produce two fine ears, sometimes three. The ears are from 5 to 8 inches long, usually 8-rowed; the grains being broad and of good length. Cob small and white. Pkt. I0 cts; $1 / 2$ pt. 15 cts; pt. 25 cts; qt. 45 cts. By express, qt. 35 cts.

\section{Davis' Perfect.Cucumber}

Has No Equal For Slicing.

Ideal Shape. Very Productive. Almost Seedless.

This splendid new variety seems to possess more real points of merit than any other ever introduced. We befieve that in Davis' Perfect we are offering our patrons the best Cucumber ever offered. The sum total of the claims made for it are that by its use gardeners can produce out-of-door encumbers that will sell in the market for hot-house or forcing varieties. These, as is well known, always brings fancy prices.

This variety was introduced by a veteran grower and is the result of careful selection and breeding of extra long, white spine type. It is a wery vigorous grower, withstanding blight and disease better than most varieties. The fruits average from to to 12 inches long, some measuring 16 inches. In shape they are slim, slightly pointed at each end. Color, dark green, which they retain antil nearly ripe when they turn white.

They are unexcelled for both outdoor and forcing. The fruits are tender, brittle, and of exceptionally fine flavor. Our seed was produced from select stock. $1 / 4$ ounce pkt., sufficient to plant 30 hills, io cents; onnce 20 cents; $1 / 4$ pound 50 cents; pound $\$ 1.25$.

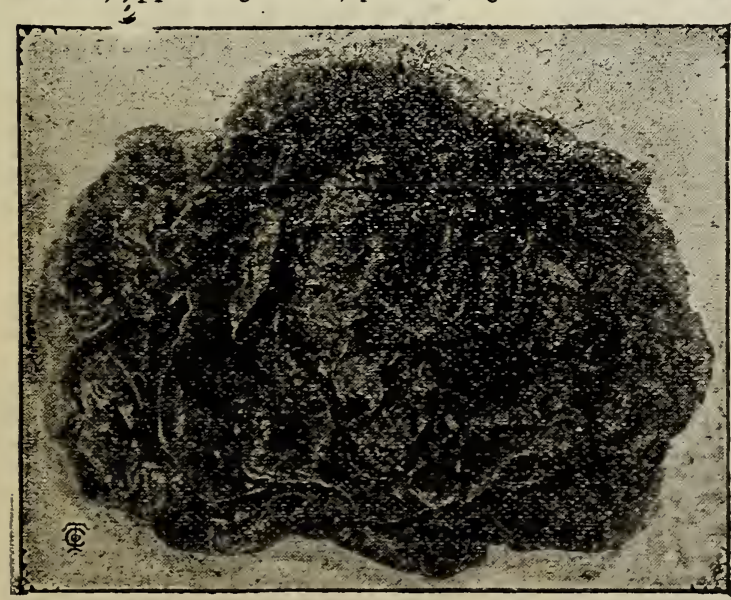

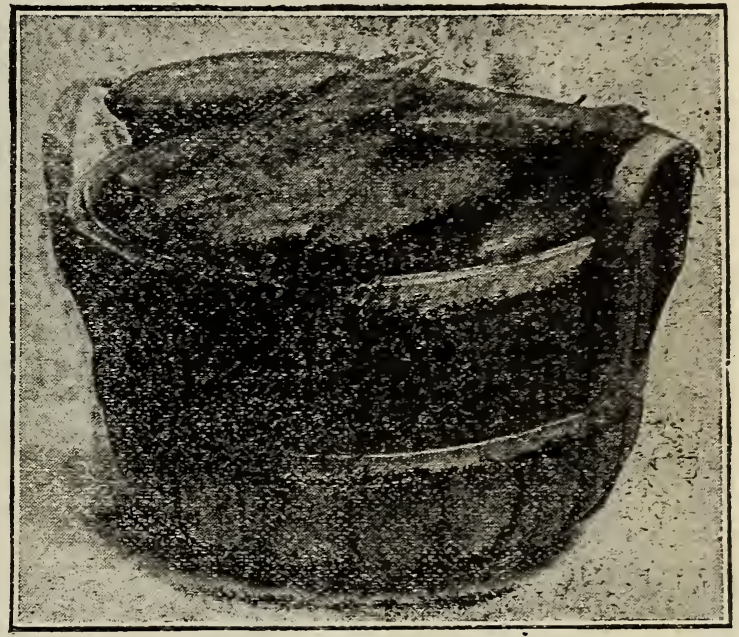

DAVIS' PERFECT CUCUMBER.

\section{New Lettuce, May King.}

The Most Popular Lettuce Known,

Very Early. Fine Globular Heads. Flavor Unexcellẹd.

Truly a remarkable new variety. It has proved 'val. uable as an early out-door Lettuce for growing in cold frames. It is not in the least effected by the cold, wet weather; grows very quickly, and produces, even on poor soil, splendid globular heads, which are ready for use ro to I4 days in advance of any other variety and stands a long time before running to seed. The leaves are of a greenish yellow, with light brown tinge; inside of leaves are golden yellow. The illustration shows habit of growth. In point of flavor it is unexcelled by any other sort. It is sure to command a quick sale and become very popular. We can heartily recommend this splendid Lettuce to our many patrons.

Price per packet of one-sixth ounce, rocents; ounce 25 cents; $1 / 4$ pound 60 cents; pound $\$ 1.50$. By express, not prepaid, pound $\$ 1.40$.

\section{Several Splendid New Vegetables.}

Ifest year, we offered to our patrons on a special separate sheet, five of the latest novelties, of sterling merit. We sent these out to each of our patrons, asking that they give them a careful trial and report the results. We adapted this method to prove whether or not the varieties are distinct, and worthy to place in our catalogue this season. The reports are satisfactory. They will be found more fully illustrated and described on page 12. 
Produced in the great Rocky Ford region. Pronounced by experts the most delicious in flavor, and unequaled for market.

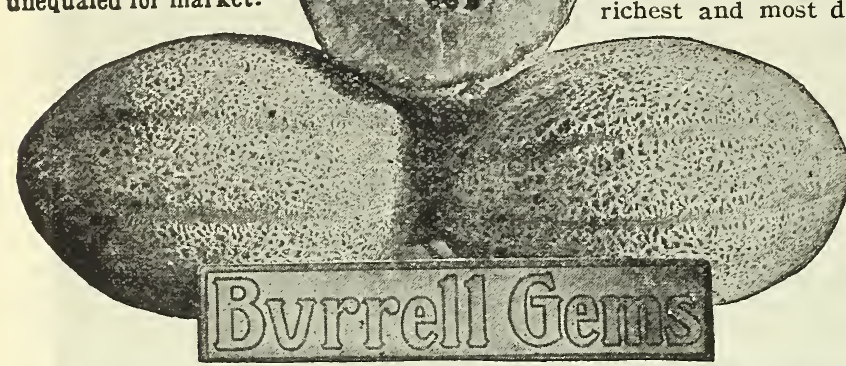

\section{Burrell’s Gem Musk Melon.}

Large Size; Orange Flesh; Unequaled in Flavor.

A superb new variety, introduced by Mr. Burrell, of Rocky Ford fame: a decided inprovement on that variety, being of the same fame: a dhe elicious flavor, seeming to almost melt in the mouth, and jet so solid as to be a most excellent shipper. Closely netted, thin rind; flesh very thick, seed cavity small. Melons averare about 6 inches long, $4 \frac{1}{2}$ inches in diameter and weigh $2 \frac{1}{4}$ pounds. In the markets of New York, St. Louis, Chicago and elsewhere, they bring 50 to 300 per cent. more than the best Rocky Fords. It is exceedingly productive. Mr. Burrell grew 12 acres for market and sold them at an average of $\$ 500$ per acre. The above facts are sufficient to insure its popularity with market gardeners who have a critical trade; also with home gardeners who want melons of exceptional high quality. Packet 10 cts; oz. $30 \mathrm{cts} ; 1 / 4 \mathrm{lb}$. $\$ 1.00 ; 1 \mathrm{~b} . \$ 3.25$.

\section{* New Watermelon, Halbert's Honey.}

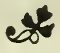

Large Size; Very Productive; Thin Rind; Tender and Crisp; Unexcelled in Richness of Flavor.

This fine new variety is fully squal to $t \mathrm{~h}$ e Kleckley Jweet in superb, luscious flavor. It is considered the finest of all Watermelon s for the home. garden and to supply the choice t.ra de in local mar kets. Fruits regular in outline, even in size, rich, glossy dark green. The fruits average 18 to 20 inches long.

It is essentially a home

melon for your

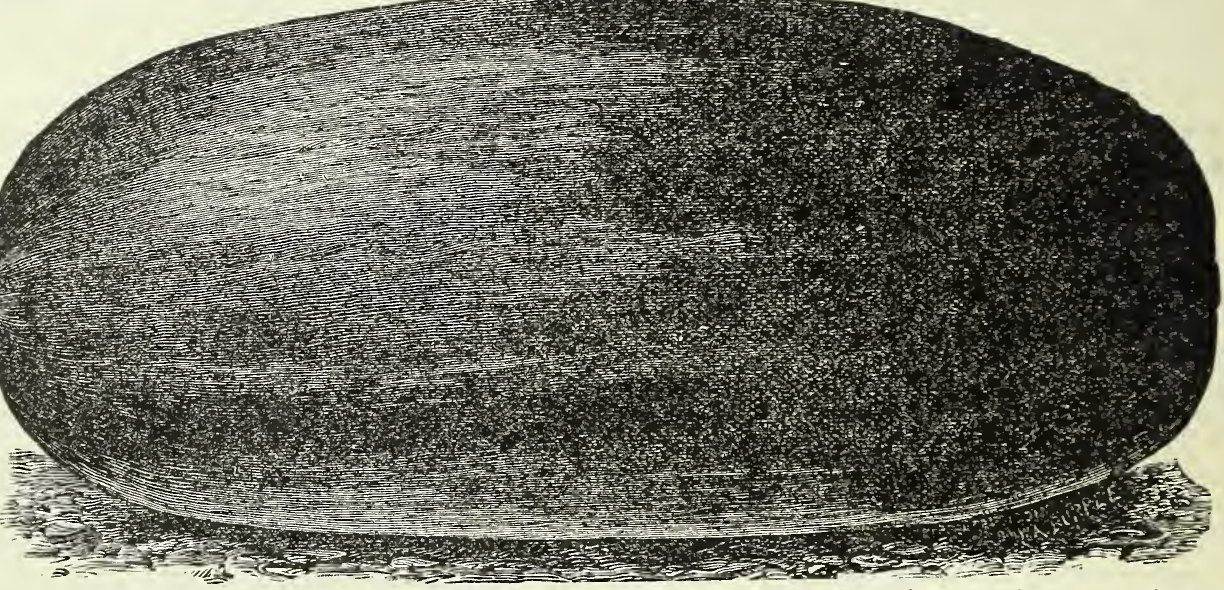
own use or a near points. A

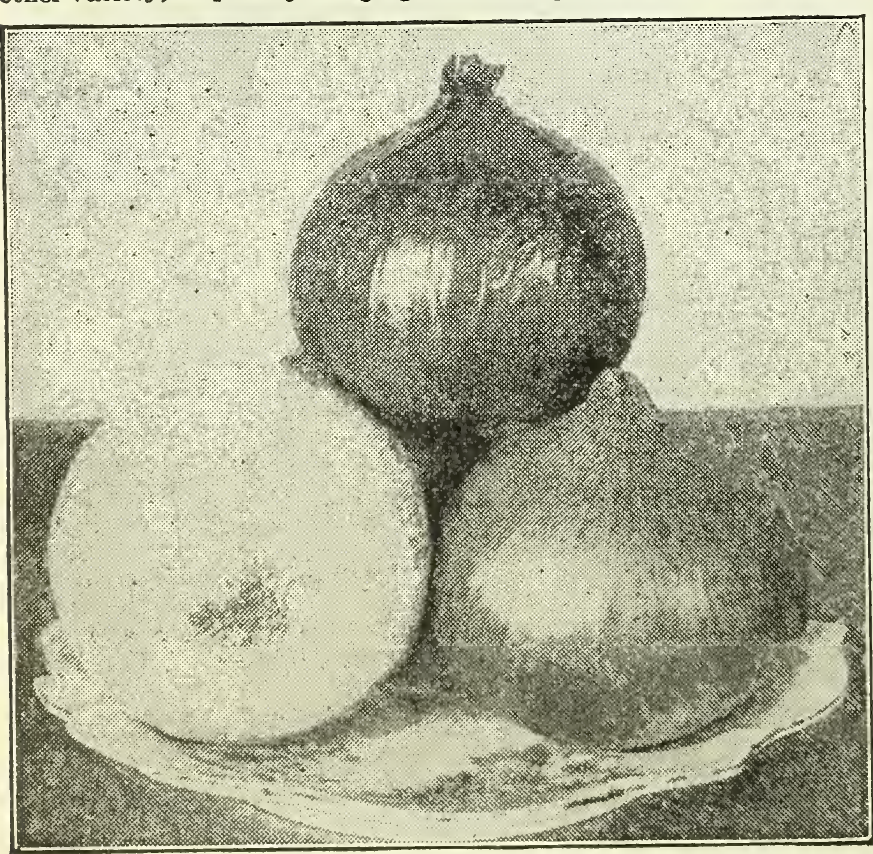

SOUTHPORT GLOBE ONIONS-RED, WHITE, AND YELLOW.

\section{Southport Onions.}

The Greatest Money Makers.

This is a strain of Globe Onions that has increased wonderfully in public favor during the last few years. In almost all markets they will invariably bring top prices. They fully equal in yield the very best strains of other varieties, and are not only handsome in appearance but remarkable in solidity and keeping quality.

RED. One of the most handsome globeshaped Onions, having a deep red skin similar to Weathersfield, but differing in shape, being almost a perfect globe. Matures with Weathersfield, produces large crops, and is one of the best keepers. Fine grained; mild flavor. Pkt. 10 cts; oz. 25 cts; $1 / 4$ 1b. 75 cts; 1b. $\$ 2.25$. Exp. 1b. $\$ 2.15$.

WHITE. Very beautiful and symmetrical in form. Skin and flesh pure silvery white. Flesh very firm, fine grained, and of mild flavor; an excellent keeper. Its uniform size, globular form, and clear silvery-white skin makes it one of the most profitable Onions for the market gardener. Pkt. $10 \mathrm{cts}$; ounce $30 \mathrm{cts}$; $1 / 4$ pound $\$ 1.00$ pound $\$ 3.25$. By express, pound $\$ 3.15$.

YELLOW. Fine globe-shaped Onion, larger, lighter colored and entirely distinct from the Danvers type, Large and handsome; skin light straw color; flesh white, fine-grained, mild. Good seller: heavy croper: fine keeper. Plit. 10c: oz. 25c; 1/4 lb. $70 \mathrm{c} ; 1 \mathrm{~b} . \$ 2.00$. By express, $1 \mathrm{~b} . \$ 1.90$. 


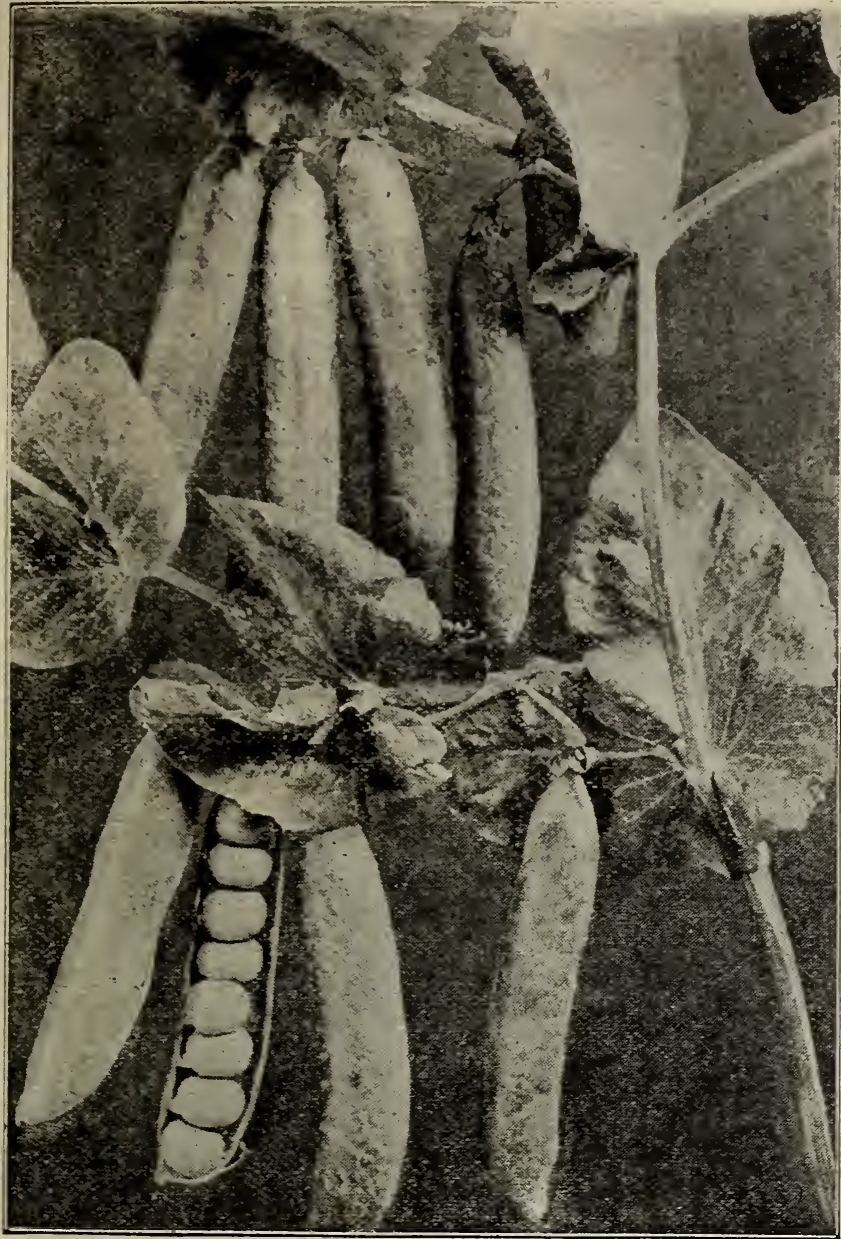

THOMAS LAXTON PEAS.

\section{New Chinese Giant Pepper.}

The Largest Mild Pepper.

Plants Vigorous and Stocky. Produces Enormous Crops.

This variety is noted for its enormous size, magnificent a ppearance and great productiveness. Its fruits are double the size of Ruby King. It is the largest and finest mild or sweet Pepper. The plants a re of vigorous growth and stocks habit, seldom more than 2 feet high and well branched. Their sturdy growth enables them to carry and mature their enormous crop of monstrous fruits. They a re of uniformly large size, and the flesh is unusually mild; it makes an excellent salad when sliced and served with Tomatoes. Fruits a re 4 to 5 inches broad at the top, divided into four or more ridges. We can heartily recommend this variety. Pkt. of 300 seeds, 10 cents; ounce 60 cents; $1 / 4$ pound $\$ 1.60$.

\section{White Icicle Radish.}

Long, Slender, Crisp, Tender, Mild, Purest White, Attractive. Unexcelled as a Money Maker.

A distinct new variety, producing long, slender, pure white, transparent Radishes. Much earlier than an 5 other long white variety, while the roots continue brittle, crisp and mild for a long time. From one planting tender radishes may be had for the table for a longer yeriod than from any other variet 5 . A desirable variety for the home garden, and market gardeners find it a great mones maker. It is ready for use in 25 to 30 dass after planting. Admirably adapted for forcing or successive plantings in the open ground, The most attractive variety when bunched for market; alway's bring top notch prices. Price, packet 5 cents; ounce 15 cts: $1 / 4$ pound $40 \mathrm{cts}$; pound $\$ 1.25$. By express, pound $\$ 1.15$.

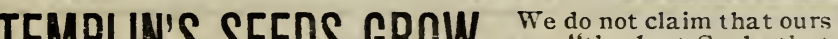
TEMPLINS SEEOS GROW. our patrons say. "THERE ARE NONE BETTER." Every year, before the trade begins, we test every variety carefully to be sure they will grow. We can give per cent. of germination of each variety. Could aiso give thousands of Testimonials from pleased customers.

\section{Thomas Laxton Pea}

A New Wrinkled Pea.

Unexcelled in Vigor and Procuctiveness.

This is a new Wrinkled Pea of exceptional merit. It is very carly: almost as early as the Extra Early, types. It is indeed astonishing that Pcas with such fine larke pods should be so early to mature. 'The vines grow about 3 ect high, much like those of Gradus, but are more hardy and much more productive. The pods are large, long, with square ends: similar to but larger, longer amd more hand some than those of Champion of England, and fully as uniformly witl filled. The green peas are very arge, fine colored, and unsurpassed in quality. The accom panying illustration was made from a photograph and shows the shape and well filled pods perfectly. We are certain that this plendid new Pea needs only to be known to become one of the most popular sorts for the home and market gardener. It is certainly one of the very best Early Peas ever introduced.

Price, 2-ounce packet, 10 cents: pint $30 \mathrm{cts:}$ quart $50 \mathrm{cts}$. By express, qt. $40 \mathrm{cts} ; \mathrm{pk}$. $\$ 2.25$.

\section{Alderman Peas.}

Fine, New, Second-Early.

Unsurpassed for Market Gardeners.

This is, without doubt. one of the finest large podded summer varieties. It is second-early or medium variets, growing about 4 feet high, robust and vigorous in habit, and a wonderfully prolific bearer. The pods are frequently nearly six inches in length and closely packed with 8 to 10 magnificent large peas, having a rich sugary flavor. An especially valuable varie: $y$ for the market gardener, as it grows remarkably true to type. It is unexcelled in productiveness. Considering very luxuriant growth, prolific bearing, large size, superior lavor and quality, it possesses a combination excellencies rarely found in one variety.

Packet $10 \mathrm{cts}$ : pint $30 \mathrm{cts}$ : quart $50 \mathrm{cts}$. By express, quart 40 cents; peck $\$ 2.25$,

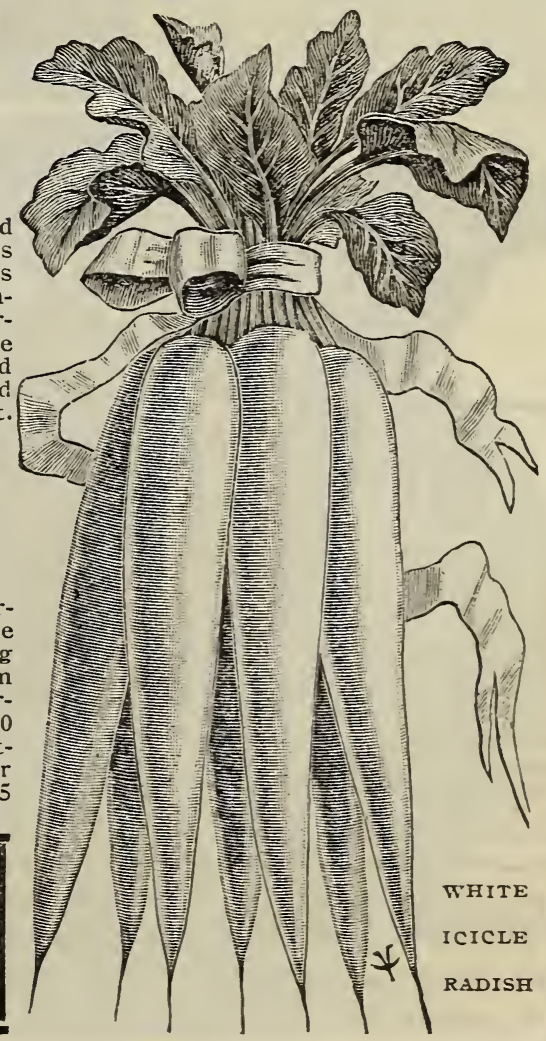




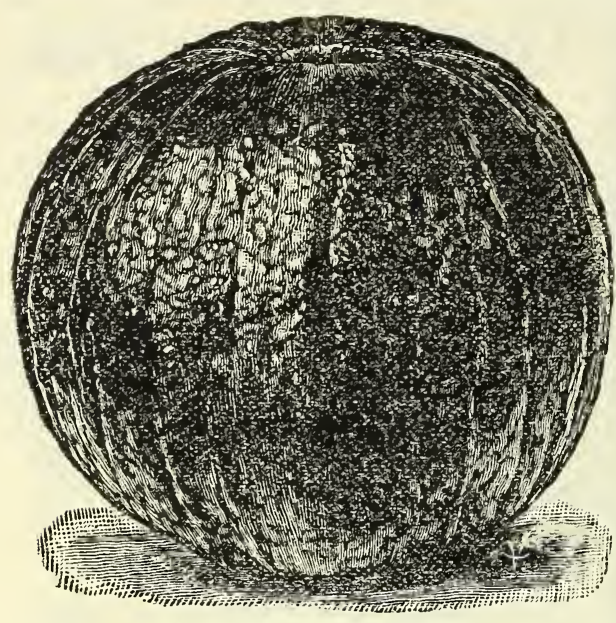

\title{
Chinese Celestial Radish.
}

Unexcelled in Size and Quality.

This is an old variety of the greatest merit for winter use. It is of Chinese origin, but is thoroughl 5 ad apted to our soil and climatic conditions. They grow 10 to 15 inches long, 3 to 4 inches in diameter. Pure ivory-white, and contrary to other very large varieties, the flesh is always crisp, juicy and of mild flavor: seldom hollow and pithy. It is the finest in quality and appearance of all the large white Radishes. Continued selection has brought it to perfect shape and finest quality. Price, per packet of $1 / 4 \mathrm{oz}$., 10 cents; $0 z 20$ cents; $1 / 4$ lb. 35 cents. ib. 85 cents.

\section{Small Sugar Pumpkin.}

\author{
Unsurpassed for Pies.
}

This is neither a novelty or a new variety. Our only reason for offering it here is that it is positively the best Pumpkin grown. It is sold under various names, as Sweet Pumpkin, Yankee Pie, New England Pumpkin, \&c. It is the variety from which the celebrated Yankee pumpkin pie is made. It is small, being only about ten inches in diameter, but of the highest quality. It has a deep orange-sellow skin, and very fine grained flesh; is handsome and an excellent keeper. The average weight is about five ounds; is quite prolific, a sure cropper and excellent for marketing as it is of convenient size. Cannot be excelled as i) table Pumpkin. Price, pkt, of $1 / 2$ oz., sufficient for 20 to 25 hills, 10 cts.; $0 z .15$ cts.; $1 / 41 \mathrm{lb} .30 \mathrm{cts}$; $1 \mathrm{~b}$. 75 cts.

\section{The Famous New Squash, "Delicious."}

Unequalled in Fineness, Dryness and Richness of Flavor.

This is the latest introduction of tregory, the Squash man. He zays: "In quality it surpasses avery one of the five varieties I have introduced-The Hubbard, Chestsut, Marblehead, Butman and Warren." It is a fall and winter Squash, being excellent at all seasons, but like the Hubbard does not acquire its best quality until vinter. Color, dark green with xcassionally a blue specimen. A vrages about the size of the Hubbard, but vary somewhat in shape. $t$ is unequaled in fineness of grain, iryness when baked, and richness ff flavor, and retains its excellent qualities during the entire winter. Price, per pkt. of $1 / 2 \mathrm{oz}$, sufficient or 15 to 20 hills, $10 \mathrm{cts}$.; oz, $20 \mathrm{cts}$. 1b. 50 cts.; 1b. $\$ 1.40$.
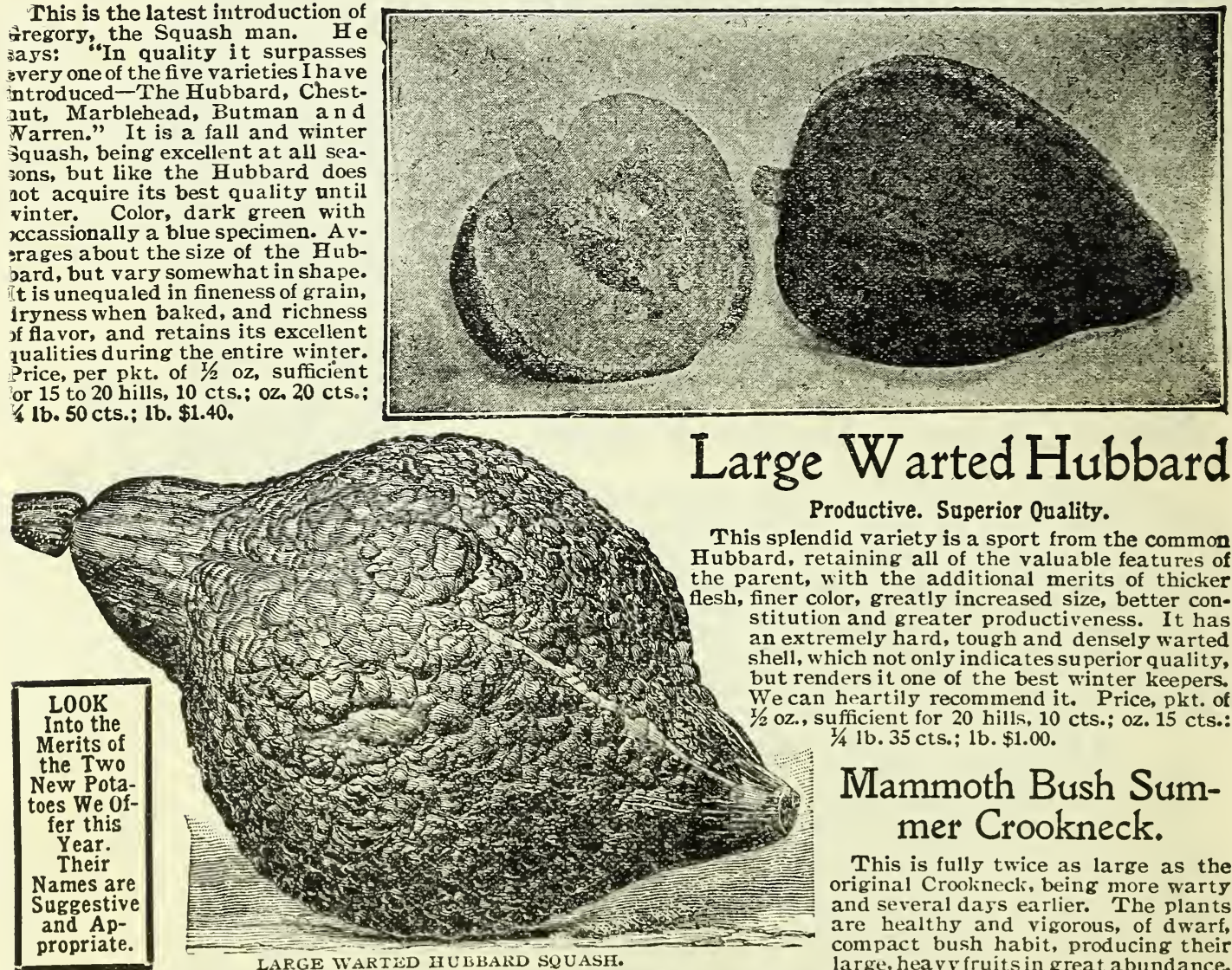

Warted Hubbard

Productive. Superior Quality.

is splendid variety is a sport from the common rd, retaining all of the valuable features of , with the additional merits of thicker

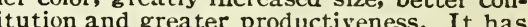
extremely hard, tough and densely warted ell, which not only indica tes su perior quality, the best winter keepers. heartily recommend it. Price, pkt. of $1 / 4$ lb. 35 cts.; 1b. $\$ 1.00$

\section{Mammoth Bush Sum- mer Crookneck.}

This is fully twice as large as the original Crookneck, being more warty and several dass earlier. The plants are healthy and vigorous, of dwarf, compact bush habit, producing their large, heavy fruits in great abundance. Shin bright zellow: flesh yellow; cooks quite ary and possesses a most agreeable flavor. This is, in fact, the most highly esteemed of all the early summer varieties. A profitable variety to grow for the early market. We particularly recommend our selected strain to both home and marliet gardeners. Price, per $1 / 2$ ounce, sufficient for 20 to 25 hills, 10 cents; ounce 15 cents; 1/4 pound 30 cents; pound 90 cents.

CDER|A DRIRFC We gladly quote Special prices to Market Gardeners and others who JPEIAL RIUEJ. grow vegetables for the market, and who use seeds in larger quantities than quoted herein. Only larger quantities than offered herein will entitle you to lower quotations. Our seeds are equal to the best. 


\section{Livingston's "Hummer" Tomato.}

A most excellent Tomato. It is quite distinct in several important points. For the market and home garden the Hummer cannot be beaten. It is fine for growing on stakes or trillises. Color of fruits bright scarlet; flesh rich crimson-scarlet, and the finest quality. In size, not so large as The Stone, but a most excellent variety for canning, as a large per cent. of the fruit can be put in the can whole. Fruits firm, solid, free from cracks, always smooth, of desirabe size. It is a healthy, vig. orous grower, of medium $\mathrm{s}$ i $z$ e d vines; a great producer of beautiful frust, borne in clusters. If picked when jost turning to ripen, it will carry to distant markets in excellent condition, color up nicely a n d meet ready sale. It being quite an early. Tomato, is especially desirable also for canners' use in those latitudes where the crop must be produced in a short period of time. Price, pkt. Io cts; oz. 35 cts; $1 / 4$ lb. \$1.10; lb. \$4.00.
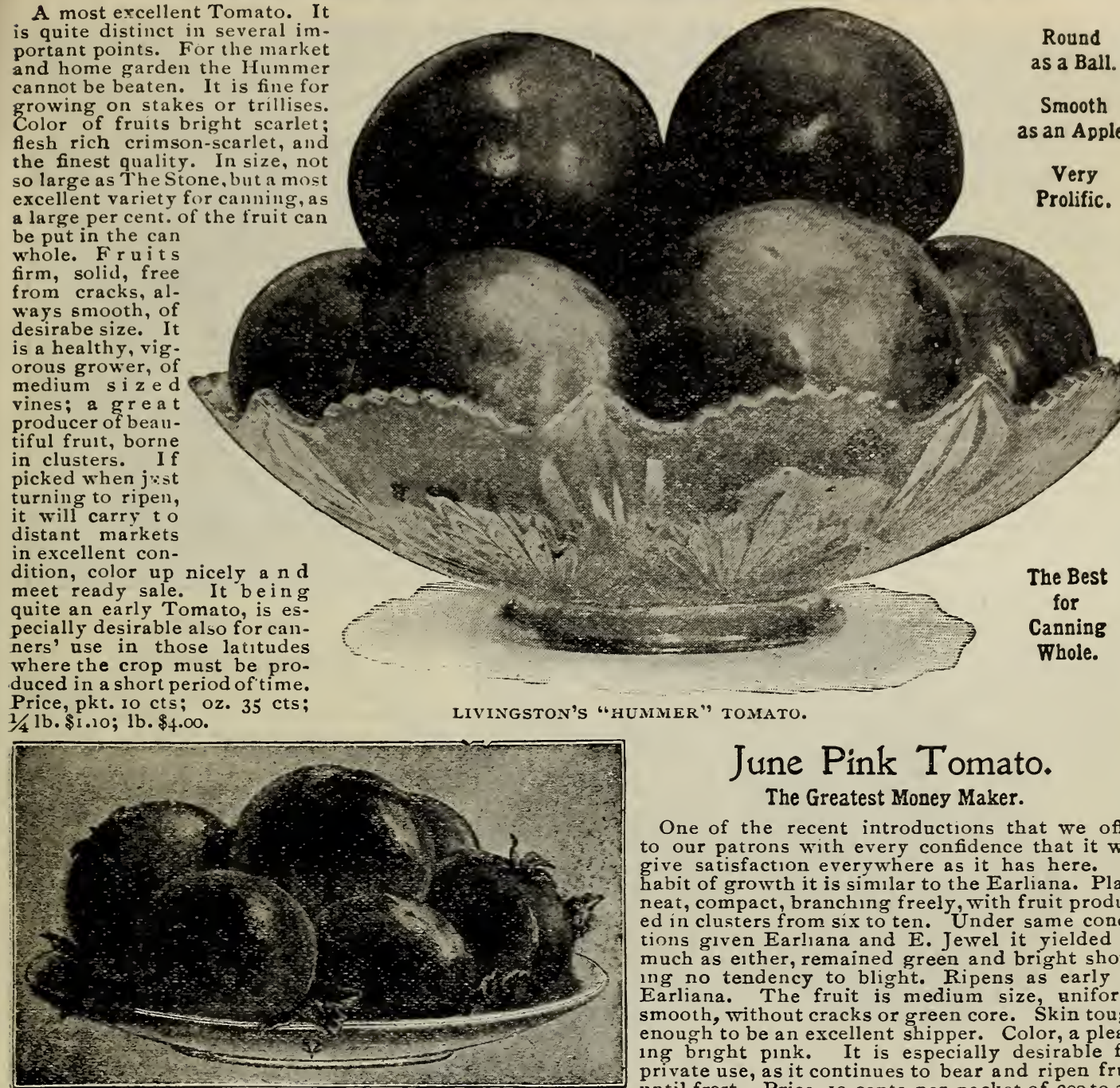

JUNE PINK TOMATO.

\section{Livingston's Magnus Tomato.}

Excellent for Main Crop. The Finest Variety for Growing on Stakes.

A very distinct and valuable variety and is indeed one of the most handsome varieties in cultivation. Magnus is unsurpassed in the quality and in the production of fine, large, smooth fruits. It matures so quickly that it takes rank for early market purposes. The form is perfect, uniform, large and attractive. Flesh very firm. A robust grower with short joints, settıng its chusters close together. A very heavy and continuous cropper; ripens evenly, does not crack, and the flavor is all that could be desired. One of the greatest money makers known. Price per pkt. of 200 to 300 seeds, Io cts; oz. 25 cts; $1 / 4$ lb. 70 cts; $1 \mathrm{~b} . \$ 2.25$.

\section{The "Templin Ideal."}

"To do an honorable business; to be prompts to be careful for your interests as well as our own; to be content with small profits; to send yous pure seeds; to answer all inquiries; to correct all errors promptly; to merit your kind words; in short, to be worthy of your patronage."

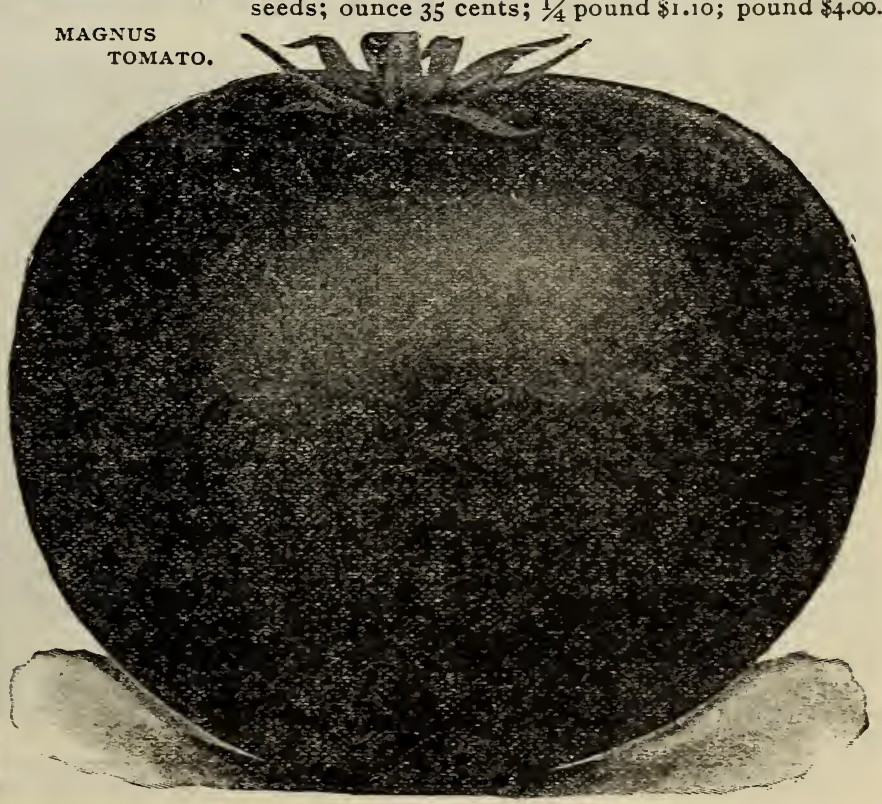

\section{June Pink Tomato.}

The Greatest Money Maker.

One of the recent introductions that we offer to our patrons with every confidence that it will give satisfaction everywhere as it has here. In habit of growth it is similar to the Earliana. Plant neat, compact, branching freely, with fruit produced in clusters from six to ten. Under same conditions given Earliana and E. Jewel it yielded as much as either, remained green and bright showing no tendency to blight. Ripens as early as Earliana. The fruit is medium size, uniform, smooth, without cracks or green core. Skin tough enough to be an excellent shipper. Color, a pleasing bright pink. It is especially desirable for private use, as it continues to bear and ripen fruit until frost. Price, Io cents per packet of 200 to 300 seeds; ounce 35 cents; $1 / 4$ pound $\$ 1.10$; pound $\$ 4.00$.

The Bes

Canning

Whole.

Smooth

Very

Prolific. 


\section{Three of Our 1909 Novelties.}

Others will be Found on Pages 2 and 11.

I ast year we offered, on a special little folder, and through our correspondence, five new Vegetable Novelties. We did not have enough seeds of any to warrant offering them in the catalogue. Our patrons were so well pleased with them that we give them space in the catalogue, as worthy of general dissemination.

New Lettuce,

Green Idyl.

This variety we offered first in 1909. There are new Lettuce be. ing introduced every season; each possessing some special merit, but none being meritorious for all seasons and conditions. Some are especially adapted to early out-door culture, some to mid-summer, some for all-seasons, and some for green. house forcing.

Green Idyl is a splendid midseason variety as it possesses wonderful heat-resisting qualities, remaining in fine condition a long time, in the hottest weath$\mathrm{er}$, without going to seed. It is green outside and yellow in the centre. It is one of the largest and most solid Head Lettuces, and 1ts quality is of the best. Pkt. 10 cents; ounce is cents.

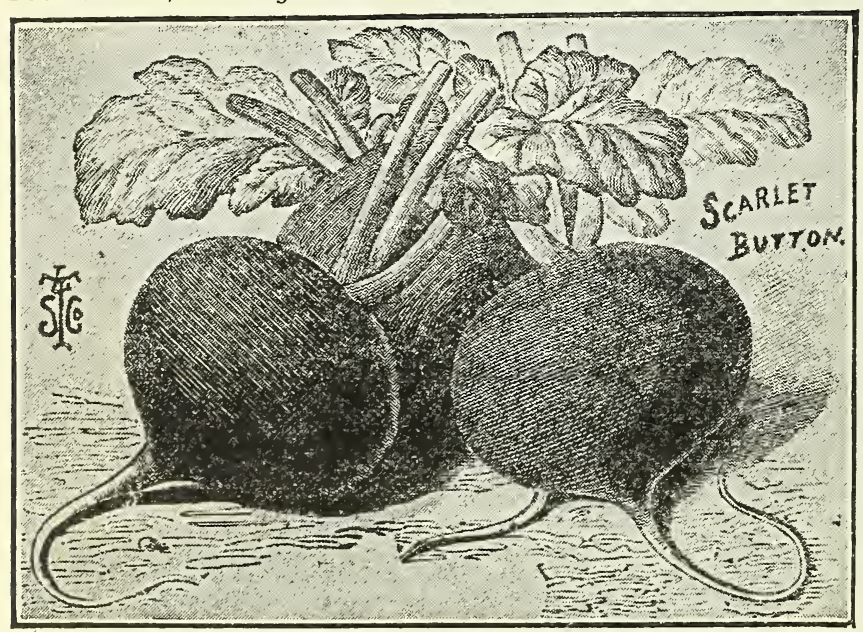

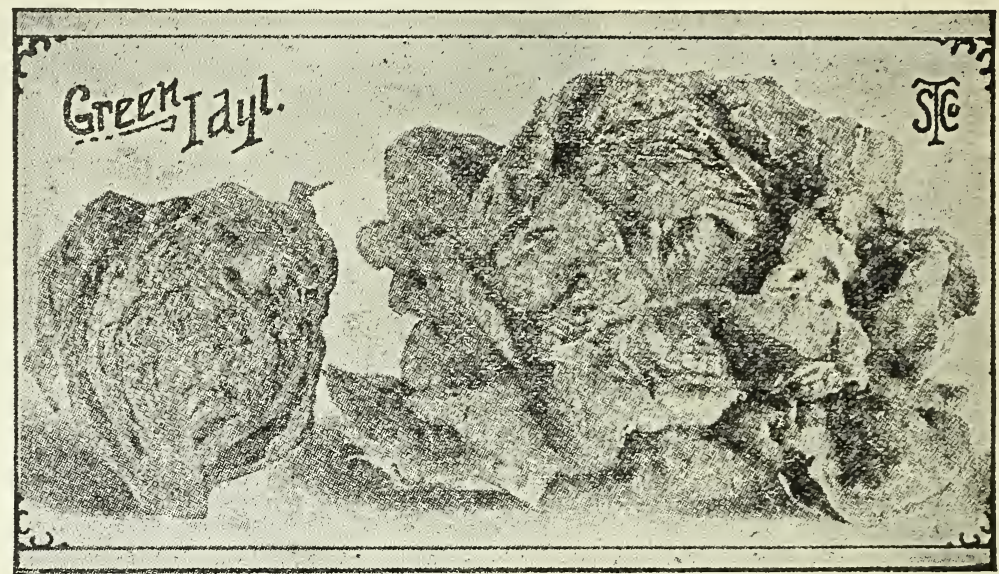

New Radish, Scarlet Button.

This variety we first offered last year as one of our novelties. Our patrons were so highly pleased with it that we think it worthy of general introduction. "Scarlet Button" is very early. If you wish to have the first and the finest red Radishes in your neighborhood next spring order Scarlet Button. In fovorable weather and good soil it will mature in from IS to 20 days from the sowing of the seed. The skin is a bright scarlet; flesh pure white, and always crisp, tender, mild and sweet. It has small tops and is adapted to both early out-door culture and for forcing under glass. It is extensively used by market gardeners and truckers who value it highly because of its quick growth, globular form, and bright color. We can heartily recommend it to our patrons. Pkt. 5 cts; ounce ro cts.

See the new Giant Japanese Radish, "Sakurajima" offered on page 2 . We give a packet free with a 50 cent order for seeds in packets.

\section{New Swiss Chard, "Lucullus."}

This is a splendid new variety. In the old type of Swiss Chard the leaf portion is smooth, broad, and rounded at the upper end; in the Lucullus they are larger, much longer, and sharply pointed at the top, while the texture is heavily crimpled or savoyed and is very crisp and of better flavor. The plants grow to a height of two to two and a half feet. The stalks are as thick and broad as those of Rhubarb, being heavily ribbed and from ten to twelve inches long below the leaf.

The stalks are delicious when cooked and should be served in the some manner as Asparagus; the leafy portion of the foliage is cooked and served in the same manner as Spinach. The leaves and stalks being served as separate vegetables, afford two distinct dishes from the same plant at one time. Price, ro cents per packet; ounce 15 cents.

"Have planted your seeds for many years and will say they can't be any bet-
ter." F.J. Shimitz, Iowa City.

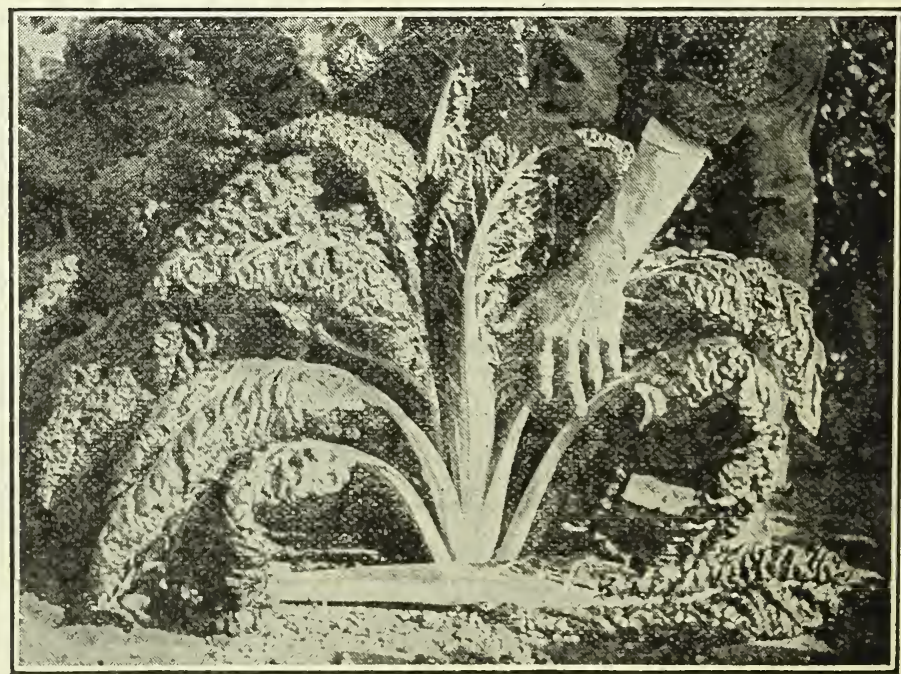




\section{Templin's New Potato, "Dainty-Eye."}

A New Early Potato of the Highest Quality.

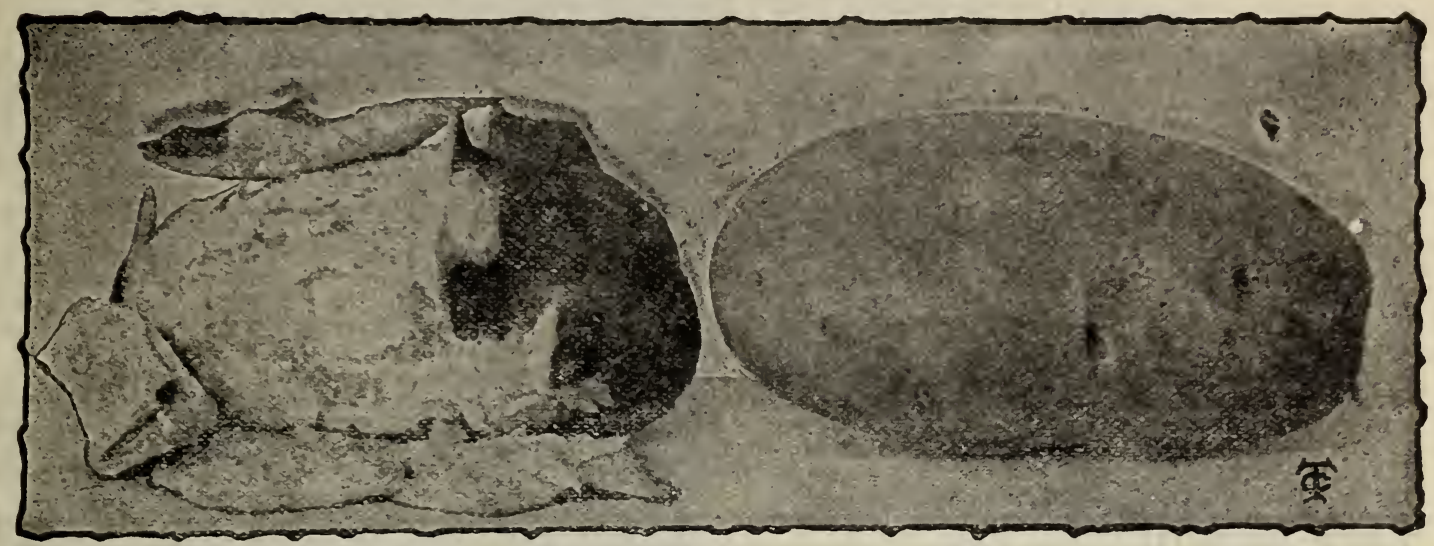

This is the splendid new variety that we first offered in our 1908 catalogue, and for which we offered prizes for a name. There was about five hundred names suggested, by as many of our patrons. All who see the tubers say the name, finally adapted, is very appropriate.

After another season in which we have carefully watched the habit of growth, and in other ways tested its good qualities, we have the same high opinion of the really superior qualities of this new Potato. This has been a tavorable season and it has again made a fine show 11 the vigor, healthfulness and habit of growth.

From the above illustration, which was made from a photograph, you will note the smoothness and ideal shape of the tubers, the shallowness of the eyes-hence the name,-and the excellent cooking quality as shown by the way it bursts open. The flesh is pure white, and when cooked is as fine and white as flour Indeed, the quality is the very highest. Color of tubers light straw, faintly clouded, and eyes pink. It is a splendid gruwer, producing heavy, vigorous stalks with abundant healihy foliage, withstanding diseases as well as ally other variety on our grounds. This season $1 \mathrm{t}$ arain gives evidences of being quite productive, under favorable circumstances. Price, pound 40 cents; 3 pounds for $\$ 1.00$, postpard By express, peck $\$ 1.00 ;$ bushel $\$ 2.50$

\section{Templin's New Potato, "Knoxemall."}

Vigorous, Heaithy and Exceedingly Productive.

This magnificent and excellent new Potato was first brought to our notice a few years ago, by the originator, Mr. Geo. J. Streator, from whom we purchased the entire stock, - a few pounds. This is the fourth year we have been observing its growth and characteristics. We first offered it last season, and are gratified to report that it has proven worthy of the high standard of excellence placed upon it.

As stated, it was grown last season in a 17 -acre field with Carmen, Mark Hanna and other standard varieties; this season it was grown under same circumstances. Our grower, - a Potato expert.-says; "Ihroughout the season it showed great vigor and very healthy growth; it withstood drought well and was almost entirely free from blight; at digging time the tubers were the finest in the field, being larger and smoother than any other; from one acre there was not to exceed ten bushels of unmarketable tubers: in a word, it "Knoxemall." "We have handled a great many Potatoes, but never saw a

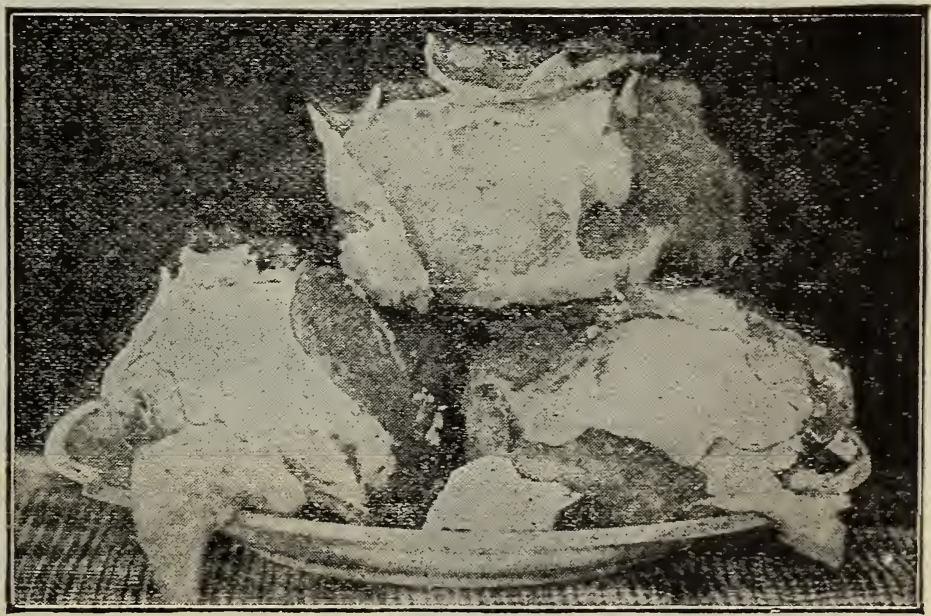
finer, smoother and more uniform lot

of tubers than those delivered the last two seasons. In shape and general characteristics it is somewhat similar to Mark Hanna, but is superior in every point. The tubers are large and ideal in shape; very smooth, with shallow eyes; color, white; flesh white. In cooking qualities it is positively unexcelled; the illustration above shows how nicely it bursts open when cooked; the flesh being very fine and dry and of excellent quality. When once known we believe it will take first rank among the main crop varieties.

We offer this variety with full confidence that it will please our patrons. We believe that in vigor of growth, health of plants, uniformity of size. smoothness of tubers, shallowness of eyes, beauty of appearance, excellent cooking quality and all other points essential to a high grade, all purpose ?otato, it "Knoxemall."

Price, pound 40 cents; 3 pounds for $\$ 1.00$, by mail, postpaid. By express, peck \$1.00; bushel $\$ 2.50$. REMEMBER, THESE TWO VARIETIES OF POTATOES CANNOT BE PURCHASED ELSEWHERE.

Gentlemen: "My order was received promptly, and thank you for the extra packets. You are always liberal in your dealings with us. We have bought seeds from you for years. The first garden we had, in IS95, was from your seeds, and though we have moved to another state, we must still have your Seeds as we have never had a failure since we have been using them."
Gentlemen: "Am glad to acknowledge prompt receipt of my last order for Seeds. Have used your Seeds for the last four years, and can honestly say that in every instance they have proved true to name, and always grow. I never received nicer and cleaner Seeds. Last year our order was rather late, but every. thing gave excellent results. I thank rou a gain for A. D. Jackson, Yilan, 


\section{Select List of Standard Vegetable Seed.}

\section{ALL HAVE BEEN TESTED AND PROVEN WORTHY.}

The average Seed Buyer knows but little about the vast number of varieties that are being offered in Seedsmen's catalogues. There are many new varieties-so called-brought before the innocent seed buyer every season, with their catchy names, pretty illustrations, and glowing descriptions. A few of these are really new, having been produced by careful breeding and selection; but most of them are old, standard varieties with new names. But the buyer in most instances gets his money's worth, for who will say that a packet of Tomato seed, (though an old variety sold under a new name, at 10 or $15 \mathrm{cts}$.) that produces enough Tomatoes for a family for a year, is not worth the price.

SOME FACTS. By a careful study and comparison of five leading Seedsmen's catalogues, including our own, we found an a vera ge of 35 varieties of Beans, 24 varieties of Beets, and 25 varieties of Lettuce. We offer of these respectively 22, 15 and 18 varieties. Yet there are, according to Dr.W. W. Tracy, of Bureau of Plant Industry, U.S. Department of Agriculture; "so2 varieties of Beans offered by American Seedsmen, but there were among them only 104 distinct varietics." There are also "214 varietics of Bects, but every Beet in the trial could be classed under some one of 20 to 25 distinct types." He further states: "585 varicties of Lettuce catalogued, representing not more than 87 distinct types." No wonder the a verage Seed buyer is bewildered when making selections.

In the following pages we give a list of STANDARD VARIETIES: It contains only the "CREAM" of the vast number of varieties that are offered by the Seedsmen of the world. Each has been carefully tested, not only on our own grounds, but on the trial grounds of other Sedsmen, and by the more valuable trials of thousands of the best and most practical Gardeners in the country. Each variety has thus been proven to possess sterling merit. They are produced by the best growers in the world, and under the names we give. There is really not a single variety that will not, under proper conditions, give satistactory results.

NEW VARIETIES. Most of these will be found on interesting to the gardener, because of the possibility of being better adapted to the prevailing soil and climatic conditions than the standard old varieties. For this reason we recommend them to our patrons.

It has been our custom to test all new varieties and novelties; to preserve and disseminate only those that a re really superior to the old varieties in the same class. We do not hesita te to recommend to our patrons all the New Varieties offered on the pages refered to. We know they will give complete satisfaction.
OLD VARIETIES. We would recommend that our patrons depend upon the standard old varieties of known merit for their main crop, and plant only sufficient of the new varieties to give them a fair trial on your soil.

Study to know the varieties that are best suited to your soil, climate and cult:are; then buy the strains that are known to attain the highest degree of perfection on sour soil. Do not buy Seeds of doubtful quality because cheap. The relative difference in their cost may be very small when compared with the possible crop obtainable. We handle only Strictly High Grade Seeds.

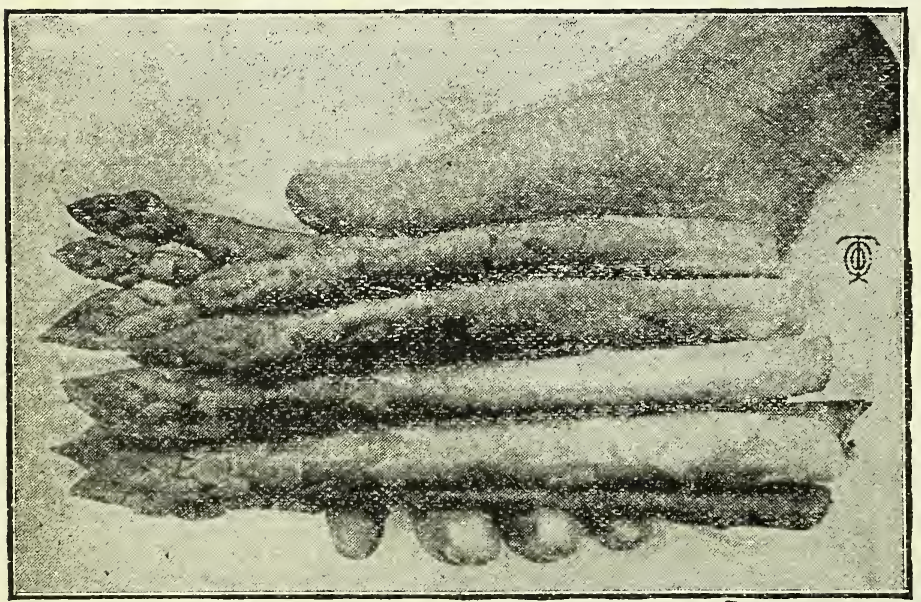

\section{Artichoke.}

CULTURE.-Sow early in seed bed and transplant to four feet each way. Plants set in any good garden soil, with slight protecion, will remain in bearing for many years.

Green Globe. The best known variety. It is cultivated for its edible flower heads which are cooked same as Asparagus. Price, per one ounce packet, 5 cents.

\section{Asparagus Seed.}

CULTURE.-Sow during March or A pr:1, in mellow soil, in a seed bed, and transplant the following spring, 6 inches deep, 12 inches a part, rows 4 feet a part.

Asparagus is the earliest and most delicious product of the garden. It is becoming more popular each sear.

Each packet will contain 1-4 ounce; will produce from 100 to 200 plants.

Five pounds will plant an acre.

Giant Argenteuil. This is the finest Paris Asparagus. Palmetto. Earlier, more even in growth, and a greater The stalks grow to ma moth size, sometimes four ounces yielder than other varieties. It is probably more largely each. Head slightly pointed and the scales are ciose set. grown than any other green variety.

The flavor is very fine. We can heartily recommend it. Conover's Colossal. A variety of the greatest merit.

Price of Asparagus Seed, packet $5 \mathrm{cts}$; ounce $10 \mathrm{cts}$; $1 / 4$ pound $20 \mathrm{cts}$; pound $60 \mathrm{cts}$. By express, pound $50 \mathrm{cts}$.

\section{Asparagus Roots.}

A saving of one to two years is effected by planting roots instead of seeds. From one-year-old roots a fair cutting may be had in two years from planting. From twoyear-old roots cutting may begin the year following planting. Asparagus is a gross feeder, and the plant food should be given every year. Each fall the bed should be heavily manured, and well cultivated in during early spring. Our book, "The Family Garden" gives detailed instructions for planting, cultivating and marketing.

One-Year-0ld Roots. We offer fine roots of Conover's Colossal and Palmetto. Price, postpaid, 12 for $20 \mathrm{cts.}$; 25 for $35 \mathrm{cts}$.: 50 for $60 \mathrm{cts}$, ; 100 for $\$ 1.00$. By express,

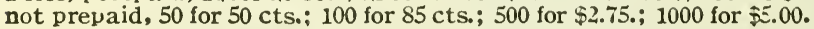

Two-Year-0ld Rcots. These are fine plants. Under proper culture will give a fair cutting the second year after planting. Price, postpaid, 12 for $25 \mathrm{cts}$.; 25 for $40 \mathrm{cts}$. By express, not prepaid, 50 for 60 cts.; 100 for $90 \mathrm{cts}$.; 500 for $\$ 3.50 ; 1000$ for $\$ 6.00$.

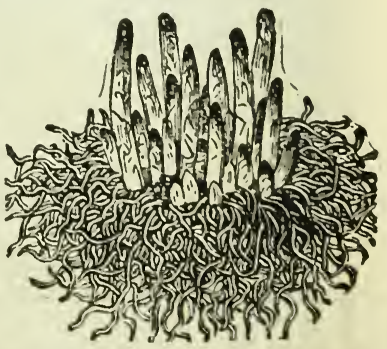

SUCCESS OR FAILURE? That depends largely upno the quality of the Seeds you plant. Real quality in any SUCES Strain of Seeds can only be secured by growers of experience, who are untiring and painstaking in "rogueing" and "selecting" to bring their strains to the highest degree of perfection. The difference in cost to the Gardener may be only a few cents per pound, yet the difference between the crops produced is usually the difference between success and failure. Our Customers say concerning Templin's Seeds "There are none better." 


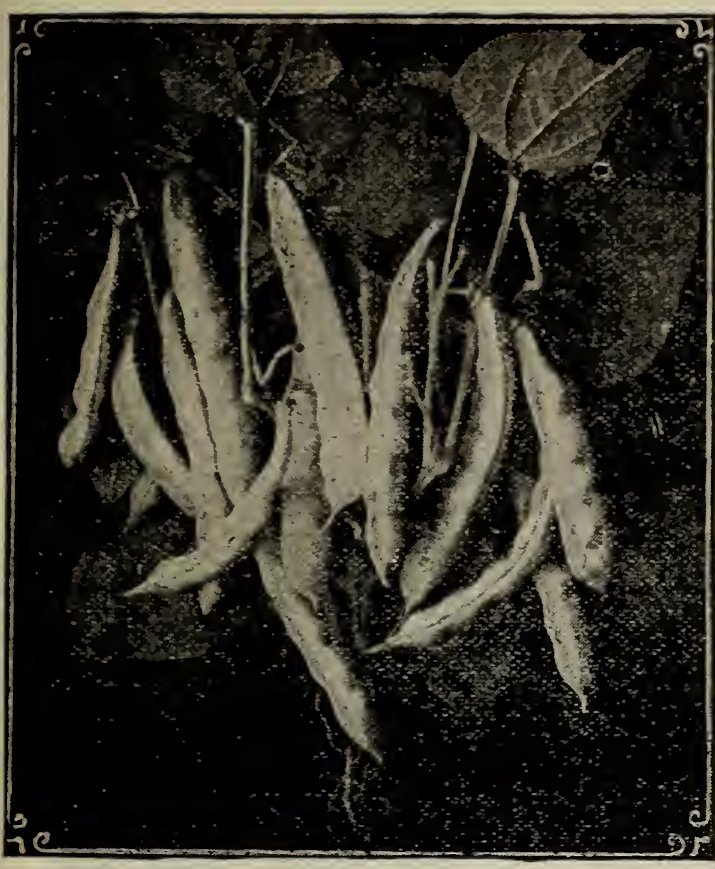

LOW'S CHAMPION WAX.

\section{"Bountiful" Bush Bean.}

Remarkably handsome and possessing superior merit. It is very hardy, practically rust and mildew proof. Extremely early, very prolific. The rich green pods are of immense size, thick, broad, extra long and uniform shape. Quality of the highest; melting, tender. Pods stringless, and retain brittleness longer than other varieties. Excellent when shelled. Unrivaled for home and truck garden. (See cut opposite.) Price, pkt. 5 cents; $1 / 2$ pint 20 cents; pint 30 cents; quart 50 cents. By express, quart 40 cents; peck $\$ 2.00$.

\section{Extra Early Red Valentine.}

A decided improvement on Red Valentine, being fully a week earlier. Healthy, robust habit; pods four inches long, round, fleshy, brittle, free from strings and of excellent quality. A universal favorite for the home and market garden, ripening the entire crop uniformly early. Price, pkt. 5 cts.; $1 / 2$ pint 15 cts.; pint 25 cts.; quart $40 \mathrm{cts.}$ postpaid. By express, not prepaid, quart $30 \mathrm{cts}$; peck $\$ 1.50$.

\section{Other Varieties of Great Merit.}

Early Round-Pod Six Weeks. Extra early, vigorous and healthy. Pods large, round, fleshy, stringless. Flavor most excellent. A favorite among market gardeners. Pkt. 5 cts.; $1 / 2$ pint $15 \mathrm{cts}$; pint $25 \mathrm{cts}$; quart $40 \mathrm{cts}$. By express, quart $30 \mathrm{cts}$.; peck $\$ 1.50$.

Longfellow. Extra early; very highest quality. Pods round, straight, fleshy, brittle, entirely stringless. Delicate green color is retained when cooked. Very desirable. Packet 5 cents; $1 / 2$ pint 15 cents; pint 25 cents; quart 40 cents. By express, quart 30 cents; peck $\$ 1.50$.

SEEDS IN LARGER 2 UANTITIES.

Market gardeners and others who need seed in larger quantities will do well to write us for special prices. State quantity wanted.

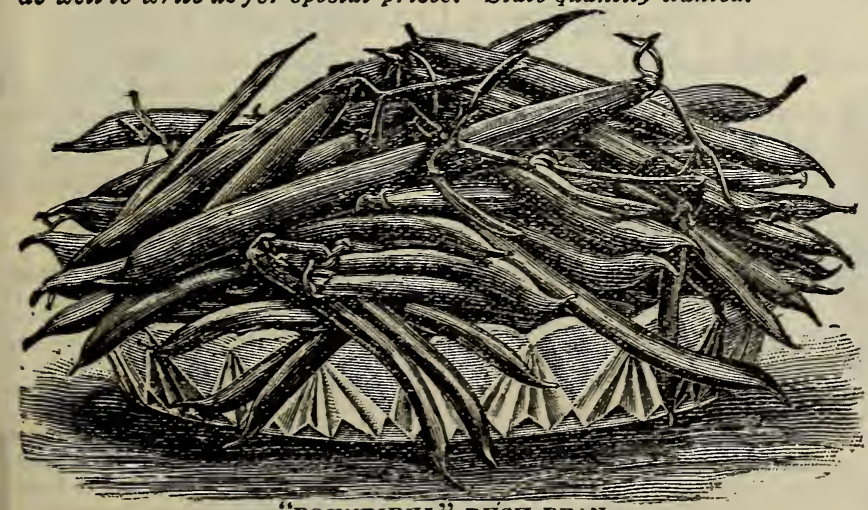

"BOUNTIFUL" BÚSH BEAN,
BUSH BEANS.

(GREEN PODDED.)

CULTURE.-Beans of all kinds are rather tender, should not go into the open ground until all danger

Each packet will contain two ounces, sufficient to 20 to 30 hills. 1 quart to 175 feet of drill; $11-2$

A most excellent variety. It was among the best Low's Champion. Matures with Valentine and Burpee's String cents; pint 30 cents; quart 50 cents. By express, quart 40 cents; peck $\$ 2.00$.

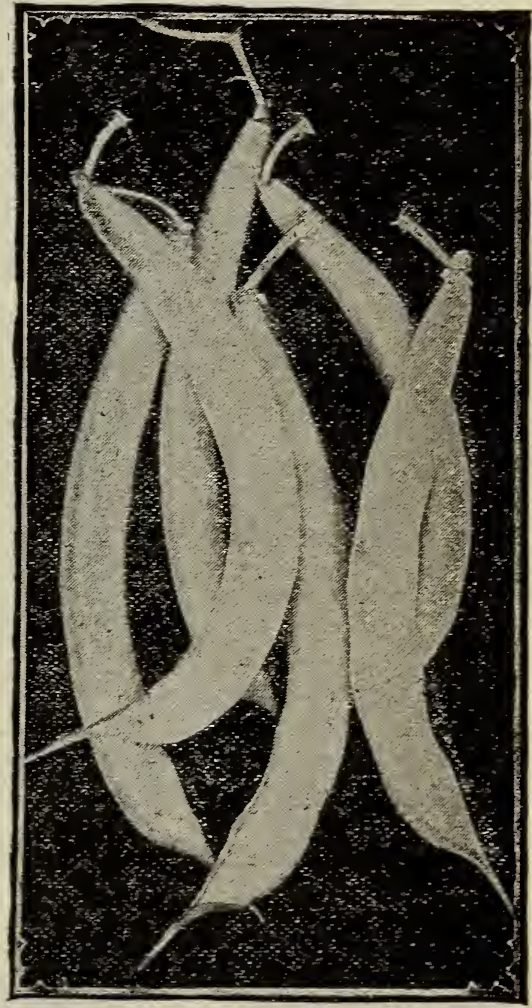

\section{Two Best Soup Beans.}

Boston Pea. These are smaller than Marrowfat, but ripen earlier. In high favor among the Field Bean growers of New York and Michigan. Quite productive; pods small and slender, each containing 6 to 8 small, pearly white beans. Sometimes called Dwarf White Navy Bean. Plrt. 5 cts.; $1 / 2$ pt. 12 cts.; pt. 20 cts.; qt. 35 cts. By express, qt. 25 cts.; pk. \$1.25.

White Marrowfat. The standard white Soup Bean. Larger than Dwarf White Navy, and slightly oval. Vines large. slender, spread. ing, with short runners and small leaves: pods broad, green changing to jellow. Very early and productive. Pkt. 5c.: 1/2 pt. 12c: pt. 20c:i qt. 35c. By express, qt. $25 \mathrm{c}_{\text {.; }}$ pk. $\$ 1.25$, 


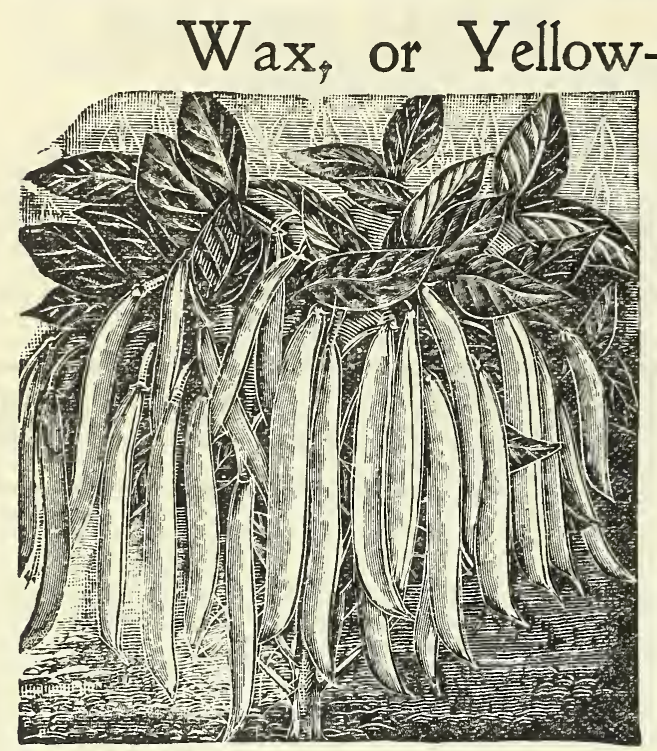

RUST-PROOF GOLDEN WAX.

Podded Bush Beans.

\section{Rust-Proof Golden Wax.}

This is a decided improvement on the old Golden Wax. It is a strong grower, possessing remarkable vigor and freedom from rust. The plants stand stifly erect, bearing the crop well above the ground. The pods are broad, rather flat when young but semi-round and well filled later; rich yellow, quite brittle, entirely stringless even when quite old enough to shell. Quality all that could be desired. If pods are picked as fast as large enough for snaps the plants will continue to furnish a bountiful supply for an unusually long season, being practically everbearing until frost. It possesses every quality required for the home and market garden. Price, postpaid, packet 5 cents; $1 / 2$ pint 15 cents; pint 25 cents; quart 40 cents. By express, not prepaid, quart 30 cents; peck $\$ 1.75$.

\section{Jones' Stringless Wax.}

The most desirable Wax Bean introduced for many years, and we cheerfully recommend it to our patrons as a variety that will give satisfaction. It is a sellow podded variety with white seed. The pods are round and attain a length of from five to seven inches, being thick and fleshy when in the green stage, and present a very handsome appearanee in the market. The pods are entirely stringless. The beans are of superior quality both in the green and dry stages, It holds its fresh ap pearance for a long time after picking, a quality that market gardeners will appreciate vers much. Pkt. 5 cents: $1 / 2$ pt. 15 cts; pt. 25 cts; qt. 40 cts. Express q t. 30 cts; pk $\$ 1.75$

\section{Yosemite Mammoth Wax.}

This is a very popular Wax Bean for family or market. It is enormously productive, as many as 50 of its monster pods on one bush. The pods frequently attain a length of from 10 to 12 inches, with a thickness of a man's finger, and are nearly all solid pulp, the seeds being small when the pods are fit for use. The pods are rich golden yellow and absolutely stringless, being very tender and luscious when cooked. Price, packet $5 \mathrm{cts}$; $1 / 2 \mathrm{pt}, 15 \mathrm{cts} ; \mathrm{pt} .25 \mathrm{cts}$; qt. $40 \mathrm{cts}$. By express, not prepaid, qt. $30 \mathrm{cts}$; pk. $\$ 1.75$.

\section{Prolific German Black Wax.}

An improved strain of Black Wax. It is of dwarf, bushy growth and wonderfully prolific. 'This is the earliest maturing wax-podded variety. Pods 4 to 5 inches in length, usually curved, quite round, meat $y$, brittle and entirely stringless; deep golden yellow. Of most excellent flavor. Price, postpaid, packet 5 cts; $1 / 2$ pint 15 cts; pint 25 cts; quart $40 \mathrm{cts}$. By express, quart $30 \mathrm{cts}$; peck $\$ 1.75$.

\section{Pencil-Pod Black Wax.}

This grand new variety is very highly praised by all who have grown it. The plants are of true bush form, about 15 inches high, with an abundance of large, heavy foliage, under which will be found, in great abundance, the magnificent, straight pods that are from 5 to 7 inches long, light golden yellow in color, beautifully rounded; very meaty and deeply saddle-backed. 'The pods are always solid, brittle and entirely stringless. Price, postpaid, pkt. 5 cents; $1 / 2$ pint 15 cents; pint 30 cents; quart 50 cents. By express, quart 40 cents; peck $\$ 2.00$.

Market Gardeners and others wanting Beans in larger quantities will please write us for special prices. We can save you money.

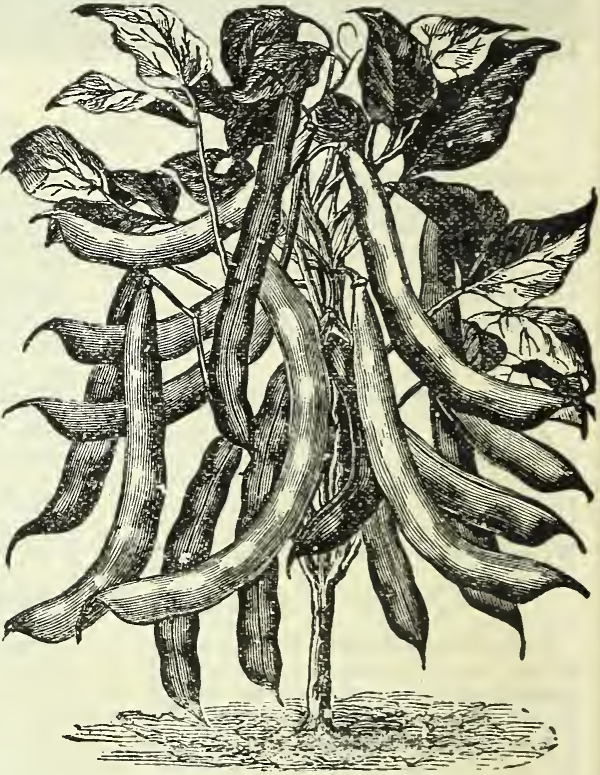

YOSEMITE MAMMOTH WAX.

\section{* Select Dwarf Bush Lima Beans. *}

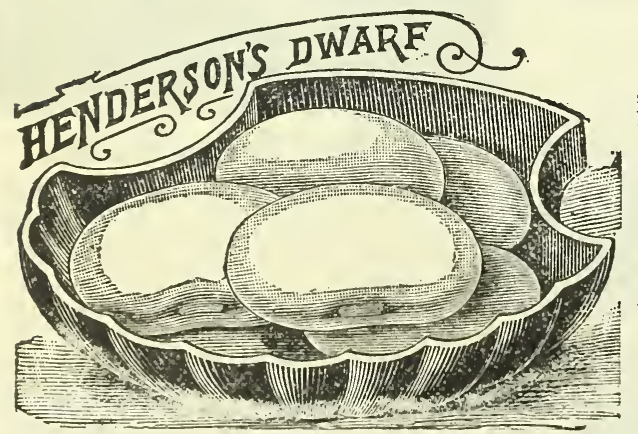

Henderson's Dwarf Bush Lima.

Wonderfully prolific, though not quite so large as Burpee's. It is at least two weels earlier than any of the climbing Limas, and produces continuous crop until frost. Being enormously productive, a very small patch will keep a family supplied throughout the season. Fine for market gardeners: Price, packet 5 cents: $1 / 2$ pint $15 \mathrm{cts}$; pint $25 \mathrm{cts}$; qt. $45 \mathrm{cts}$. Express qt. $35 \mathrm{cts} ; \mathrm{pk} \$ 1.75$

\section{Wood's Prolific Bush Lima.}

A very prolific, reliable cropper. A strong grower, the stalks bearing the crop well above the ground. One of the earliest to mature its crop, and has proven very satisfactory everywhere w ith home and market gardeners. We can heartily recommend this variety to our patrons. Price, post paid, packet 5 cents, $1 / 2$ pint 15 cents: pint 25 cents; quart 40 cents. By express, not prepaid, quart 30 cents; peck $\$ 1.75$.

ORDER EARLY. It will be greatly to your advantage to send in sour Seed order early. By so doing your order ken by the 


\section{Wax, or Yellow Pod Pole Beans. Golden Carmine Horticultural.}

An excellent variet $y$. The pods are large, 6 to 8 inches long, fleshy, brittle and remarkably free from strings. Bright yellow when young. brown, streaked with rich carmine when ready for market. A strikingly beautiful variety. Equally valuable for snap beans and shell beans for winter use. Its size, high quality and beauty makes it most desirable for home and market. Pkt. $5 \mathrm{cts}$; $1 / 2 \mathrm{pt} .20$ cts.; pt. 30 cts.; qt. 50 cts. By express, qt. 40 cts.: pk. $\$ 2.00$.

\section{Golden Champion Wax.}

One of the finest Pole Beans. Pods long, cylindrical, bright golden-yellow, fleshy, stringless and excerdingly productive. Desirable for using like Snap Beans; also may be used as a winter Shell Bean. Possesses much more than ordinary merit, both for the home and market garden. Also in great demand for planting among corn, as it climbs rapidly and twines loosely around the stalks. Price, post paid, packet 5 cents: $1 / 2$ pint 15 cents: pint 25 cents: quart 40 cents. By express, quart 30 cents; peck $\$ 1.75$.

\section{Early Golden Cluster Wax.}
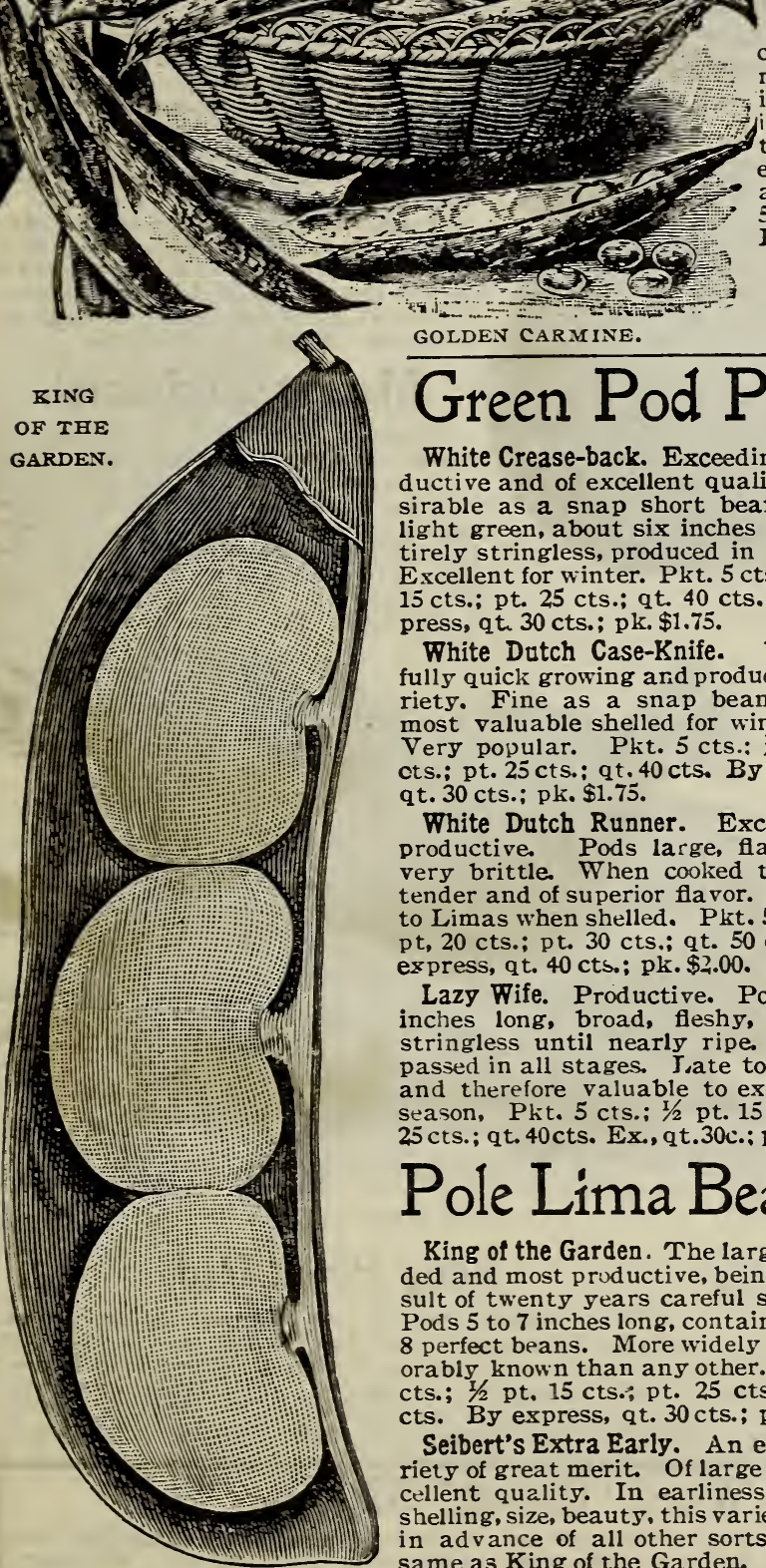

GOLDEN CARMINE.

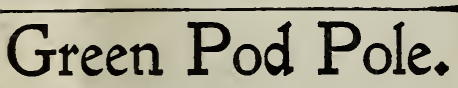

White Crease-back. Exceedingly pro ductive and of excellent quality. Desirable as a snap short bean. Pods light green, about six inches long, entirely stringless, produced in clusters. Excellent for winter. Pkt. 5 cts.; $1 / 2 \mathrm{pt}$. 15 cts.; pt. 25 cts.; qt. 40 cts. By express, qt. 30 cts.; pk. $\$ 1.75$.

White Dutch Case-Knife. Wonderfully quick growing ard productive variety. Fine as a snap bean, but is most valuable shelled for winter use Very popular. Pkt. 5 cts.: $1 / 2$ pt. 15 cts.; pt. 25 cts.; qt. 40 cts. By express, qt. 30 cts.; pk. $\$ 1.75$.

White Dutch Runner. Exceedingly productive. Pods large, flat, solid, very brittle. When cooked the $y$ are tender and of superior fla vor. Similar to Limas when shelled. Pkt. $5 \mathrm{cts}$. $1 / 2$ pt, 20 cts.; pt. 30 cts.; qt. 50 cts. By express, qt. 40 cts.; pk. $\$ 2.00$.

Lazy Wife. Productive. Pods 6 to 8 inches long, broad, fleshy, entirely stringless until nearly ripe. Unsurpassed in all stages. Jate to mature and therefore valuable to extend the season, Pkt. 5 cts.; $1 / 2$ pt. $15 \mathrm{cts}$; pt. $25 \mathrm{cts}$; q t. $40 \mathrm{cts}$. Ex., qt.30c.; pk. $\$ 1.75$.

\section{Pole Lima Beans.}

King of the Garden. The largest podded and most productive, being the result of twenty years careful selection. Pods 5 to 7 inches long, containing 5 to 8 perfect beans. More widely and favorably known than any other. Pkt. 5 cts.; $1 / 2$ pt. 15 cts.; pt. 25 cts.; q t. 40 cts. By express, qt. $30 \mathrm{cts}$; pk. $\$ 1.75$. Seibert's Extra Early. An early variety of great merit. Of large size, excellent quality. In earliness, ease of shelling, size, beaut 5 , this variety is fa in advance of all other sorts. Price same as King of the Garden.

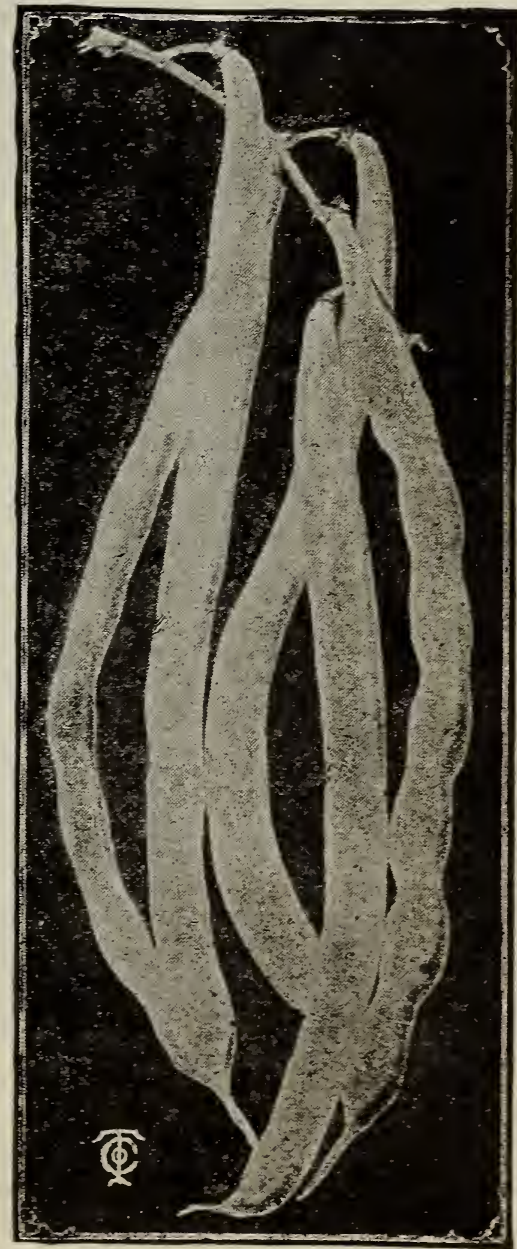

EARLY GOLDEN CLUSTER WAX.

See EXTRA EARLY JERSEY Pole Lima Bean on page 5. This is decidedly the earliest of the very large varieties. Market gardeners and wide-awake farmers have found it exceedingly profitable to grow for the early market. They bring a fancy price when shelled in the green stage. Order them in quantity and try for the early market. 


\section{Select Table Beets}
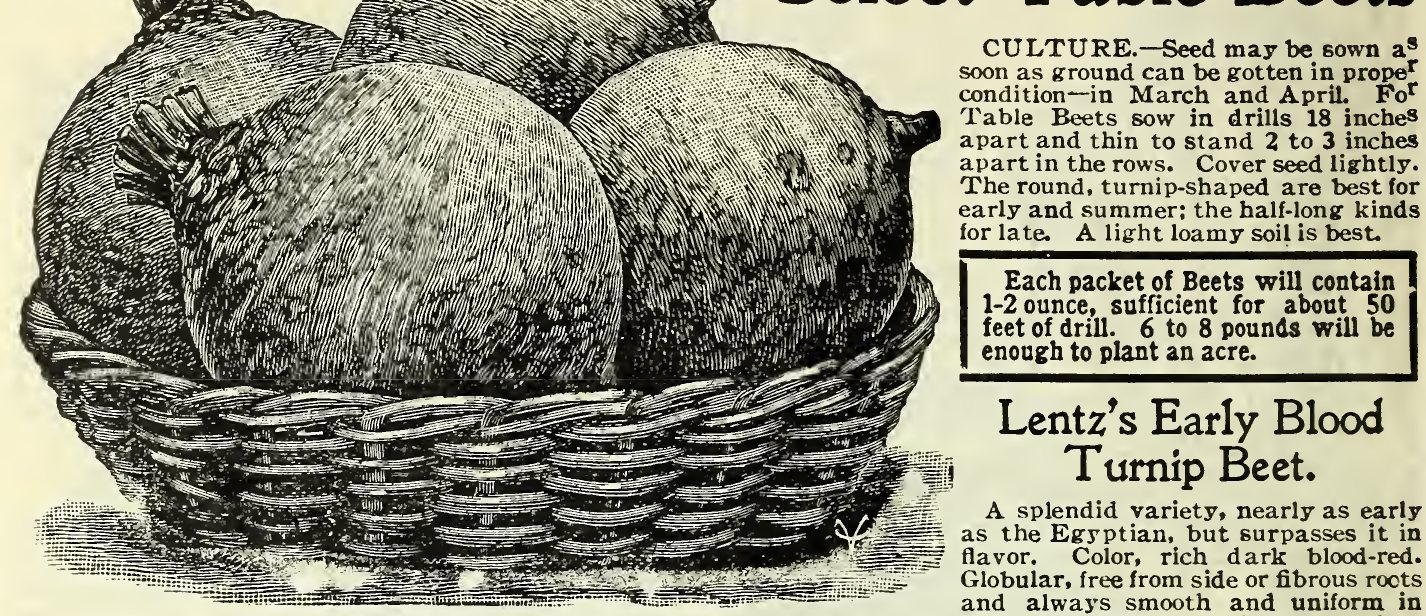

Each packet of Beets will contain 1-2 ounce, sufficient for about 50 feet of drill. 6 to 8 pounds will be enough to plant an acre.

\section{Lentz's Early Blood Turnip Beet.}

A splendid variety, nearly as early as the Egsptian, but surpasses it in flavor. Color, rich dark blood-red. Globular, free from side or fibrous rocts and always smooth and uniform in shape. A splendid variety for forcing,

Ideal Table Beet.

We are especially pleased with this new Table Beet as grown on our trial grounds along with other varieties. It is round, somewhat resembling the popular Crosby's Egyptian. Color, a brilliant blood red. Flesh crisp and tender and of excellent quality. Top small as compared with some other varieties. We do not hesitate to recsmmend the Ideal Table Beet for the table or market. Price, pkt, 5 cts.; $0 z$. $10 \mathrm{cts}$, $1 / 4 \mathrm{lb}$. $25 \mathrm{cts}$.: 1 b. $75 \mathrm{cts}$. By express, pound 65 cents.

\section{Early Eclipse.}

This is one of the earliest and handsomest Beets grown. It is remarkable not only for its wonderfully quick for its uniform, perfect shape, and the smallness of its top. It is alwass perfectly smooth and round in shape; skin and flesh blood red; flesh fine grained, crisp and sweet. It matures early and is popular both for home and market garden. Price, pkt, $5 \mathrm{cts}$; $0 z, 10 \mathrm{cts}$. 1/4 1b. $20 \mathrm{cts}$. 1b. $60 \mathrm{cts}$. Ву express, pound 50 cents.

\section{Crosby's Egyptian.}

A very superior strain of Blood-Red Egyptian carefully selected for years by Mr. Crosby, a noted market gardener, whose aim was to secure a perfect forcing variety. Handsome form, good size, small top, very small tap root, fine quality: and above all, quick, rapid growth. Takes on its Turnip shape very earls, a decided advantage for forcing for real early market, and especially for a market where beets are sold in bunches. May be sown outside as late as July. Price, pkt. 5 cts.: $0 z .10$ cts.; $1 / 4$ 1b. 25 cts.; 1b. cts. By express, pound 65 cents.

Edmand's Early Turnip. This splendid Beet is thoroughly fixed and uniform in type, being handsome, round, always smooth and of good marketable size. Skin and flesh dark blood red, ver tender and sweet. Fine for market gardeners who grow Beets for bunching. Price, pkt. 5 cts.; oz. $10 \mathrm{cts}$; $1 / 4 \mathrm{lb}$. $20 \mathrm{cts}$.; $1 \mathrm{~b}, 60 \mathrm{cts}$. By express, 1b. $50 \mathrm{cts}$.

Crimson Globe. Medium size, slightly oblong, smoth. Very regular in size and form. Flesh purplish, slightly zoned. Superb quality. Fine for market. Pkt. $5 \mathrm{cts}$.; oz. $10 \mathrm{cts.}$ : $1 / 4$ lb. $20 \mathrm{cts}$ : $1 \mathrm{~b}, 60$ ets. By express, $1 \mathrm{~b} .50 \mathrm{cts}$.

\begin{abstract}
ECLIPSE BEET. iods of growth. Beautiful dark red color throughout. Price same as Lentz's.
\end{abstract} use. The quality is first rate at all perfor a main spring and summer crop, or for use in winter. It has made a good crop in about six weeks from sowing. A profitable varicty for the market gardener. It is fine grained, cooks sweet. tender and crisp; every way a standard sort for the market and home gardener. Price, pkt. 5 cts.: oz. 10 cts.: $1 / 4$ lb. 20 cts; lb. $60 \mathrm{cts}$. By express, $1 \mathrm{~b} .50 \mathrm{cts}$.

\section{Market Gardeners'.}

This new Beet is one of the best for $n$ arket gardeners and farmers. It is of very rapid growth from the start, and is larger than Egrptian. Only one sowing is necessary to produce early Beets for market and a main crop for winter

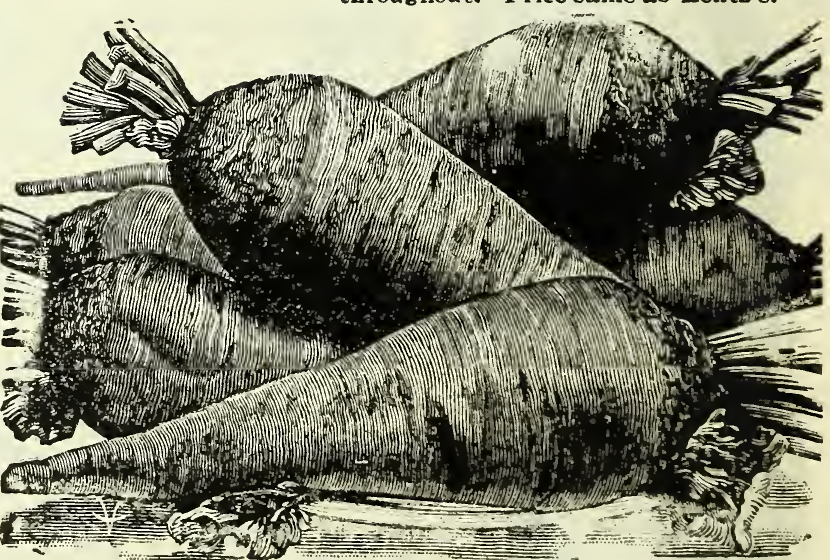

LONG BLOOD RED.

One of the best for winter use. Thes a re always smooth and handsome, and their rich dark flesh is very sweet, tender and of high table excellence, retaining their sweet flavor throughout the season. The above illustration shows the shape of this superb variet $y$. Price, pkt. 5 ct.s.: 0z, $10 \mathrm{cts}$.: $1 / 4$ Ib. $15 \mathrm{cts}$.; $1 \mathrm{~b} .50 \mathrm{cts}$. By express, $1 \mathrm{~b} .40 \mathrm{cts}$,

\section{What Does The Word "Packet" Mean?}

What does the word "packet" mean ordinarily in seedsmen's catalogues? In most other catalogues the word "packet" stands for an unknozwn quantity. A packet may be large, small, full or nearly empty". You don't know just what to expect. Is this fair to the buyer, when the standards of weights used by all otber merchants are fixed by law, with a penalty for light weight and short measure?

WE STATE IN OUR CATALOGUE JUST WHAT QUANTITY OF SEED IACI PACKET CONTAINS. 


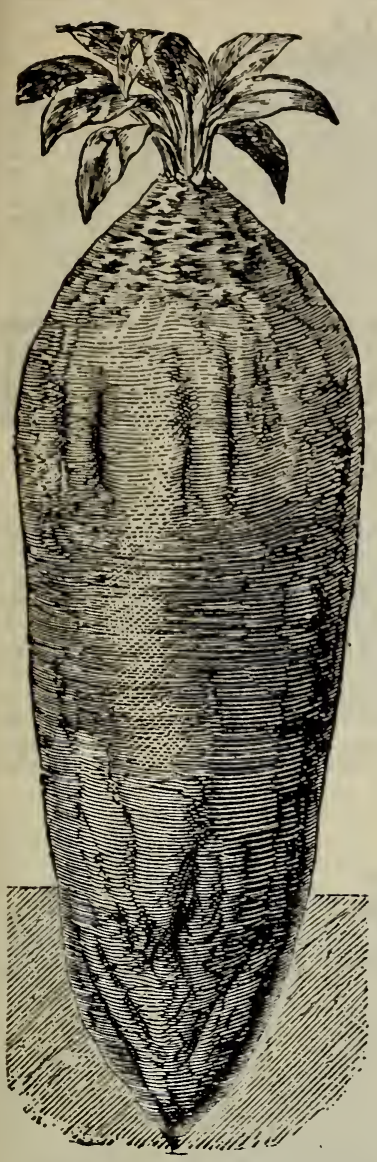

GOIDEN GIANT.

\section{Select Mangel Wurzels.}

CULTURE. - There is no crop grown by farmers that is so valuable for feeding stock and poultry during winter as Mangels and Sugar Beets. Five to eight tons can be easily grown on one acre. The entire crop is perfectly digestible, there being no waste. With dairy cows the flow of milk is largely increased and the quality much improved. When planting sow in rows $2 \frac{1}{2}$ to 3 feet apart, and thin to stand 6 to 8 inches apart in the rows. 6 to 8 pounds will plant an acre.

\section{Golden Tankard.}

The best yellow Mangel in cultivation. A distinct and valuable yellow-fleshed variety which contains a large percentage of sugar and nutritive matter. It has taken the lead of other varieties in England, and is more relished by milch cows and sheep than any other. In shape it is almost cylindrical. It is very easily pulled, and yields an enormous bulk on good land. Pkt. 5c.; oz. 8c. 1/4 1b. 13c.; 1b. 35c. Express lb. 25c.

\section{Golden Giant.}

Yellow Leviathan. One of the most desirable and largest yellow Mangels, having been grown to weigh 30 pounds. Russety yellow; even shape and smooth skin; grows well above ground. Produces enormous crops and is an excellent keeper. Pkt. 5c.; oz. 8c.; $1 / 4$ 1b. 15c.; 1b. 35c. By express, not prepaid, pound 25 cents.

\section{Mammoth Large Red.}

The best large red variety. ${ }^{\circ}$ Frequently grow two feet or more in length, weighing 15 to 20 pounds. Produce 1200 to 1500 bushels per acre. Price, prepaid, per pkt. 5c; oz. $8 \mathrm{c}$; $1 / 4$ lb. $15 \mathrm{c}$.; 1b. $35 \mathrm{c}$. By express, not prepaid, pound 25 cents.

\section{Sugar Beets.}

Culture same as for Mangel Wurzels. While the yield is not so great ordir.arily as for Mangel Wurzels, many farmers prefer the Sugar Beet for feeding purposes, since the saccharine or sugar contained in them renders them much more nutritious than the Mangels.

\section{Danish Dairy.}

Cattle Sugar Beet. A valuabie new and distinct strain which we procure direct from the producer in Denmark. They grow to very large size and heavy weight. Areextremely rich in sugar, hence of superior value for dairy cattle, promoting an increased flow of rich milk. Has produced more than five tons of roots to the acre. Flesh white; skin white, flushed pink. Packet $5 \mathrm{c}$.; oz. 8c.; $1 / 4$ pound $15 \mathrm{c}$. pound 45 cents. By express, not prepaid, pound 35 cents.

\section{Lane's Imperial Sugar.}

The Imperial sugar is considered the best of its class to grow for stock, being more uniformly large and smooth than most varieties of Sugar Beets. Packet Ec.; 0z. 8c.; 1/4 1b. 15c.; 1b. 45c. Ex.1b. 35c.

\section{Select Swiss Chard.}

A r a riety of Beet grow $/$ for its leaves. The fleshy leaf-stalks and mid-ribs are highly esteemed when rooked and served like As paragus. Flavor similar to Spinach. Fine as "greens ;" also for pickling, the three colors mixed being very attractive.

CULTURE. - Sow early in the spring, in rows 16 inches apart; thin to six inches in the row.

Golden Ribbed. Words cannot describe the richness and beauty of this variety. The large, broad, flat, wax-like stem, mid-ribs and delicate veins a re bright golden-yellow.

Scarlet Ribbed. In vivid, gorgeous color this variety excels. Color, dazzling and beautiful scarlet; even the foliage is heavily tinged scarlet and bronze.

Silver Ribbed. Sometimes called "Silver Beet," though it seldom produces a bulbous root. The leaf-stalk, mid-rib and delicate veins are all of clear, silvery, wax-like, ivory whiteness.

Price, each, pkt. 5c.; oz. 10c.; 1/4 1b. 20c.; 1b. 60c. Express, 1b. 50c.

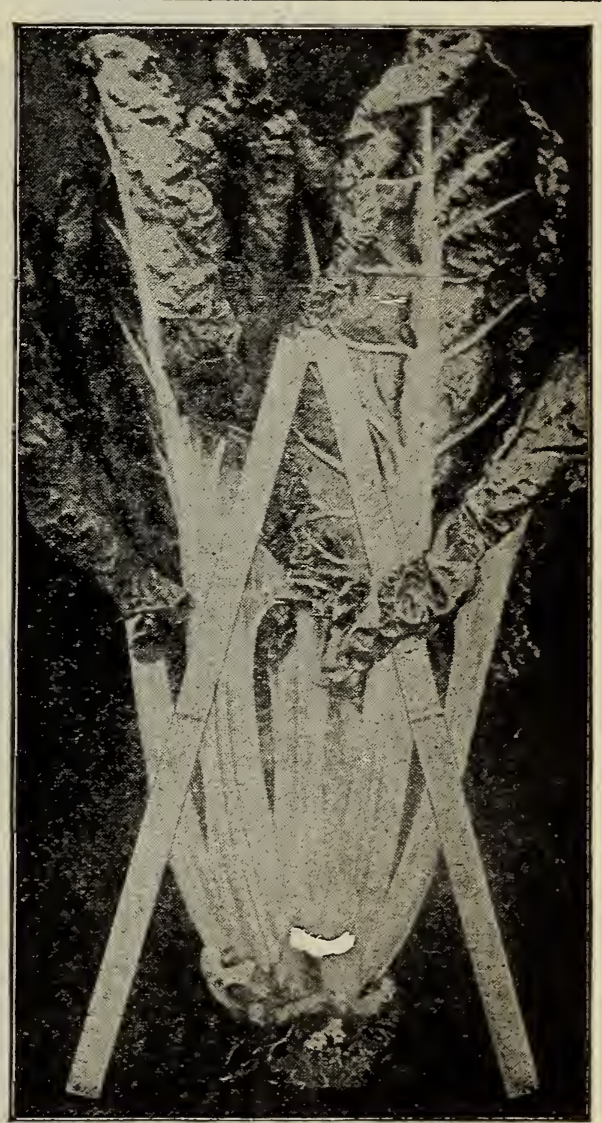

SWISS CHARD.

The great importance of procuring good Seeds is a matter that is generally not fully appreciated. The difference between success and failure in the products and profits obtained from the garden is usually determined by the Quality of the Seeds you buy. If the strain is not good a perfect crop cannot be grown, even on the best soll.

"1 11 ITY ") When we speak of "quality" zve do not mean simply the pozver to germinate and grow. It 10111 , has a much vider meaning, for manv seads vill grow. Quality is shozun only oy the high grade, perfection, and quantity of the crop produced. The real "quality" in any particular variety or strain of seed is obtained only by painstaking care, on the part of the grower: zwho must, for a series of years, carefully "rogue" or cull out all plants that are not true to his ideal, in their characteristics. This takes constant vigilance on his part, but it insures the plants producing a profitable crop. Unfortunately there are growers who are not thoroughly reliable along this line. 


\section{Selected Varieties of Early Cabbage.}

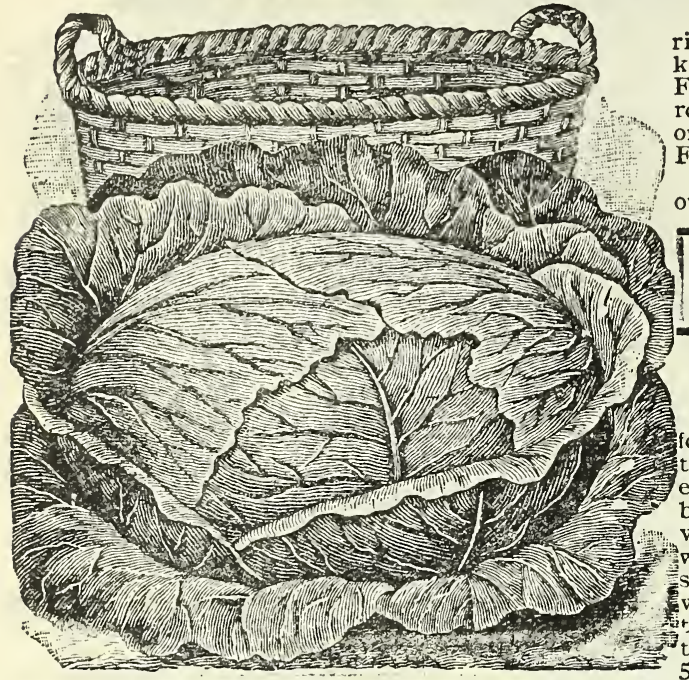

HENDERSON'S EARLY SUMMER.

\section{Henderson's Early Summer.}

This is deservedly popular among market gardeners as an early summer variet $y_{0}$ It matures about ten days later than Wakefield. It forms large, solid, round, flattened, compact heads, and nearly double the weight of Wakefield. The leaves fold close to the head and it may, therefore, be planted very closely; as many as 11,000 to 12,000 to the acre. It is indeed one of the best of the large early va rieties, being especially valuable for the market gardener. We offer a very fine strain of seed. Price, postpaid, packet 5 cents; ounce 15 cents; $1 / 4$ pound 50 pound \$1.75. By express, not prepaid, pound $\$ 1.65$.

\section{Earliest White Giant.}

This new German sort is said to be the earliest of the large, round head Cabbages, producing its enormous heads during July. The heads of this variety are fine ribbed, and of exceedingly fine flavor. This sort comes to us highly recommended, and by the highest a uthority. Price, packet $5 \mathrm{cts} ; 1 / 2$ ounce $15 \mathrm{cts}$; ounce $25 \mathrm{cts} ; 1 / 4 \mathrm{lb}$. $65 \mathrm{cts}$; pound $\$ 2.00$. By express, pound $\$ 1.90$.

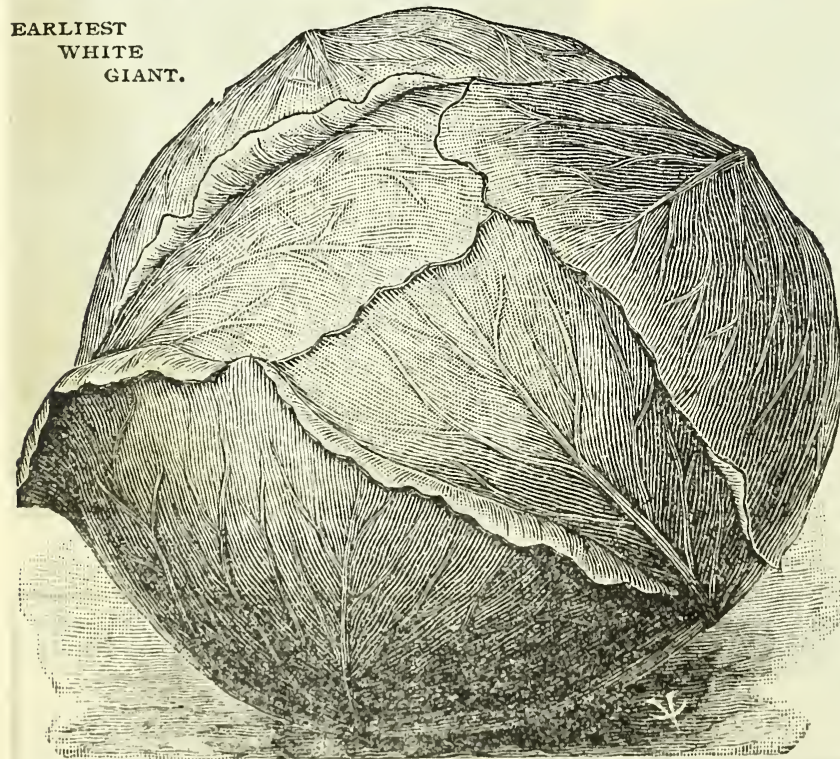

CULTURE-Cabbage is a gross feeder and requires deep, rich mellow soil, that is well drained. Sow seeds of the early inds in a hot-bed, or in a box in the house during the last of February; transplant in the open ground during April, in rows 30 inches a part and 18 inches a part in the row. For second early sow seeds in A pril and transplant during June. For la te sow seeds in May and transplant during July.

Complete instructions for $\mathrm{g}$ rowing Cabbage will be found in our 140-page book, "The Family Garden." Price, 25 cents.

Each packet of Cabbage seed will contain one-eighth of an ounce; sufficient to grow about 250 plants. One ounce will produce about 2,000 plants. 8,000 will plant an acre.

\section{Early Winningstadt.}

One of the most famous old varieties. In 'season it closely ollows Wakefield, but the heads a re slightly larger, of the rue cone-shaped type. It is a sure header, even where other early varieties fail. It is sometimes planted in the autumn, because of its excellence and quick maturing. The heads a re very solid and keep remarkably well, both in summer and inter. Market and private gardeners rely upon Winningad for an early and sure crop. With this as with all other arieties, the sure heading of the crop depends largely upon he selection and purity of the stock. The seed we offer of this variety is of the very best strain. Price, postpaid, packet press, not prepaid, pound $\$ 1.65$.

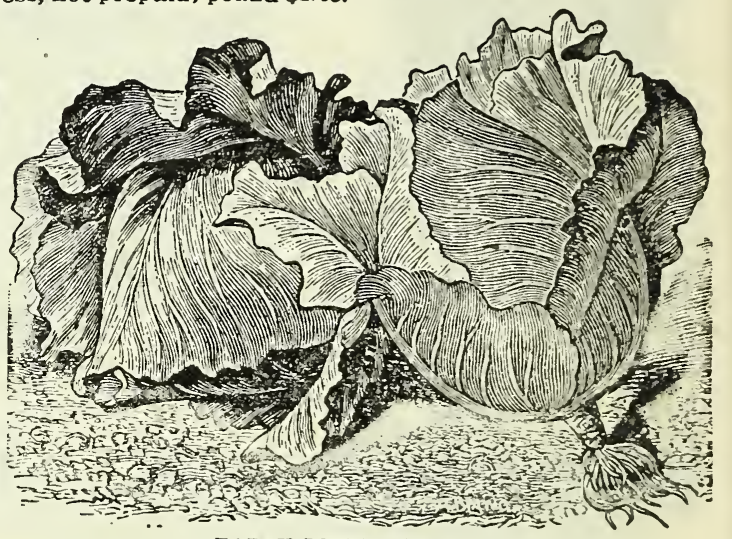

EARLY WINNINGSTADT.

\section{Early Express.}

Claimed by some to be the earliest Cabbage. It was introduced about 15 years ago and still retains its place at the head of the extra early varieties. It has been known to head in from 70 to 80 days, and is therefore a valuable addition to the list of early sorts. It can be planted close together, as there a re few loose leaves, and being a sure header it produces a la-ge crop. It forms compact, conical heads of medium size. and though not quite as large as Wakefield, it matures several day's earlier, which makes desir able for market. Packet $5 \mathrm{cts}$; $1 / 2$ ounce $15 \mathrm{cts}$; ounce $25 \mathrm{cts} ; 1 / 4$ pound $50 \mathrm{cts}$; pound $\$ 1.75$. By express, not prepaid, pound $\$ 1.65 \mathrm{cts}$.

\section{Two Best Early Cabbage.}

GLORY OF ENKHUIZEN. On page 6 you will find illustration, descrption and prices of this superb Early Cabbage. The originator claims that it produces nearly double the crop of any other very early variety.

EARLY JERSEY WAKEFIELD. This grand old standard variety will also be found on page 6 . It is so well known as to need no description. The seed we offer were produced from extra selected stock, under the care of the oldest and most experienced growers in the country. Order Cabbage Early. If you want early Cabbage it will be greatly to your advantage to send in hot-bed. You can thus have plants of good size and well hardened when the ground is in condition for planting. 


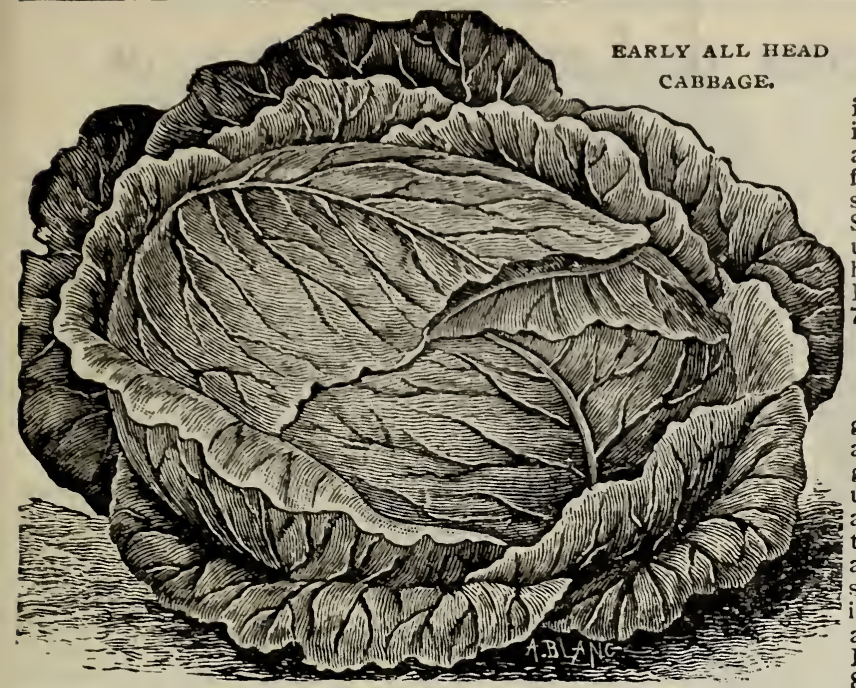

Early All-Head.

A comparatively new flat-head Cabbage. It is the earliest of all large headed varieties. It s adapted to a wide range of soil and climate. and is a standard solt. It is a money maker size, being fully one third larger than the Early Summer. The deep, flat heads are remarkably niform in size, shape and color. Its compact habit of growt h renders close planting possible.
Price, pkt. $5 \mathrm{cts} ; 1 / 2 \mathrm{oz} .15 \mathrm{cts}$; 0z. $25 \mathrm{cts} ; 1 / 4 \mathrm{lb}$. 75 cts; 1 b. $\$ 2.00$. By express, pound $\$ 1.90$.

\section{Early Spring.}

An early flat-head Cabbage having all of the good qualities of Early Summer. Matures just after Wakefield and yields very large crops. Its growth is rapid, size and shape uniform, heading up as quickly as the pointed varieties; the heads veraging one-fifth hea vier. Lea ves so small as permit closer planting than most varieties; as many as 12.000 can be grnwn to the acre. The tems are short and extend but a little way nto the head. Of most excellent quality, and dapted to both the home and market garden. Price, packet 5 cts: $1 / 2 \mathrm{oz} .15 \mathrm{cts}$; 0 z. $25 \mathrm{cts}$; $1 / 4 \mathrm{lb}$. $80 \mathrm{cts} ; 1 \mathrm{~b} . \$ 2.30$. By express, pound $\$ 2.20$.

\section{Henderson's Succession.}

This is considered one of the most excellent varieties. It is properly classed with the second early, maturing a few days later than Early Summer. Can be grown to perfection in the hottest weather, or can be used as an autumn or winter sort. The heads average 10 to 12 inches in diameter, but are of ten much larger. It is one of the safest varieties for the amateur to plant, as it does well at all seasons and is sure to produce a crop, no matter when planted. Remarkably true to type. Price, pkt. 5 cts; $1 / 2$ oz. 15 cts; 02.25 cts: $1 / 4$ lb. 75 cts; ib. $\$ 2.00$. By express, pound $\$ 1.90$.

\section{Vandergaw.}

Originated by Mr. Vandergaw, a lead ing Cabbage grower on Long Island, and is sent out by some dealers under the name "All Seasons," which is quite appropriate. as it is admirably adapted for second ear$1 \mathrm{y}$ as well as fall and winter use. The foliage is compact, glossy green, sometimes tinted with red. Heads are very large, thick, solid and heavy. Owing to its rather small foliage it can be planted quite closely, thus making it possible to produce hea vier crops than some others. We consider this one of the best for general planting. Price, postpaid, packet $5 \mathrm{cts}$; $1 / 2 \mathrm{oz}$. $15 \mathrm{cts}$; ounce 25 cents; $1 / 4$ pound $70 \mathrm{cts} ; 1 \mathrm{~b}$. \$1.75. By express, pound $\$ 1.65$.

See page 6 for Other Select Early Cabbage.

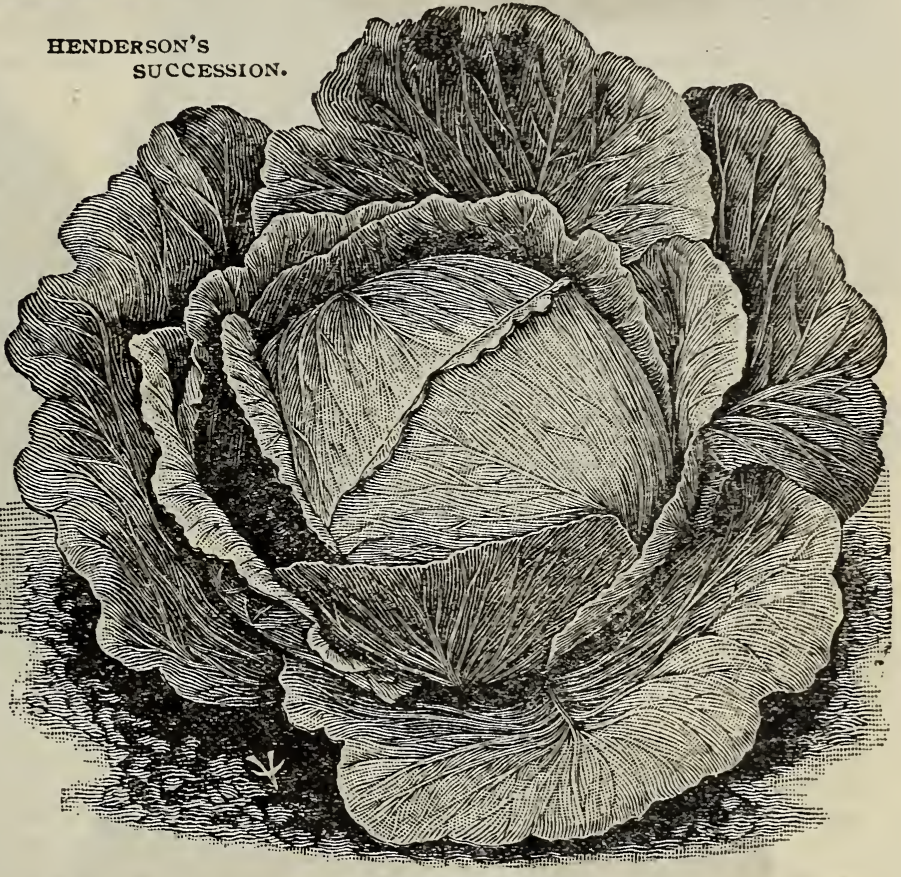

\section{Read What Our Patrons Say About Our Cabbage Seed.}

Gentlemen: "The Early Flat Dutch Cabbage purchased from you was very pleasing; it was really better than you recommended it to be. I grew them to weigh 18 pounds af ter all loose leaves were removed. And the Fersey Wakefield, there is no better Early Cabobage; it is so fine flavor$\mathrm{ed}$. The Ponderosa Tomato, there is no garden complete without it." A. E. McCONNELL, Culleoka, Tenn.

Gentlemen: "Enclosed find another order for Seeds. rou see I can't do without your Seeds, for they are the best I can get. I have thoroughly tested your Early Express Cabbage and it is the best I have ever grown; I except none. As long as I can get it I will plant no other. I have had them ready for use by May atth." rours truly,

Sarah T. Harper, Yount, Mo.
Gentlemen: "The past three seasons I have purchased Seeds from you. They have given excellent results and have the best garden in town. So much better than others that my friends and neighbors all a sk where I get my Seed. Among other Seeds I got this season was a packet of Hen. derson's Succession Cabbage. I sozved a few of them only, in a hot-bed, and when the plants were large enough I set a patch 18 by 25 feet. We began using Cabbage from that patch about Fune Ist., and have had all we wanted for table use besides selling $\$ 0.82$ worth and making about 8 gallons of kraut. We still have some left and I think the pig feed from the patch was worth a dollar or more. Can you beat that in Ohio?" G. E. Metzger, Feweler.

Morrison, Okla.

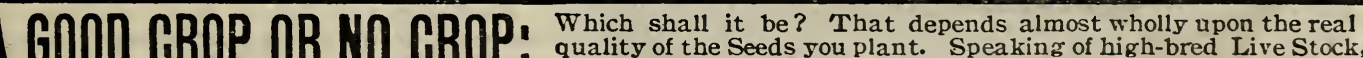

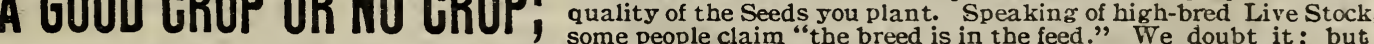
whether it be true or not, we are positive it is NOT the case with the crop produced from your garden, as no amount of extra care in planting, fertilizing and culture can possibly produce a good crop of Cabbage fron poor Seeds. Good Cabbage Seed are not the product of one seasons' growth. It takes many years of careful selecting and culling out of the inferior (poor headed) stalks to so improve a variety as to make it a sure heading strain. And this selecting and culling must be done by growers having years of experience and who are thoroughly trustworthy.

The above Unsolicited Testimonials clearly prove the Quality of our Cabbage Seed. 


\section{* Selected Varieties of Late Cabbage. \\ Premium Flat Dutch.}

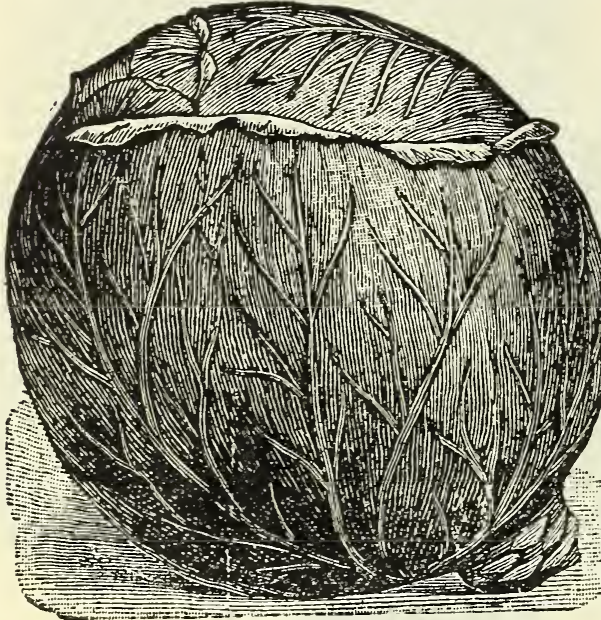

No Cabbage is so universally grown as this, and for the reason that the seed may be sown in the open ground and the young plants started without the use of a hot-bed, it is the favorite of all people for general use. Our strain of seed is reliable for heading. In evenness of crop and size it is unsurpassed. Do not be deceived by fancy names, but buy the genuine article under the old name, "Premium Flat Dutch," and you will get a first-class article. It is sufficient to say that there is no better strain on the market than we offer, and you can make no mistake by planting our seed. Price, packet $5 \mathrm{cts} ; 1 / 2$ ounce $15 \mathrm{cts}$; ounce $25 \mathrm{cts} ; 1 / 4$ pound $75 \mathrm{cts}$. pound $\$ 1.75$. By express, pound $\$ 1.65$.

\section{Burpee's Sure-Head.}

This is the celebrated Sure-Head Cabbage. It has gained teadily in popularity since its intruduction. Hardly any variety can approach Sure-Head in fine quality, and its uniform reliability in forming grand, solid heads of good size, fine color and hand. some appearance. It forms few loose outer leaves, and may therefore be planted very closely. Reports of 99 marketable heads from 100 plants set are not uncommon. The heads are very uniform in shape and size: very hard, and ine in texture. They ordinarily weigh from 8 to 12 pounds each. Price, packet $5 \mathrm{cts} ; 1 / 2$ ounce 15 cents; ounce 25 cents: $1 / 4$ pound 85 cis; pound $\$ 2.25$. By express, not prepaid, pound $\$ 2.15$.

\section{Late Stonehead.}

A superb sure-heading variety of quite distinct type. Of very strong, sturdy habit. Stems are quite short, leaving the large solid heads close to the ground. The heads are broad, "Solzd as a stone." The leaves forming the heads are tight-folded, becoming beautifully blanched. Owing to their great solidity they keep remarkably well when stored for winter use. Price, packet 5 cents; $1 / 2$ ounce 15 cents; ounce $25 \mathrm{cts} ; 1 / 4$ pound $85 \mathrm{cts}$; pound $\$ 2.25$. By express, pound $\$ 2.15$,

\section{Felderkraut.}

A German variety of great merit. A sure-header. The heads are very large, solid, conical. Hardy and thrives everywhere. Especially desirable for making kraut, owing to solidity of the heads. Price, packet 5 cents; $1 / 2$ ounce 15 cents; ounce 20 cents $1 / 4$ pound $60 \mathrm{cts}$; pound $\$ 1.75$. By express, pound $\$ 1.65$.

\section{The Houser Cabbage.}

This excellent late Cabbage is widely known. The heads weigh 8 to 10 pounds each; unsurpassed in solidity. Very compact in habit, and can be planted closer than most varieties. The shape is round and deep. A strong vigorous grower with ability to withstand drought better than most varieties. Our stock is of the very finest strain. Pkt. $5 \mathrm{c}$; $1 / 2 \mathrm{oz} 15 \mathrm{c}$; $0 \mathrm{z} 25 \mathrm{c} ; 1 / 4 \mathrm{lb} .80 \mathrm{c}$.
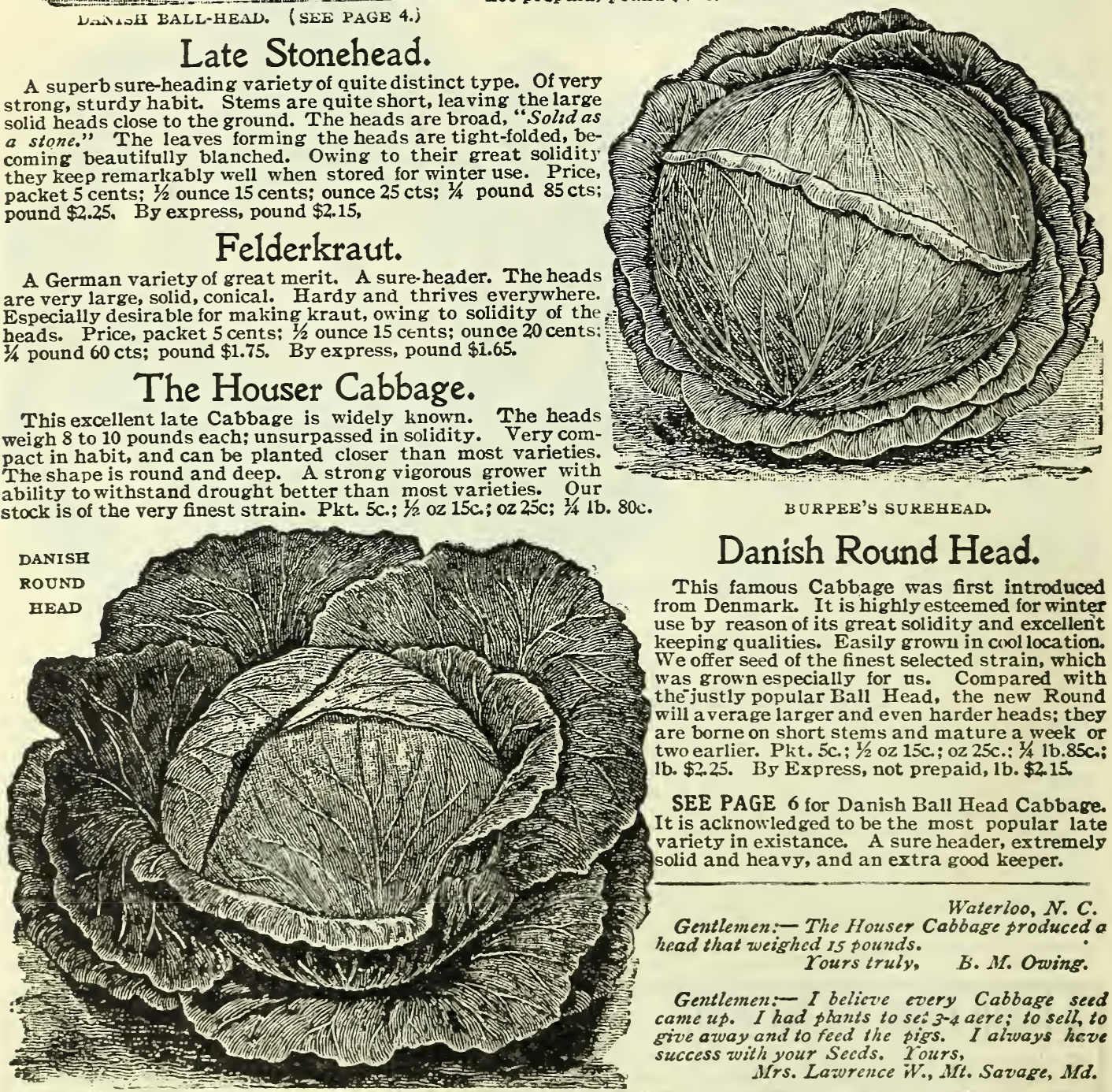

\section{Danish Round Head.}

This famous Cabbage was first introduced from Denmark. It is highly estcemed for winter use by reason of its great solidity and excellent keeping qualities. Easily growu in crol location. We offer seed of the finest selected strain, which was grown especially for us. Compared with the-justly popular Ball Head, the new Round will a verage larger and even harder heads; they are borne on short stems and mature a week or two earlier. Pkt. $5 \mathrm{c}$.; $1 / 2$ oz 15c; oz 25c.: 1/4 1b.85c.; 1b. \$2.25. By Express, not prepaid, 1b. \$2.15.

SEE PAGE 6 for Danish Ball Head Cabbage. It is acknowledged to be the most popular late variety in existance. A sure header, extremely solid and heavy, and an extra good keeper.

Gentlemen:- The Houser Cob

Waterloo, N. C. Cabbage produced a head that weighed 15 pounds.
Yours truly.

B. M. Owing.

Gentlenen:- I belicve every Cabbage seed came up. I had plants to set 3-4 aere; to sell, to give away and to feed the pigs. I always heve success with your Secds. Pours,

Mirs. Lazurence W., Mt. Savage, Ma.

Our Discount is given in the price quoted. The unfair feature connected with the "Discount" method bidding for trade is tho fact that the unsuspecting customer is led to believe that the is of the first price asked. We guarantee that you will be pleased in every particular with our seeds. 


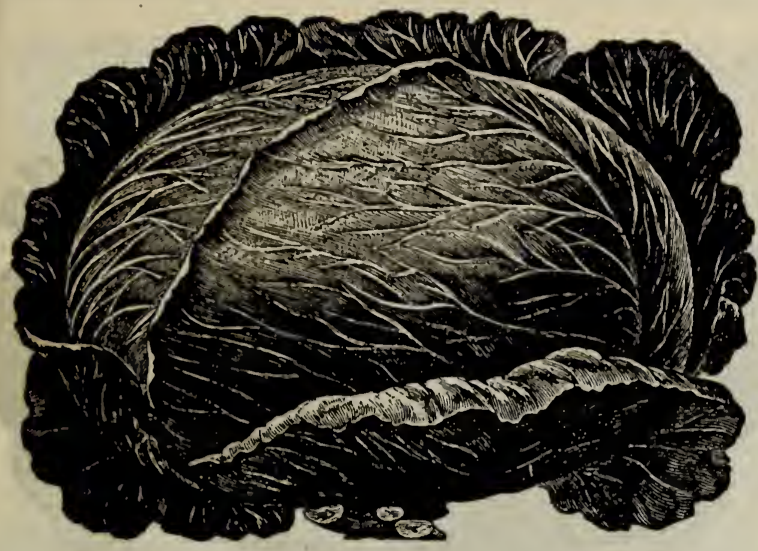

\section{The Lupton.}

This is a splendid variety of Late Cabbage of recent introduction. In habit of growth it is between the Sure-Head and popular old Flat Dutch, although more vigorous than either. A little earlier than Flat Dutch. Heads large in proportion to the plant, which is a strong grower, but does not spread out much, hence will stand comparatively close planting. It is an exceptionally fine keeper, coming out in the spring bright and fresh. More uniform in size and shape than most other late varieties. Heads always solid. and in quality are all that could be desired for either home or market purposes. We think this one of the most desirable late varieties grown. The seed we offer is of the very best strain. Pkt. $5 \mathrm{cts} ; 1 / 2 \mathrm{oz} .15 \mathrm{cts}$; oz. 25 cts: $1 / 4$ lb. 75 cts; 1b. $\$ 2.25$. Express, 1b. $\$ 2.15$.

THE CELEBRATED LUPTON.

\section{Large Late Drumhead.}

One of the safest varieties for the amateur to plant, as it does well in all sections. Though an old variety it is very popular because of its very large size and excellent quality. Heads are ext ra hard and very uniform in size. The seed we offer is of a most excellent strain. Packet $5 \mathrm{c}: 1 / 207.15 \mathrm{c}$ : Q2. 25c; $1 / 4$ 1b. 75c; 1b. $\$ 2.25$. Express, 1b. $\$ 2.15$.

\section{Other Choice Varieties.}

Price, each, pkt. 5 cts; $1 / 2$ oz. 15 cts; oz. 25 cts; 1/4 lb. 60 cts: $1 \mathrm{~b} . \$ 1.75$. By express, $1 \mathrm{~b} . \$ 1.65$.

Fottler's Improved Brunswick. A splendid variety of very rapid but dwarf and compact habit. Heads very large, uniform and solid.

Luxemburg. Heads medium, very solid and heavy. For late spring it has no superior, and always brings top-notch prices.

Mammoth Rock Red. The largest and finest heading of the deep red varieties. It is unsurpassed for pickling.

American Savoy. The hardest headed Savoy. Has peculiarly curled and crumpled dark green foliage. A robust grower. Highest quality.

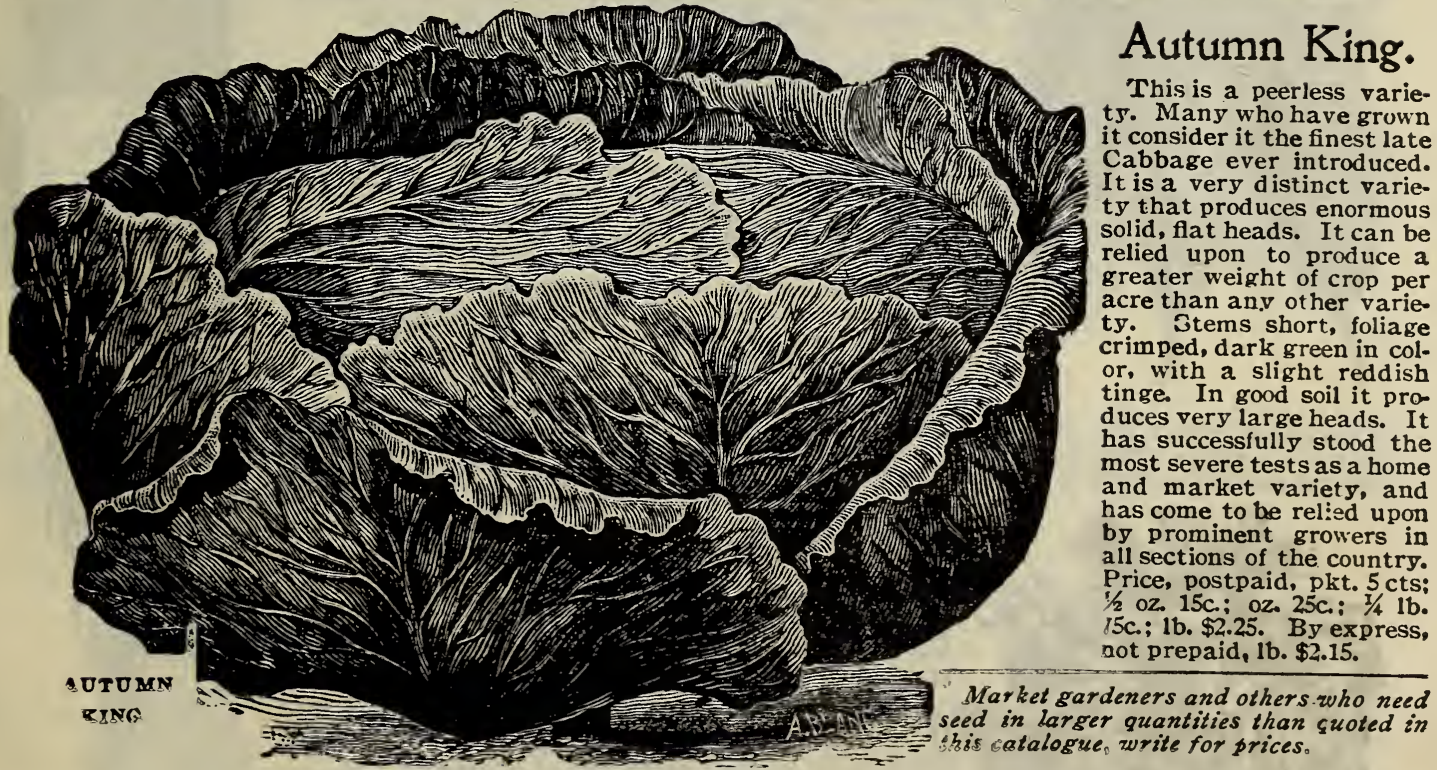

"OUALITY" When we speak of "quality" we do not mean simply the power to germinate and grow. It has a mich wider meaning, for many seeds will grow. Quality is shown only by the high grade, perfection and quantity of the crop produced. The real "quality" in any particular variety or strain of seed is obtained only by painstaking care, on the part of the grower; who must, for a series of years, carefully "rogne" or cull put all plants that are not true to his ideal tn their characteristics. This takes constant vigilance on his part, but it insuras the plant producing a profitable crop. Unfortunately there are growers who are not thoroughly reliable along this line. If the strain is not good a perfect crop caunot be grown, even on the best soil. 


\section{Select Carrots.}

Carrots are not only desirable for table use, but people are beginning to learn their great value for feeding stock. They are considered superior to Beets, Turnips and Parsnips for that purpose. The long White Belgian and Mastodon are the most valuable. We contracted with a leading French grower to supply us with the best seed, and do not hesitate to guarantee our seed equal to the best on the market.

CULTURE.-For early table use sow as soon as ground can be worked in the spring, in drills 15 inches a part, covering one-half inch; thin out to 3 or 4 inctes apart. A light sandy loam, deeply tilled, is best. Carrots require from 12 to 15 days to germinate. Firming ground after sowing will hasten germination.

Each packet of Carrots will contain one quarter ounce; sufficient for 40 to 50 feet of drill. Three pounds will sow an acre in drills two feet apart.

\section{Oxheart or Guerande.}

This is one of the most popular and valuable varieties either for family use or market. Intermediate between the Half Long and Short Horn varieties, attaining a diameter of three to four inches at the top. Always of good shape and rich orange color. Flesh finegrained, with little or no core. Truly a superb variety. Price, postpaid, packet 5c.; ounce 10c.: $1 / 4$ pound $25 \mathrm{c}$. pound, $75 c$. By express, not prepaid, pound $65 \mathrm{c}$.

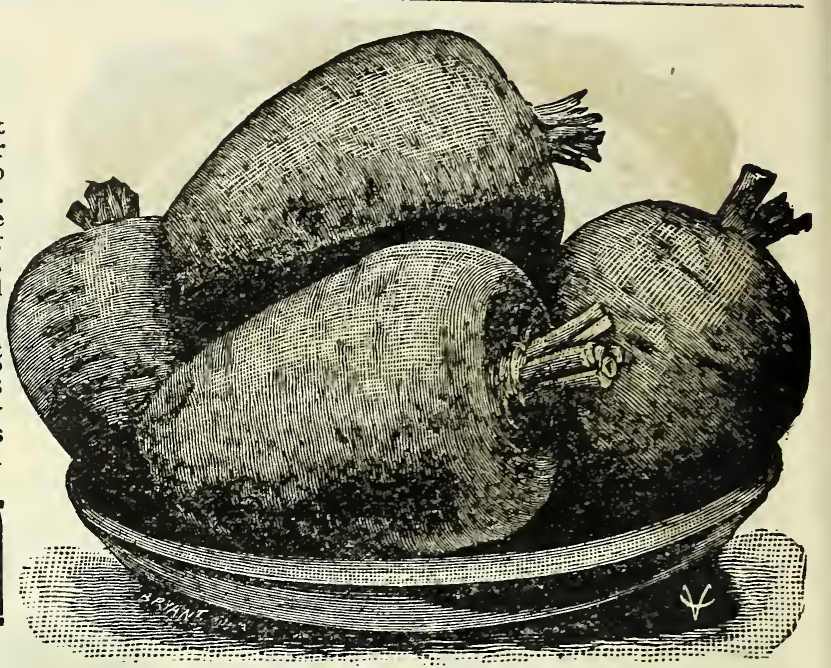

OXHEAKT, OR GUERANDE CARROT.

\section{Improved Long Orange.}

The most popular of the older sorts for stock. Roots large, long, tapering: rich orange; free from side roots. Fine winter sort; largely grown for market. Packet $5 \mathrm{c}$. oz. 10c.; $1 / 4$ lb. $25 \mathrm{c}$; 1b. $75 \mathrm{c}$. By express, $1 \mathrm{~b} .65 \mathrm{c}$.

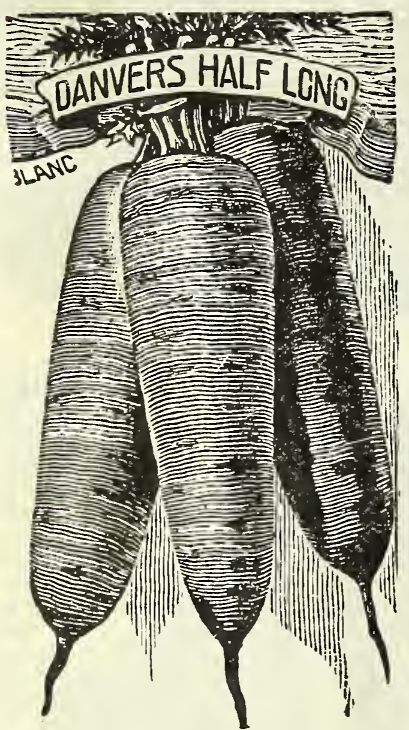

\section{Early Scarlet Horn.}

The favorite extra early variety for table use. Color, orange scarlet, fine-grained and agreeable flavor. Tops small, short stump-shaped roots: well adapted to shallow soils. Pkt. 5c.. oz. 10c.; 1/4 1b. 25c.; 1b. 75c. Express, 1b. 65c.

\section{Danver's Half Long.}

A popular and standard old variety; dark orange color. Very smooth and handsome; in form between the Oxheart and Long Orange. Wonderfully productive; under special cultivation it has yielded from 16 to 18 tons per acre. One of the finest varieties in cultivation. Price, packet 5c.; oz. 10c.. 1/4 lb. 25c.; 1b. 75c. By express, $1 \mathrm{~b} .65 \mathrm{c}$.

\section{Intermediate, or St. Vallery.}

A fine late variety for table use or for stock. It forms very large, symmetrical, smooth roots about 12 inches long. Color, deep orange; qualit y excellent. Tops small. Pkt. 5c.; oz. 10c.; 1/4 1b. 25c.; 1b. 75c. By express, 1b. 65c。

\section{Mastodon Stock Carrot.}

One of the best for stock feeding. This is one of the heaviest cropping Carrots grown, and probably yields more tons per acre than any other sort. The flesh is white, crisp and solid, very sweet in flavor and is eagerly eaten by stock. It differs from White Belgian in shape, the roots being shorter and heavier at the shoulder. An important feature is that they are easily gathered and do not break in pulling and storing. The roots frequently measiure 10 to 15 inches in circumference and from 18 to 20 tons per acre is not an extra vagant claim as to yield. Pkt. 5c.; oz.10c.; $1 / 4$ 1b. 20c.; 1b.55c. Express, 1b. 45c.

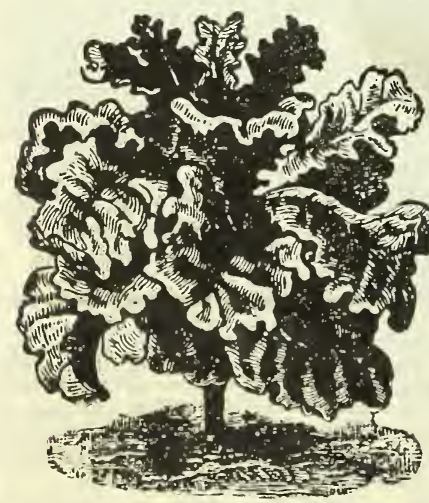

Long White Belgian. For stock. Pkt. $5 \mathrm{c} ; \mathrm{oz}$. roc.

\section{Collards.}

CULTURE. Sow like Cabbage during June, Juis and August. Transplant when a few weeks old to 2 foot apart in the row. Cultivate frequently. One ounce of seed will produce about 2,000 plants.

Georgia Creole. A very popular vegetable in the South. it belongs to the Cabbage family and forms a large mass of leaves on a tall stem, instead of a solid head. It is a very sure crop and a ffords an abundant supply of food for both man and beast. Price, per packet of $1 / 4$ ounce, 5 cents; ounce 10 cents; $1 / 4$ pound 25 cents; pound 75 cents. By express, pound 65 cents.

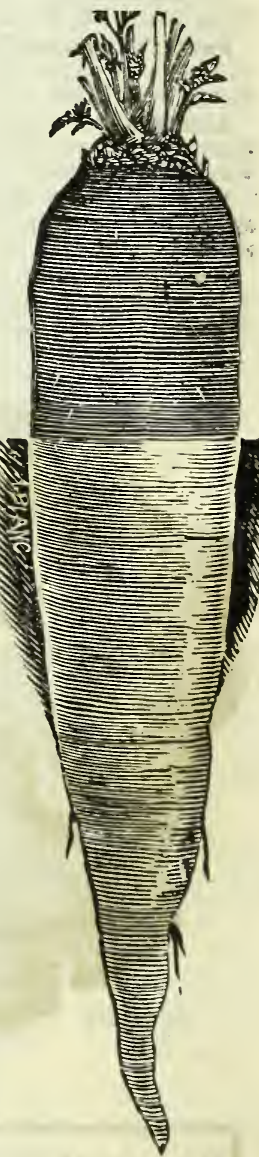

LONQ WRITE BELGIAN.

CARPOTS AND BEETS FOR STOCK No crop pays the stockman CARROTS AND BEETS FOR STOCK, better than Carrots and Beets. In comparative value 300 pounds of roots equals 100 hund red pounds of hay. Some dairymen claim that a bushel of Carrots and a bushel of Corn are worth more than two bushels of Corn. Together they form a balanced ration : singly

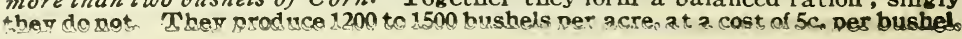




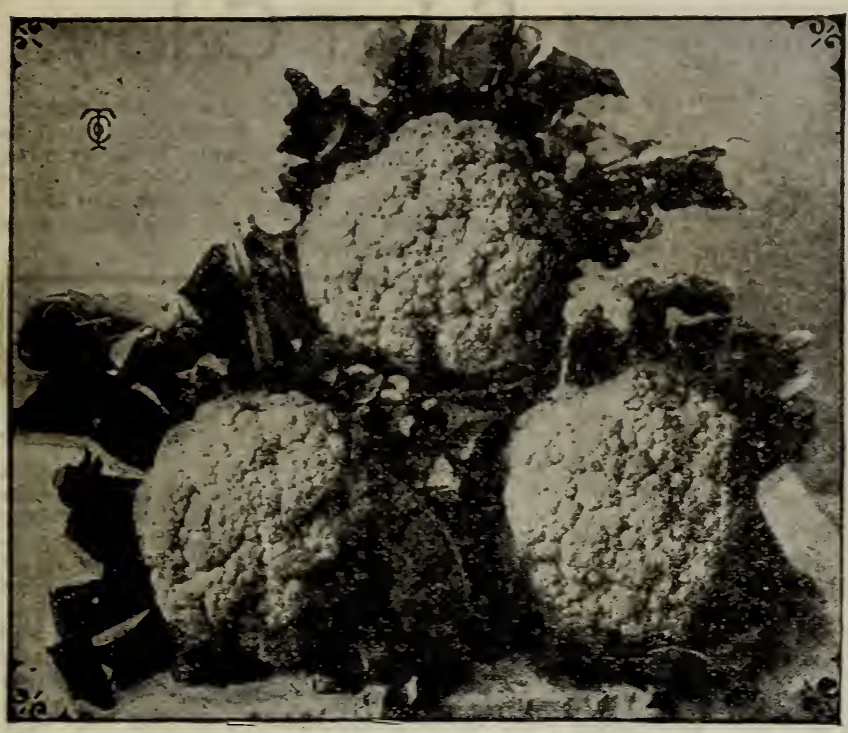

EARLY STOWBALL

\section{Cauliflower.}

CULTURE.-For spring and early sumner crop, sow during March and A pril in hotbed, transplanting to cold frame when large enough. Set in open ground when danger of hard freezing is over. Soil and cultivation same as for Cabbage. Pin or tie the leaves together after the head or "flower" has begun to forın: this will insure whiteness.

Each packet of Cauliflower will contain 200 seeds. One ounce will produce about 2,000 plants. 8,500 plants per acre.

\section{Early Favorite.}

This is a splendid variety. It is very ear15 , exceedingly hardy, easily grown, and perhaps the best sort for inexperienced growers, as it will head under conditions in which many sorts would fail. Forms large heads, which, though inclined to be slightly free, are crisp, tender and of fine qualit5. Without doubt, the best low-priced variety in the market. Years of experience has convinced us that it is the hardiest variety in cultivation, and it keeps in condition for use a long time. Price, postpaid, packet, 5 cents; $1 / 4$ ounce 40 cents.

\section{Early Snowball.}

This still holds its place as the most popular variety on the market. The seed we offer is grown for us by a Cauliflower specialist in Denmark. It is the result of long and careful selection. It is not quite as early as Early Dwarf Erfurt, but produces uniformly regular, even, close heads of large size. Whether for market or home use it can alwass be relied on. It is poor economy to buy cheap Cauliflower seed: a few cents difference in the price of a packet of seed may mean many dollars' difference in the crop. Price, packet 15 cents; $1 / 4$ ounce 75 cents.

\section{Early Dwarf Erfurt.}

This is the earliest first-class Cauliflower, and one of the best for general purpose. It is smallleaved, of dwarf, compact habit, producing ver 5 large, close, compact heads. It grows about 15 inches high, and in ordinary seasons every plant will produce a fine marketable head. More dwarf and earlier than Early Snowball. Price, packet 10 cents; $1 / 4$ ounce 60 cents.

Gentlemen: "We have patronized several prominent Seedsmen. With the same care and attention w'e find that Templin's Seeds far excel all others, both in quantity and quality. They have always given entire satisfaction. rours truly.

given entire satisfaction. SETH THOMPSON.
MrS. SETH

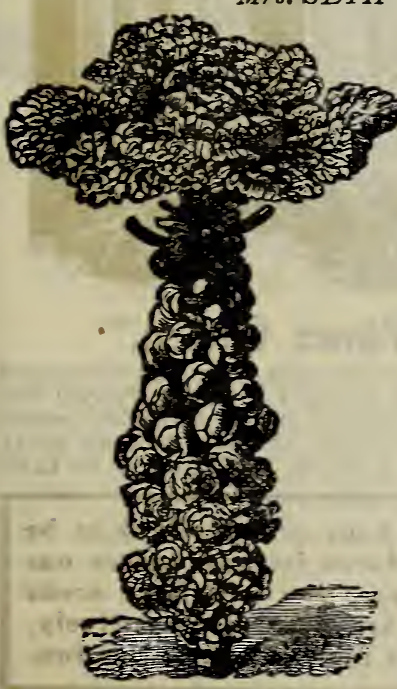

Brussels Sprouts. but not so well known in A merica most delicious vegetables. Of vers eass growth ous small heads resembling miniature cabbage. The sprouts are used as greens, and become very tender when touched $b 5$ the frost. Sow in Mas and treat same as winter cabbage. $1 / 80 z, 5 c ; 1 / 20 z, 10 c ; 0 z, 15 c ; 1 / 41 b, 40 c ; 1 b . \$ 1.30$. Exp. $1 b . \$ 1.40$.

\section{Large Rooted Chicory.}

In Europe the roots are dried and prepared quite extensiveIF as a substitute for coffee. Sow early in the spring; thin out to five inches apart. Dig roots in the fall, slice thin and dry in an evaporator. Roast brown like coffee. Price, $1 / 40 z$. pkt. 5 cts; $1 / 2$ oz. 10 cts; ounce 15 cts; $1 / 4$ lb. 35 cts; pound $\$ 1.00$.

\section{Cress or Pepper Grass.}

A small-growing, fine foliaged plant, of the easiest culture. An excellent flavoring for salads. Sow thickly in drills, early in the spring and at intervals throughout the season. Use while sougg and tender. Pkt. 5 cts; $0 \mathrm{z} .10 \mathrm{cts} ; 1 / 41 \mathrm{lb} .20 \mathrm{cts}$.

\section{Double Curled Chervil.}

Worthy of more general use for flavoring and garnishing. This varietr is more beautiful than Parsler. Readr in six to ten weeks from sowing. Sow early in spring, transplant to one foot apart. Pkt. 5 cents; $0 z .10$ cents; $1 / 4$ pound 25 cerits.

Try the new and standard varieties offer. BRUSSELS SPROUTS.

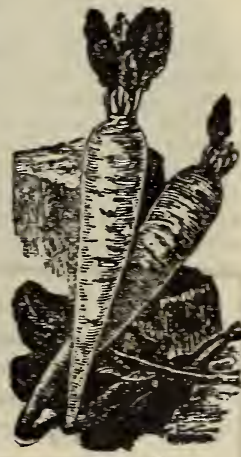

CBICORY. 


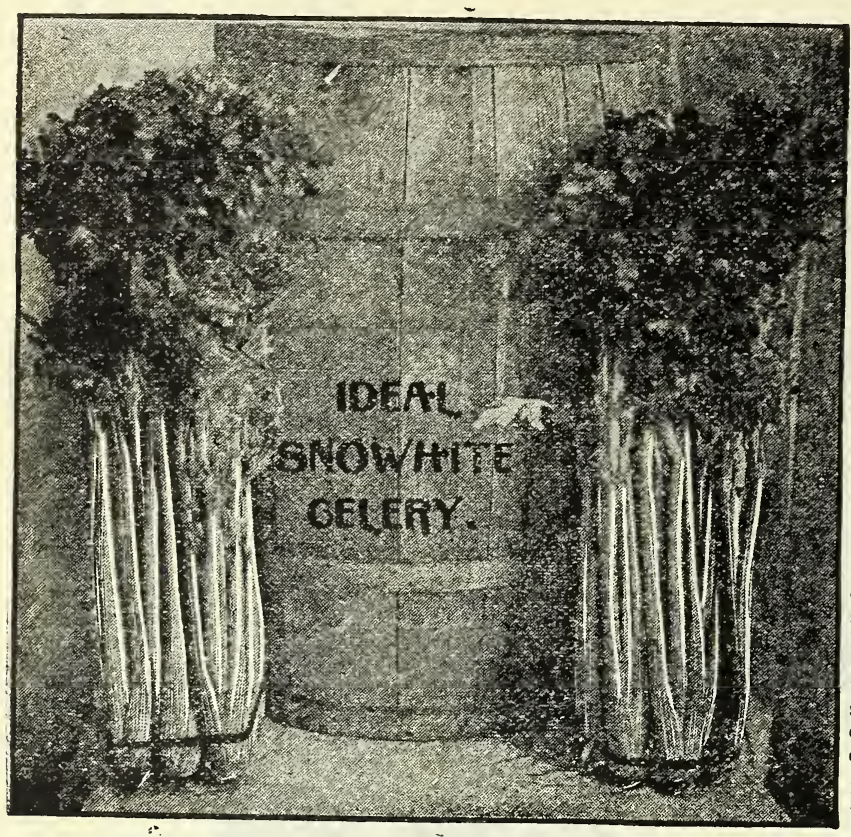

\section{Select Celery.}

CULTURE. - Sow thinly and cover lightly. Keep constantly moist. Ample time must be given, as the seeds are slow to germinate. Our book, "THE FAMILY GARDEN" gives very complete instructions for growing Celery. Price, 25 cents each, or given free with a $\$ 1.00$ order, if you ask for it.

Each packet of Celery seed will contain 1-8 oz.; sufficient to grow 400 to 500 plants One ounce will produce about 3000 plants.

\section{"Ideal" Snow-White Celery.}

This is a grand new Celery. It is without a rival in beauty of color, vigor of growth, ease of blanching, size, richness of flavor, crispness and purity. It is equal to Golden Self-Blanching in its robust, compact and sturdy habit of growth and ease of blanching. Free from strings and pithiness. The accompanying illustration gives an idea of its large size and general appearance. Single stalks sometimes weigh two pounds or more. It will certainly supercede the White Plume, as it is more vig. orus, larger and more true to type, and rich. er in flavor. To all its excellent qualities is added the snow-white coloring of the White Plume. Price, 5 cents per packet: ounce $40 \mathrm{cts}$ $1 / 4$ lb. $\$ 1.00$; 1b. $\$ 3.00$. By express, 1b. $\$ 2.90$.

\section{Evans' Triumph.}

An excellent variety, and one of the best keepers, Stalks very large and solid, very crisp, of finest texture, and possessing real nut-like flavor. It is worthy of first place as a late Celery. We highly recommend it as it possesses great merit for the home or market. Pkt. 5 cents: our.ce 20 cents; $1 / 4$ pound 60 cents; pound $\$ 2.00$. By express, pound $\$ 1.90$.

\section{Giant White Solid.}

An excellent late variety, growing to very large size. The tall stalks a re broad, very solid, and blanch pure white. Foliage dark, rich, healthy green. An excellent keeper. When properly grown it is one of the finest Celeries, both in appearance and quality. Packet 5 cents; ounce 20 cents; $1 / 4$ pound 60 cents; pound $\$ 2.00$. By express, pound $\$ 1.90$.

\section{Pink Plume.}

The stalks of this beautiful Celery are of a clear, creamy-white, shaded and tinted delicate pink. A sport from the popular White Plume, and retains the white variegations in the foliage. It has the long keeping qualities for which the pink and red varieties are noted. In quality it is solid, crisp, tender and sweet. In this respect it is superior to many of the green varieties. Those who really desire a first-class Celery will make no mistake by planting Pink Plume. Packet 5 cents; ounce 20 cents: 1/4 pound 60 cents; pound $\$ 2.00$. Express, pound $\$ 1.90$.

\section{White Plume.}

Each year adds to the popularity of this variety. Owing to its foliage being variegated with white, it in a measure blanches itself without being planted in a trench, by simply tying up the stems closely. This distinct Celery is usually grown as an early variety, although it is a good keeper up to the holiday season. It is of excellent quality, althougis we think it not quite equal to green and golden varieties, though
it is much less trouble to grow. Packet 5 cents; ounce 15 cents; $1 / 4$ pound 50 cents; pound $\$ 1.75$. Express, 1 b. $\$ 1.65$. flavor. Pkt. 5 c: oz. 25 c; $1 / 41$ b, 75 c. 1b. $\$ 2.50$. Ex., Ib. $\$ 2.40$.

Order Early. It is greatly to your advantage to order early. Your order will then be Lrer filled before the great rush that begins about March Ist, and before our stock is broken by the heavy spring trade. As a further advantage, you will have seeds ready when the ground is first in condition to plant. All orders are filled consecutively. and usually promptly. Your orders, largo or small, will have our most careful attention. 


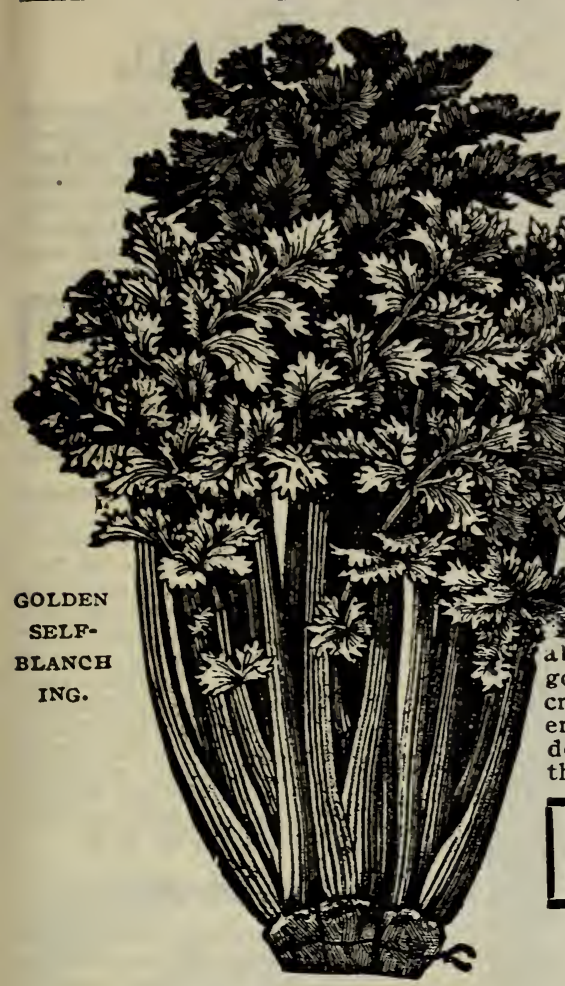

Celeriac.

This is an excellent vegetable. Where they have been tested they have proved to be a very profitable crop. HighIy esteemed either cooked in the same manner as beets, for fla voring soups, or sliced and used as a salad. Culture same as Celery except that it needs no

Giant Prague. Probably the largest and best variety grown. Roots large, globular and smooth. Keeps well for winter use. Pkt. 5c;0z. 20c; $1 / 4$ 1b. $60 \mathrm{c} ; 1 \mathrm{~b} . \$ 1.50$.

Turnip-Rooted. A well known old variety of great merit. Roots large, turnip-shaped, smooth. One of the finest for salads, flavoring of soups, etc. Packet 5 cents; ounce 20 cents; $1 / 4$ pound 60 cents; pound $\$ 1.50$.

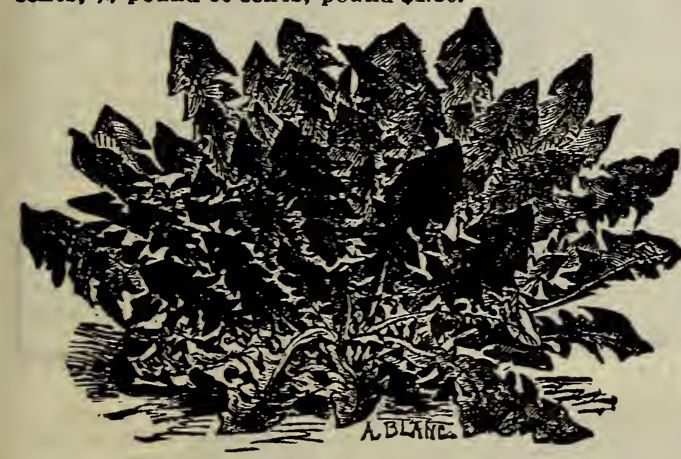

IM PROVED THICK-LEAVED DANDELION.

\section{Endive.}

CULTURE.-Used as salad. Sow seed in June and July-as a second crop-in rows 12 to 18 inches a part, and 12 inches in the row. Cover about an inch deep. Blanch by tying the leaves together. One $0 z$ to 300 feet of row; 5 pounds per acre.

Green Curled. Beautifully curled dark green leaves which blanch white, tender and crisp. Much used for garnishing.

White Curled. (Self-blanching.) Leaves pale green, large, crisp and tender; attractive, easily grown; can be gathered for use at any time.

Price of Endive, packet 5 cents: ounce 15 cents.

\section{Golden Self-Blanching.}

There is probably more Golden Self-Blanching Celery grown than of any other one variety. It is almost the only variet grown in the large Celery swamps for supplying the early (1) grown in one continuous field, and most of it is Go!den (It is of close, compact habit, stalks solid and crisp. The foliage and stalks are of a rich golden-yellow oolor, and the readiness with which they are blanched makes it invaluable for early family or market use. Packet 5 cents: unce $25 \mathrm{cts}$; $1 / 4$ pound $90 \mathrm{cts}$; pound $\$ 3.00$. Express, $1 \mathrm{~b}$. $\$ 2.90$.

\section{Dwarf Golden Heart.}

A valuable new variety produced by careful selection from A popular Golden Heart. It is of sturd $y$, heavy, but dwart abit: stalks thick, solid and of excellent quality; of a waxen golden-yellow when blanched, rendering it a most attractive and showy variety. Price, packet 5 cents; ounce 15 cents: $1 / 4$ pound 40 cents; pound $\$ 1.25$. Express, $1 b . \$ 1.15$

\section{Kalamazoo.}

There is more good Celery grown in the famous Kalamazoo Celery Fields than anywhere else in the country. This valuin color. It is of quick growth and compact habit. The autPacket 5 cents; ounce 15 cents; $1 / 4$ pound 40 cents; $1 \mathrm{~b} . \$ 1.25$.

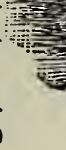

\section{.}

Improved Dandelion. Everybody likes to gather Dandelions in the spring for "greens," but few people know they can be successfully grown in the garden, and the cultivated variety is better than the wild. CULTURE. - Sow the seed in drills in early spring and thin out to six inches in the row and keep well cultivated and ee from weeds throughout the summer. The following spring will be ready for use. Cover the plants with a light mulch uring the winter.

Improved Thick-Leaved. This is a decided improvement ver the common varieties gathered in the field. It is a vig. orous grower, having heavy leaf-stalks and leaves. Packet 5 cents: $1 / 2$ ounce 20 cents: ounce 35 cents.
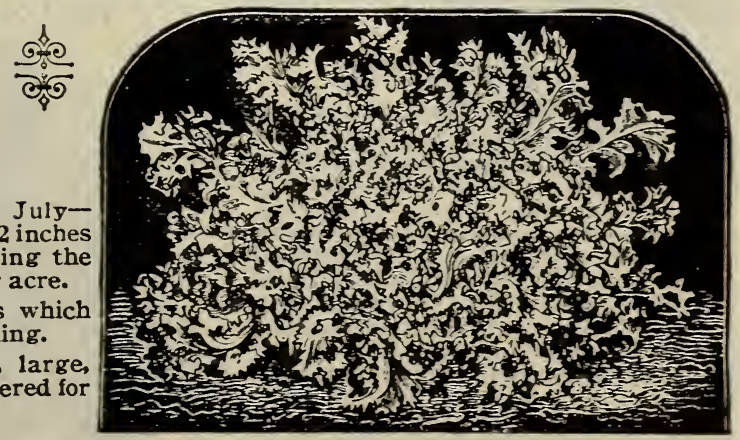

GREEN CURLED ENDIVE.

BY COMPARISON you will find that our prices are as low as any other reliable house. Quantity, quality and courteous treatment we guarantee. We please you or refund your money. 


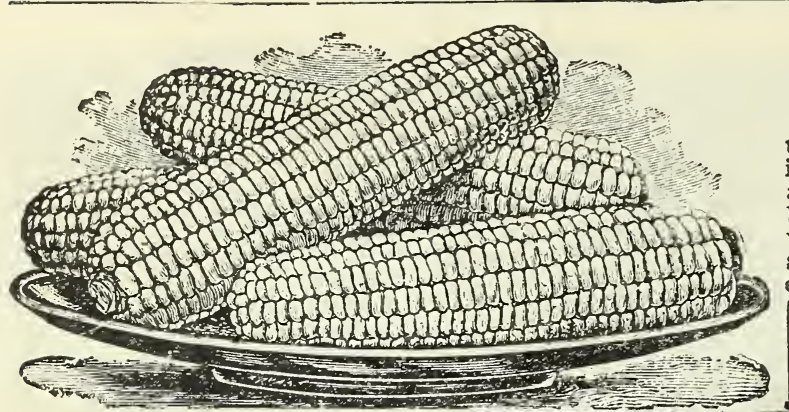

MAMMOTH WHITE CORY.

\section{Mammoth White Cory.}

This is claimed by the origina tor to be the earliest and best extra early Sweet Corn in existence. The ears are larger than the Cory, and usually appear two or even three on a stalk. The ears are 12-rowed, and are handsome and symmetrical, with no openings between the rows at the base; cob white. The grains are large and white, and of remarkably good quality for such an eariy variety. A splendid family variety, and unsurpassed for market, owing to its fine large ears and attractive appearance Price, pkt. $5 \mathrm{cts}$; $1 / 2$ pint $10 \mathrm{cts}$; pt. 20 cts; quart 35 cts. By express, quart $25 \mathrm{cts}$; peck $\$ 1.50$.

\section{Peep O’Day.}

A new variety of extraordinary earliness and superior sweetness, equaling the larger and later varieties. Wonderfully productive, owing to the fact that the stalks bear from two to three ears each. The originator claims for this variety that it sometimes yields almost double as much as other sorts. Very popular and profitable to market gardeners, owing to its earliness, productiveness and beauty. Pkt. 5c; 1/2 pt. 15c: pt. $25 \mathrm{c} ;$ qt. $40 \mathrm{c}$. Exp. qt. 30c; pk. $\$ 1.50$.

\section{Early Champion.}

A splendid variety producing ears 8 to 10 inches long and almost as early as the small-eared early varieties. Ears nearly as large as the Evergreen; pure white, 12-rowed, with white cob of medium size. Early Champion is very sweet and tender, and in every way possessing the highest quality. It is ver.y productive, usually producing two ears to the stalk. It is unsurpassed for the market gardener, owing to its large size and fine appearance. Among the earliest Sweet Corn. Pkt. 5 cts: $1 / 2$ pint 15 cts; pint 25 cts; quart 40 cts,
postpaid. By express, not prepaid, quart 30 cents; peck $\$ 1.25$.

\section{Early Evergreen.}

This, we believe, is destined to become one of the most popular varieties. It is very prolific, and matures its ears in from 60 tn 70 days, depending upon location and character of soil. The large, well filled ears command a quick sale in any market where there is a demand for really choice early Sweet Corn, and it is therefore of great value to market gardeners. It is unsurpassed in quality, and like Stowell's, remain in condition for use much longer than other va rieties, being therefore desirable for the home garden. It resembles the old Stowell's Evergreen, but is fit for use from one to two weeks earlier. Pkt. 5 cents: $1 / 2$ pint 15 cts: pint 25 cts; quart 40 cents. $\mathrm{By}$ express, quart 30 cents; peck $\$ 1.25$.

\section{Sweet Corn.}

CULTURE.-Sweet Corn should not be planted until the ground is quite warm, as it is liable to rot if planted in cold, wet soil. It is a good plan to plant at intervals of two weeks until July; you will thereby have Corn to use from July until October. Our, valuable 140 page bonk, "The Family Garden," gives full instructions for growing all kinds of veg-
etables, fruits and flowers. Free with a $\$ 1$. order.

Each packet of Sweet Corn will contain two ounces; sufficient to plant 40 to 50 hills; 1 quart will plant 500 hills; 8 quarts will plant an acre.

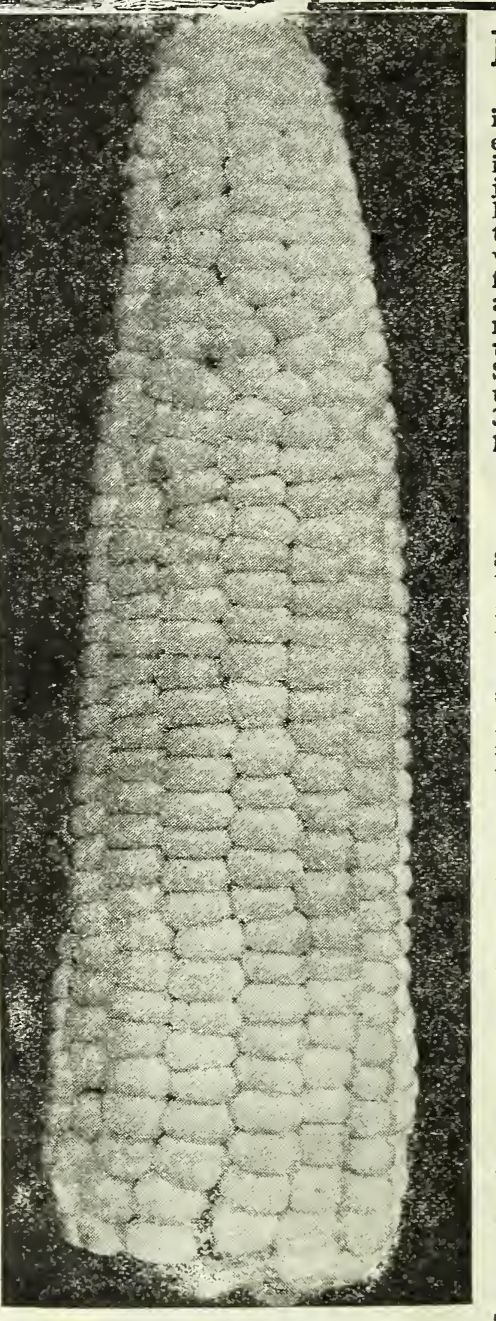

Kendel's Early Giant.

This is a distinct variety, possessing more than ordinary merit. The ears grow to very large size, measuring from 8 to 10 inches long, the majority having 12 rows. In color the kernels a re pure white and are very tender, sweet and palatable. It is very prolific, maturing its ears in from 60 to 70 davs. The large ears are very handsome and command a ready sale in any market where there is a demand for really choice Sweet Corn. It has become very popular. Pkt. 5c; 1/2 pt. 10c; pt. 20c; qt. 35c., postpaid. By express, not prepaid, quart 25 cents; peck $\$ 1.25$.

\section{First of All.}

This is the earliest Sweet Corn grown. It is a selection from the Extra Early Cory, but much sweeter and coming in a few days earlier. Ears medium size, well filled with large grains. It is a very quick grower, quite productive and a splendid money malier for market gardeners, Ears often 8 inches lon8. Pkt. 5c: $1 / 2$ pt. $15 \mathrm{c}$; pt $25 \mathrm{c}$ : qt. $40 \mathrm{c}$. By express, q t. 30 cts; peck $\$ 1.25$.

\section{Premo.}

No Sweet Corn was erer introduc. ed that gave such general satisfaction as Premo. It not only combines all the merits of the leading early varieties, but is really superior to them in size, qualit $y$ and yield. It produces two well developed ears to the stalk. Many growers report mature Corn ready for use in 57 to 60 days from time of planting. Earlier by a week than any other variety. Pkt. 5 cts; $1 / 2$ pt. $15 \mathrm{c}$ : pt. $25 \mathrm{c}$ : q t. 40 cts. Express, qt. 30 cts; peck $\$ 1.50$.

TEMPLIN'S GOLDEN HONEY.

See page 7 for this grand novel-

ty. It excels all other varieties

in richness, delicacy of flavor and

superior table qualities.
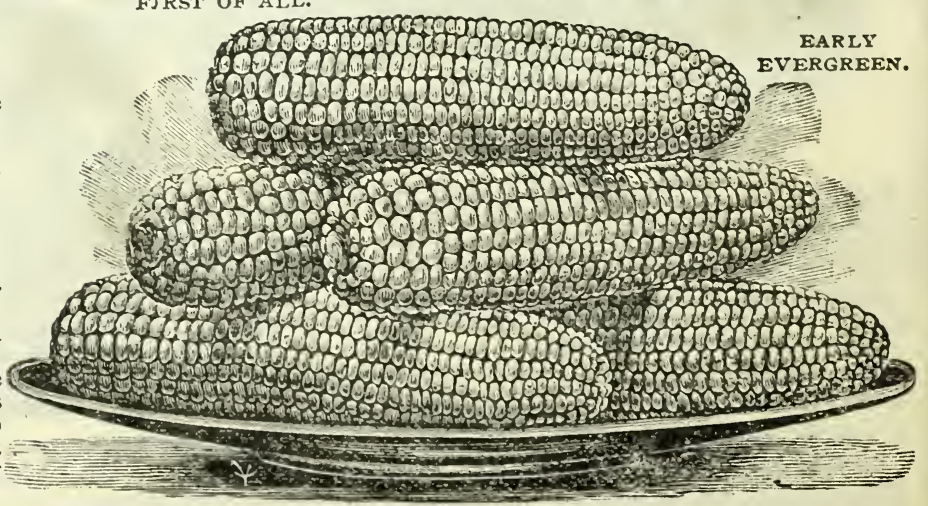


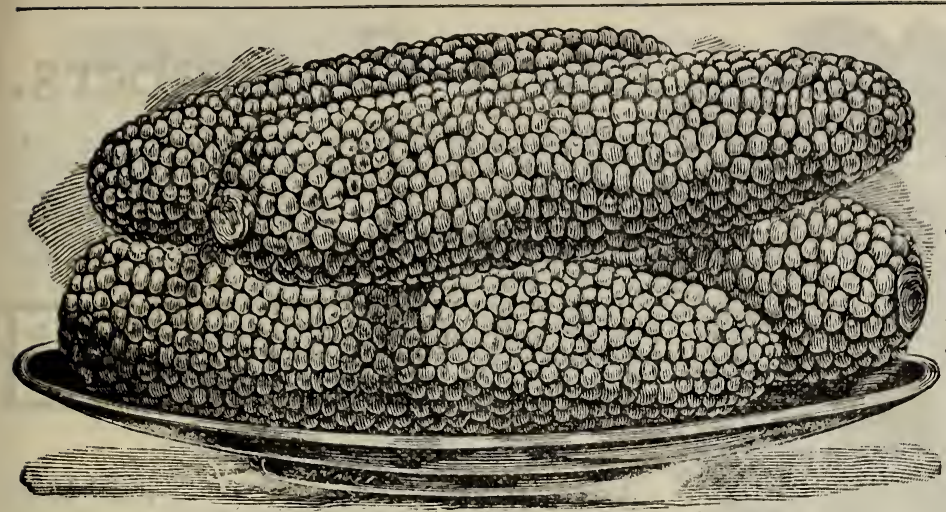

Country Gentleman.

This is one of the most popular varieties grown. Mid-season; ears quite large and frequently produced three on a stalk. The grains are placed irregularly but very closely on the cob, which is remarkably small, giving great depth to the compressed grains. The accom panying illustration is an exact representation of this popular variety when in the roasting-ear stage. Plkt. 5 cts; $1 / 2$ pt. $15 \mathrm{cts}$; pt. 25 cts; qt. $40 \mathrm{cts}$. By express, quart 30 cents; peck $\$ 1.50$.

\section{Stowell's Evergreen.}

Every market gardener and every private gardener in the land knows this grand old variety. It is now recognized as a standard main-crop variety. The ears are of large size, grains deep, excepCOUNTRY GENTLEMAN.

\section{Metropolitan.}

This is a fine new Sweet Corn that matures just after the First of All. It combines the essential features of earliness and fine quality to a marked degree. It is truly a fine type of early, or semi-early Sweet Corn. The plant is of very distinct type, being very strong, 5 to 6 feet high, each stalk bearing two or three ears that are 8 to 10 inches long, 10 to 12 rowed, low on the stalk; ears well filled to the tip with large, deep grains. It possesses that exquisite sweet flavor so well known in the larger and later varieties. Pkt. $5 \mathrm{cts} ; 1 / 2$ pint $15 \mathrm{cts}$; pint $25 \mathrm{cts}$; quart $40 \mathrm{cts}$, postpaid. By express, quart 30 cents; peck $\$ 1.50$.

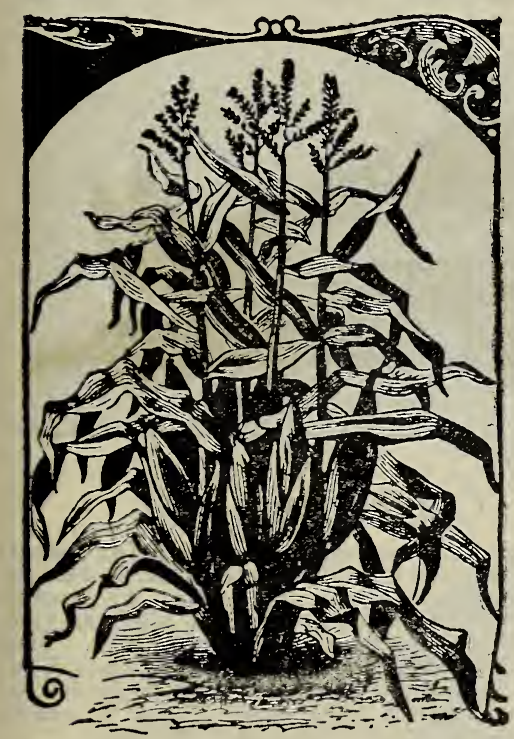

MAPLEDALE PROLIFIC POP CORN.

\section{Selected Pop Corn.}

CULTURE-Pop Corn, like all other corn, should not be planted until all danger of frost is past. Plant in hills 2 feet apart, rows $2^{1} / 2$ to 3 feet apart; 4 to 6 grains in each hill and cover with two inches of soil. When a few inches high thin out to three stalks per hill. Give frequent and shallow cultivation.

Each pkt. of Pop Corn will contain 2 ozs; sufficient for 100 hills; 4 to 5 gts. per acre.

\section{Mapledale Prolific.}

Considered the most prolific variety. The ears are often 8 to 10 inches long, well filled with bright, handsome white grains. It is a vigorous grower, attaining a height of 6 feet, and producing from 2 to 3 ears on each stalk. For popping it is unsurpassed, the popped grains being large, pure white and of delicious flavor. The most wonderfully prolific variety ever introduced. We can heartily recommend it to our patrons. Pkt. 5 cts; pint 20 cts; quart 35 cts, postpaid. By express, quart 25 cts; peck $\$ 1.10$.

\section{Golden Queen.}

This is probably the most beautiful variety of Pop Corn grown. The ears are unusually large kernels very large, deep, bright golden yellow in color. It pops perfectly white and a single kernel will expand to nearly an inch in diameter. It is a wonderfully prolific variety, producing from 3 to 4 ears on a stalk. We can heartily recommend this variety. Price, packet 5 cents; pint 20 cents; quart 35 cents, postpaid. By express, not prepaid, quart 25 cents; peck $\$ 1.10$.

\section{Improved White Rice.}

This is, without doubt, one of the most satisfactory varieties of Pop Corn grown. The ears are of medium size, three to four on a stalk. Kernels round, sharp poirted; color, transparent white. When popped the grains are large, pure snow-white, very crisp, tender and of most excellent flavor. Price, packet 5 cents; pint 20 cents; quart 35 cents, postpaid. By express, not prepaid, quart 25 cents; peck $\$ 1.10$.

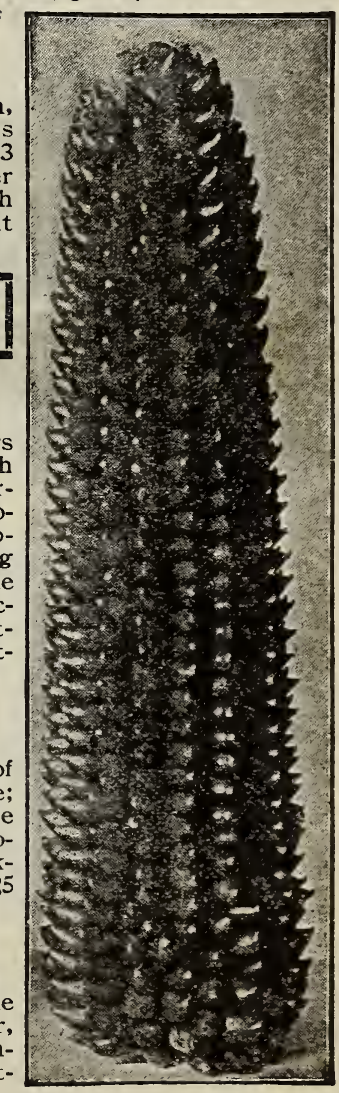

WHITE RICE.

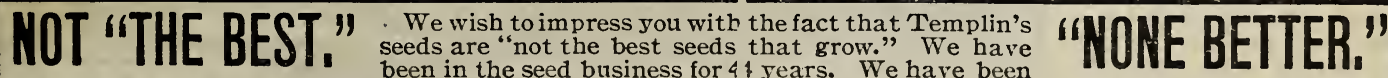
personally acquainted with the leading seedsmen in Ameri a, and are free to acknowledge that there are other seedsmen who are just as conscientious as we are, and who actually send their customers as good seeds as Templin's. While we know other seedsmen personally, we also know where their seeds are grown, and know the growers personaliy. Therefore, we can decla re, without fear of cuntradiction, that

There is no seedsman, under any circumstances whatever, who can and will furnish you with better seeds than those offered in this catalogue. We make this unqualified statement for new readers of our catalogue. Our patrons know the high quality of Templin's Seeds. 


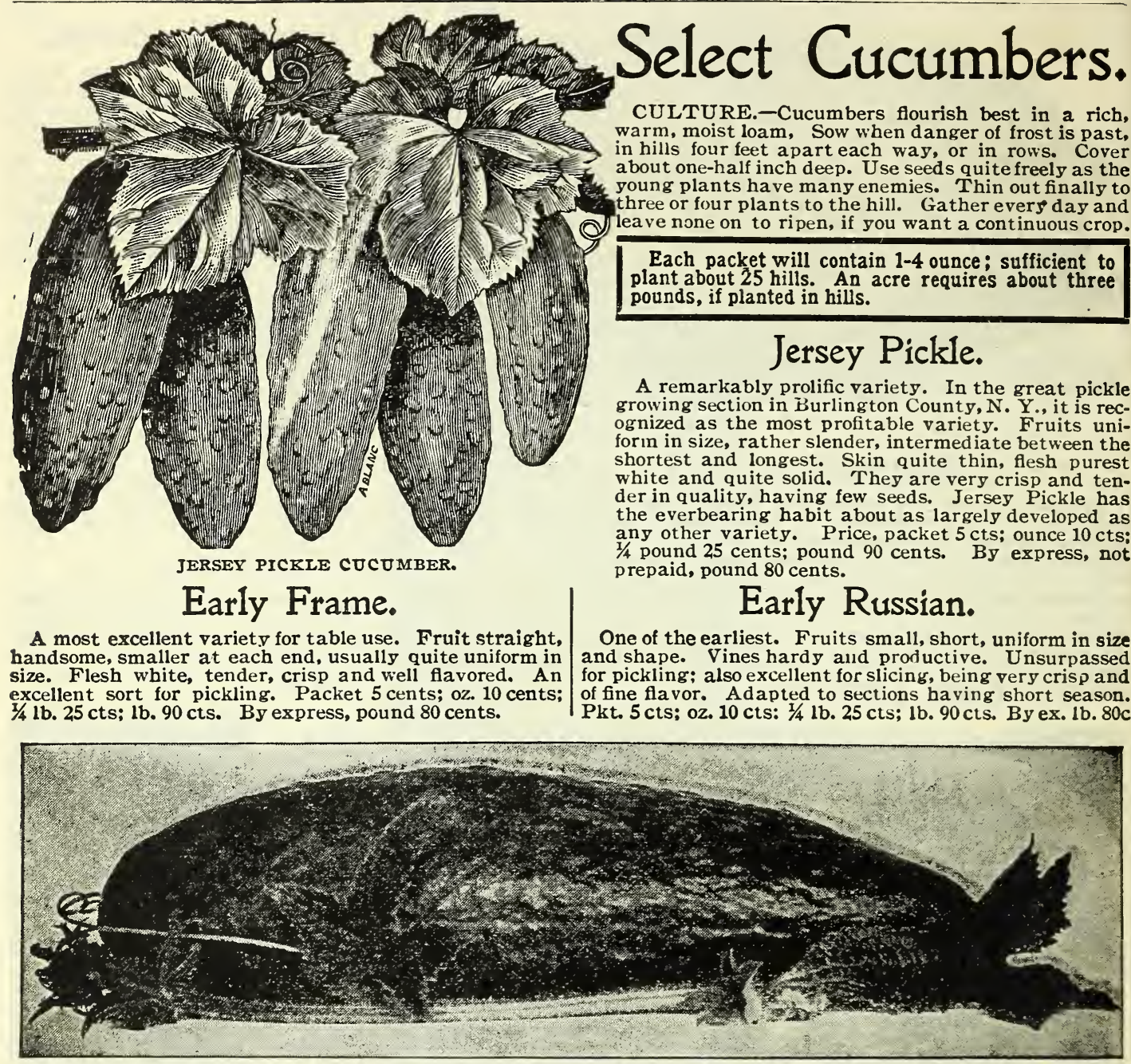

JERSEY PICKLE CUCUMBER.

\section{Early Frame.}

Improved Long Green.

This is a decided improvement on the old Long Green, obtained by years of very careful selection. Fruits 10 to 12 inches long, firm, crisp, and of fine quality. A superior variety for those who want a long, dark green Cucumber. Most excellent for pickles; when mature they make the very best sweet pickles. Our seeds are selected from a strain that is uniformly long and of excellent shape Packet 5 cents; ounce 10 cents: $1 / 4$ pound 30 cents; pound 90 cents. By express, pound 80 cents.

\section{Arlington White Spine Cucumber.}

The earliest, most shapeIy and productive variety of the White Spine type. Fruits very regular in outline, uníform in size; a verage 7 to 8 inches in length, and always very straight. Flesh white, crisp and solid, with comparatively few seeds: flavor most excellent. The white tips of the spines add much to their appearance. We heartily recommend it. Our seeds are of the finest strain. Pkt. $5 \mathrm{c}$ : $0 z, 15 \mathrm{cts} ; 1 / 4$ lb. $25 \mathrm{cts}$; $1 \mathrm{~b}$. 90 cts. By express, $1 \mathrm{~b} .80 \mathrm{c}$

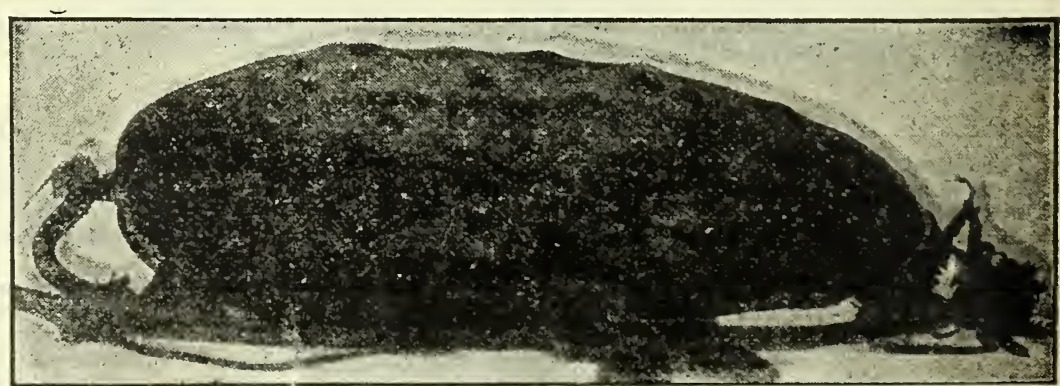

See page 7 for the New Cucumber, "D AVIS PERFECT." The best variety for Slicing.

PICK THEM CLEAN If you want the best possible results from your Cucu inber vines, pick the fruits clean. Do PIGK THEM GLEAN, not leave a single one on a vine to ripen, as it quickly exhausts the vine so that it will sonn cease bearing. Also handle the vines carefully and do not tramp on them or break down the leaves. 


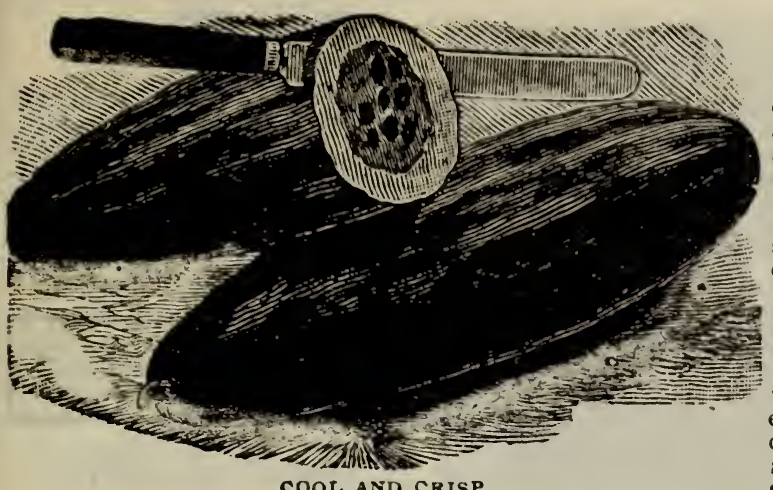

Cool and Crisp.

A very valuable variety. It is very early and ex. ceedingly productive. At the picking age the fruits are very straight, long, slim, uniform in thickness: and until nearly full size they are dark green, or almost black in color. It is one of the best for pickling: also fine for slicing. When full grown it is of good size and exceedingly crisp and tender. Everything considered this is a very desirable variety. Pkt. 5 cts: oz. 10 cts: $1 / 4$ lb. 30 cts; $1 \mathrm{~b} . \$ 1.00$. Express, $1 \mathrm{~b} .90 \mathrm{cts}$.

\section{Thorburn's Everbearing.}

The peculiar merit of this grand variety is that the vine continues to bloom and bear its fruits during the entire season, whether the ripened fruits are all picked or not. It is unique in this, as with most varieties the growth will be checked and the vines become exhausted. The fruits are of medium size, rich dark green in Early Cluster. color, a veraging from four to six inches in length by an inch and one-half in diameter. Frui's of every age and size, also blossoms, may be found on a single vine; indeed, they bear continuously until killed by frost. It is enormously productive and a general favorite where known. There are many new varieties, so called, being introd uced every season; here is an old variety that is equal to any of them. Pkt. 5 cents; ounce 10 cents: $1 / 4$ pound 30 cents; pound $\$ 1.00$, postpaid, Bs express, pound 90 cents.

A very popular variety that is certain to please all who grow it. It is remarkably prolific, producing its fruits in clusters. Fruits small, of uniform size and shape. One of the most satisfactory varieties for pickling. Our seeds are of a very superior strain. Packet $5 \mathrm{cts}$; ounce $10 \mathrm{cts}$ $1 / 4$ pound 25 cents; pound $90 \mathrm{cts}$. By express $1 \mathrm{~b} .80 \mathrm{cts}$.

\section{Chicago Pickling.}

A grand old variety that is prefered above all others by many of the largest pickling establishments in Chicago and elsewhere. It is also very largely grown by market gardeners, and possesses great merit for the family garden. It is a good vigorous grower, The fruits are of medium size a nd length, pointed slightly at each end, with large and prominent spines. Color, a deep green. It combines all of the good qualities of an early variety, and in addition possesses all the essentials for an all-purpose $\mathrm{Cu}$ cumber, The seeds we offer are of the very finest strain and are sure to give satisfaction, Price, packet $5 \mathrm{cts}$; ounce 10 cents: $1 / 4$ pound 35 cents: pound $\$ 1.10$; postpaid. By express, pound $\$ 1.00$.

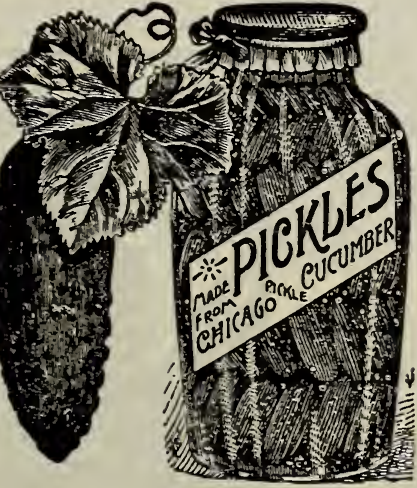

Boston Pickling.

Sometimes catalogued as Green Prolific. Fruits very uniform in shape. Vines very productive, having yielded 200,000 per acre. It is a great favorite with pickle growers and market gardeners. Pikt. 5 cts; oz. 10 cts; $1 / 4$ lb. 25 cts; 1 b. 90 cents. By express, pound 80 cents.

\section{Fordhook Pickling.}

The thinness of skin, crispness and tenderness of the flesh combine to make it one of the best varieties for family use. The skin is free from toughness when first picked. Because of vigor, productiveness and uniform size. it is a splendid sort for pickling. Pkt. $5 \mathrm{cts}$. 0z. 10 cts: $1 / 4$ lb. 30 cts; 1b. 90 cts. Express, 1b. 80 .

\section{Japanese Climbing.}

Entirely distinct, being a real climber that does best on a trellis or fence. Fruits large, smooth, dark green, of excellent quality. Flesh white. EspeciaHy fine for slicing. Pkt. 5 cts. 0z, 15 cts; $1 / 4$ lb. 35 cts; lb. $\$ 1.10$. By ex. 1 b. $\$ 1$. 5 cents; ounce 15 cents; $1 / 4$ ponnd 50 cents; pound $\$ 1.50$,

\section{Nichol's Medium Green.}

One of the best general pur pose varieties. The joung fruits are very symmetrical in shape, deep green in color and very crisp; for early forcing and slicing there is none better. It is exceedingly pro ductive, of medium size, and always straight and smooth. Very largely used in pickle factories, and also for home and market gardens. Pkt. 5 cents. oz. 10 cts: $1 / 4$ lb. 25 cts: Ib. $90 \mathrm{cts}$. Express, 1b. $80 \mathrm{cts}$

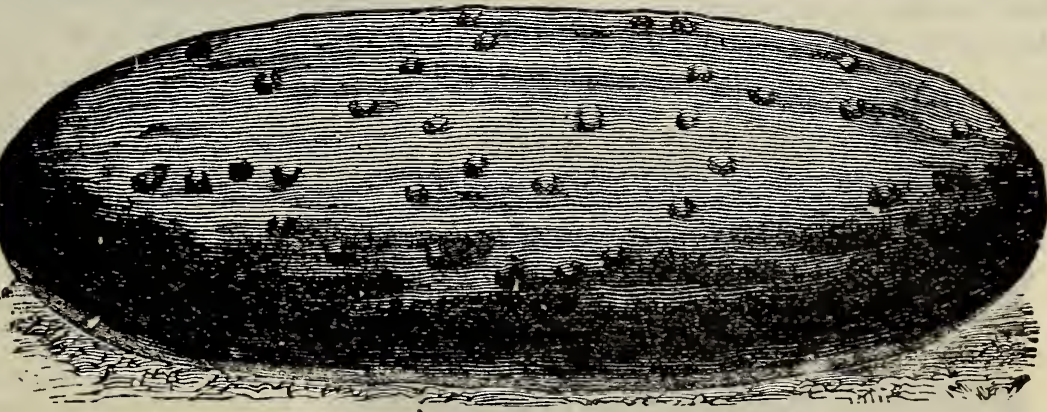

NICHOL'S MEDIUM GKEEN CUCU MBER.

\section{A Comparison that will Interest all Seed Buyers.}

The prices in the first column of this CoMPARIson TABLE are taken from our catalog of 1908. The others are the prices asked by three other prominent mail-order Seedsmen. The table show's very conclusively that at our prices, of Five Cents, Net, we actually sell Seeds cheaper than our competitors. And "There are None Better."
Red Valentine Bean.
Big Boston Lettuce.

Golded Carmine Bean. - - 5

Winningstadt Cabbage.

Golden Self-Blanching Celer 5 . - 5

Stowell's Evergreen Corn. - - 5

White Spine Cucumber. - - - 5

Percent of Discount offered.

Net cost to Patron. 30

$\begin{array}{rrr}10 & 10 & 10 \\ 10 & 10 & 10 \\ 10 & 5 & 5 \\ 10 & 10 & 10 \\ 10 & 10 & 10 \\ 10 & 5 & 10 \\ 60 & 50 & 55 \\ 33 & 20 & 00 \\ 40 & 40 & 55\end{array}$

Prize Taker Onion.

Gradus or Prosperity Pea.

Mammoth Chili.

Ponderosa Tomato.

Percent of Discount offered. - - 00

Net cost to Patron. 30

$\begin{array}{rrr}10 & 5 & 5 \\ 10 & 10 & 5 \\ 10 & 10 & 10 \\ 10 & 10 & 10 \\ 10 & 5 & 10 \\ 10 & 10 & 10 \\ 60 & 50 & 50 \\ 33 & 20 & 00 \\ 40 & 40 & 50\end{array}$

THE ABOVE SHOWS THAT THE "DISCOUNT" AND "PREMIUM" IDEA IS MISLEADING AND WRONG. 


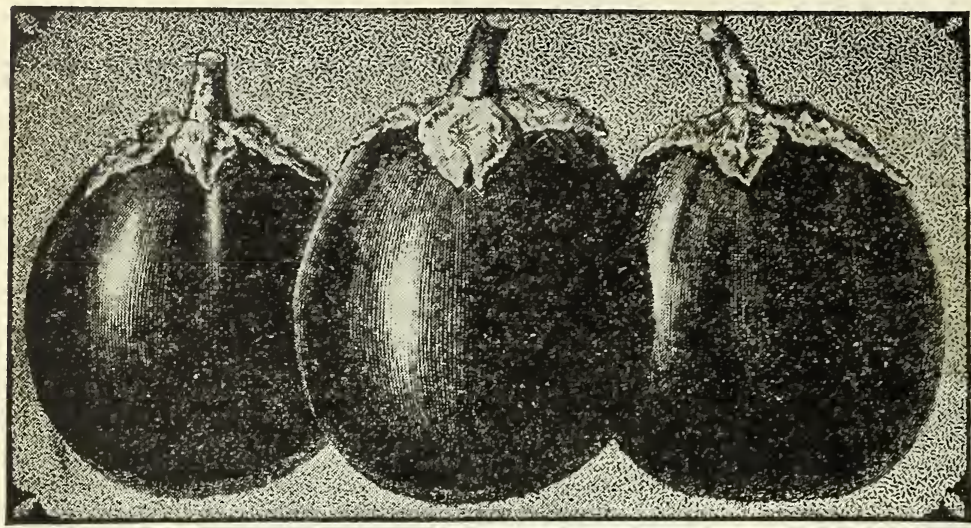

\section{Egg Plant.}

CUlture.-The Egg Plant being a warm climate plant requires heat, and should not be planted out until warm weather is assured. St art in a hot-bed, not too early in the spring. Set out in rows three feet apart, two feet in the row. The growth should not be checked by cold weatber after germination.

Each packet of Egg Plant will contain from 400 to 500 seeds. Eight ounces will plant an acre.

\section{Black Beauty.}

This new Black Beauty, or Cherry Black, originated in South JerBLACK BEAUTY VEGETABLE EGG. sey with a very prominent trucker,

\section{Improved New York Spineless.}

A splendid variety of vastly superior type; the plants sirablein color, being almost black, much like is very deare of low, stocky, branching habit and entirely free from Pekin. A verage weight two or three pounds. It is dwart spines. It is a very early and continuous producer of in habit, bearing its fruit close to the main stem. Price, handsome fruits of the largest size and finest quality. packet $5 \mathrm{cts}$; $1 / 2$ ounce $25 \mathrm{cts}$; ounce $45 \mathrm{cts}$.

They are very productive, plants usually bearing eight to ten immense fruits before being killed by frost. This variety is fully two weeks earlier than the original New York Purple. It may not be generally known, but such fruit as are large enough may be gathered and stored in a warm, dry place at the approach of frosty nights, they may thus be kept in good condition for several weeks. Price, packet 5 cents: $1 / 2$ ounce 20 cents; ounce 35 cents.

\section{Black Pekin.}

A great fa vorite. Handsome, large, nearly round fruits, weighing from four to eight pounds. Blackish purple; flesh white, fine grained, excellent flavor. Matures very early. Very productive. Packet 5 cents; $1 / 2$ ounce 15 cents; ounce 25 cents.

\section{Ornamental Gourds.}

Apple. Several apple-shaped varieties mixed. Bottle. Fine, small; bottle-shaped. Very attractive. Hercules' Club. Grows 3 to 4 feet long: club-shaped. Egg-Shaped. White and striped varieties, mixed. Pear-Shaped. Striped green and yellow, mixed. Siphon, orDipper. Valuable for hou sehold purposes. Sugar Trough. Very large, with thick durable shell. Mock Orange. Closely resembles an orange.

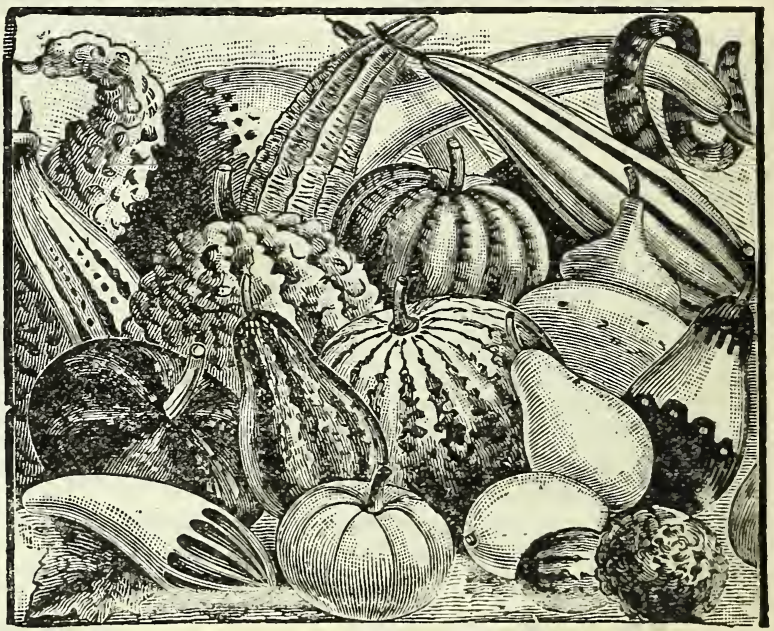

Any of the above, 5c. per pkt. The 10 varieties, one of each, 35c. All varieties mixed, 10c. per pkt.

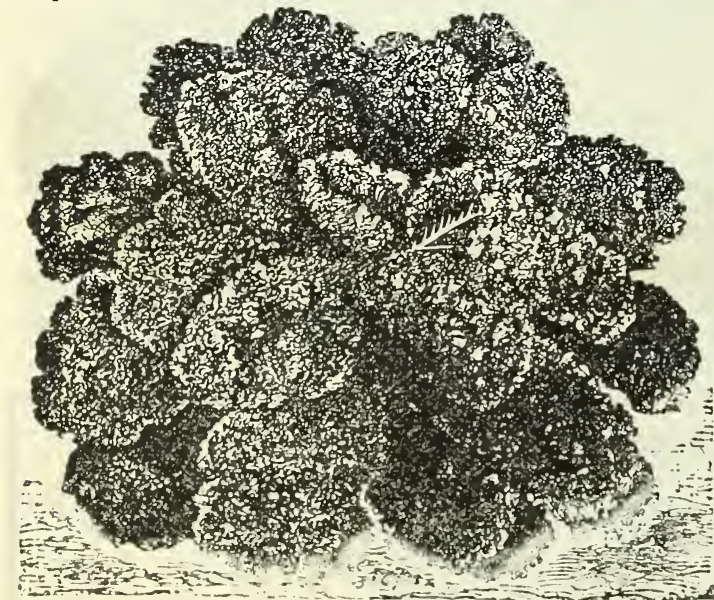

Kale, or Borecole.

A headless variety of Cabbage: very hardy and in some cases very handsome. Used for greens.

Green Curled Scotch. Grows twenty inches high and produces a luxuriant growth of dark green, curled and crinkled leaves. $1 / 4 \mathrm{oz}$. pkt 5 cts; $1 / 2 \mathrm{oz}, 10 \mathrm{cts} ; \mathrm{oz} .15 \mathrm{cts}$.

\section{Kohl Rabi.}

A vegetable of the Cabbage family, the stem being thick and globular just above the ground.

White Vienna. Early, dwarf. Bulb handsome, firm, glossy white; leaves few, small. Pkt. $5 \mathrm{c} ; 1 / 2 \mathrm{oz} .10 \mathrm{c}$; oz. 15c. Leek.

Broad Scotch or London. An Onion-like plant of mild flavor, highly prized for soups. This variety attains a large size; extremely hardy. Pkt. $5 \mathrm{c}$; $1 / 2 \mathrm{oz}, 10 \mathrm{c} ; 0 \mathrm{o} .15 \mathrm{c}$.

Gentlemen. "I have used your seeds for 20 years, and my mother did before me. I can positively a firm that during that period I hat'e had not one failure that could be attributed to the seeds. The "Golden Honey" Sweet Corn zuas the szveetest corn we ever ate. Thanking you for your fair dealings and wishing you success, I remain,

lours,

Mrs. C. S. P., St Croix Falls. Wis.

Cultural Directions. Many seedsmen tell sou that cultural directions will be found on each packet. Too limited to be of much value. Other seedsmen offer you leaflets, giving culture for some of the principle things. We give you FREE a 144-page book, "The Family Garden." It tells how to growall kinds of Fruits and Vegetables. It is sent free with every dollar order for seeds in packets and ounces, if you ask for it. 


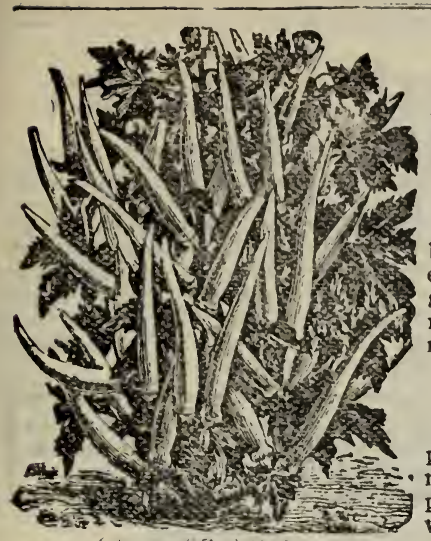

Giant Chinese Mustard.

A valuable varlety of Mustard that is very highly prized by many for salads or for boiling and serving like Spinach. The leaves are twice the sige of the ordinary Mustard. Can be used within six weeks after sowing. Pkt. 5c: oz, 10c; $1 / 41 \mathrm{lb} .25 \mathrm{c}$.

\section{Okra, or Gombo.}

White Velvet. This vegetable is highly esteemed in the South, and is rapidly becoming popular in the North and West. It is easily grown and greatly esteemed for stews, soups, etc. The young, tender seed pods are used similar to Asparagus or Snap Beans. The variety we offer is distinct in its appearance and manner of growth from the common varieties; the pods are much larger, thicker flesh, more tender and nutricious. One ounce sows 100 feet of $d$ rill. $5 \mathrm{c} ; 0 \mathrm{z}, 10 \mathrm{c} ; 1 / 4 \mathrm{lb} .20 \mathrm{c}$.

\section{Ornamental Pomegranate.}

An exceedingly interesting novelt $\mathrm{s}$, and also very ornamental. Grows on a very pretty vine; fruits orange yellow, slightly striped, and sometimes spotted red; varying from the size of a small peach to that of an orange. Very fragrant; sweetly perfuming the room with their exquisite odor for dass. Very prolific bearers, and OKRA, OR GOMBO

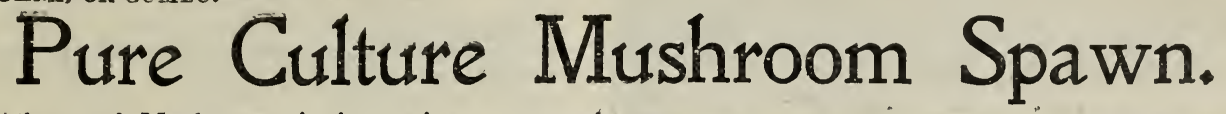

The culture of Mushrooms is increasing enormously. Their poptulatity is due to the ease with which they can be grown, in cellar, woodshed or barn. There is no secret process of growing: however, details are very important. The essentials to success are an even temperature of 50 to $60 \mathrm{de}-$ grees, and good fresh manure properiy prepafed.

Mushrooms used to be considered a luxury; but now all restaurants and hotels have them daily on their menus, and are very largely in demand for family use. Considering the first cash outlay and subsequent labor, they are the most profitable crop that can be grown.

We offer a very superior strain, known as "Pure Culture," produced by the new grafting process, from selected and most prolific varieties. It has always proven satisfactory. Price, ner brick, postpaid, 35 cents. By express, not prepaid, 25 cents each; 5 bricks for $\$ 1.00$.

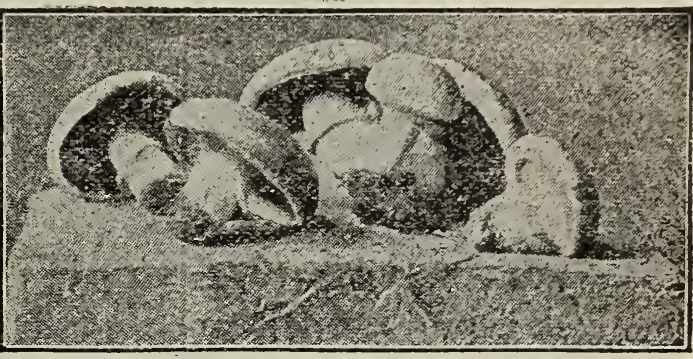

MUSHROOM CULTURE. We have, at considerable expense, published a neat 16-page illustrated booklet on growling Mushrooms. The most complete, up-to-date and reliable ever published. It tells you all you need to know to insire siccess. . Price, postpaid, to cents per copy. A copy will be sent free with every order for spawn.

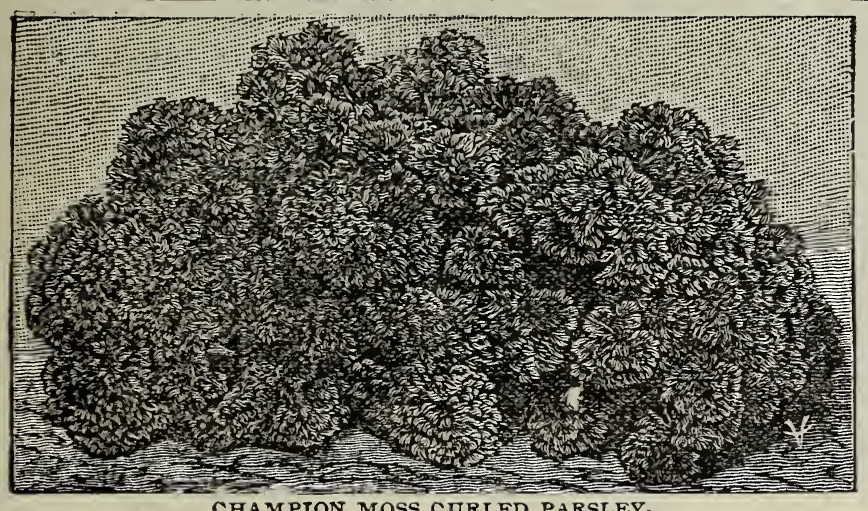

Rhubard, or Pie Plant.

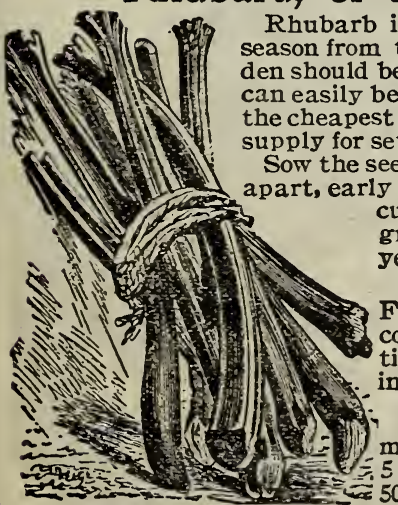

the first article of the cheapest possible way to secure a setting a permanent bed.

eds in drills 15 to 18 inches in the spring. Keep well cultivated and they will
grow quite large the first year.

Our 140-page book, "The Family Garden," gives complete cultural di rections for growing and forcing Rhubarb.

Linnaeus. This is the most popular variety. Pkt. $5 \mathrm{cts}$; oz. $15 \mathrm{cts}$; $1 / 4$ pound 50 cents: pound $\$ 1.75$.

\section{Parsley.}

Champion Moss Curled. A valuable English variety. The moss-like leaves are beautifully crimped and curled. Indispensable for seasoning soups, meats, etc. Useful for salads and garnishing. The lea ves, if dried in a cool place, will retain their flavor during the winter. Packet 5 cents; ounce 10 cents.

\section{Vine Peach.}

Fruit the size of a large peach, bright orange color. When it first ripens it is quite hard, but soon becomes mellow and sweet, and has a rich flavor. Flesh firm, with a small cavity in centre, and when peeled and the seed taken out they resemble peaches. Easily cultivated, wonderfully prolific, and can be used every way you would peaches. Pkt. $5 \mathrm{cts} ; \mathrm{oz} .20 \mathrm{cts}$.

Some splendid articles offered on first inside cover page. Nothing better in their classes. 


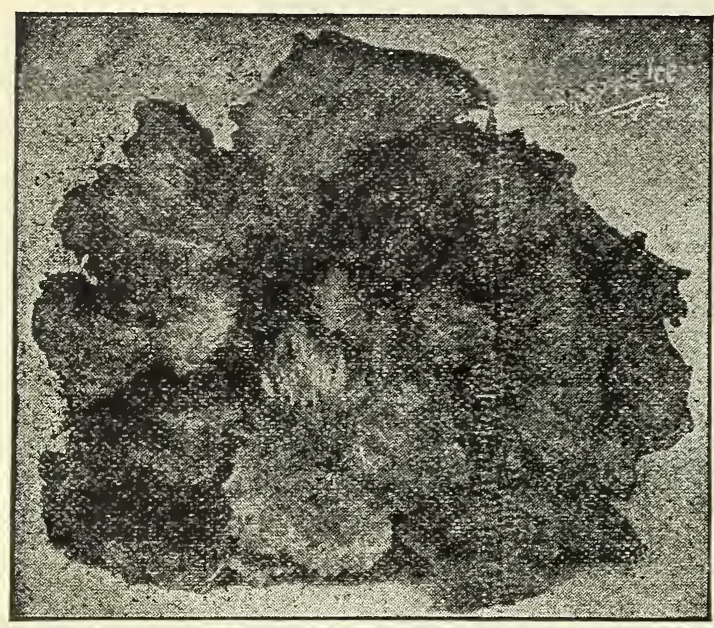

Crisp-as-Ice.

This is one of the most beautiful of the Cabbage type of Iettuce. The solid heads are of great size. The glossy leaves are thick and nicely crimped: outside they are variega ted with bronze and green. The heads, when cut open, have a rich creamy yellow heart. Crisp-as-Ice cannot be overestimated or overpraised. For home use during early spring and summer it is unexcelled. The leaves are so brittle and tender as to have suggested the name, "Crisp-as-Ice." Price, packet 5 cents; ounce 20 cents; $1 / 4$ pound 60 cents; pound $\$ 1.60$. By express, pound $\$ 1.50$.

\section{Choicest Lettuce.}

CULTURE-For very early spring use sow in hot-bed early in Maxch and transplant to the open ground soon as it can be worked. For later supply sow in the open ground during April and May, in rows 12 to 18 inches a part and thin out to 12 to 15 inches in the row. Do not cover more than one-fourth inch deep. By sowing at intervals of three to four weeks it may be had the entire season. One ounce will sow about 200 feet of drill. Our new book, "The Family Garden" gives quite complete instructions for growing all kinds of vegetables.

Each packet of Lettuce will contain one-sixth of an ounce. An ounce will produce about 2,500 plants.

Three pounds are required to plant an acre.

\section{"Unrivaled" Lettuce.}

This splendid Lettuce is an improved type of the popular Big l3oston, with smoother and more glossy leaves, Its outer leaves are entirely free from the faint brownish tinge noticable in the Big Boston when grown in the warm sunlight, while the heads are more solid, and they remain crisp and tender when most other varieties become tough and flabby under the hot sun. The Unrival ed is a splendid all-the-year-a round Lettuce; being excellent for cold frames or for cool greenhouses during the winter in the North or for the open ground in the South. It may also be planted in the open ground every two or three weeks from early spring until fall, and will produce crisp, solid heads throughout the season. We confidently recommend it to gardeners desiring a continuous supply of crisp. solid heads for the home table and for the critical market. Price, packet 5 cents; ounce 20 cents; $1 / 4$ pound 60 cents: pound $\$ 1.60$. By express, pound $\$ 1.50$.

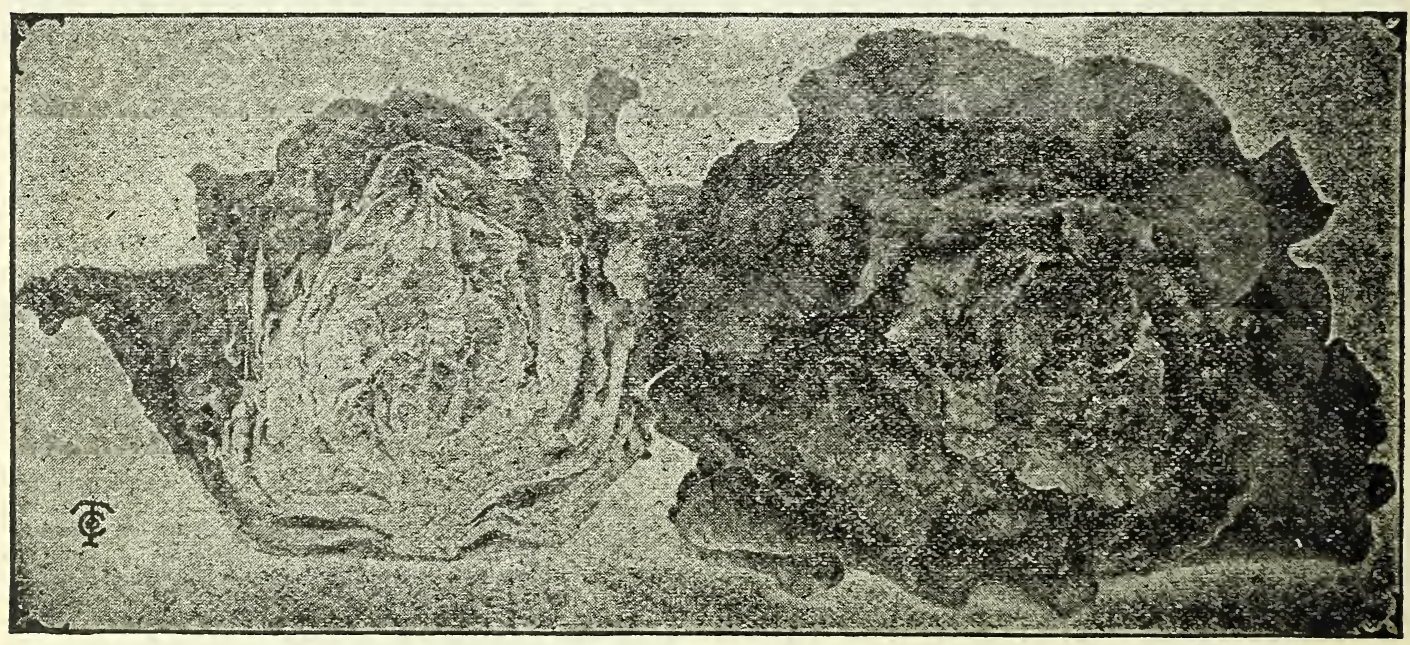

THE "UNRIVALED" LETTUCE.

\section{Improved Hanson.}

A grand old variety. None more reliable for outdoor cultivation. Heads grow to a remarkable size, resembling that of a flat Cabbage: so slow to run to seed that it often fails to form a seed stalk. The outer leaves are yellowish-green; inner leaves creamy white, deliciously tender, crisp and sweet, and free from bitter taste. It remains long in good table condition after reaching maturity. Particularly adapted to marlket gardening purposes. A perfect open air sort; very hardy: may be set out 7 in early spring. Pkt. $5 \mathrm{c} ; 0 z .15 \mathrm{c} ; 1 / 41 \mathrm{lb} .40 \mathrm{c} ; 1 \mathrm{~b} . \$ 1.25$. Ex. 1b. $\$ 1.15$.

\section{New York.}

A very popular Cabbage Lettuce, of unusual large size and solidity of head, with but little tendency to run to seed. Has been frequently grown eighteen inches in diameter and weighing three pounds or more with heads almost as solid as early Cabbage. Outside leaves are a distinct dark green, centre crisp, tender and of excellent flavor: always free from bitterness. It is not a forcing variety but is one of the best for summer use. Price, packet 5 cents; ounce 15 cents; $1 / 4$ pound 35 cents; pound $\$ 1.00$. By express, pound 90 cents.

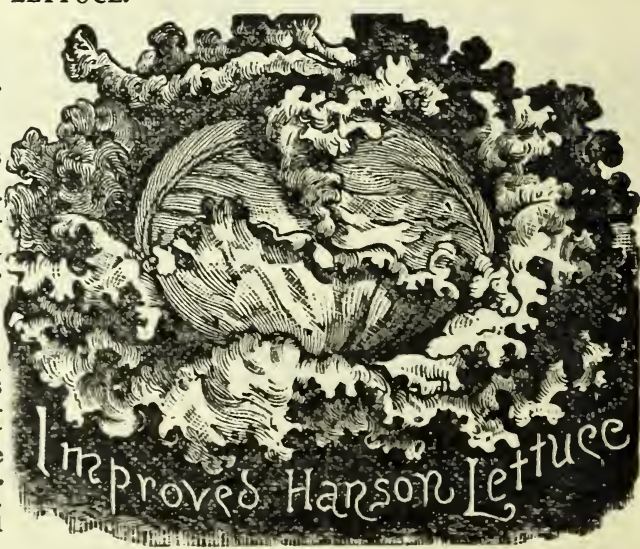




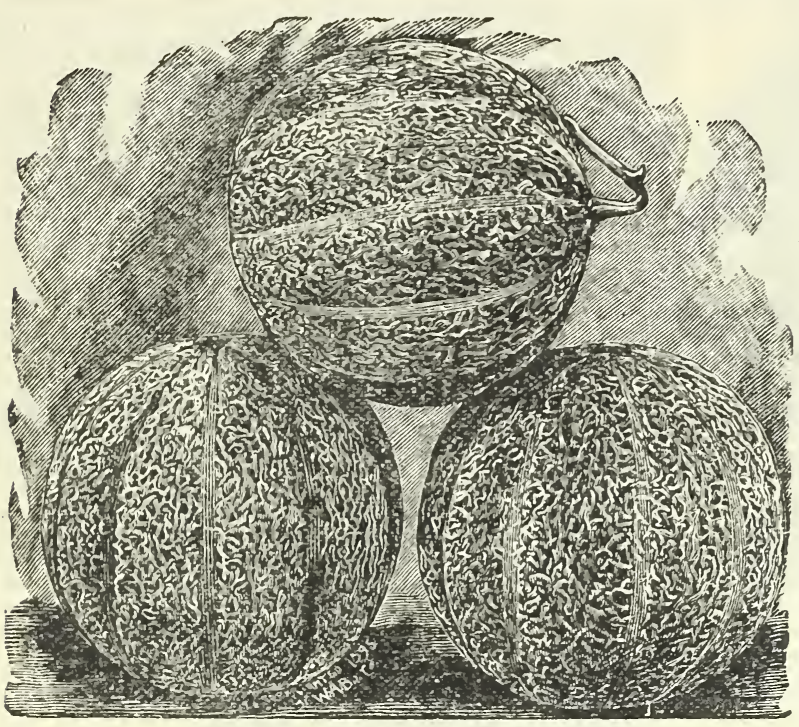

\section{Select Muskmelons.}

CULTURE.-Melons are rather exacting in their requirements. They need a warm soil, well supplied with thoroughly decayed vegetable matter or humus. This can be supplied by putting well rotted manure in the hills. Make the hills from 4 to 6 feet apart each way. After all danger of frost is past, plant the seeds one-fourth inch deep. For complete cultural directions, see our 140-page book, "The Family Garden." Price, 25 cents. We give it free with an order for Seeds in packets, amounting to $\$ 1.00$ or more. Ask for it.

Each packet of Muskmelons will contain 1-5 of an ounce; sufficient to plant 20 to 25 hills. Three pounds will plant an acre.

\section{True Rocky Ford.}

A splendid variety. Vines exceedingly healthy, bearing an enormous quantity of fruits. Groundcolor rich greenish gold; the netting is very prominent and is light in color. Flesh very deep, ripensmall seed cavity. Very sweet and luscious in flavor, and entirely free of any stringiness. The seed we offer are produced by a very reliable growcts; $1 / 4$ lb. $40 \mathrm{cts} ; 1 \mathrm{~b} . \$ 1.10$. By express, lb. $\$ 1.00$

\section{Miller's Cream.}

We consider this one of the best melons for home use, and also for the market, where it is known. While not a very early variety, the fruits will ripen perfectly in this latitude. It is a vigorous grower and very prolific, the whole crop being very even in size and shape. The fruits are extra heavy, owing to the thick meat and thin rind. The fruits grow to a large size, oblong in shape, dark green in color, with light netting. The flesh is a deep orange-salmon in color, ver $y^{n}$ thick, sweet, highly flavored and delicious. Throughout the season the melons a re of uniformly high quality, which cannot be said of many other varieties. We can heartily recommend Millers Cream to all who want a large melon of very high quality. Price, packet $5 \mathrm{cts}$; ounce $15 \mathrm{cts}$; $1 / 4$ pound $40 \mathrm{cts;}$ pound $\$ 1.25$, postpaid, BY express, pound $\$ 1.15$.

\section{Emerald Gem.}

This is truly a Gem, both in beauty and quality. The ribs are distinct, but the skin is smooth and a deep emeraldgreen color. The salmon-colored flesh is quite thick and firm, ripening almost to the rind, which is very thin. The flesh is very firm, and the flavor rich, sweet and luscious beyond description. The vines are thrifty, vigorous and very productive: the melons ripening extremely early. In productiveness and delicious flavor Emerald Gem is unsurpassed. Price per packet 5 cents; ounce 10 cents: $1 / 4$ pound 35 cents; pound $\$ 1.20$, postpaid. By express, not prepaid, pound $\$ 1.10$.

BURRELL'S GEM. This new variety is a decided improvement on the Rocky Ford. Experts pronounce it superior in
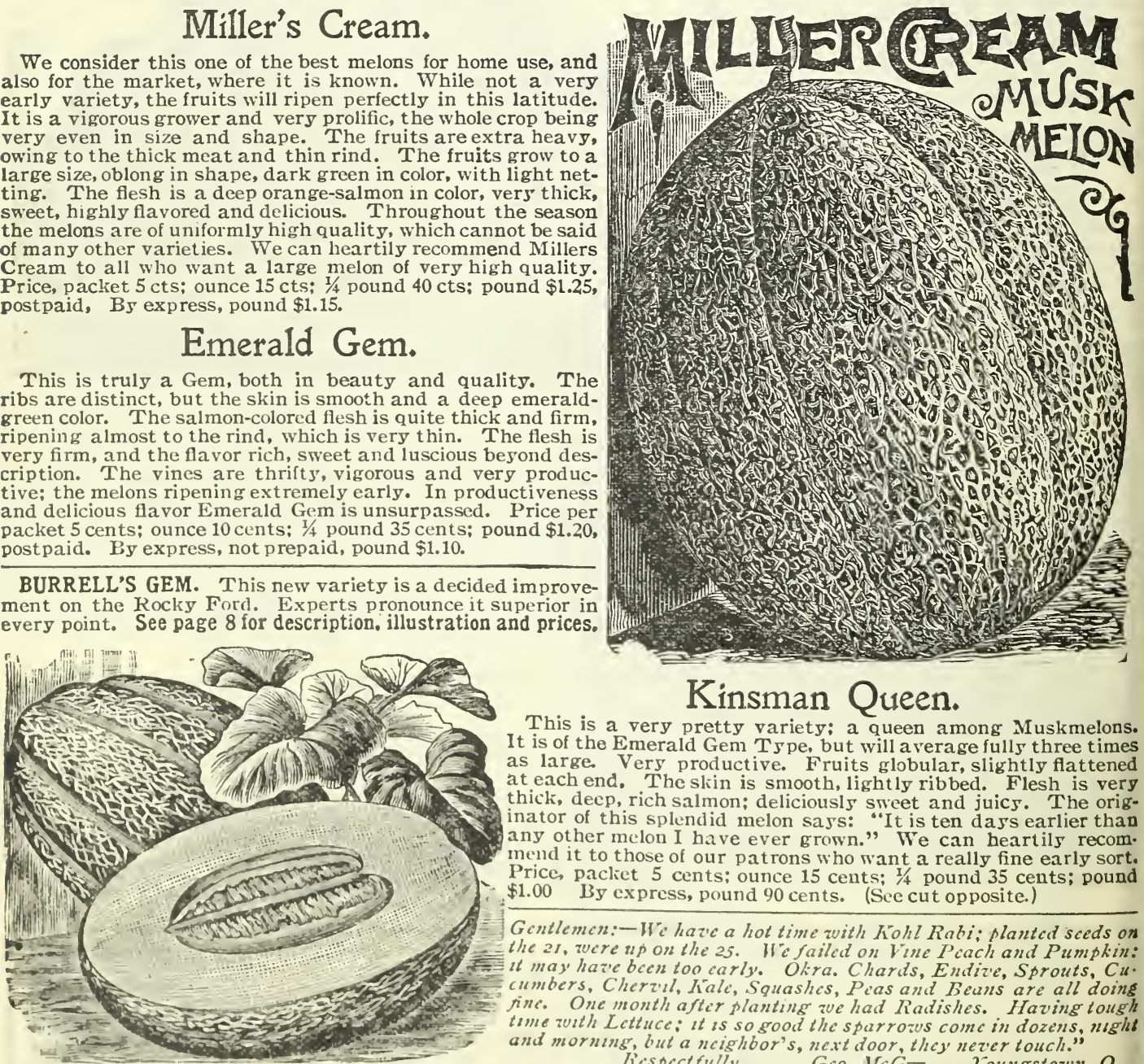

This is a very pretty variety; a queen among Muskmelons. It is of the Emerald Gem Trpe, but will a verage full 5 three times as large. Very productive. Fruits globular, slightly flattened at each end. The skin is smooth, lightly ribbed. Flesh is very thick, deep, rich salmon; deliciously sweet and juics. The originator of this splendid melon sass: "It is ten dass earlier than any other melon I have ever grown." We can heartils recom. mend it to those of our patrons who want a really fine early sort. Price, packet 5 cents; ounce 15 cents: $1 / 4$ pound 35 cents; pound $\$ 1.00$ By express, pound 90 cents. (See cut op posite.)

Gentlemen:-We have a hot time with folhl Rabi; planted sceds on the 21, zvere up on the 25. We failed on Vine Pcach and Pumpkin: "t may haze been too carly. Okra. Chards, Endize, Sprouts, Cu. cumbers, Cherizl, Lale, Squashes, Peas and Beans are all doing finc. One month after planting ave had Radishes. Having tough teme ruith Lettuce: it is so good the sparrows come in dozens, night and morning, but a ncighbor's, next door, thcy never touch."
liespectfully,
Gco. $\mathrm{ICC}$ -
Youngstown, $O$

OUALITY, NOT PRICE, The great importance of procuring GOOD SEEDS is generally not appreciated. The den is usually determined by the quality of the Seeds you buy. If the Strain is not gand profits obtained from the gareven on the best soil. We have alway considered that ONLY THE BEST IS GOODOod, a perfect crop cannot be grown 


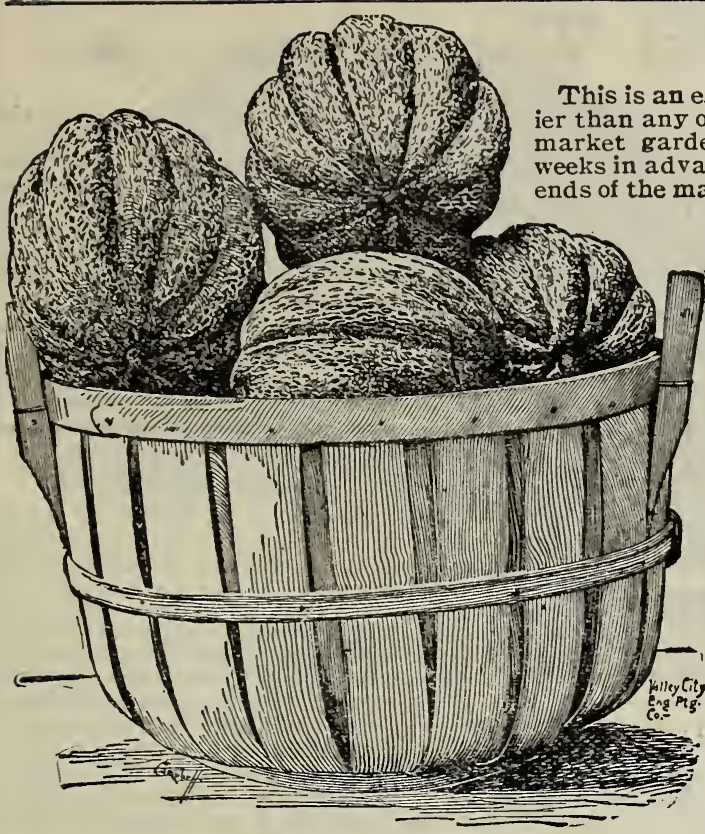

GRAND RAPIDS MUSEMELON.

\section{Grand Rapids Muskmelon.}

This is an extremely early Muskmelon. It matures fully a week earlgardener. Indeed, it is not infrequently in the market two vance of other varieties. We advise growers to pinch off the in shoots when two or three feet long, to encourage more abundant blooming and early maturity. The accompanying illustration shows the shape and comparative size. The flesh is yellow almost to the rind. The skin is finely netted, and the melons are very handsome in appearance, always attracting attention in the market. The vines are quite vigorous and productive; fruits uniform, large size and is a good shipper. The Grand Rapids is absolutely the earliest of the large melons, and we particularly recommend it to those of our patrons who want to be first in market. Pkt. $10 \mathrm{cts}$; ounce $15 \mathrm{cts} ; 1 / 4$ pound 35 cts; pound $\$ 1.10$. By express. pound $\$ 1.00$.

\section{Perfection IVIuskmelon.}

This is a superb variety of recent introduction. In shape they closely resemble the famous Rocky Ford, but the fruits are considerable larger; they frequently attain a weight of 8 to 10 pounds. Vines are quite vigorous and healthy. Color of the skin is dark green, quite heavily netted; fruits distinctly ribbed. Flesh rich orange. The originator says, "I challenge any seedsman in America to produce a finer melon in fla vor and general a ppearance." The melon is nearly all flesh, the seed cavity being small, hardly large enough to accommodate the seed. It is really so thick fleshed and so large that one melon is enough for four people under ordinary circumstances. Adapted to home use or for market. Pkt. 5 cts; ounce $15 \mathrm{cts}$; $1 / 4$ pound $40 \mathrm{cts}$; pound $\$ 1.25$. By express, pound $\$ 1.15$.

Early Hackensack.

A very bountiful yielder, and one of the most extensively grown of all Muskmelons. By some dealers it is called Turk's Cap. It is a valuable variety for market, being fully ten days earlier than the well known old Hackensack which it resembles in size, shape and quality. The fruits are large, weighing five to ten pounds each: round, slightly flattened at each end, and well ribbed; the skin is deeply netted. The flesh is green, tinged yellow toward the centre, and of most sweet and delicious fla vor. The vine is a very strong grower, producing five to seven good melons on each riue. Because of its earliness, Early Hackensack has become very popular with market gardeners everywhere. For many years a great favorite in New York market, being a good shipper. Pkt. 5 cts: ounce $10 \mathrm{cts}$; $1 / 4$ pound $35 \mathrm{cts}$; pound $\$ 1$. By express, pound $90 \mathrm{cts}$.

Gentlemen: "In point of quantity, quality, purity, certainty to grow and productiveness, your Seeds are superior to any within my knowledge. Please send three catalogices; one for myself and two for my neighbors, who are flower lovers and gardeners, and are not satisfied with the high prices they pay for seedselsewhere." Tours truly,

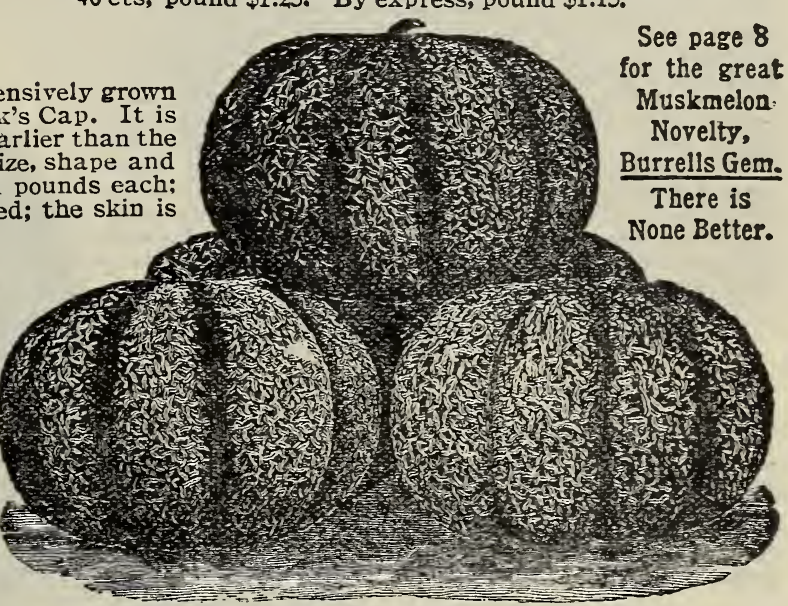

EARIY HACKENSACK MUSKMELON.

\section{A Valuable Book, "The Family Garden."}

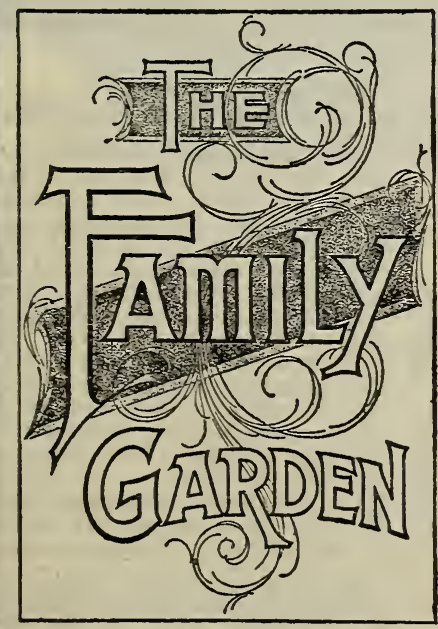

This is the most concise, practical and valuable treatise on Gardening ever published for the price. It will tell rou just what you need to know to insure your success with all kinds of Vegetables, Flowers and Small Fruits. You will find it indispensable as a book of ready reference.

\section{TABLE OF CONTENTS.}

Following are part of the subjects treated: Location of Garden. Manures, Preparation of Soil. Seeds.-buring testing, sowing. How plants growifrom Seed. Plants and Transplanting. Verieties and their Development. How to kill Weeds. Cultivation. Cultural direction for Vegetables. Miscellaneous Seeds. Medicinal Plants. The Flower Garden. The Fruit Garden. Fungicides and Insecticides. Also many other subjects under these general headings. Monthly Calendar. Tables of weight of seeds, quantity per acre, a verage germination of Vegetable and Flower Seeds, longevity, etc.

Price, 144 pages, handsomely embossed cover, 25 cents each.

Gentlemen:- "I wish to say a word about your book, "The Family Garden." My nephew sent me a copy some two years ago and I think it valuable. I was compelled to quit factory work through ill health, and I took up market gar. dening on a small scale. The book has been my standard for reference. It has always proven reliable. Ed. Wakeham, Sewickley, Pa.

\section{HOW TO GET THE BOOK FREE.}

A copy of "The Family Garden" will be sent FREE with every order for Seeds emounting to $\$ 1.00$ or more, if you state in your order that you want it. 


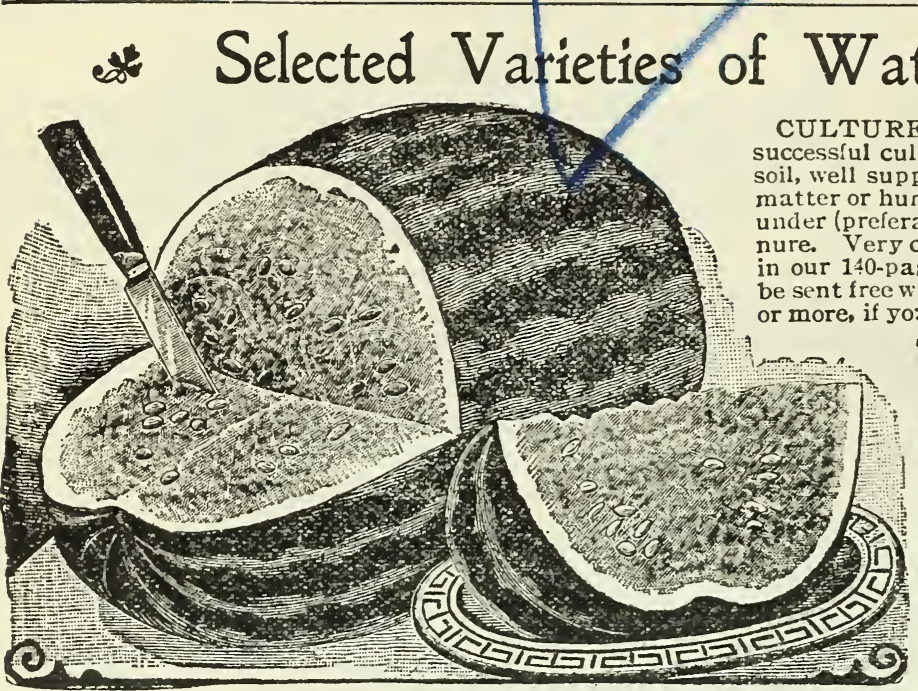

NEW HARRIS EARLY WATERMELON.

\section{Black Diamond.}

A cross between Kolb's Gem and Hoosier King. All that can be said of Kolb's Gem as to its shipping qualities can be truthfully stated, in a higher degree, of Black DiaSweet Heart, can be repeated for this splendid melon. Its most prominent point of merit is its extreme size; no other variety produces anything like so uniformly large fruits, or equals it in productiveness. They frequently weigh from 70 to 80 pounds. Its color is a rich, dark green, almost black. Of uniform symmetrical shape, roundish to bluntly oval, the similarity of shape running through the entire crop. In habit the vines are extremely vigorous and healthy. Valuable for both the home and market gardener. Packet $5 \mathrm{cts}$; lounce $10 \mathrm{ct}$. $1 / 4$ lb. $25 \mathrm{cts}$; lb. $85 \mathrm{cts}$. By express, pound $75 \mathrm{cts}$ wisect

\section{The Dixie.}

In this we have a variety of exceptional merits, and we can recommend it as the best shipping melon grown. It is earlier, larger and far more productive than Kolb's Gem, which was hitherto considered the best shipper; and is darker green, more beautifully striped, longer and vines hardier. Flesh sweet, juicy and tender. It is very productive, having 6 to 8 large melons on a vine.

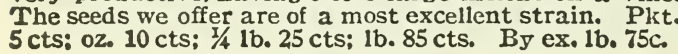

\section{Hungarian Honey.}

This superb melon comes from Hungary, and is un questionably one of the sweetest and most luscious varieties grown. Of medium size, perfectly round, and dark green in color. Flesh brilliant red; seeds small and distinct, Very uniform in size, a veraging 10 to 12 pounds. Pkt. 5 cts; 0z. 15 cts; $1 / 4$ lb. 35 cts; 1 b. 90 cts. Ex. 1b. 80 c.

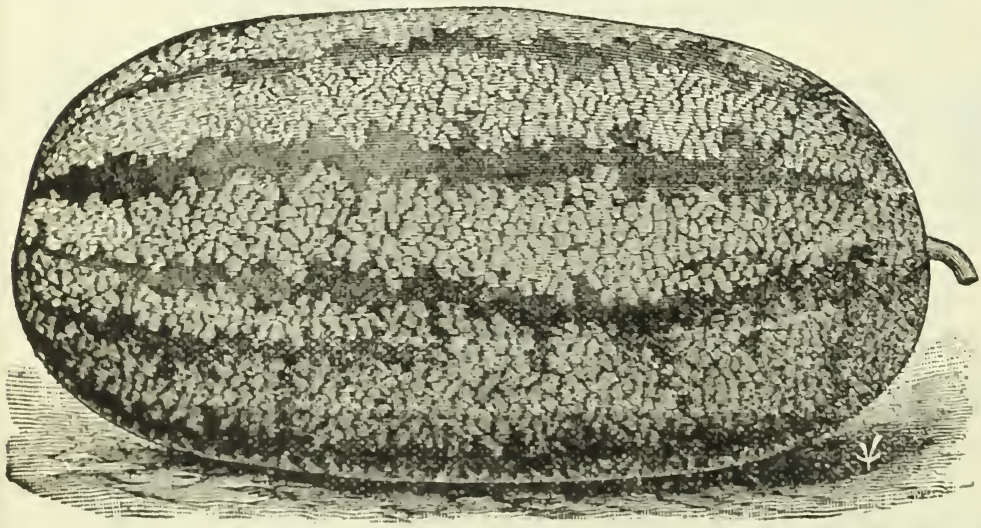

THE WONDERFUL SUGAR WATERMELON. we ever had the pleasure of eating. The
form and general appearance is well represented by the illustration. The Tennessee Experiment Station reported it as the earliest variety on their trial 65 days from planting. Every gardener should give it a trial. Pkt. 5 cents; oz. 15 cents; $1 / 4$ lb. 35 cents; lb. \$1.10. By express, pound $\$ 1.00$.

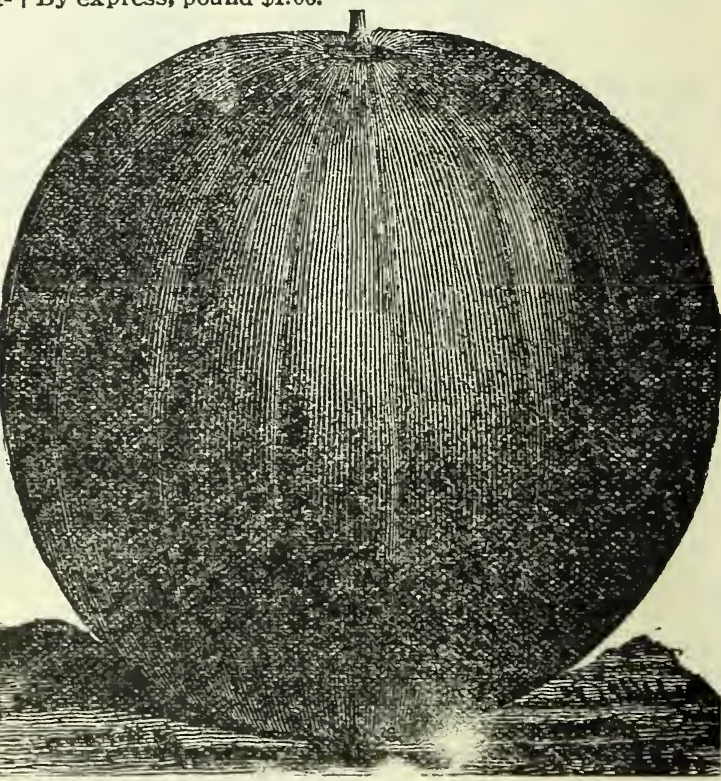

BLACK DIAMOND.

\section{Wonderful Sugar.}

This fine varicty originally came from the West Indes, and is famous for its high quality. It is noted for beauty and lusciousness, being exceedingly sweet and juicy. It is of medium size, skin striped and variegated. Flesh rosy pink, perfectly solid, free from stringiness: sweet and delicious in flavor, and of fine texture. The vines are very thrifty and strong: very prolific. and well adapted to withstand wet weather or drought. It is of great value for the home or nearby $\mathrm{mar}$ liets, the rind being rather too tender to withstand long freight shipments. Plit. 5 cts: $10 z, 10 \mathrm{cts}: 1 / 4 \mathrm{lb}$ $30 \mathrm{cts}$ : $1 \mathrm{~b} .90 \mathrm{cts}$. Express, $1 \mathrm{~b} .80 \mathrm{c}$.

HALBERT'S HONEY. This grand new Melon will be found lllustrated and described 00 page 8. 


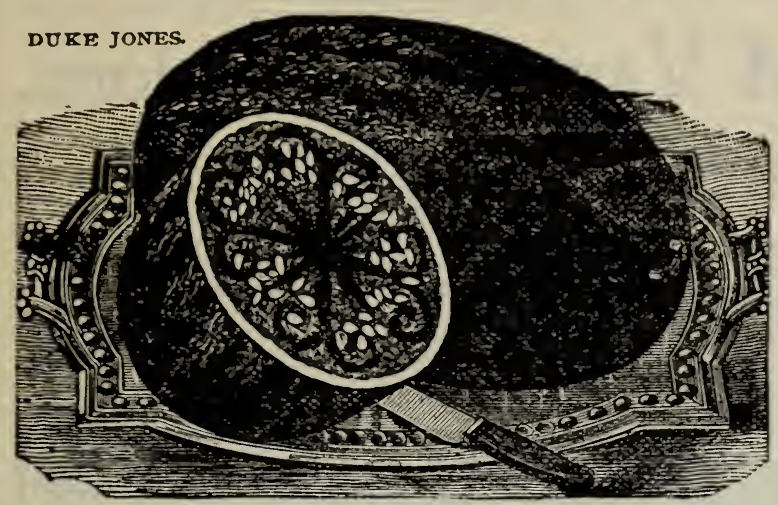

\section{Duke Jones.}

One of the largest and most productive melons. Oval in form; color, dark green, slightly mottled. Flesh bright red, very sweet and juicy, and an excellent shipper. The melons a verage very large, occasionally weikhing 60 to 70 pounds. Here is what a $R$. R. man says of it: "Mr. Girardeau has shipped ten car loads of the Duke Jones melons over our road. The cars all averaged 40 pounds to the melon: one car a veraged 43 pounds each. They were the finest lot of melons I ever saw, and the quality was delicious." Packet $5 \mathrm{cts}$; ounce 10 cents; $1 / 4$ pound $25 \mathrm{cts}$; pound 75 cents. By express, pound 65 cents.

\section{Kolb's Gem.}

This is a favorite among Southern growers for ship. ping purposes. The shape is oblong to nearly round; color, dark green with light green markings. The Cole's Early.

This is considered the finest Watermeion for family use and the market. The melons are not large-seldom over 12 inches long and 8 inches in diameter; but what they lack in size they more than make up in number, solidity and excellency of flavor. The flesh is beautiful bright red, crisp, and of the most delicate texture, juicy and sparkling. In flavor it is lusciously sweet and refreshing. It is very solid; there is little cavity and few seeds-all solid flesh, there being a very thin rind. They are alr ost round in shape, mottled with various shades of green. It is very early, and can be grown successfully over a larger latitude than any other variety. It will mature large crops in the northern states. It is not only the earliest in cultivation, but it continues to bear throughout the season. Pkt. 5 cents; ounce 10 cents; $1 / 4$ pound 20 cents; pound 70 cents. By express, pound 60 cents.

\section{Sweet Heart.}

For home and market use it will hold its own in popularity for many years to come. Car loads still sell at fancy prices in the large markets, and its quality is A 1 . Following is an accurate description: Vines vigorous and productive, ripening its fruit early. Fruit large, oval, very heavy, uniformly mottled light and dark green; rind thin but firm: flesh bright red, solid but very tender, melting and sweet. Remains in condition for use longer than any other sort. Include this variety in

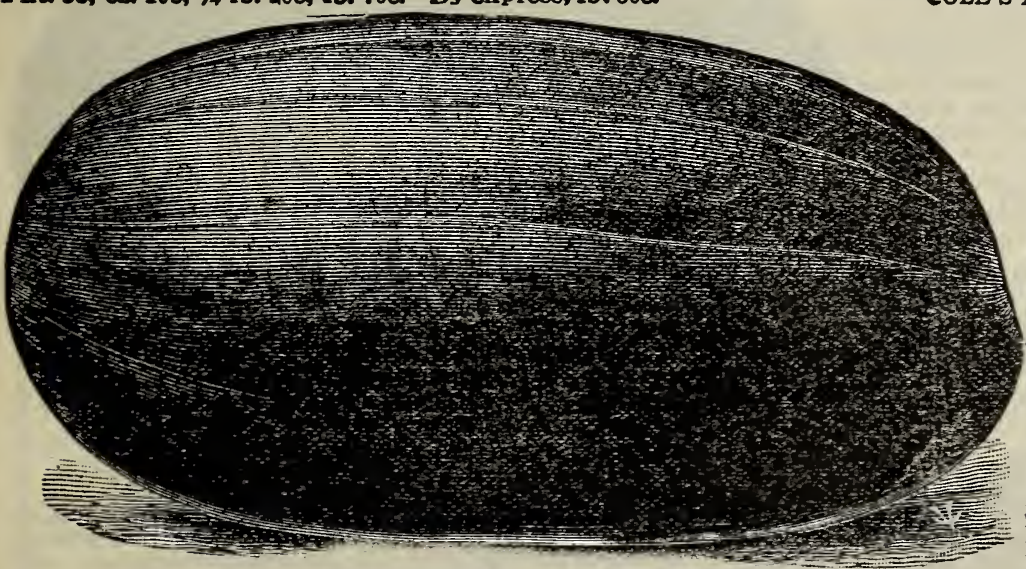

KLECKLY SWEET WATERMELON. melons weigh from 30 to 50 pounds each. The rind, though thin, is tough and the melons bear handling and quality. The vines are productive, and it is considered profitable market melon. Pkt. 5 cts; ounce $10 \mathrm{cts} ; 1 / 4$ nd $25 \mathrm{cts}$; pound $75 \mathrm{cts}$. By express, pound $65 \mathrm{cts}$.

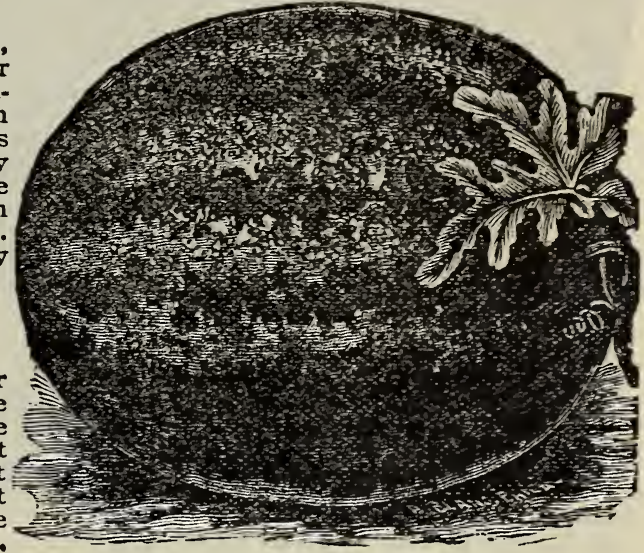

COLE'S EARLY WATERMELON.

\section{Kleckly Sweet.}

Large, oblong melon 20 inches in length by 10 to 12 inches in diameter: somewhat tapering at the ends. Dark green; flesh is bright scarlet, ripening close to the rind. Seeds white, lying close to the rind, leaving a large solid heart that does not crack open when ripe. Sweet and sugary anc is of such texture that it leaves no strings or pulp whatever in eating. The only drawback to this melon is that it is too tender to stand shipping. Pkt. ic: oz. 15c; $1 / 4$ lb. 30c; 1b. $\$ 1$. By exगress, lb. $90 \mathrm{cts}$.

COLURADO CITRON. Makes almost transparent preserves. Superior to the ordinary Citron. Immensely productive. Will kee? the entire winter. Pkt. 5 cts; oz. $10 \mathrm{cts} ; 1 / 4 \mathrm{lb} .25 \mathrm{cts}$.

\section{\begin{tabular}{c|c|c|}
255 & Our Popular Family Collection \\
\hline crTs \\
crs
\end{tabular}}

For many years we have been offering this extraordinary collection of Garden Seeds. Each year we sell thousands of them, with the demand steadily increasing. We have never yet heard of a patron who was not satisfied with the quantity and quality of the seeds.

It is the Largest and Most Complete 50 Cent Collection Ever Offered.

Our patrons are always both surprised and delighted when they receive this collection. "Never received so many seeds for my money." "How can you sell seed so cheap?" "Can't find room to plant them all," and mans similar expressions are common. They are all Positively First-class, Strictly Fresh, Tested Seeds.

Don't for a moment think the seeds in this collection not good: they are strictly fresh. Our object in making this extraordinary offer is to ind uce you and your oriends to plant our "Ideal" seeds.

See page 54 for description of the collection. Tell your friends about it. 


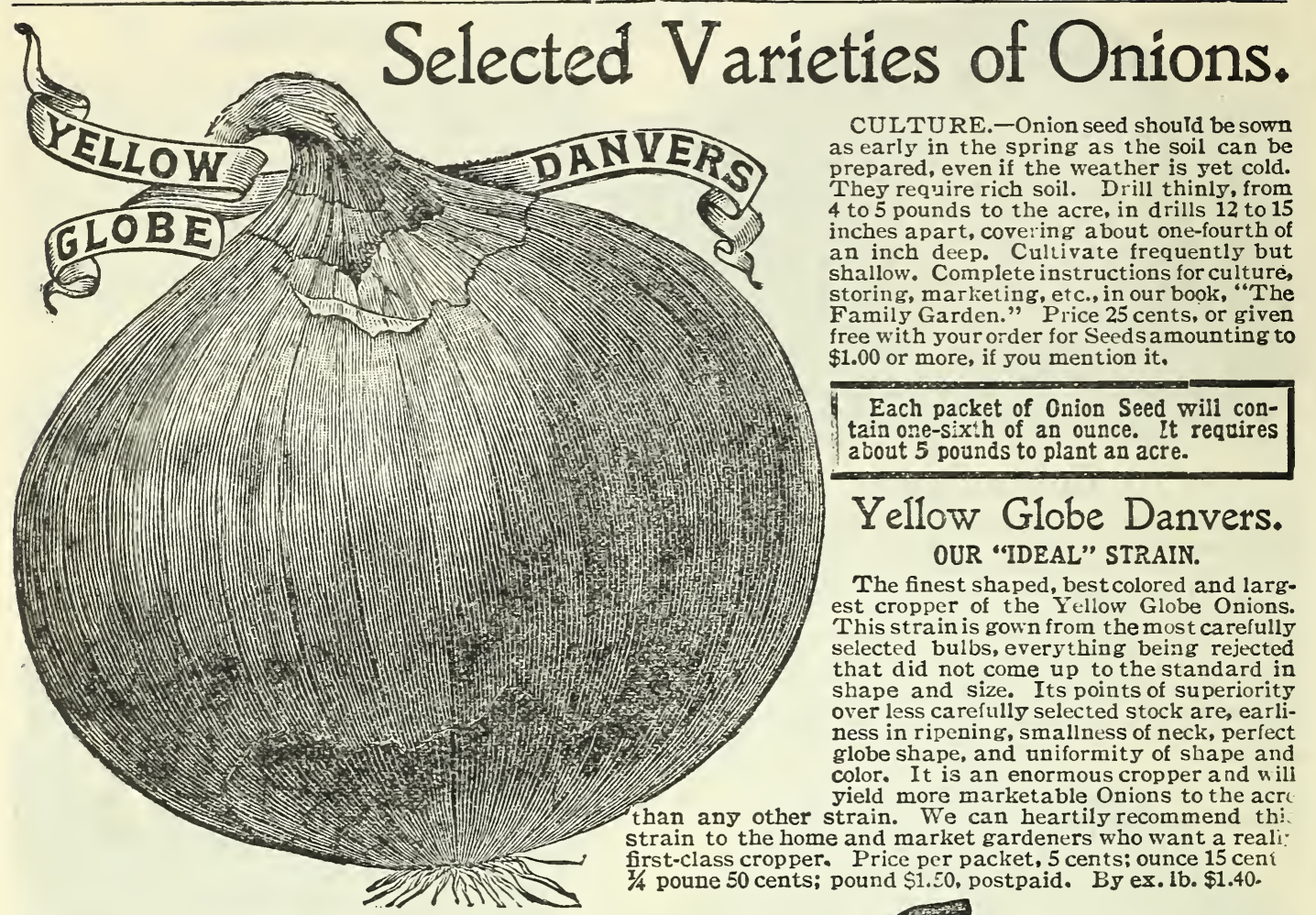

\section{Large Red Weathersfield.}

It is often onl 5 a matter of color in growing Onions. To those who prefer a red variety we can heartily recommend the Red Weathers. field. Next to Giobe Danvers, this variety is most largely grown. It yiclds fully equal to the Danvers; in fact many growers claim it to be even more productive. Large size, purplish red skin; flesh white, fine grained; in shape round, slightly flattened on the top. Its splendid keeping qualities make it easy to hold the crop for winter when prices are high. Packet $5 \mathrm{cts}$; ounce $15 \mathrm{cts}$; $1 / 4$ pound $40 \mathrm{cts}$; pound $\$ 1.25$ By express, pound $\$ 1.15$.

\section{White Portugal.}

Also known as "Silverskin." A splendid variety, noted for its mild and pleasant flavor. Skin silvery white; of handsome appearance; medium in size. A fine market Onion, and also prized by many for pickling. Extensively grown for white sets. Ripens early, a prolific bearer and excellent keeper. Pkt. 5 cents; $0 z$. $15 \mathrm{cts} ; 1 / 4$ 1b. $50 \mathrm{cts} ; 1 \mathrm{~b}$. $\$ 1.75$. By ex. $1 \mathrm{~b} . \$ 1.65$.

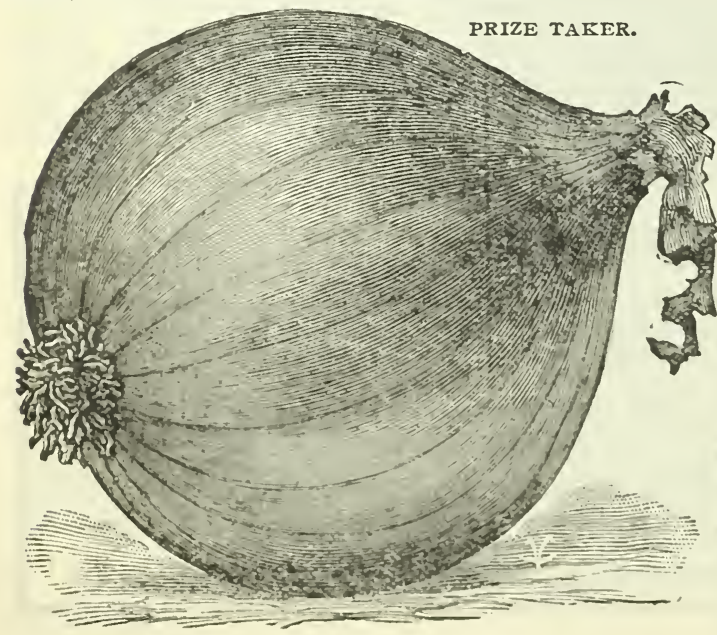

IARGE RED

WEATHERSFIED.

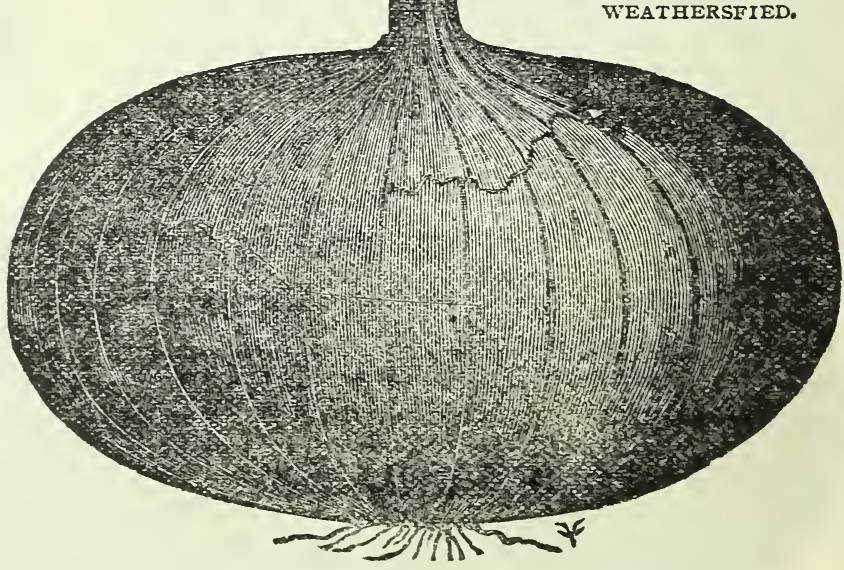

Mammoth Prize Taker.

This magnificent Yellow Onion has steadily increased in popularity since its introduction in 18s8. It is ret considered, by many growers the largest, handsomest, finest tlavored, most productive and profitable Onion now in cultivation. It closely resembles the beautiful large Spanish Onion we see offered in our city markets at very fancy prices. In fact the only difference between them is that the Prizetaker is grown in A merica from American grown secd, while the others are imported. Thes are of a clear bright straw color, and always grow to a uniform shape, being a perfect globe with a very small neck, and always ripening up perfectly. Of uniform large size, frequently weighing two to three pounds each. The seeds we offer are American grown, being far superior to imported seed. Paclict $5 \mathrm{cts}$; ounce $15 \mathrm{cts}$; $1 / 4$ ponnd $50 \mathrm{cts}$; pound $\$ 1.75$. By express, pound $\$ 1.65$.

CRDER ONIOMS EARLY, It will be greatly to your ERRY, advantage to order your Onion sered early. The advantage will be in that you will have the seed read $y^{r}$ to plant when the ground fs in condition. It will also give a chance to test them, though this is not necessary, as our seed are all fresh 


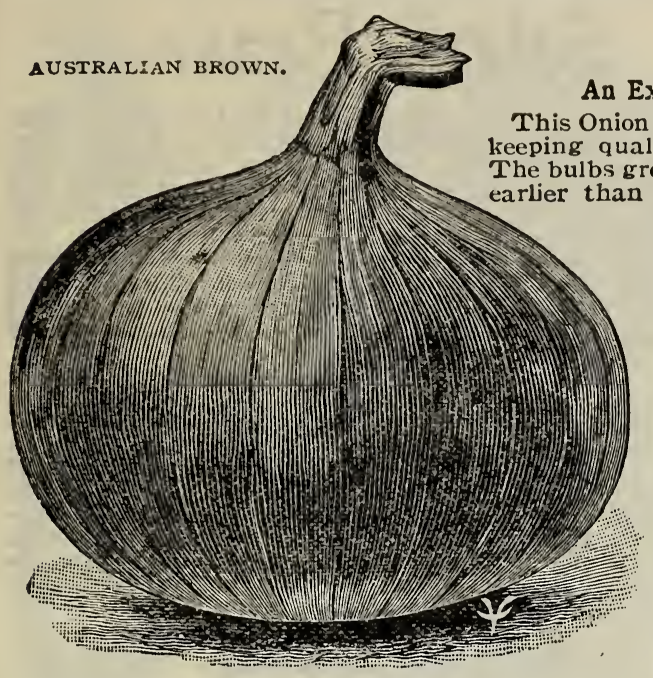

\section{Australian Brown Onion.}

An Extra Early, Long Keeper. A Great Favorite Everywhere.

is Onion is of comparative recently introduction, and its extraordinary The bulbs grow to a good marketable size and are very solid. They ripen either Yellow Danvers or Red Weathersfield, are a beautiful brown color and of mild flavor. A good thing in its favor is the fact that the crop runs quite uniform in size and sirape: nearly every plant produces a fine Onion. It has the reputation of keeping almost indefinitely. From its firmness we believe it will keep in good condition longer than any other variety. When once bought in the marliet, the parchaser invariably returns and asks for "those beautiful brown Onions." Packet 5 cts; oz. 25 cts; $1 / 4$ lb. 60 cts; 1 b. $\$ 1.90$. By express, 1 b. $\$ 1.80$.

\section{Extra Early Red.}

This is a standard extra early variety that matures 10 days earlier than Red Weathorsfield, and on rich soil grows almost as large. It will succeed in cold, mucky soil where many other sorts would fail. It can be made to produce fine, marketable Onions in 90 days from the sowing of seed. Color, deep, r:ch red; fine grained, solid and heavy. It is mild in flavor and will keep quite well. Extra Early Red will succeed almost anywhere, but is peculiarly fitted for northern latitudes, where the seasons are sborth Pkt. 5c; 0z. 20c; 1/4 1b. 60c; 1b. \$2.00.

\section{New White Queen.}

This is a very distinct variety on account of its earliness. The shin is a beautiful waxy white, and are generally rather small, about $1 \frac{1 / 4}{4}$ inches in diameter and $3 / 4$ of an inch thick: alwass producing finely formed bulbs, slightly flattened at the top. They are extremely early, quite productive, and are largely used for early bunching and pickling. Its extreme earliness will highly recommend its use as a substitute for onion sets. Should be thoroughly dried and stored in a dry place as snon as matured. Pkt. 5c; oz. 25c; 1/4lb. 60c; 1b. $\$ 2.00$. By ex. 1b. $\$ 1.90$.

\section{Early Bermuda.}

An extra early Onion. It is profitably grown in the South for early northern markets. Skin is light straw; flavor mild. Will grow well in our climate but not quite so large. Packet $5 \mathrm{cts;}$ oz. 20 cts; $1 / 4$ 1b. 60 cts; 1b. $\$ 1.90$. Ex. 1b. $\$ 1.80$.

\section{Extra Early Barletta.}

The earliest Onion in cultivation. They are pure white, very mild and delicate in fla vor. Size, from 1 to $1 \frac{1}{2}$ inches in diameter. At maturity the tops die down directly to the bulbs, leaving the nea test and handsomest little Onions imaginable. Unsurpassed for pickling. Plt. $5 \mathrm{cts}$; ounce $25 \mathrm{cts} ; 1 / 4$ lb. $60 \mathrm{cts} ; 1 \mathrm{~b}$. $\$ 2.00$. By ex. $1 \mathrm{~b}$. $\$ 1.90$.

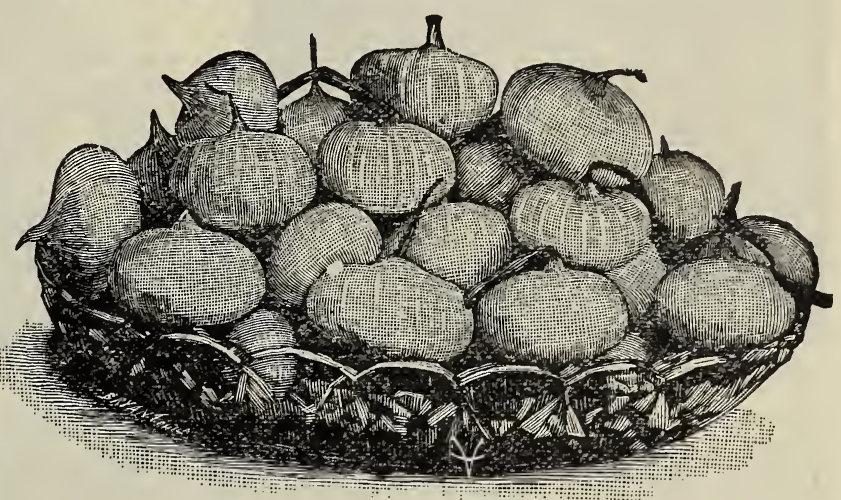

NEW WHITE QUEEN,

\section{Mammoth Silver King.}

One of the largest and most attractive varieties in cultivation. Specimens are frequently grown to weigh from 2 to $2 \frac{1}{2}$ pounds. Very handsome in appearance, silvery white in color. Excels all others in mildness and sweetness of flavor. Always command the highest price. Pkt. 5 cts; oz. 25 cts; $1 / 4$ lb. 75 cts; 1b. $\$ 2.25$. By ex. 1b. $\$ 2.15$.

\section{SOUTHPORT GLOBE ONIONS.}

During the last four or five years there has been a wonderful increase in the popularity of the Southport Globe Onions. In almost all markets they will invariably bring top prices. They are not only more handsome in appearance, remarkable solidity and good keeper, but also fully equal in yield to any of the strains of other varieties. They are strictly eastern-grown; and it is an acknowledged fact that they are superior to the western-grown, in that they make a harder, better keeping Onion. The western growers have to come. East for their bulbs on account of this characteristic. The seed we offer are from carefully selected bulbs of the round globe variety. They will satisfy.

\section{SEE PAGE 8 FOR ILLUSTRATION, DESCRIPTION AND PRICES.}

So

Frices by the bushel vary with the market. Please write for quotations.

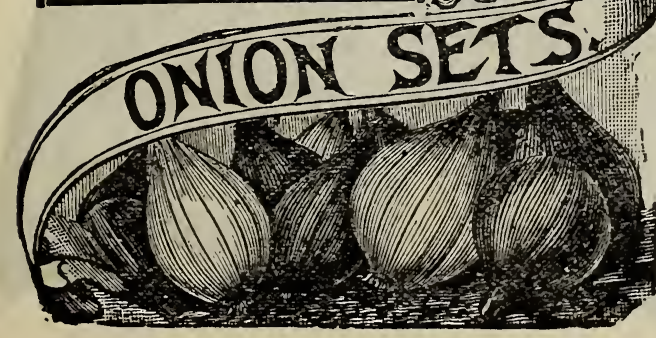

There has been a rapidly increasing demand for Onion Sets during recent years. By their use onions may be had for table use muchearlier in the spring than when grown from seed, and they are also less trouble to grow. The sets we offer are grown in a section adapted to their growth; they are hard and sound, and carefully hand cleaned by us.

The price of Onion Sets by the bushel fluctuate so much, owing to the short or abundant crop, that we do not quote prices thereon in this catalogue. Prices sent on application.

Yellow. These are grown from Yellow Danvers and Strasburg seed, and will produce Onions of good size and quality. Price, postpaid, quart 35 cents. By express, not prepaid, quart 25 cents; peck $\$ 1.25$.

White. Grown from a fine strain of White Silverskin. Fine for early bunch Onions, or if allowed to mature will produce fine large Onions. Price, postpaid, quart 40 cents. By express, not prepaid, quart 30 cents; peck $\$ 1.35$. 


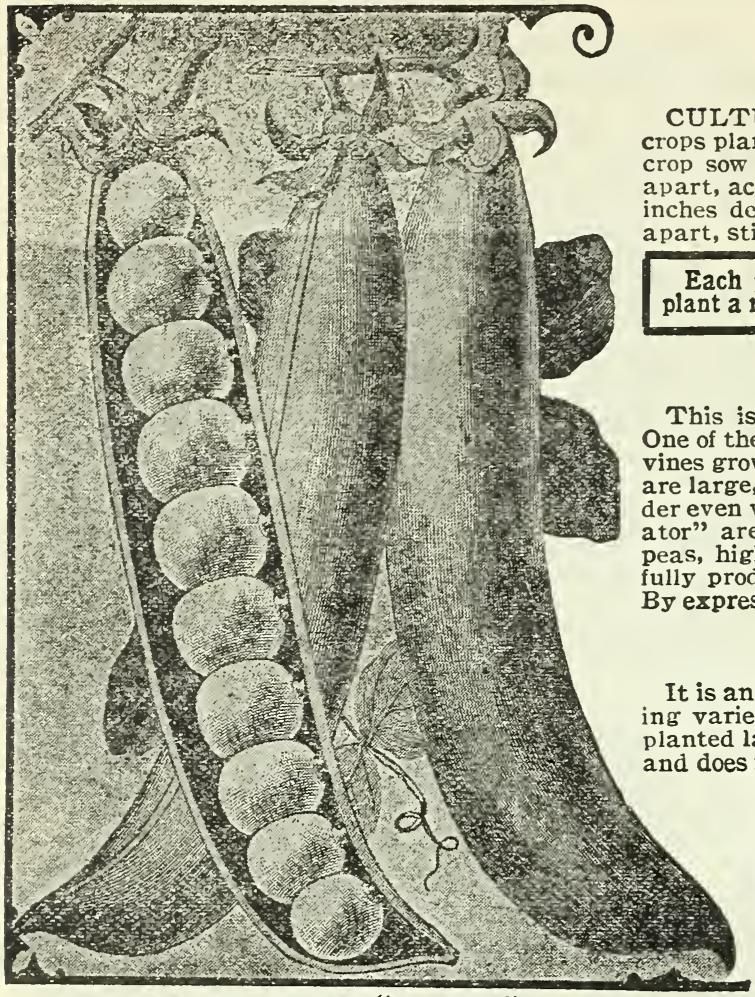

Premium Gem.

A very fine, extra early dwarf Pea of the Little Gem type, on which it is a decided improvement; larger pods and more productive Only about three days later than American Wonder. Vines grow only 12 to 15 inches high; pods $2^{1 / 2}$ to 3 inches long, round, well filled with peas of most delicious flavor. Bxcellent for both family and market gardeners; they need no brush. Packet 5 cents; pint 25 cents; quart 45 cents. By express, quart 35 cts; peck $\$ 1.85$.

\section{The Gradus Pea.}

This grand variety is the earliest wrinkled or marrow Pea grown year has added to the popularity of this splendid variety until it has become a leader. The distinctive points of merit are extreme earliness, remarkable productiveness, large size and excellent quality. A very hard $y$, vigorous grower, about $2^{1 / 2}$ feet high, heavy stemmed, with luxuriant foliage. Can be planted as early as the early smooth sorts. Produces in great abundance its very large pods, with from 6 to 10 true, large wrinkled peas or dellcious flavor; as large, sweet and tender as the finest late wrinkled varieties; pods uniformly handsome, and although bearing very early it continues for a long time. Color, beautiful light green, which they retain when served. The sweetest, most tender and delicious peas grown. Market gardeners recognize this as one of the most profitable varieties. (See cut opposite.) Packet 5 cts; pint 35 cts; quart 60 cts. By express, quart 50 cents; peck $\$ 2.50$.

\section{Long Island Mammoth.}

This is a very large, mid-season variety of exceptionTherit for market gardeners on account of the large size, remarkable productiveness, and the fine appearance of its well filled pods. The flavor is all that could be desired, being tender, sweet and luscious. The pods are glossy green and very attractive. The peas are almest smooth when dry. In vine it is a strong, luxuriant grower, hardier and larger than Telephone and with darker foliage. Grows about three feet high.

Gardeners will find this a great favorite, as picking is easy and they present a very handsome appearance to the eye of the buser. It reaches the market after the early sorts are gone, and is sure to sell on its beauty and high quality. It is a profitable Pea for both the and high quality. Garden, and is a great favorite wherever known. Packet 5 cents: pint 30 cents: quart 50 cents. By express, quart 40 cents, peck $\$ 2.35$.

\section{Select Peas.}

ULTURE.-Sow in earliest spring, and for successional plant at intervals of ten days until July. For autumn early varieties in August. Make ro ches deep. For home garden sow in double rows, 10 inches

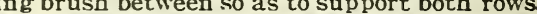

ach packet of Peas will contain 2 ounces. One pint will plant a row 75 feet long. Two to three bushels per acre.

\section{New Pea, Senator.}

his is a grand new second-early variety of special merit. of the best and most popular varieties where known. The

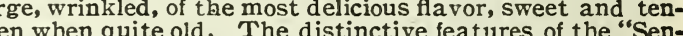
"r" are its season, second-early, handsome, large, wrinkled s, high quality, being luscious, tender and sweet; wonderlly productive. Pkt. 5 cents; pint 30 cents; quart 50 cents.

\section{Sutton's Excelsior.}

is an extra early, dwarf growing variety that is the lead. variety among the English market gardeners, where it is largely as a first crop sort. Grows 12 to 14 inches high require any brush. It is wonderfully productive being crowded with its large, broad, well filled pods. The peas are of most excellent flavor, and possesses the admirable quality of preserving their tenderness and superb flavor longer than most varieties. Unsurpassed for the market or home garden. Considering its extreme earliness, large size of peas, most excellent quality and great productiveness, this variety is well in the lead. (See cut on opposite page.) Price, per packet 5 cents; pint 30 cents; quart 50 cents. By express, quart 40 cents; peck $\$ 2.00$.

\section{Abundance.}

A valuable medium early wrinkled Pea, growing 18 to 24 inches high. A desirable feature of this variety is its remarkable tendency to branch out at the ground, and for this reason it need not be planted so thickly as other varieties. It is very productive, being heavily laden with long pods containing 6 to 8 large wrinkled peas of excellent quality. One of the best second-early varieties. Price, packet 5 cents; pint 25 cents; quart 45 cents. By express, quart 30 cents; peck $\$ 1.75$.

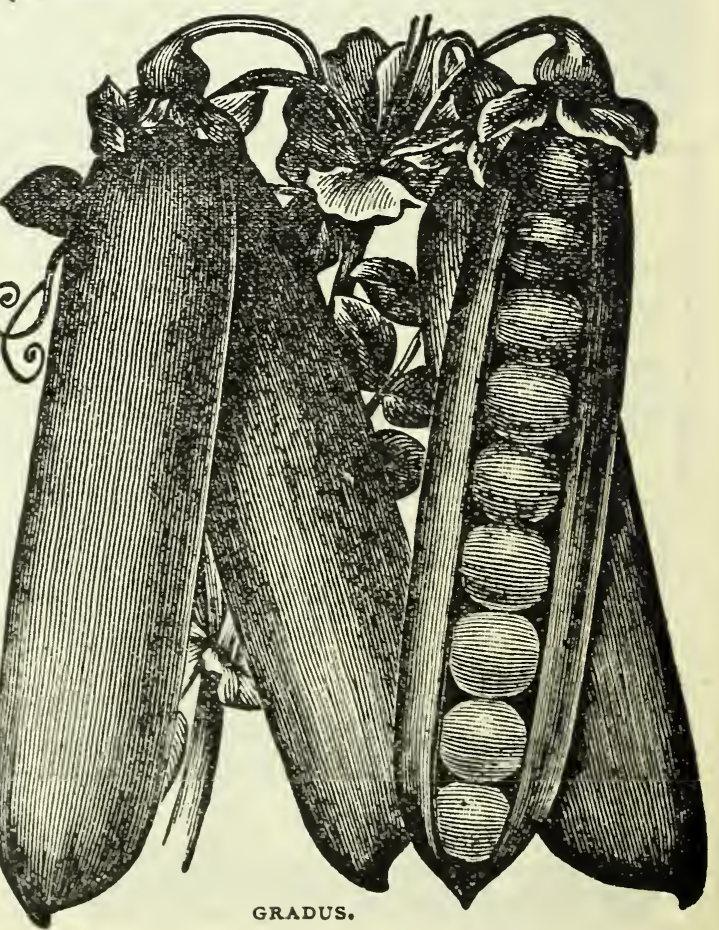




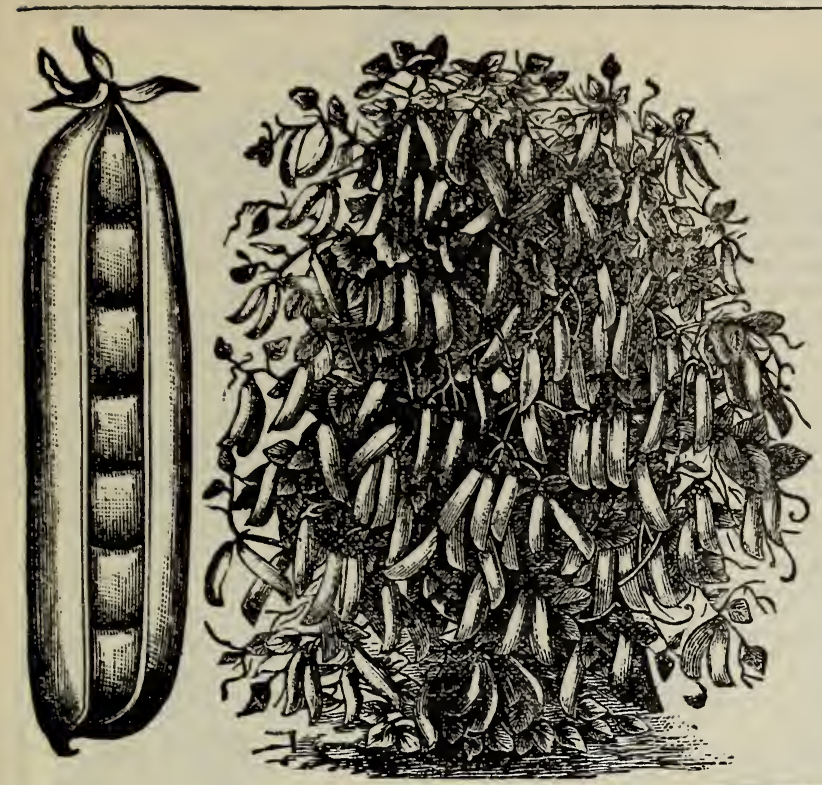

First and Best.

This is unsurpassed as an extra early variety, and is unequalled for general excellence. It is the mand farmers who know the importance of being first in know the importance of being first in smooth variety, remarkable for its quick maturity. It is uuequalled in earliness, size of pods, productiveness, high quality, vigor and regularity of growth, and possesses more real points of merit than any other extra early variety. It is usually ready for market in from 42 to 45 days from date of germination. It pro duces handsome pods of great size which are always well filled. Height about 20 inches and no supports are needed. It is profitable for gardeners because it ripens very uniformly. It never fails to satisfy the grower. Packet 5 cents; pint 25 cents; quart 40 cents. By express, quart 30 cents; peck $\$ 1.65$.

\section{Alaska.}

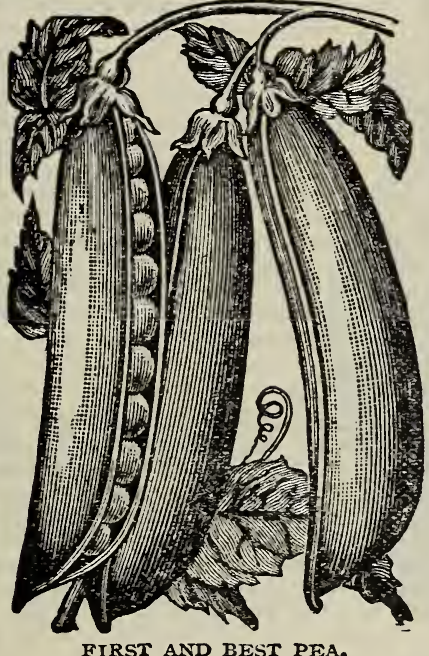

\section{Everbearing.}

A wrinkled variety that is celebrated for its excellent quality and flavor. Its season is late to very late, and it is especially adapted to summer and autumn cropping, as repeated pickings may be made, for the vines continue to produce blossoms and successional crops of pods until frost. The vines grow only 18 to 24 inches hixh, and bear in great prufusion large pods 3 to 4 inches long and containing 6 to 8 large peas. It is of re markable branching habit, sometimes forming as many as ten stalks from one root, the result of a single seed. It is very popular for the family garden. Packet 5 cents: pint 25 cents: quart 45 cts. By express, quart 35 cents; peck $\$ 1.85$.

\section{Telephone.}

One of the best tall, second-early, main crop varieties. Especially valuable for home and market gardeners, because of unusual productiveness. The vines are of robust habit, growing about four feet high, a veraging from 18 to 25 pods to the stalk. The peas are large and of pale green color, possessing a superior sugary flavor. Pods are of large size, containing 8 to 10 peas each. Of especial value for the family garden. One of the most popular varieties we offer. Packet 5 cents; pint 25 cents: quart 45 cents. By express, quart 35 cts; peck $\$ 1.85$.

\section{Carter's Daisy.}

A very fine second-early wrinkled Pea that is making friends everywhere. It is of dwarf habit, only about eighteen inches high, the stout self-supporting plants are fairly loaded with large, bright green pods, which are always well filled. The pods a verage five inches in length, broad, straight and remarkably well filled. The pods usually contain from 7 to 9 large peas, that are tender and of most delicious flavor. This variety will give satisfaction to the most critical grower. It is a dwarf early form of the popular Telephone. Packet 5 cents: pint 30 cts: quart 50 cents. By express, quart 40 cents: peck $\$ 2.00$.

SUTTON'S EXCELSIOR.

This is the hardiest Pea we are acquainted with and is well named "Alaska." On account of its extreme hardiness it can be planted earlier than any other variety, and at a time when such tender Peas as First of All and other early sorts would rot in the ground. It is also very early, maturing in from 50 to 55 days, and hence its popularity with market gardeners who wish to be first in market Pods are of good size and produced in profusion on strong healthy vines 12 to 15 inches high, and, while its quality is hardly as good as First of All, it is much ahead of other smooth extra early varieties, and is the best Pea for very early planting. Does not require any support. Those of our patrons who need an early, hardy, productive variety should order Alaska. Packet 5 centsi pint 25 cents; quart 40 cents. By express, quart 30 cents; peck $\$ 1.65$.

\section{Champion of England.}

Universally admitted to be one of the richest and best flavored Peas grown, as well as the most productive. No wonder it still retains its place as the most popular late variety. Grows about five feet high and of course much more productive than the dwarfer varieties. Price, packet 5 cents; pint 25 cents; quart 40 cents. By express, quart 30 cents; peck $\$ 1.65$.

\section{Horsford's Market Garden.}

A grand large wrinkled second-early variety, growing about 24 inches high The medium sized peas are borne in pairs, and are therefore easily picked. It is a very profitable variety for market gardeners, being enormously productive, single plant has been known to produce more than one hundred and fifty pods. It is said to have yielded more shelled peas to the acre than any other sort. It is equally good for the home garden; the quality being all that could be desired. Pkt. 5 cts; pt. 25 cts; q t. 40 cts, By express, qt. 30 cts; pk. $\$ 1.65$.

TWA NFW PFAS, See page 9. Tomas Laxton is an extremely eariy wrink tive. home gardens. They should both be included in your first order.

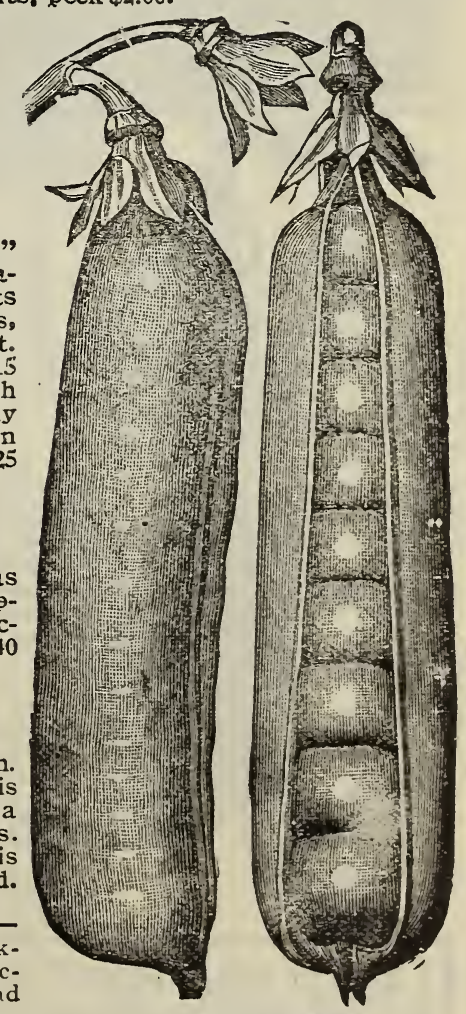




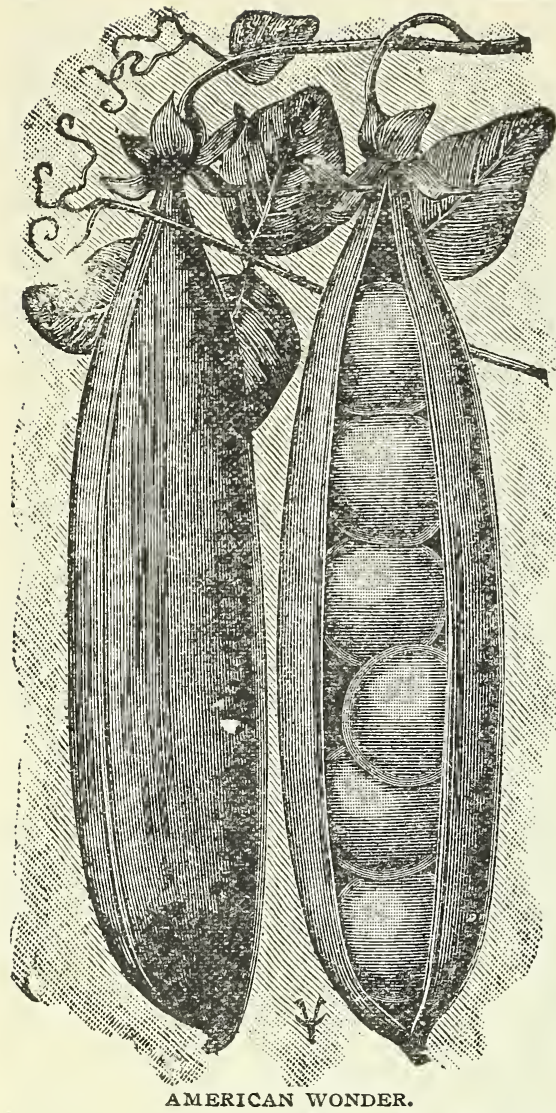

\section{Nott's Excelsior.}

This is one of the best very early $D$ warf Wrinkled Peas in cultivation. It is of fine compact habit, with pods one-third larger than those of the American Wonder, and maturing almost as early. It is so hardy and vigorous that it may be planted nearly as early as the smooth sorts. This variety has been known to be read $y$ for use.$n$ about 48 days from planting. The pods average three inches in length, are always well filled to the square ends and

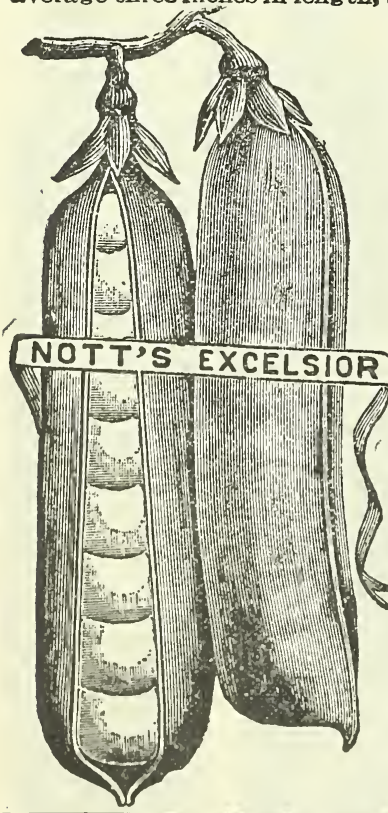
containing from seven to nine large peas. vor. It grows from 14 to 16 inches in height: the even, regular habit of the plant being a great advantage to market gardeners, as the entire crop may be gathered at two pickings and the ground planted to other crops. Nott's Excelsior has come to stay. Our strain of seed is exceptionally fine. Price, packet 5 cents: pint 25 cents; quart 40 cents. by mail, postpaid. By express, not prepaid quart 30 cents; peck $\$ 1.75$.

\section{Tall Melting Sugar.}

This splendid Sugar Pea fully maintains its reputation as a choice table variety. Instead of being shelled the pods are eaten like snap beans, In flavor, brittleness
and succulence they are unexcelled. The vines attain a height of 5 to 6 feet, requiring support. The full grown pods are 6 to 7 inches long and $1 \frac{1}{2}$ inches broad, being produced for a considerable period. The sweetness and tenderness of the edible podded Peas will be greatly a ppreciated by all those who relish snap beans. They have a distinct flavor, peculiarly their own. Packet 10 cents; pint 30 cents; quart 50 cts, postpaid. By express, not prepaid, quart 40 cents. (See illustration above.)

\section{Dwarf Melting Sugar.}

You can only appreciate the luscious fla vor of the Dwarf Melting Sugar Peas after having given it a trial. We know this variety will be of special interest to all lovers of edible podded Peas who cannot grow the tall kinds. It is of dwarf bushy habit, a veraging 12 to 15 inches high and of strong upright growth. It is very productive; will bear close planting and requires no sticlis or brush for support. The pods are always well filled, and when coolied are delicious, wholesome and equal to the best snap beans. The peas when ripe are smooth, light cream in color. This variety can be planted very early in the spring as it is quite hardy and withstands the cold and damp weather better than ordinary garden peas. Pkt. 5 cts: pt. $30 \mathrm{cts}$; qt. $50 \mathrm{cts}$.

A BUCKET SPRAY PUMP is not particularly necessary in growing Peas, but there are numerous other uses to A BUCKET SPRAY PUMP which it could be put, by the home and marhet gardener, such as spraying vines, shrubs and trees to kill insects and fungus; the poultry house for lice, the buggy for mud; the windows for dust and cobwebs. THE TEMPLIN BUCKET SPRAY PUMP, with the BORDEAUX NOZZLE, is unexcelled. 


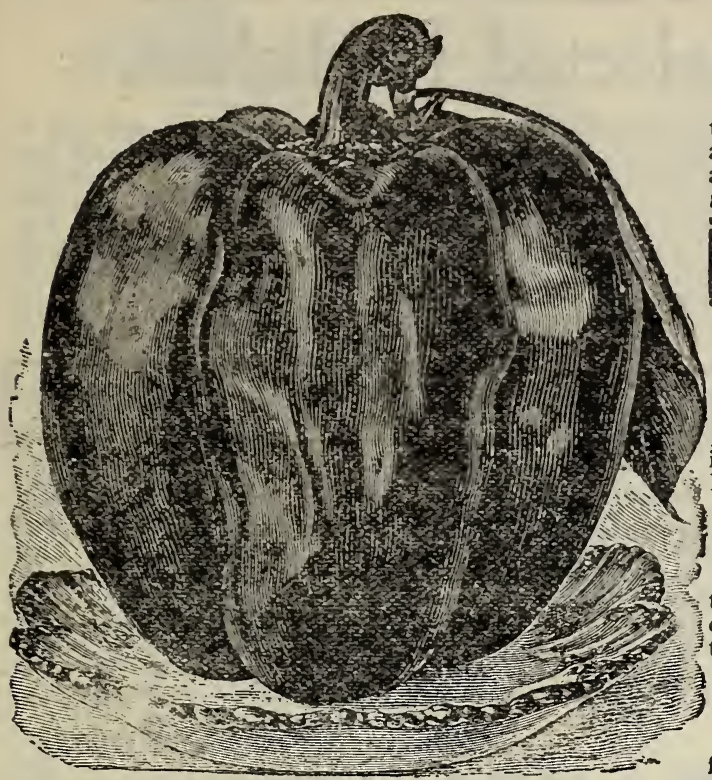

\section{Choicest Peppers.}

CULTURE.-Sow the seed in a hot-bed during A pril and transplant to the open ground when the weather is favorable. They should be planted in warm, mellow soil, in rows about 18 inches apart. They may also be sown in the open ground when all danger of frost is past.

Each packet will contain about 300 seeds. One ounce will produce about 1,500 plants.

\section{Golden Queen.}

To say that this is a yellow "Ruby King" is the highest raise that could be given. Decidedly the best yellow Pepper grown. Always large, sometimes reaching five to six inches in diameter. It is very productive: as mild as Ruby King. Pkt. $5 \mathrm{cts}$; ounce $30 \mathrm{cts}$; 1/4 pound $85 \mathrm{cts}$.

\section{Sweet Mountain.}

A mammoth variety, somewhat larger and milder than the old Bull Nose, but otherwise very similar. Very pro ductive. Color dark green, turning red when ripe. One of the best. Pkt. $5 \mathrm{cts}$; ounce $20 \mathrm{cts} ; 1 / 4$ pound $65 \mathrm{cts}$.

\section{Red Cherry.}

A small round variety of dwarf híbit: scarlet in color,
rming pretty ornamental plants. Fruits very hot: valu-
ble for seasoning pickles, Pkt. $5 \mathrm{c}$; oz. $25 \mathrm{c}$; 1/4 lb. $75 \mathrm{c}$. NEW CHINESE GIANT PEPPER. (SEE PAGE 9,)

\section{Ruby King.}

Considered the best variety grown. The plants grow about two feet high and produce fine crops of handsome, large, scarlet fruit. Ripens earlier than any other large variety. Flesh thick, sweet and mild. Especially fine for salads or stuffed for mangoes. Pkt. $5 \mathrm{cts}$; ounce $25 \mathrm{cts} ; 1 / 4$ pound $75 \mathrm{cts}$.

TABASC0. Tabasco Sauce has become the most popular for favoring soups, meats, etc. The little bright red fruits, about an inch long, are produced in sprays on large bushes. Extremely hot and fiery in flavor. Pkt. 5c; oz. $50 \mathrm{c} ; 1 / 4 \mathrm{lb}$. $\$ 1.25$.

CHINESE CELESTIAL. This variety comes from China, and is a wonder among Peppers, as it is not only useful, but the most beautiful plant grown. Exceedingly productive, often bearing 100 to 200 little fruits. In color it is creamy yellow, changing to briliiant scarlet when ripe. Pkt. $5 \mathrm{c}$; ounce $25 \mathrm{c}$; $1 / 4$ pound $75 \mathrm{c}$.

CORAL GEM BOUQUET. One of the most beautiful varieties. Of dwarf, compact, symmetrical habit, completely covering itself with hundreds of small bright coral-red fruits. giving it the appearance of a bouquet of corals. Fruits intensely hot; valuable for culinary purposes. Pkt. $5 \mathrm{cts}$; ounce $35 \mathrm{cts} ; 1 / 4 \mathrm{lb}$. $\$ 1.00$.

RED CAYENNE. Long, slim, pointed pods; bright coral-red when ripe. Exceedingly strong and pungent. The most desirable variety for pepper sauce. Pkt. 5 cts; oz. 25c; 1/4 1b. $75 \mathrm{c}$.

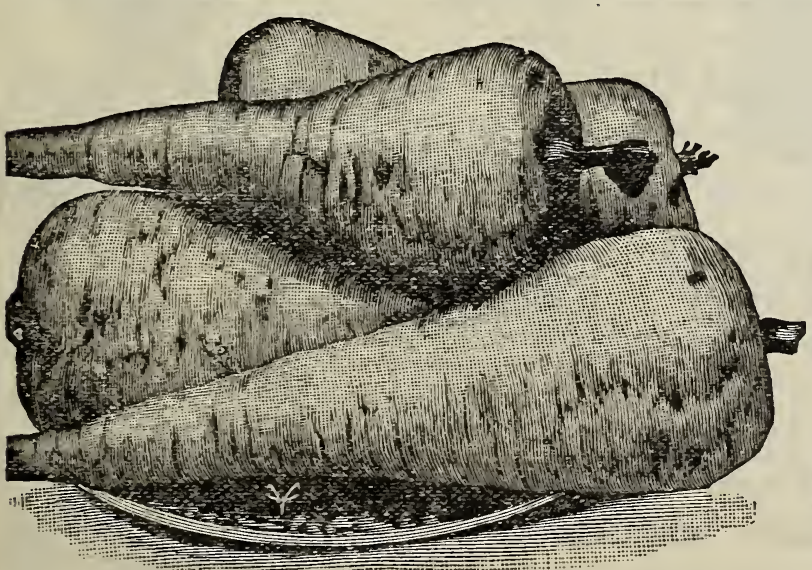

IMPROVED GUERNSEY PARSNIP.

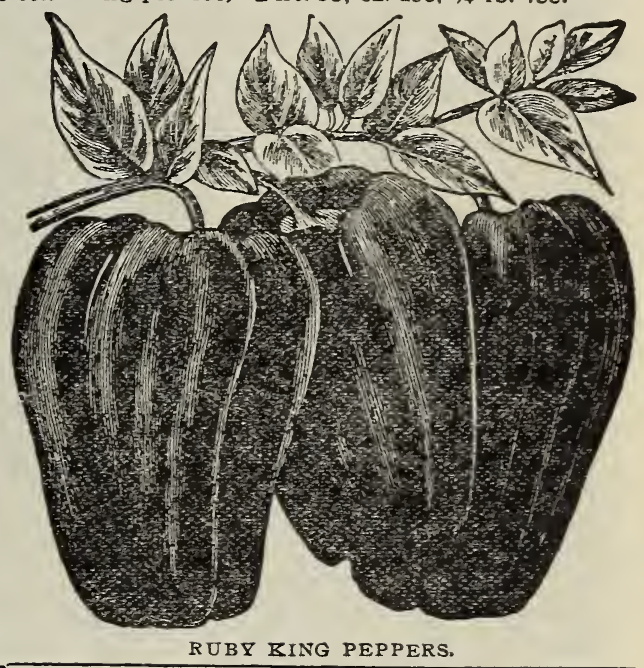

\section{Select Parsnips.}

CULTURE. - Sow as early in the spring as the ground will permit, in drills 15 inches a part and one-half inch deep, in rich, well manured ground thoroughly prepared. Thin to six inches a part in the row and cultivate same as Carrots. The roots improre by leaving in the ground until spring, securing enough in pits or cellar for winter use.

Each packet will contain 1-4 ounce, sufficient for about 50 feet of drill. From 4 to 6 pounds will plant an acre.

\section{Hollow Crown.}

This is the popular old variety that everybody grows. Roots of large size, almost smooth; rich, sweet flavor. Enormously productive. Largely grown for stock, but equally valuable for table use. Packet 5 cents; ounce 10 cents; $1 / 4$ pound 20 cents; pound 60 cents. By express, pound $50 \mathrm{cts}$.

\section{Improved Guernsey.}

We consider this the best Parsnip for both the home and market garden. The roots are smoøth; flesh fine grained and of excellent quality. It is an exceedingly heav 5 cropper. The roots a re larger and smoother than Hollow Crown, therefore easier to harvest. Pkt. $5 \mathrm{cts}$; ounce $10 \mathrm{cts}$ : $1 / 4$ pound $20 \mathrm{cts}$; pound $60 \mathrm{cts}$. By express, pound $50 \mathrm{cts}$.

A Giant Pepper. The Chinese Giant Pepper will be found described and priced on page 9 : illustration at being unequaled for mangoes, The plants are vigorous, stocky and well branched. It always gives satisfaction. 


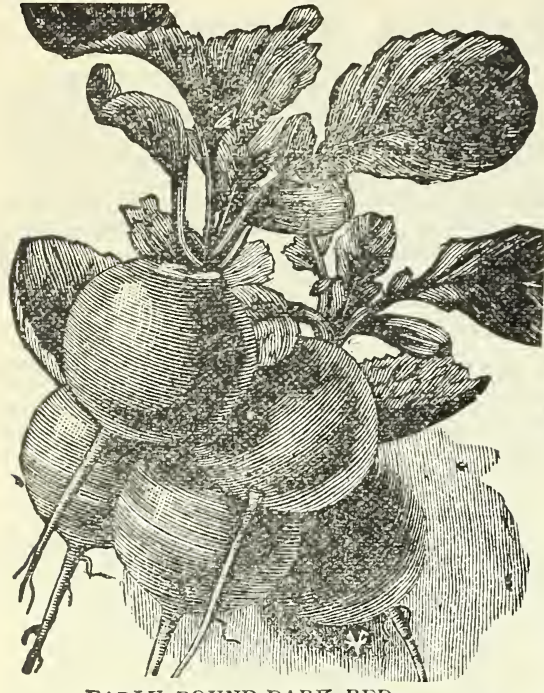

EARLY ROUND DARK RED.

Rosy Gem.

One of the earliest varietier grown. Very handsome, bein! perfectly globe-shaped. It is a rich deep scarlet at the top, beau tifully blended into pure white a ? the bottom. Exceedingly tender and crisp. Flavor very mild and aelicious. A very desirable variety for both the home and mar ket garden. A gem in earliness, beauty and quality. Pkt. 5 cts; cts. By express, 1b. 65 cts.

\section{French Breakfast.}

This pretty Radish is brigh red tipped with white. Oblon in shape, crisp and tender. It i a quick grower and is still exceedingly popular. Probably the most popular $\mathbf{R}$ adish ever introduced. It is one of the best early Radishes for family use. Fo many years it has stood in th first rank as a quick maturing. verv high quality and attractive Radish for both home and mar ket gardeners. $1 / 4$ pound 25 cents; ib. 75 cts. By express, 1b. 65 cts.

\section{White Tipped Scarlet Ball.}

This is, without doubt, one of the earliest scarlet varieties. Perfectly globular, with rich scarlet top, blending with pure waxy white at the bottom. Medium size and most excellent quality. Fine for early forcing and equally desirable for early planting in the garden. Packet $5 \mathrm{cts}$; ounce $10 \mathrm{cts}$; $1 / 4$ pound $30 \mathrm{cts}$; pound $90 \mathrm{cts}$. By ex. $1 \mathrm{~b} .80 \mathrm{cts}$.

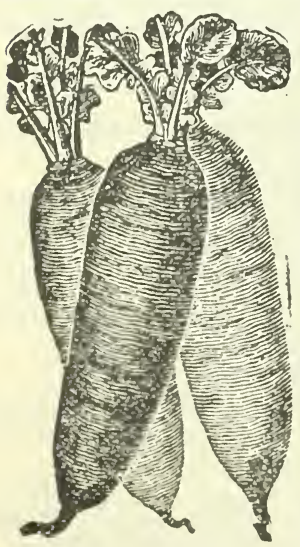

BLACK SPANISH.

\section{Early Long Scarlet Short Top.}

A very handsome and desirable early variety for the market and home gardener. They grow straight and smooth, and from six to seven inches in length. The flesh is very tender, crisp, mild and delicious in fla vor and never become pithy or stringr. The skin is very thin and is of the most attractive and brightest scarlet color. It matures beautiful Radishes in from 25 to 30 days from sowing of the seed. It is the standard long scarlet variety for the early market. Packet 5 cents. ounce $10 \mathrm{cts} ; 1 / 4$ pound $25 \mathrm{cts}$; pound $75 \mathrm{cts}$. By ex. $1 \mathrm{~b} .65 \mathrm{cts}$.

\section{Black Spanish.}

This is one of the hardiest varieties. Excellent for both autumn and winter use. They are ling, smooth, tapering in form the skin is dark brown, almost black; flesh firm and pungent, Highly esteemed in many sections. Paclet $5 \mathrm{cts}$; ounce $10 \mathrm{cts}$; $1 / 4$ pound $25 \mathrm{cts}$; pound $75 \mathrm{cts}$. By express, pound $65 \mathrm{cts}$.

OUR PRICES. All Seeds offered in this catalogue will be - sent by mail, postpaid, at the prices quoted except where prices are given "by express;" these are not prepaid, Special prices quoted on Seeds in larger quantities.

\section{Chinese Rose.}

arand winter Radish. Very opular where known. It is large blunt rooted; the part above the round darker rose than that be(lizes 3 to 5 inches long: the Pkt. $5 \mathrm{cts}$ : oz. $10 \mathrm{cts} ; 1 / 4$ ib $25 \mathrm{cts}$ : b. $75 \mathrm{cts}$. By express, $1 \mathrm{~b} .65 \mathrm{cts}$.

\section{Earliest White.}

This is not only the earliest White Radish, but the earliest of any color, good sized Radishes being produced in from 20 to 25 purest sowing. They are the the illustration, and very tender and crisp. The tops are very small, which renders them suitaind admits of very

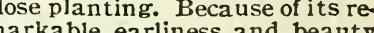
is valuable for both the home nd market gardener. Pkt. $5 \mathrm{c}$;

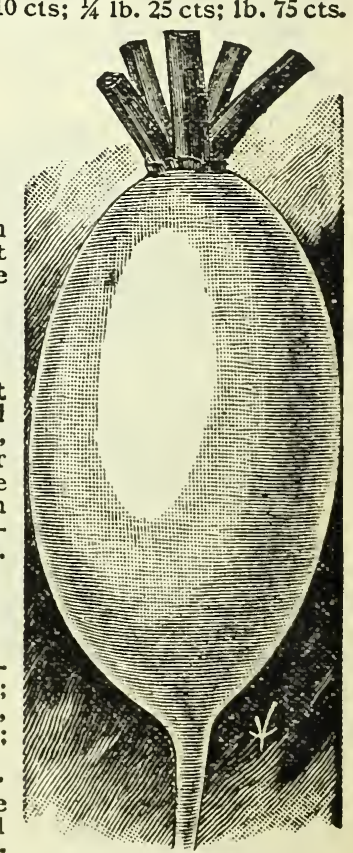

EARLIEST WHITE. 


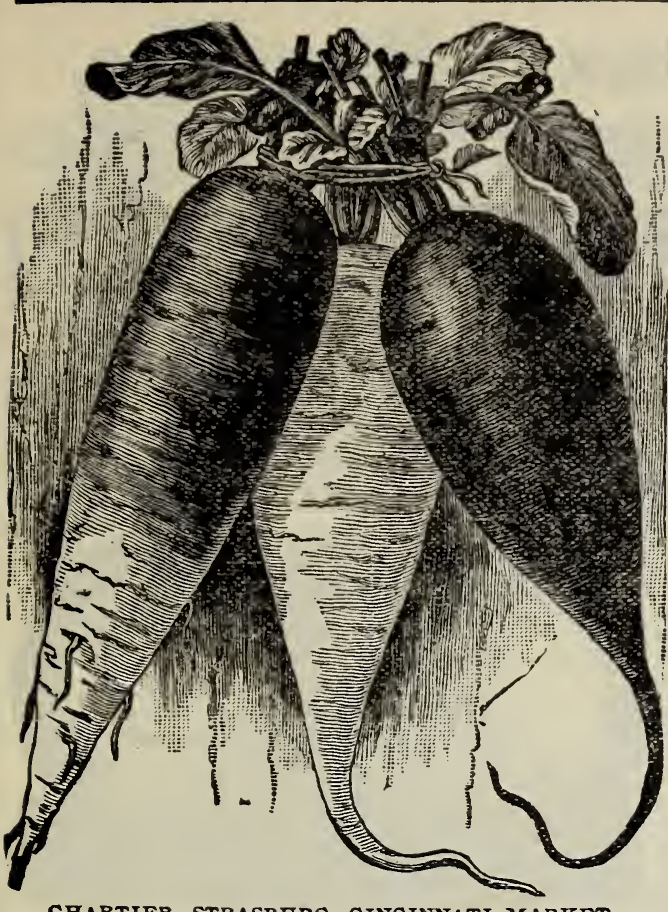

\section{Chartier.}

A very distinct, exceedingly handsome and attractive variety. It is long, smooth, beautiful scarlet-rose above the ground, shading to clear waxy-white at the tip. The accompanying illustration shows its shape. It attains a very large size before it becomes unfit for the table, and is therefore undoubtedly the best all season Radish for the open ground. While ready for use or market quite early, it remains crisp and tender for two months. When planted late it makes an excellent winter variety, keeping solid and brittle until spring. Chartier makes the finest ap pearance on the market stall and is therefore grown extensively by market gardeners. $\mathbf{P k t} .5 \mathrm{c}$; 0z. 10c; $1 / 4$ lb. 25c; 1b. 75 c. By express, 1b. 65 cts.

\section{Non Plus Ultra.}

An improvement on the old Deep Scarlet Forcing Turnip, which was considered the earliest forcing Radish in cultivation. The roots are small, round and deep rich scarlet in color. They make a very quick growth, and are ready for use in from 20 to $30 \mathrm{~d}$ ays after sowing of seed. The flesh is white, crisp and tender, and of remarkably fine quality. It is decidedly the standard red variety for the market or home gardener. The seed we offer are of the very finest strain, and are sure to prove satisfactory. $\mathrm{Pkt}$. $5 \mathrm{cts}$ : ounce $10 \mathrm{cts} ; 1 / 4$ pound $25 \mathrm{cts}$; pound $75 \mathrm{cts}$. By express, pound $65 \mathrm{cts}$.

CHARTIER, STRASBURG, CINCINNATI MARKET.

\section{Cincinnati Market.}

A superb variety of recent introduction that has rapidly gained in public favor. They grow uniformly straight and smooth, from 6 to 7 inches long. The skin is very thin, beautiful scarlet in color; flesh crisp, brittle and of delightful mild flavor. The tops are quite small and will therefore stand close planting. It remains in good condition for use longer than most o: her varieties. Pkt. $5 \mathrm{cts}$; ounce $10 \mathrm{cts}$; $1 / 4$ pound $25 \mathrm{cts}$; pound $75 \mathrm{cts}$. By express, pound $65 \mathrm{cts}$.

\section{White Strasburg.}

One of the most satisfactory varieties grown. Of large size, producing uniform, long, smooth, pure white roots of most excellent quality. It is alwass solid and crisp, and resists heat to a remarkable degree. A splendid variety for both summer and autumn use. Packet $5 \mathrm{cts}$; ounce $10 \mathrm{cts} ; 1 / 4$ pound $25 \mathrm{cts}$ pound $75 \mathrm{cts}$. By express, pound $65 \mathrm{cts}$.

\section{Early Crimson Giant.}

A new variety suitable for forcing or early spring planting out of doors. It will grow double the size of other round red forcing $R$ adishes and still remain solid. The bulb varies from round to almost oval, but the bright, deep crimson color of the skin is quite uniform and constant. Very desirable for market gardeners on account of its beauty and merit. of very mild flavor. An ideal Radish. Packet $5 \mathrm{cts}$; ounce $15 \mathrm{cts}$; $1 / 4$ pound $30 \mathrm{cts}$; pound $\$ 1 . \mathrm{C} 0$. By express, pound $90 \mathrm{cts}$.

CHINESE CELESTIAL. An old variety but positively unexcelled in size and quality as a Winter Radish. See Novelty pages for description and prices.

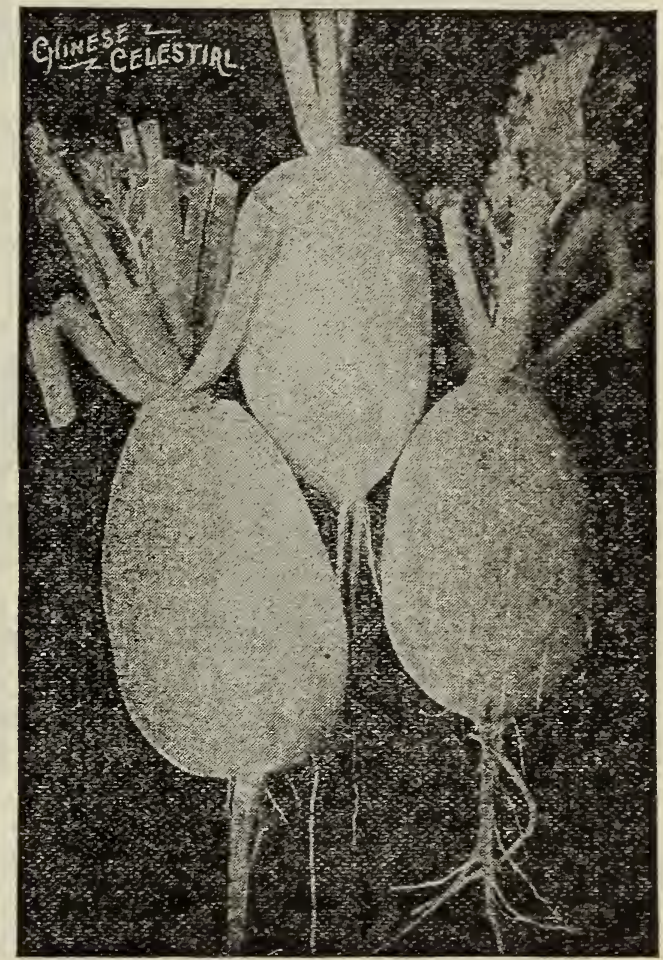

WHITE ICICLE. Long, slender, crisp, tender, mild pure white, attractive; in fact has mere really good qual. ities than any other variety. See Novelty pages.

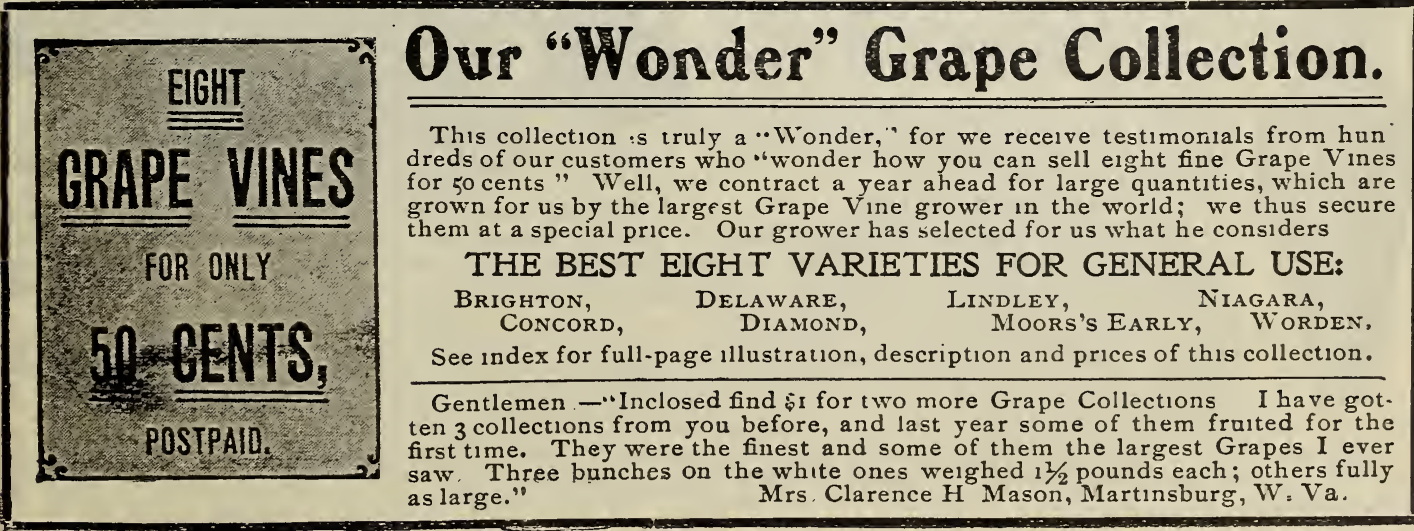




\section{Select Varieties of Pumpkins.}

CUTURE،-Pumpkins will grow almost anywhere, but for best results very fertile soil that is rich in humus is necessary. Plant in hills 8 feet apart each way. Good results mas be obtained by planting with corn, during May.

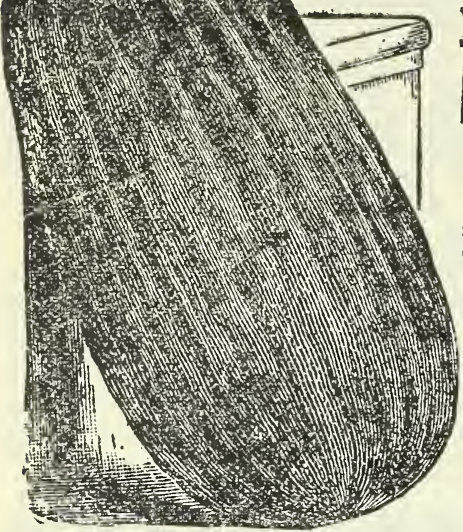

Each packet of Pumpkins will contain one-hall ounce; sufficient for 12 to 15 hills. Planted alone or with Corn, 4 to 5 pounds will plant an acre.

\section{"Lake Shore" Field Pumpkins.}

The illustration below was made from a photograph of a field of Lake Shore as grown in Northern Ohio. Without doubt the finest Field Pumpkin ever offered. They have been improved by careful selection, by a grower who has for years made a specialt y of growing. Pumpkins for eanning. If planted with Corn they are one of the most profitable crops a farmer can grow for feeding stock, if the cost of production is considered. Packet 5 cts; $1 / 4$ pound 15 cents: poutind 50 cents: By express, pound 40 centsa

\section{White Cushaw.}

This is the genuine Cushaw of "Ye olden times," and is still a general favorite. It is very hardy and of the easiest

TENNESSEE SWEET POTATO. cuiture. The skin is pure creamy-white: flesh rich yellow and of most excellent quality. It is valuable for both table use and feeding stock, Packet 5

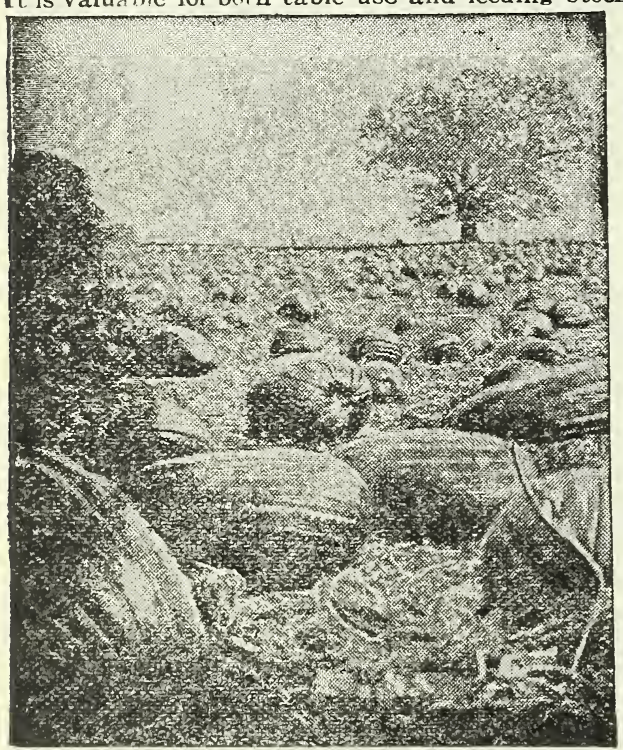
25 cents; lb, 75 cts. postpaid. $B y$ express,
pound $65 \mathrm{c}$.

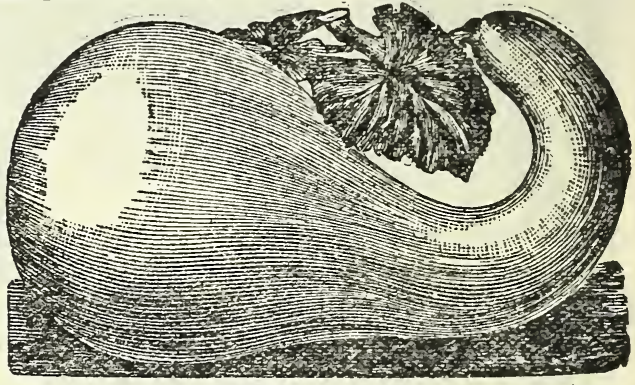

\section{King of the Mammoth.}

This variety grows to immense size, ajways à prize winnef Skin salmon jellow; flesh bright yellow, fine grained and of good quality. Though of large size it is excellent for pies. The seed we offer are of a superior strain. Pkt. 5c; 1/4 ib. $30 \mathrm{cts} ; 1 \mathrm{~b} .90 \mathrm{e}$ :

Quaker Pie. A distinct variety from N. Y. state, where it was grown in a settlement of Quakers: Shape riearly oval. Creamywhite inside and out; flesh thick; sweet: An excellent keeper. Pkt. 5 cts; oz: $15 \mathrm{cts} ; 1 / 1$ lb. $30 \mathrm{cts} ; 1 \mathrm{~b} .90 \mathrm{cts}$. By exp., 1b. $80 \mathrm{c}$.

Tennessèe Sweet Potató: Creamy-white in color, sometimes striped with green; flosh creamy-white, fine grained, thick, dry and brittle; quality the very best. For cooking this variety has no superior. Pkt. 5c; oz. 15c; $1 / 4$ 1b.30c; 1b. 90c. By exp., lb. $80 \mathrm{c}$.

Winter Luxury. Medium size, rich golden-sellow, netted like a Muskmelon. Excellent quality; good keeper. Packet 5 cts; ounce $10 \mathrm{cts} ; 1 / 4$ pound $25 \mathrm{cts}$; pound $75 \mathrm{cts}$. By exp., pound $65 \mathrm{cts}$.

New Golden Oblong. Golden-rellow; flesh dry and sweet: excellent for pies. A fine variety, averaging 15 to 18 inches in length and 7 to 8 inches in diameter. Good keeper. Price same as above.

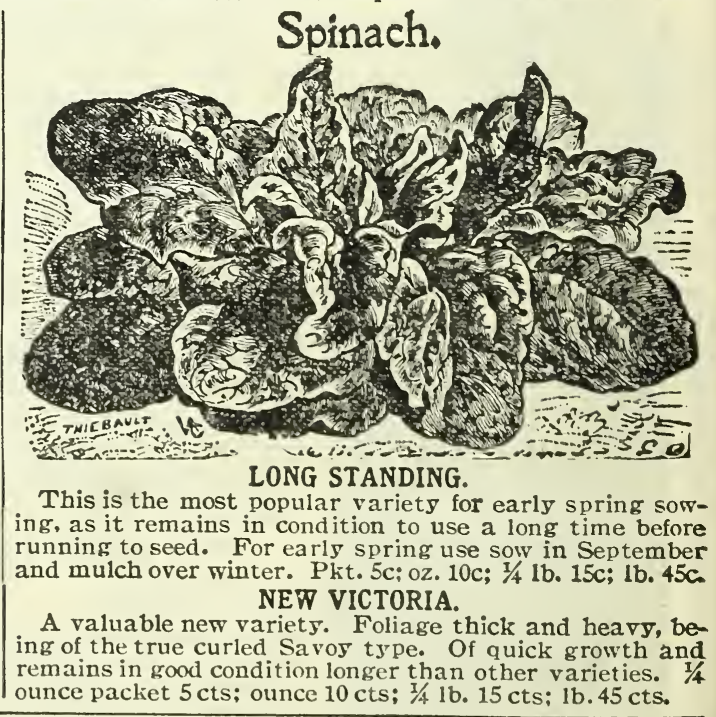

"LAKE SHORE" FIELD PUMPKINS.

\section{Salsify, or Vegetable Oyster.} WISCONSIN GOLDEN.

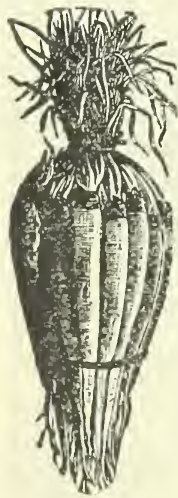

This variety oricrinated with a market gardener in Southern Wisconsin. In habit of growth it is unlike the other varieties the leaves being dark green, finely crimped the curled. The roots have a slightly yellowish tinge. When prepared for the table it has a quality which for delicious flavor, extreme richness and tenderness is unexelled. Pkt. 5 cts; ounce 20 cts; $1 / 4$ pound 50 cents; pound $\$ 1.50$

\section{SANDWICH ISLAND.}

This splendid Mammoth Salsify grows to a uniformly large size, a veraging fully double the size and weight of the old var ety. The roots, though of enormous size flavor. Truly a variety of great merit Packet 5 cents; ounce 20 cents; $1 / 4$ pound 50 cents; pound $\$ 1.50$.

Gentlemen: "Mr. Jenkins wants me to tell rou of our success with the Lake Shore Pumplins bought of you last year. The largest weighed $72 \frac{1}{2}$ pounds. We put them th the field with our corn and got 27 tons from the five acres." 


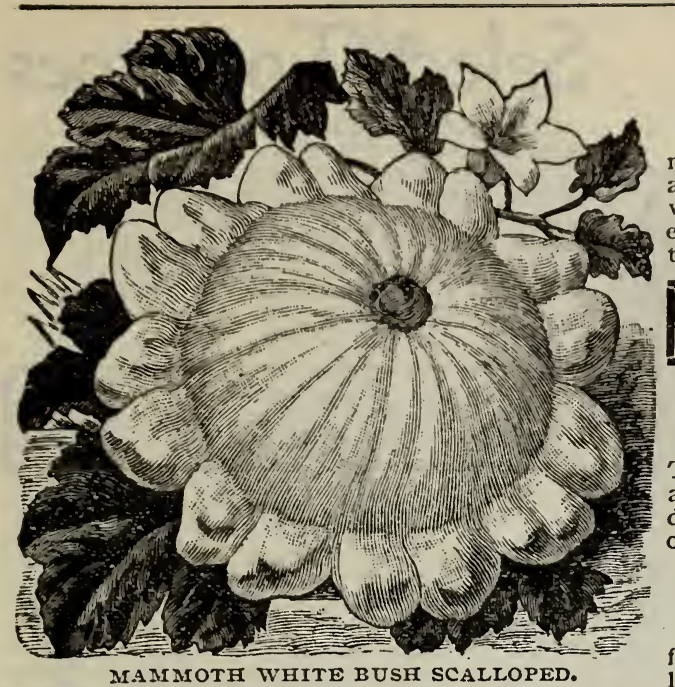

\section{Summer Squashes.}

CULTURE.-Squashes a re all quite tender, therefore should $\mathrm{n} n:$ be planted until the ground is quite warm. We plant here about the first of June. Make hills about 4 feet apart for bush varieties and 6 to 8 feet apart for vining sorts; 2 to 3 plants to each hill. Use the summer varieties while young: winter varieties are not at their best until fully ripe.

Each packet of Squashes will contain 1-2 ounce; sufficient to plant 10 to 20 hills. From 4 to 5 pounds will plant an acre.

\section{Mammoth White Bush Scalloped.}

An improved type of White Bush Pattypan, being earlier. The illustration shows the characteristic shape. 'They attain a size of 12 to 15 inches in diameter. Skin white, and quite tender when ready for use. Of dwarf, bushy habit. Packet 5 cts; oz $10 \mathrm{cts}$; $1 / 4$ pound $25 \mathrm{cts}$ : pound $75 \mathrm{cts}$. By ex. $1 \mathrm{~b} .65 \mathrm{cts}$.

\section{New Bush Fordhook.}

The original Fordhook is a strong vining variety, growing from 12 to 15 feet. The Bush Fordhook is a new type that grows like the common Pattypan. It is fully as productive as the orMAM. BUSH SUMMER CROOKNECK. See page 10 Not iginal and can be planted more closely. Fruits identical a new variet $y$, but a greatly improved variety of the old in size, color and quality, and equally valuable for fall and Crookneck type. We offer seeds from a superior strain. winter use. Packet 5 cents; ounce $10 \mathrm{cts} ; 1 / 4 \mathrm{pound} 25 \mathrm{cts}$; See page 8 for description, illustration and prices.

\section{Autumn and Winter Squashes.}

\section{True Fordhook.}

Of vining habit and a vigorous grower. One of the earliest of the winter varieties, yet if stored in a cool, dry place will keep until June. Skin light yellow: flesh very dry, sweet and of delicious flavor. Fruits are oblong, 8 to 10 inches long, slight1y ribbed: skin smooth and so thin that it need not be removed for cooking. Can be used at any age. Pkt. $5 \mathrm{cts}$; ounce $10 \mathrm{cts}$. $1 / 4$ pound $30 \mathrm{cts}$; pound $90 \mathrm{cts}$; By ex. $1 \mathrm{~b} .80 \mathrm{cts}$.

\section{True Hubbard.}

This is the popular old favorite, and still retains its position as one of the best winter varieties grown. The skin is rough, very dark green; flesh golden yellow, fine grained whether boiled, stewed or baked, and is always richly flavored, sweet and dry. Good as a Sweet-Potato. Vines vigorous and very productive. Packet $5 \mathrm{cts}$ : ounce $10 \mathrm{cts}$ $1 / 4$ pound $35 \mathrm{cts}$; pound $\$ 1.00$. By express, pound $90 \mathrm{cts}$.

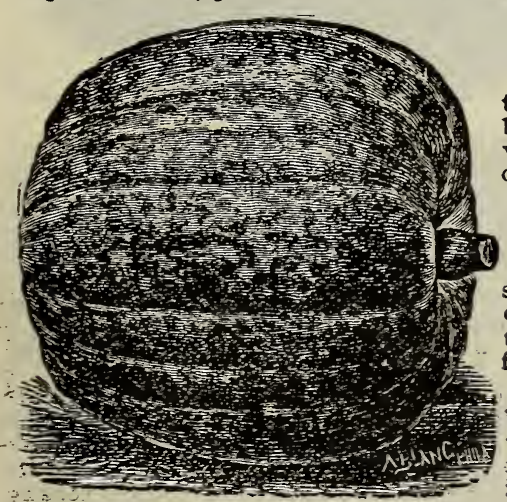

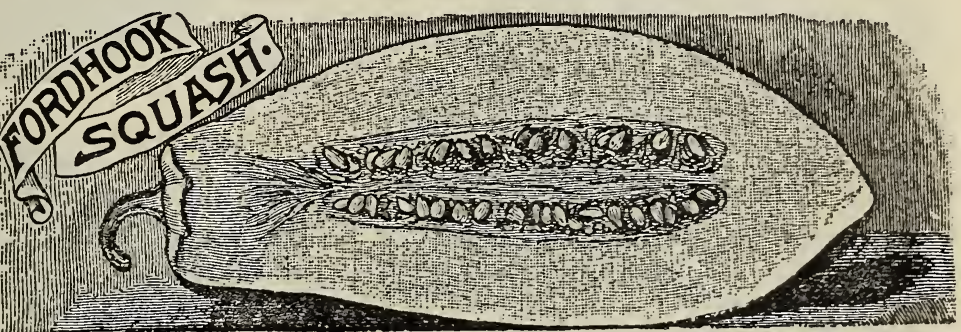

Golden Hubbard.

This splendid Squash, of recent introduction, is a sport from the well known old Hubbard, which it closely resem. bles in every respect except in color, being a bright golden orange. While it retains all the excellent qualities of the old Hubbard, it is much more vigorous and productive. In keeping quality it has no superior, keeping all winter. Pkt. 5 cts; oz. 10 cts; $1 / 4$ lb. 30 cts; 1b. 90 cts. Ex. 1b. 80 c.

\section{Mammoth Chili.}

The largest Squash in cultivation. Skin orange-yellow; flesh yellow, very thick; quality very good. As a stock food it excels the ordinary pumpkin: being more nutritious. Ordinary $\mathrm{roo}^{+}$:rops do not compare with it in lood value. Very prolific and a good keeper. Often weighs 240 pounds. See cut opposite. Packet 5 cts; ounce $15 \mathrm{cts} ; 1 / 4 \mathrm{lb} .40 \mathrm{cts} ; 1 \mathrm{~b} . \$ 1.25$. Ex. $1 \mathrm{~b} . \$ 1.15$

\section{Boston Marrow.}

A very popular variety for autumn and early winter use. Oval in form: skin very thin, bright orange-yellow. Flesh dry. fine grained and of excellent qualit 5 . Of very easy culture and unusually productive. The skin is quite th in but is a good keeper and unexcelled for pies. Will prove entirely satisfactory. Packet 5 cts; ounce $10 \mathrm{cts} ; 1 / 4 \mathrm{lb} .30 \mathrm{cts} ; 1 \mathrm{~b} .90 \mathrm{cts} . \mathrm{Ex} .1 \mathrm{~b} .80 \mathrm{cts}$

THE DELICIOUS SQUASH. See page 8. This is a fall and winter Squash, being excellent at all seasons, but it does not acquire its best quality unti winter and spring. It is positively unequaled in fineness, dryness and rich. ness of flavor. It retains its excellent qualities until spring. IVe can heartily rocommend it. Description, illustration and prices on Dage 8 .

\section{TWO EXCELLENT NEW POTATOES.}

"DAINTY-EYE.". Those who purchased this splendid variety last season are highly pleased with it; and we have iLe same high opinion of its superior quality. The illustration on page 13 shows the ideal shape of the tubers and shallowness of the eyes. The flesh is pure white, and when cooked is fine and white as flour.

"KNOXEMALL." We offered this variety last year for the first, and it is again proving fully up to the high standard set tur it. Our grower, who is an expert, again sends us word that, on the twenty acres he is now growing, this variety actually "Knoxemall" in viger and prospects for heavy yield. When once known we believe it will take tirst rank among the medium early main crop varieties. It is very vigorous, bealthy and exceedingly productive. For illustration, description and prices see page 13 . 


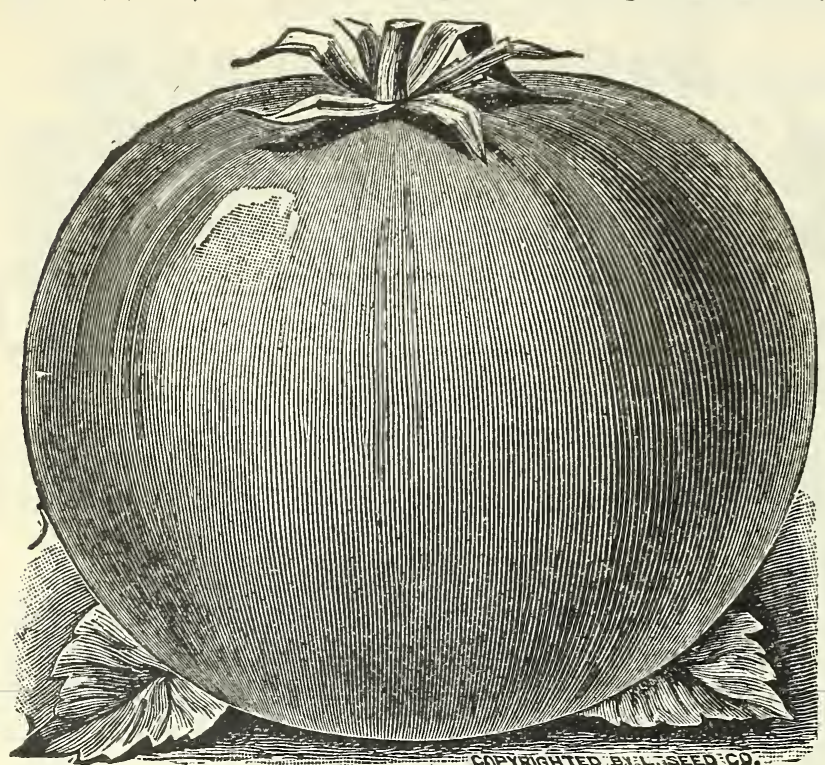

SUCCESS TOMATO.

\section{Success.}

A magnificent new scarlet Tomato. Bright scarlet, perfectly smooth and free from cracks; very meaty and fine flavor. Ripens with the second early and yields large crops. The handsome color, even size and great solidity make it an excellent market sort. Also well adapted to canners' use because of its color and solidity. Pkt. 5 cts; oz. 30 c; $1 / 41$ b. 75 c; 1 b. $\$ 2.40$. By express, pound $\$ 2.30$.

\section{Chalk's Early Jewel.}

A wonderfully early and prolific variety. Medium to large, uniform in size and shape; smooth, very solid and attractive. Color, brightest scarlet, ripening right up to the stem, without specks or green core. The thick flesh is very solid, of fine, sweet flavor. Skin sufficiently strong to make it a good shipper. In the Tomato growing section of Southern New Jersey it has proven to be the "first in market." Our seeds are of the finest strain. Pkt. 5 cts: oz. 35 cts; $1 / 4$ pound $\$ 1.00$; pound $\$ 3.25$. By express, pound $\$ 3.15$.

\section{Matchless.}

In beauty of coloring and symmetry of form it is indeed worthy of its name. Of strong, vigorous growth; foliage very rich dark green. Fruit entirely free from core, of a rich cardinal-red color, and not liable to crack in wet weather; are of largest size, and uniformly large throughout the sea. son. The flesh is so firm that ripe fruit picked from the vine will keep in inarketable condition for two weeks. Pkt. 5cts; Marchress. oz. 25c; $1 / 41$ b. 75c; 1 b. $\$ 2.10$. By express, pound $\$ 2.00$.

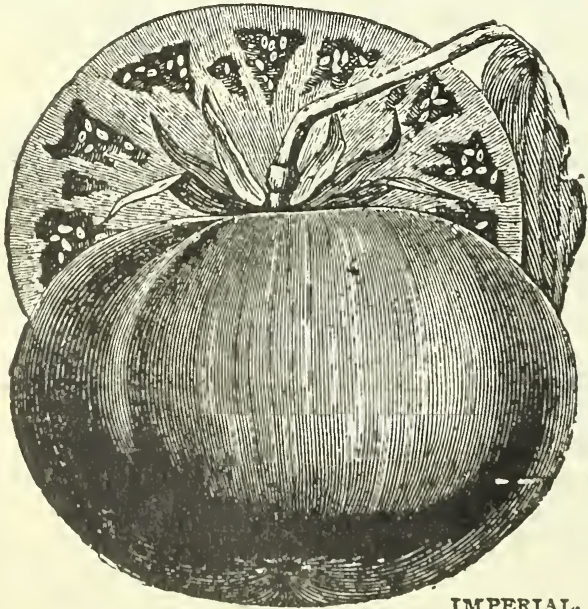

\section{Crimson Cushion, or Beefsteak.}

This is a Tomato of surprising beauty. Fruits vers large and smooth. The fruit ripens all over, even the stem end coloring. Like the Ponderosa it is almost seedless. and as solid as beefsteak. Fine form, uniform shape, beautiful in a ppearance and excellent in fia vor Plants are enormously productive. An exceptionally fine varietr for market gardeners. $5 \mathrm{c}$; oz. 35c: $1 / 4 \mathrm{lb} . \$ 1.00 ; 1 \mathrm{~b} . \$ 3.25 \mathrm{Exp}, 1 \mathrm{~b} . \$ 3.15$

\section{Imperial.}

We have grown this Tomato for two years and think it one of the best. Fruit large, always solid and smooth: color, purplish-crimson; ripens medium early. One of the best for main crop, as it not only ripens early but produces fruit until frost. One grower sass of it: "It is the earliest, handsomest. smoothest, most solid and productive Tomato in the world." It has proved its ad aptability to all sections of the country, and is now a standard in all respects. Pkt. 5 cts; $0 z$. 25c; $1 / 41 \mathrm{lb}$. 75 cts; $1 \mathrm{~b}$. $\$ 2.40$. Bs express, pound $\$ 2.30$.

Gentlemeu: "I have been using the Houser Cabbage and Earl. iana Tomato for several years, and would not think of exchang. ing them for any other. I am perfectly willing that you use my name in testimony of the high quality of your Seeds."

Mrs. Thos. Blincoe, Sterling, Va. 


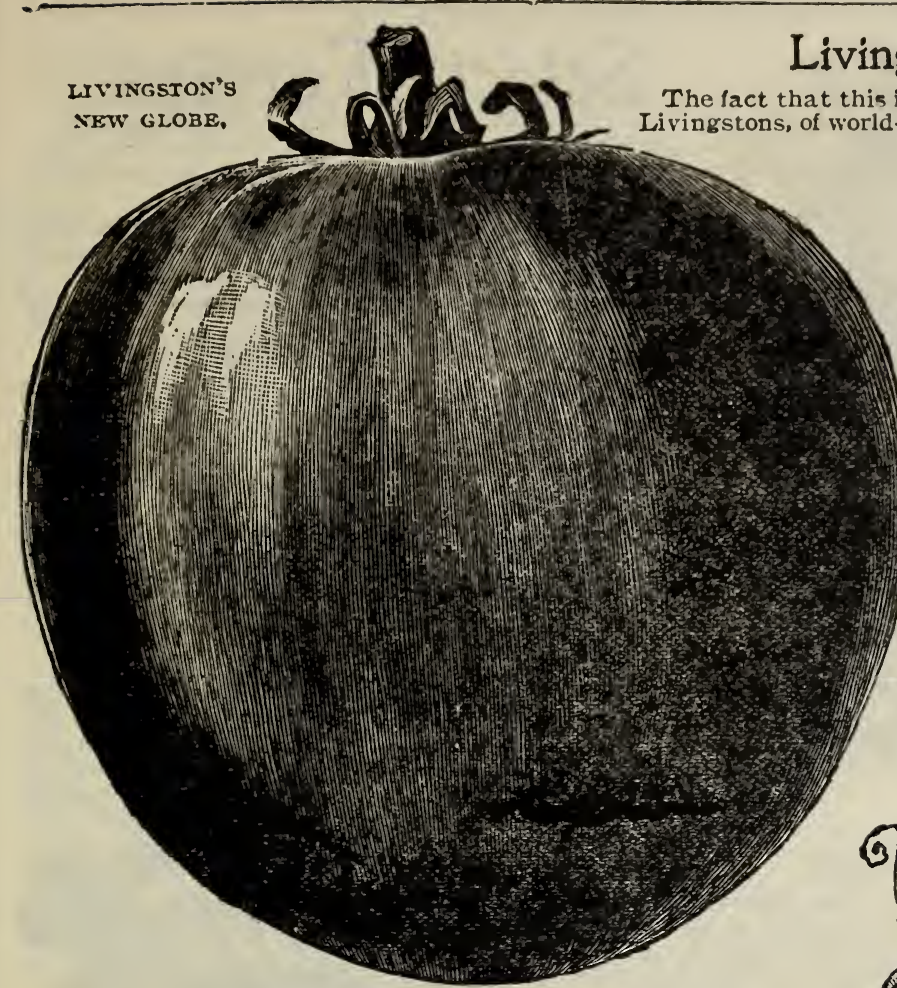

Livingston's New Globe.

IIVINGSTON's The fact that this is another new Tomato originating from the NEW GLOBE, Livingstons, of world-wide Tomato fame, will be sufficient to warrant most growers of fine Tomators to give
it a liberal trial. It is of beautiful globe shape, with quite a percentage of elongated (stem to blossom) fruits, which permit of a greater number of slices being taken than with flat-fruited sorts.

It is a mong the very first to ripen, although of large size; very smooth, firm fleshed, few seeds, ripens evenly; color, a beautiful glossy rose, tinged purple. Flavor very delicate and agreeable; splendid slicing variety. The fruit is borne on short-jointed, branching plants in great abundance-literally loaded with fruit. A general good cropper, and one of the very best for greenhouse growing or first-early crop on stakes or trellis. An entirely distinct and fixed new sort. Every grower of Livingston's New Globe, whether he grows for private or market purposes, wlll be pleased with the beautiful and attractive globe-shaped fruit. They will sell readily at the top price.

We purchase our seed direct from the originators, therefore they a re strictly pure and reliable. Packet 10 cents; ounce 35 cents: $1 / 4$ pound $\$ 1.00$; pound $\$ 3.10$. By express, $1 \mathrm{~b}$. $\$ 3.00$.

\section{Livingston's Beauty.}

This superior Tomato is, without doubt, the most widely known and popular of all the purple fruited varieties. A strong grower, producing enormous crops of uniformly large and smooth fruits, in clusters from 4 to 6 each. Color of skin glossy-crimson, with a tinge of purple: flesh light pink and of excellent flavor. Ripens early; seldom cracks or rots after a rain. Unexcelled for shipping. Pkt. $5 \mathrm{cts}$; oz. $30 \mathrm{cts} ; 1 / 4$ lb. $75 \mathrm{cts} ; 1 \mathrm{~b}$. $\$ 2.25$. By express, $1 \mathrm{~b}$. $\$ 2.15$,

\section{The Enormous.}

The originator claims, "It is the best all-round main crop Tomato on the market." Very solid and heavy; flesh thick and firm. color, clean deep red, with no purple tint. It is recognized as a standard main-crop Tomato of great size and productiveness. Pkt. 5 cts; oz $30 \mathrm{cts} ; 1 / 4$ lb. $\$ 1.00 ; 1$ b. $\$ 3.50$. By express, 1b. $\$ 3.40$.

\section{Golden Queen.}

This is probably the finest of the Yellow varieties. In size, solidity, productiveness and quality it will compare favorably with the red varieties. For slicing with red varieties it makes an attractive dish. Pkt. 5c; oz. 25c; 1/4 1b. 75c; 1b. \$2.25. Br exp., 1b. \$2.15.
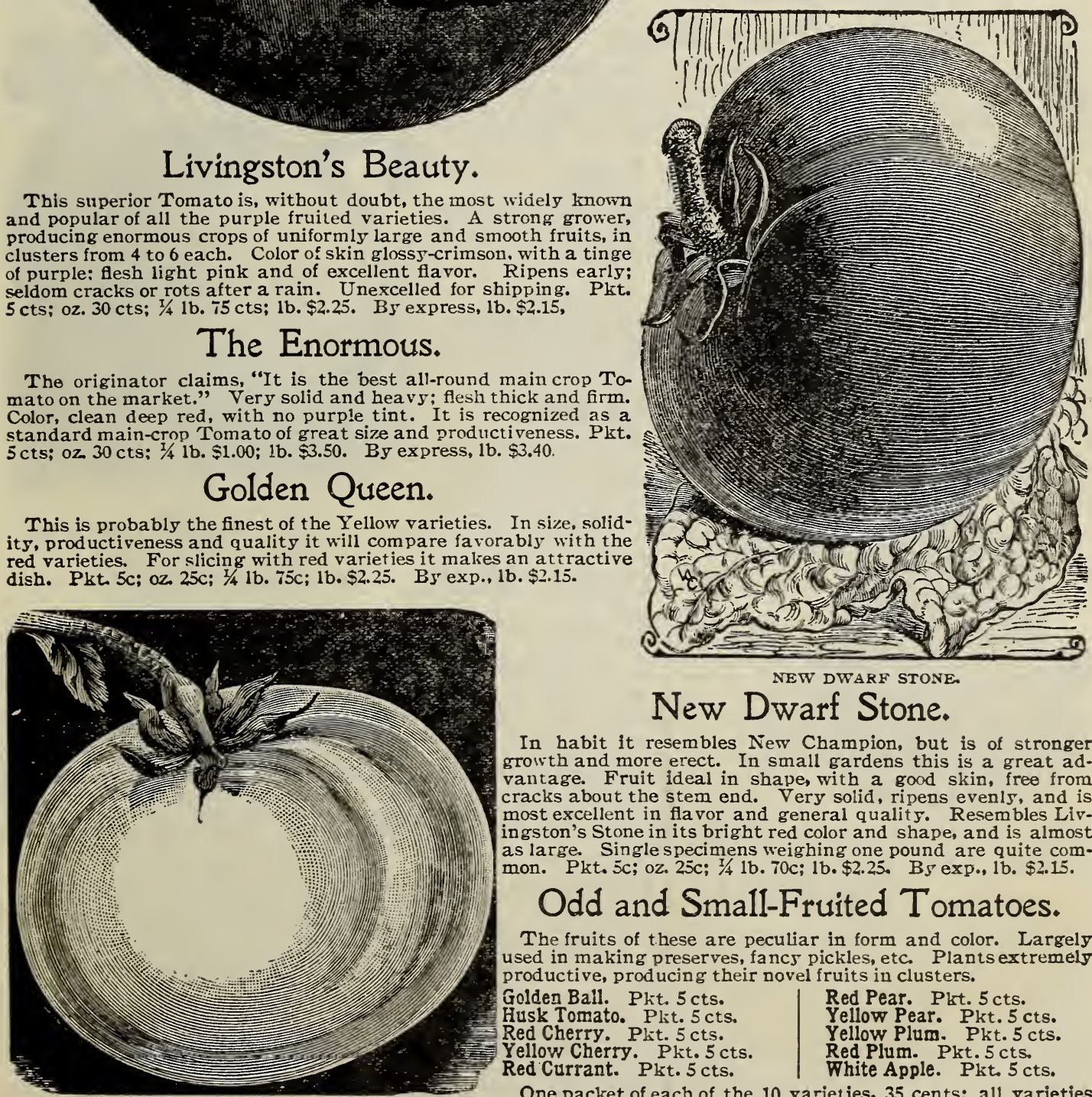

New Dwarf Stone.

In habit it resembles New Champion, but is of stronger growth and more erect. In small gardens this is a great ad. vantage. Fruit ideal in shape, with a good skin, free from cracks about the stem end. Very solid, ripens evenls, and is most excellent in flavor and general qualit 5 . Resembles Livingston's Stone in its bright red color and shape, and is almost as large. Single specimens weighing one pound are quite com. mon. Pkt. 5c; oz. 25c; 1/4 lb. 70c; 1b. \$2.25. Bs exp., 1b. \$2.15.

\section{Odd and Small-Fruited Tomatoes.}

The fruits of these are peculiar in form and color. Largely used in making preserves, fancs pickles, etc. Plants extremely productive, producing their novel fruits in clusters.

Golden Ball. Pht. 5 cts. Husk Tomato. Plit. 5 cts. Red Cherry. Plit. 5 cts. Yellow Cherry. Pkt. 5 cts. Red Plum. Pkt. $5 \mathrm{cts}$.

Red Pear. Pkt. 5 cts. Yellow Pear. Pkt. 5 cts. Yellow Plum. Pkt. $5 \mathrm{cts}$.

One packet of each of the 10 varieties, 35 cents; all varieties GOLDEN OUEEN. mixed, packet 10 cents, 


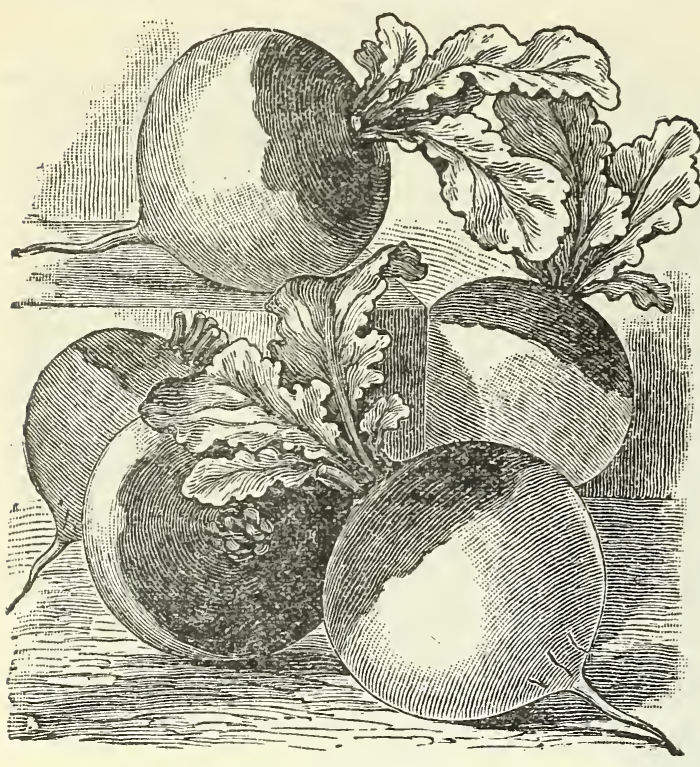

PURPLE TOP WHITE GLOBE.

\section{Extra Early IVilan.}

The earliest in cultivation; two weeks earlier than Purple Top Strap Leaf. The bulb is flat, of medium size, smouth, with a purple top. Flesh white, hard, and of fine quality; an extra good keeper. A fine early market and table variety. Always very scarce. Packet 5 cents; ounce $10 \mathrm{cts}$. $1 / 4$ pound $25 \mathrm{cts}$; pound $75 \mathrm{cts}$. By express, pound $65 \mathrm{cts}$.

\section{Early White Strap Leaf.}

A very popular flat, smooth, white Turnip held in high esteem by all growers; one of the best for the family garden in the spring. Slin clear white; flesh mild and juicy. Pkt. 5c; oz. 10c; 1/4 1b. 20c; 1b 60c. Ex. 1b. 50c.

\section{White Egg.}

A valuable variety of rapid growth. Forms a beautiful egg-shaped root, with a thin white skin. Always firm, agreeable in flavor and very desirable for table use. Excellent for either early or late sowing. Pkt. 5 cts; 0z. 10 cts; 1/4 1b. 20 cts; 1b. 60 cts. By express, 1 b. 50 cts.

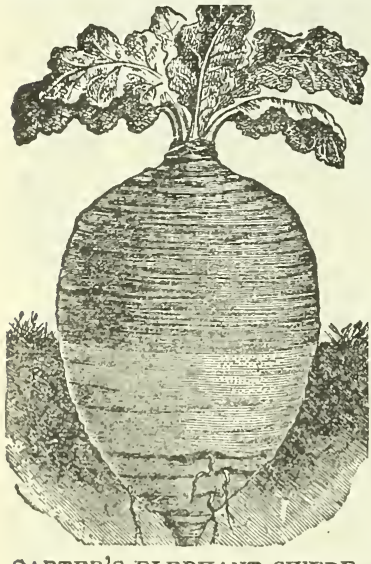

\section{Golden Ball.}

One of the richest, most delicate flavored and best of all the yellow fleshed Turnips yet introduced. It is globeshaped, matures early and an excellent keeper. Its shape and appearance are indica ted by the illustration. Pkt. 5c; oz, 10c; $1 / 4$ lb. 20c; 1b. 60c. By express, 1b. 50c.

\section{Ruta Baga, or Swedes.}

American, or Bloomsdale. Flesh yellow, solid, sweet and fine flavored: shape slightly oblong, terminating abruptly with no side or bottom roots; color, deep purple above and bright sellow under the ground. Leaves small, bright green, with little or no neck; perfect in form, rich in flavor. Very desirable for both table and stock feeding. Packet $5 \mathrm{cts}$; ounce $10 \mathrm{cts}$; $1 / 4$ pound $20 \mathrm{cts}$; pound $50 \mathrm{cts}$. By express, pound $40 \mathrm{cts}$.

Burpee's Breadstone. A very desirable variety for table use. Of quick growth and uniformly smcoth. Color of skin white, faintly colored at top; flesh white, fine grained. tender and sweet. Pkt. $5 \mathrm{cts} ; 0 z .10 \mathrm{cts} ; 1 / 4 \mathrm{lb} .20 \mathrm{cts} ; \mathrm{lb} .50 \mathrm{cts}$. By express, $1 \mathrm{~b} .40 \mathrm{cts}$.

Carter's Elephant. This fine Ruta Baga comes from England, where they are noted for growing fine Turnips. It is claimed to be the largest variety grown; 20 tons have been grown on an acre. Unsurpassed for stock feeding because of its quality and proCARTER's ELEPHANT SWEDE. ductiveness. Pkt. $5 \mathrm{cts}$; ounce $10 \mathrm{cts} ; 1 / 4$ pound $20 \mathrm{cts} ; \mathrm{lb} .50 \mathrm{cts}$. By express, $1 \mathrm{~b} .40 \mathrm{cts}$.

\section{Medicinal, Pot or Sweet Herbs.}

Sow seeds in shallow drills a foot apart. Harvest only on a dry day, just before they come into bloom. They should be packed away in air tight boxes or jars. Very easily grown from seed, and require little cure.

Anise. For garnishing and flavoring. Onnce socents. Rosemary. Aromatic leaves used for seasoning. Oz.25c. Balm. Tea is useful infevers. Ounce 15 cents. Sago. Leaves uxed in dressings and in sauces. Oz. $15 \mathrm{c}$. Basil, Sweet. Leaves valuable for seasoning Oz. 15c. S. Savory. J.eaves used for flavoring soups, etc. Oz. 15c. Caraway. Aromatic leaves used in confectionary. 1cc. Sweet Fennel. Leaves are used for garnishing. Oz. 10c. Coriander. Leaves for garnishing; seeds for "Oz. roc. Sweet Marjoram. Leaves largely used for tlavoring. I5c. Dill. Leaves used in soups, pickles, etc. Oz. Iocts. Horehound. Has tonic properties; used for coughs. $15 \mathrm{c}$ Wormwond. J,eaves medicinal. Oz. 2 cc.

Lavender. Aromatic leaves, used for perfumes. Oz. I5c. MIXED HERBS. All the above mixed. Pkt. 1oc; oz. 15c. Any one of the above varieties, packet 5 cents; any 5 packets for 20 cents, by mail, postpaid. 


\section{Seeds of Forage and Fodder Plants.}

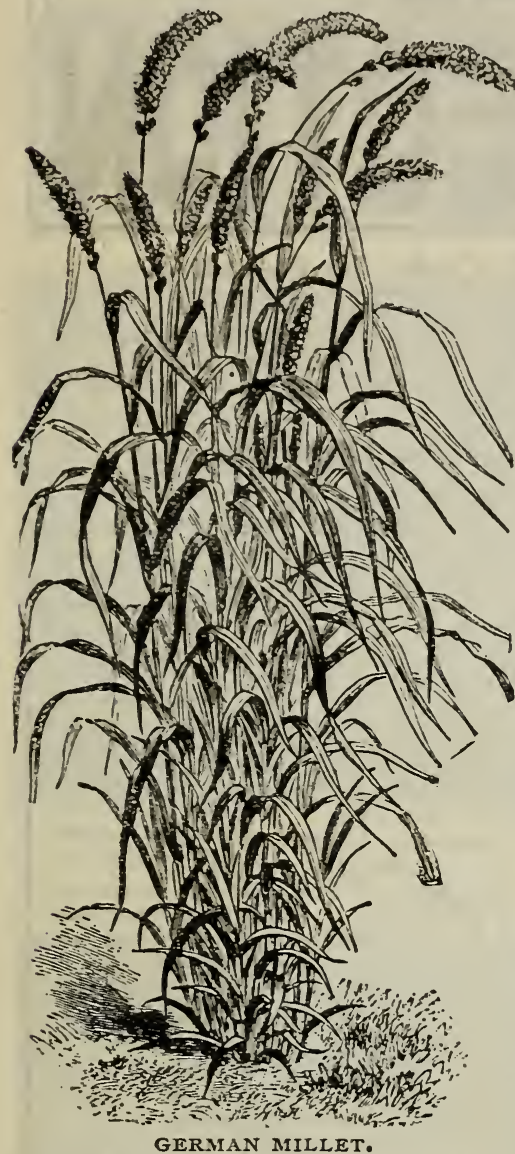

\section{German Mirllet.}

Superior to the common Millet, as it will produce nearly double the crop. It will grow in any climate or soil and make a large yield of nutritious feed. Grows from four to five feet high, vielding an abundance of leaves as shown in the illustration. Heads closely condensed; numerous. There is nothing better than Millet for sowing to make up for the shortage in your hay crop.

Prepare ground well before sowing; sow one bushel per acre, at any time between May Ist and June 15th. Cover with light harrow, or roll without harrowing; or may be sown with a wheat drill, barely covering the seed. Cut crop while in bloom, before the seed hardens. The straw and grain fed together are very nutritive stock food. It is also excellen 5 cents; 1 b. 20 cents. By express, not prepaid, peck 65 cents; bushel prices a matter of correspondence. Remit 20 cents extra for bag.

\section{Mammoth Russian Sunflower.}

Great food for poultry and hogs. Indeed one of the best paying crops that can be raised. An immense yielder; as nuch as 125 bushels of seed to the acre lias been grown, and at less expense than corn. Being very rich in oil it is very 1:utritious; better for fat and the best egg producing food known. This variety is the greatest seeder, and therefore the The stalks make gcod firewood. Pkt. 5c; lib. 20 cts. By express. peck ( 7 lhs.) 60 cts; bushel \$1.80. Bags 20 cents extra.

\section{Kaffir Corn.}

A most excellent fod. der plant, yielding two crops during the season. Has been largely grown in the Suth, and is rapidly coming into favor with the Northern farm. ers. It grows from four to six feet high, making producing enormous

broad leaves. The stalks keep green and are brittle and juicy, making excellent fodder either green or dried. The seed crop is also heavy; sometimes yielding 60 bushels to the acre. The seed is extremely valuable for feeding poultry. Very easily grown, as it possesses the quality of doing without rain, without loss of yield. Culture same as corn. Rows $2 \frac{1}{2}$ to $3 \frac{1}{2}$ feet apart. Sow

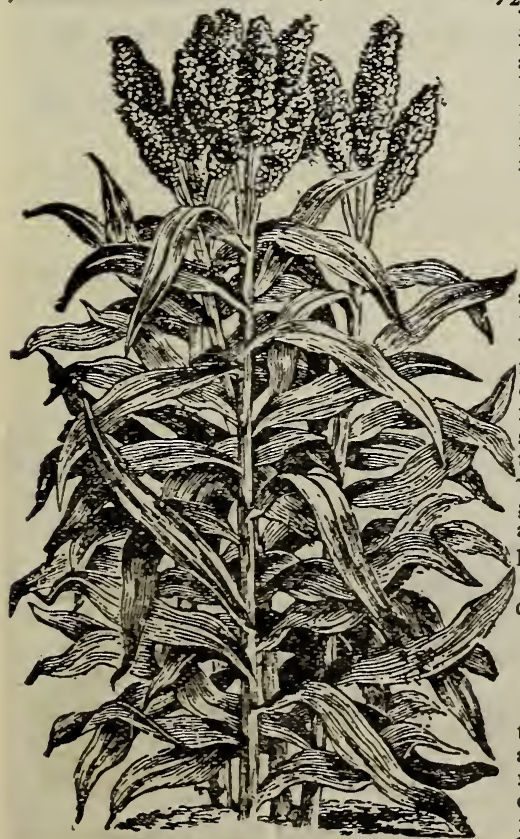
ing 5 to 10 pounds per acre. For fodder 5 ow broadcast or drill threefourth bushel per acre. Pkt. 5 cts; pound 20 cts. By express, peck 45 cts; bushel (50 lbs.) \$1.50.

\section{Rape.}

There are millions of acres of good farm land that lie idle at certain might be made to produce one of the finest

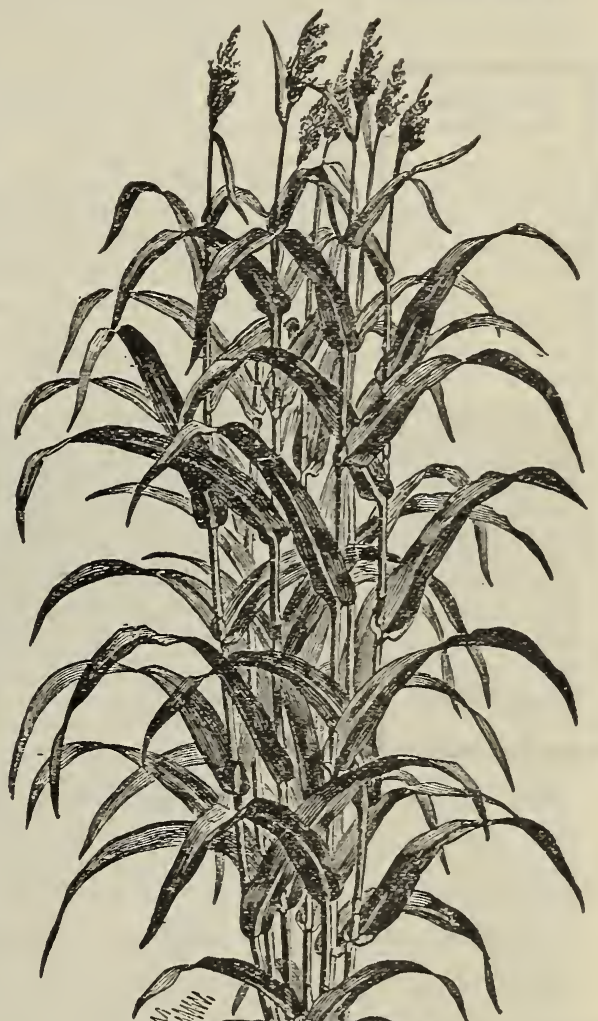
fteds possinle for cattle,

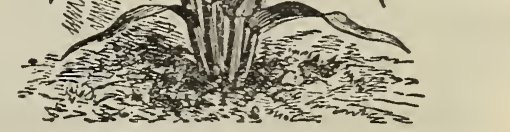

IMPERIAL SORGHUM.

fheep or hogs, or for plowing under, by sowing Dwarf Essex Rape. In the Northern States sow at any time from spring until August, but in the warmer Southern States sow from August to October. If sown after digging potatoes, or in the cornfield at last cultivation, it will produce an abundance of pasture during autumn and early winter. Sow four to six unds per acre.

Dwarf Essex. Price, 2-ounce packet 5 cts; 1b. 25 cts. Prices on larger quantities furnished on application.

\section{Imperial Sorghum.}

Grows 6 to 9 feet high; foliage long, narrow. An acre will prodnce three times as much stock food as ordiuary corn. Both fodder and seed are relished by all domestic animals. For pasture sow broadcast, or in rows 3 feet apart, hills 2 feet apart, 10 to 12 stalks per hill. It will produce enormous crops in this way. Sort from May 15 th to June 15 th, 10 to KATTIR CORA. 12 pounds per acre in rows; $1 / 3 /$ to 2 bushels per acre broadcast. Pkt. $5 \mathrm{c}$;
lb. 20c. By express, pk. 7oc; $1 / 2$ ba. $\$ 1.25 ;$ bu. $\$ 2.00$. Bags 20 cts. extra. 


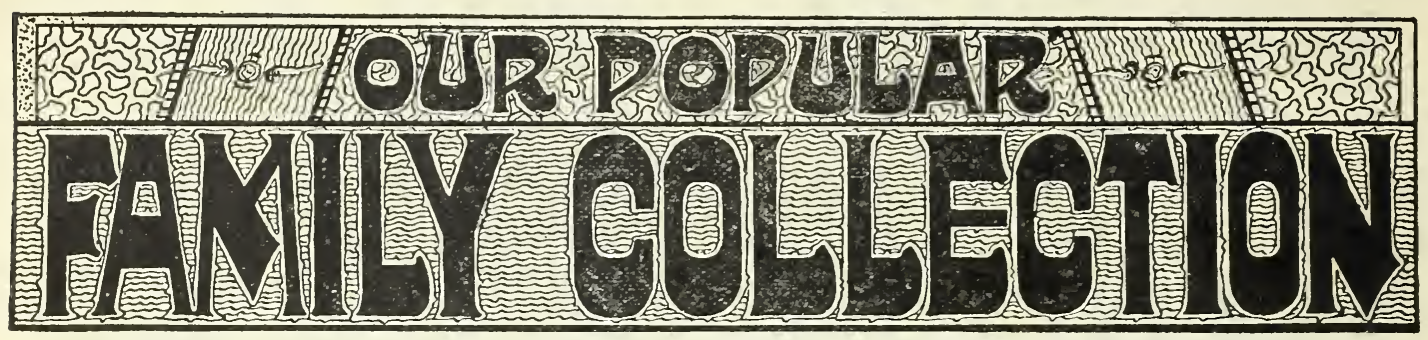

25 Choice Varieties, "Standard Packets." Only 50 Cents.

For twenty years we have been offering this extraordınary collection of Garden Seeds. Each year we have sold thousands of them, and the demand steadily increases from year to year. That it fully satisfies our patrons is proven by the hundreds of testimonials we receive, all of which expresses satisfaction with the results obtained. Having seen similar collections as sent out by other prominent seedsmen, and learning the opinion of hundreds of our patrons, we know that we are justified in saying that our "Family Collection" is

The Largest and Most Complete 50-cent Collection Ever Offered.

OUR OBJECT in making this extraordinary offer is to induce you, -and through you, your friends, - to profit in 1 t, but if it is the means of you trying our Seeds, it will have served its purpose. We are confident you will gladly become a regular patron, in the future.

\begin{tabular}{l} 
Only This \\
Collection. \\
There are \\
many of our \\
patrons who \\
order this col- \\
lection only ; \\
this means \\
that they have \\
tried it and find \\
that it contains \\
enough differ- \\
ent varieties \\
and enoug \\
seeds in each \\
packet to sup- \\
ply the family \\
with fresh veg- \\
etables f rom \\
very earliest \\
date, through \\
the sum er \\
fall and win- \\
ter. \\
\hline
\end{tabular}

\section{Not An Inferior Variety Among Them.}

Beet-Crosby Egyptian. Good size; fine shape; highest quality. Bean-German Black Wax. Stringless; fillest quality; very productive. Bean-Burpee's Stringless. Green pod; positively unsurpassed in quality. Cabbage-Early Winningstadt. Cone shaped, sure header; unsurpassed. Cabbage-Premium Hlat Dutch. Large; sure header. Une of the best. Carrot-Danver's Half Long. Smooth, handsome, very productive. Cauliflower-Favorite. Very early, large heads; most easily grown. Celery-Evan's Triumph. Large, sold, nutty flavor Excellent keeper. Corn-First of All. Very early, inedium size, sweet; very productive. Cucumber-Cool and Crisp. Fine for pickling and slicing; productive. Cucumber-Chicago Pickle. The best variety grown for pickling Egg Plant-New York Spineless, Large, very early and productive. Herbs $-A$ mixture containing several of the most popular kinds.

Lettuce-Grand Rapids. Loose heads, rapıd grower. One of the best. Lettuce-Wonderful. Large headed, crisp, fine flavor. None better. Musk-Melon-Early Hackensack Very early, green flesh, good yielder. Onion-Australian Brown. Miedıum, flattened, unitorm size, mild flavor. Peas-Abundance. Medium early, wrinkled, finest quality. Productive. Pepper-Ruby King. Sweet and mild. Considered the best variety.

Radish-Earliest Wh:te. Good size, oblong, crisp, inıld flavor.

Radish-Chartier. Long, smooth, mild. Planted late is fine for winter. Squash-Mam. Bush Crookneck. Early, large, fine flavor.

Tomato-Imperial. Large, smooth, crimson. Finest for main crop.

Water Melon-Sweet Heart. Large, oval, thin rind, tender, melting.

FLOWER SEEDS-One large packet containing a mixture of ten best easy growing Annuals. This packet will produce a complete Flower Garden. (Varieties can be easily separated when transplanting.)

Are Always
Surprised.
Our patrons
are a lwa y s
both surprised
and delighted
when they re
celve the Fam.
lly collection.
".l never re.
celved so many
Seeds for the
money."
"How c a n
you sell them
so cheap?"
"C a n't find
room to plant
all of them."
These, and
many ot her
similarexpress-
lons are receiv-
ed f rom our
patrons.

\section{All are Positively First-Class, Strictly Eresh, Tested Seeds. Sure to Please.}

We will repeat, to impress you with the fact, that the above seeds are fresh, not old, worthless seeds. The are strictly high grade. Indeed, we could not afford to knowingly send out poor, cheap seeds, as we are depend. ing on their excellent quality to secure your larger orders and entire patronage in the future.

Stop long enough to think just what the above offer means. It is simply this: We are offering you fresh, high grade Seeds, of the best varieties, for only 2 cents per standard packet. You can't buy better Seeds anywhere.

NOTF. These collections are put up early in the season, in a large packet, ready for mailing; therefore we canNOTE, not allow a patron to select any varieties from 1t, at 2 cents per packet, or any changes in the varieties. If other varieties are wanted, order from our General List at 5 cents per packet.

\section{Remember, We Guarantee This Collection to Give Satisfaction.}
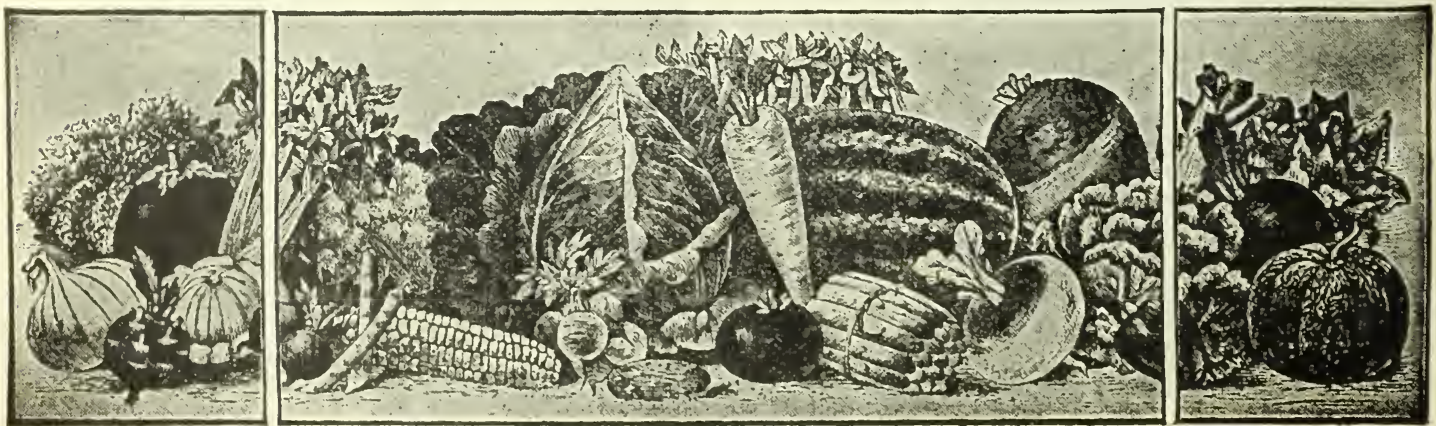


\section{Select Varieties of Seed Potatoes.}

Most Potato growers recognize the advantage of changing Seed Potatoes occasionally. We are offering only a few varieties, such as we can heartily recommend to our patrons. They are true to name, carefully hand-picked and sorted. They are grown under supervision of expert Potato growers, are carefully handled when digging and sorting, and are not bruised or otherwise injured. In quality they are not to be compared to ordinary stock picked up on the market. The Potato crop in this section has been very good this season, and the tubers we have to of fer are smooth and very fine, having been little effected by blight, and ripened thoroughly before digging.

\section{Burpee's Extra Early.}

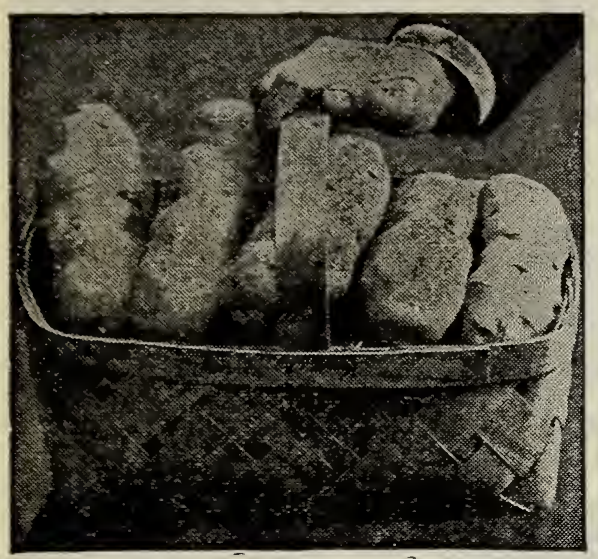

Possesses more Good Qualities than any other Early Potato in existance.

The Earliest Variety of Good Size.

The finest in quality of all the early Potatoes. We have thor. oughly tested this variety for several years, and find it one of the earliest varieties, while it produces tubers of large size. The tub. ers are oblong in form, averaging three to four inches in length, with pure white or very pale brownish skin, few eyes and quite shallow.

The cooking qualities of Burpee's Kxtra Early are all that could be desired, being of the very finest quality. It is the best standard early variety for truckers, as it is not only extra early but also ripens very evenly so that the tops die down and the crop may be dug early so that the land may be planted to other crops. We do not hesitate to recommend this variety to our patrons who may want a variety possessing great merit for earliness and table qualities.

Price, pound 30 cents; 3 pounds for 75 cents, postpaid. By express or freight, peck 70 cents; $1 / 2$ bushel $\$ 1.25$; bushel $\$ 2.00$

"DAINTY-EYE" offered elsewhere is a rery early Potato that bids fair to be a close rival of the above. (See index.)

\section{The Great Cropper, "Koshkonong."}

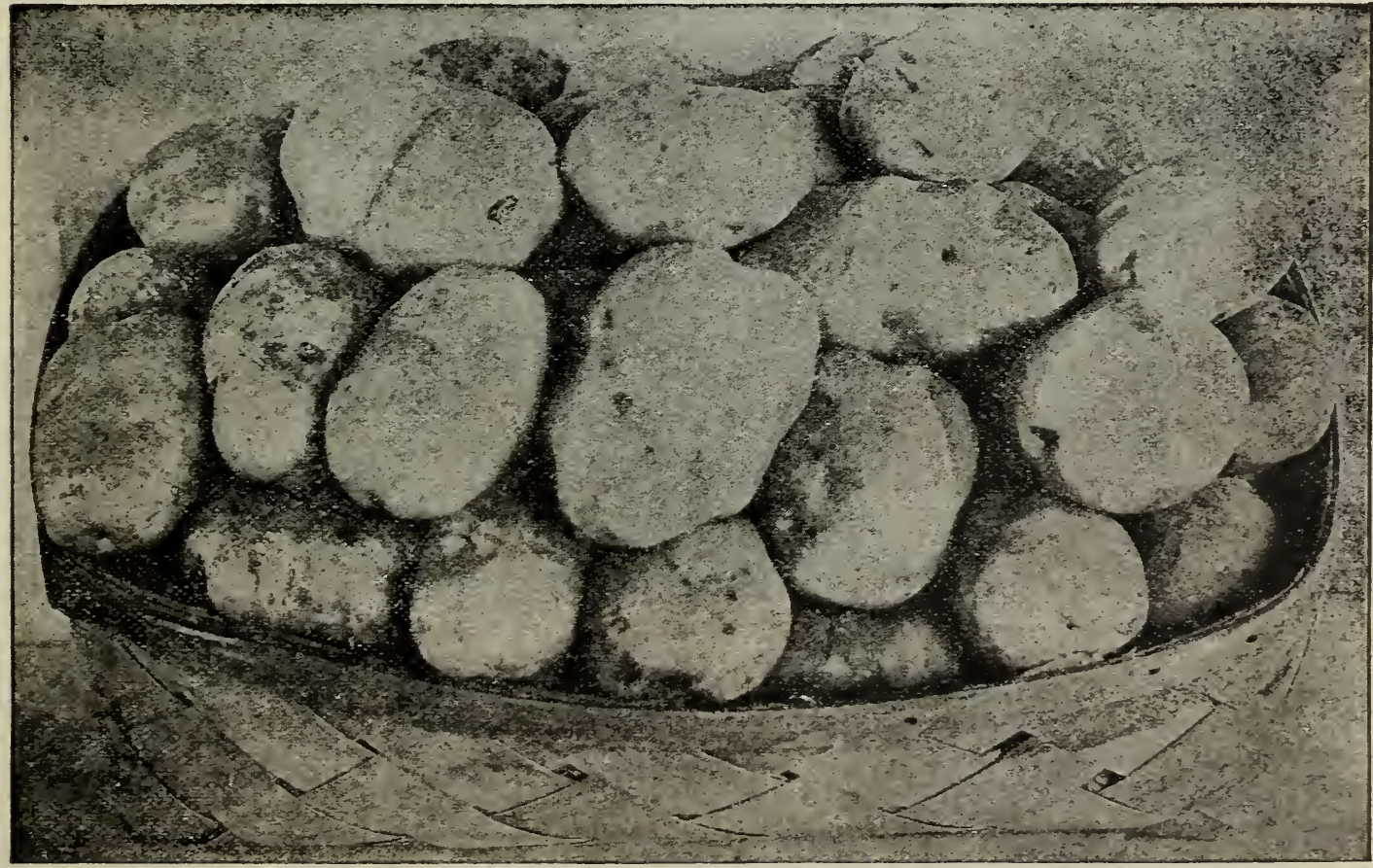

In the Koshkonong we have a general purpose variety of exceptional merit. We know of no other va riety possessing more desirable qualities as an all purpose variety. It is a medium early variety; being a week to ten dayslater than Carmen, and one of the most luxuriant and healthy growers of which we have any knowledge. The Koshkonong is singularly exempt from blight; that disease that so often destroys what would otherwise be a heavy crop. In our experience it maintains a heary, dark green health up to the full maturity of the crop. Its cropping qualities are phenomenal. Its productiveness is largely attributable to the vigorous growth, blight resistance, and uniformly large size of the tubers; none too large and few too small for market and table use.

It is a handsome, pure white Potato, and its crowning merit is its superb cooking quality, cooking white, dry and floury; which, together with its other valuable features, place it in the front rank where real quality is appreciated. 'The tubers aro oval in shape, slightly flattened; the eyes are shallow and near the surface; nearly all toward the blossom end. They are produced on a heavy stem, which is rather deeply indented. Its form, smooth. ness and color makes it attractive in tho market, where they always command a good price. There are few, if any. varieties that possess more points of real merit. We can heartily recommend it to our patrons. Price, $30 \mathrm{cts}$. per pound, postpaid. By express or freight, not prepaid, peck 50 cts; $1 / 2$ bushel 80 cts; bushel $\$ 1.50$; barrel $\$ 3.75$. 


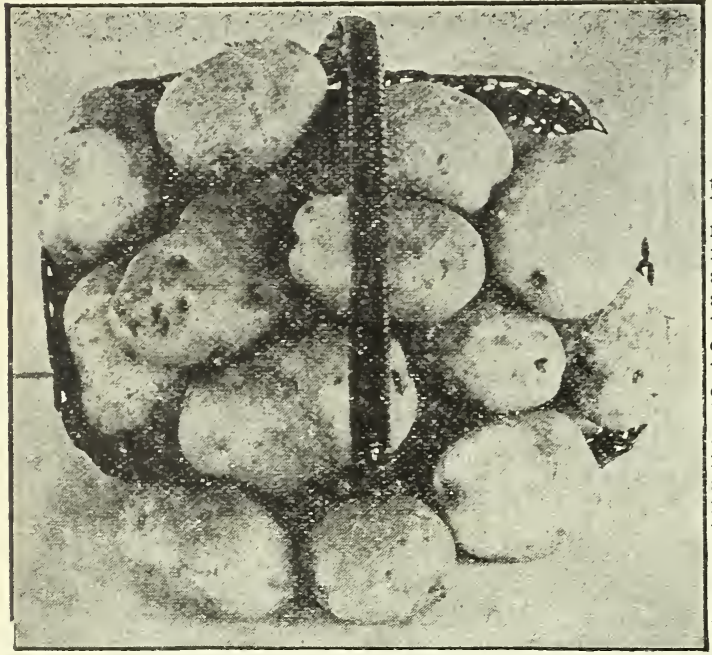

CARMEN NNO. 3 .

\section{Carmen No. 3.}

Noted for its Beauty,

Very Large Size, Uniform Shape, Excellent Table Quality Vigorous Growth, Great Production.

Onc of the most popular of the Carmen group of Po. tatoes. An old varicty having been introduced in IS 95 by the editor of the Rural New Yorker, but it has steadily gained in public favor as a main crop variety. It is a remarkably healthy, vigorous grower of upright habit, and is little effected by drought and blight. The tubers are of large size, rather flat; it has but few eyes and they are shallow; the skin and flesh are white and its cooking qualities are unsurpassed. The tubers set close to the top of the soil, thus giving good yields in heavy, clay soils where many other varieties do almost nothing. It is of perfect form, almost every tuber being of the same size and shape, averaging nearly one pound each in weight in a good season. It is a remarkably handsome, main crop Potato, yielding enormous crops of perfect tubers. Because of it a reliable cropping, it is one of the most profitable varieties known.

Price per pound, 30 cents: 3 pounds for 75 cents. post paid. By express or freight, peck 50 cents; $1 / 2$ bushcl 80 cents; bushel $\$ 160 ;$, barrel $\$ 3.75$.

On page 13 you will find illustration and description of our new Potato, "Knoxemall." Very productive.

\section{Mark Hanna, The Great Main Crop Potato.}

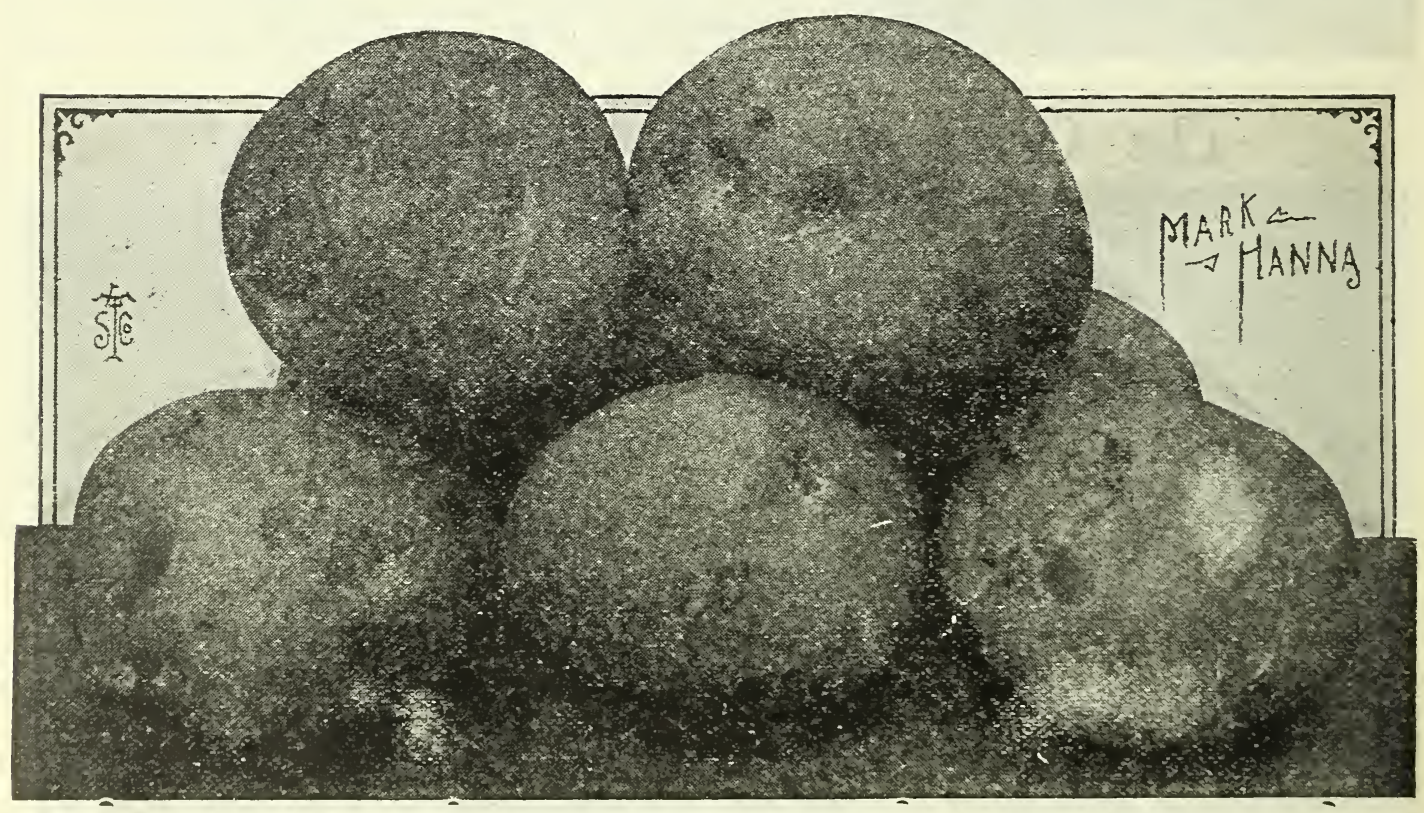

This spleudid variety is remarkable for its thrifty growth and enormons yield of large, handsome, perfect $t n-$ bers. They never grow rough and prongy; always perfectly smcoth and shapely; the delight of all who grow and handle them. The slin is white; flesh white and of excellent quality. In shape they closely resemble the popular Carmen No. 3, with possibly fewer eyes and more uniformly smooth, with few small tubers. The vines are wonderfully vigorous, soon covering and shading the ground, which is a valuable feature. It is certainly one of the most handsome, large, main crop varieties. Very popular where grown for home and market. We can heartily recommend this excellent variety to our patrons. Its cooking qualities are most excellent. Price, pound 30 cents, postpaid. By express or freight, not prepaid, peck 50 cents; $1 / 2$ bushel So cents; bushel $\$ 1.60 ;$ barrel $\$ 3.75$.

\section{WHAT OUR PATRONS SAY ABOUT OUR SEEDS.}

Gentlemen: "This is now the eighth year since I sent $m y$ first order to Templins for seeds. They have always given satisfaction; there has never been any mistakes made; the orders have always been prompt. I am glad to recommend your seeds for therc are nonc better; they are always just what you sar they are." Mrs. Myrtle Cullins, Sonora, Ohio.

Gcntlemen: "The seeds came in good condition, and promptly, as they always do. The size of the packets and the quantity of seed were a surprise. Everything we have ordered from you have been satisfactory." Mrs. J. W. K., Columbus, Ga.
Gentlemen: "For the last ten years I have been getting seeds from Tcmplins, and must say they have always bcen satisfactory in every way; they have never failed to grow. I never had equal success with other seeds. All your dealings have been most honorable and gentlemanly. I remain," Yours, Mrs. Henry Sible, Cortland, Ohio.

Gentlemen: "The two past years we've missed your catalogue, with regret. We first bought seeds from sou in $1 S_{5}$. We have always been pleased with the seeds and plants you sent us." Yours,

Mrs. Tedelia A. Lam, Waterloo, Iowa. 


\section{Selected Summer Flowering Bulbs.}

The Snmmer-flowering Bulbs offered on this page are inexpensive, require bat little care after planting, and preduc s some of the most showy, beautiful and brilliant flowers. 'There are but few flowers that can compare with the Gl.sholi in stateliness and gorgeousness, while the Tuberose excels in fragrance. Our prices are for choice bulbs, postpaid, to any address.

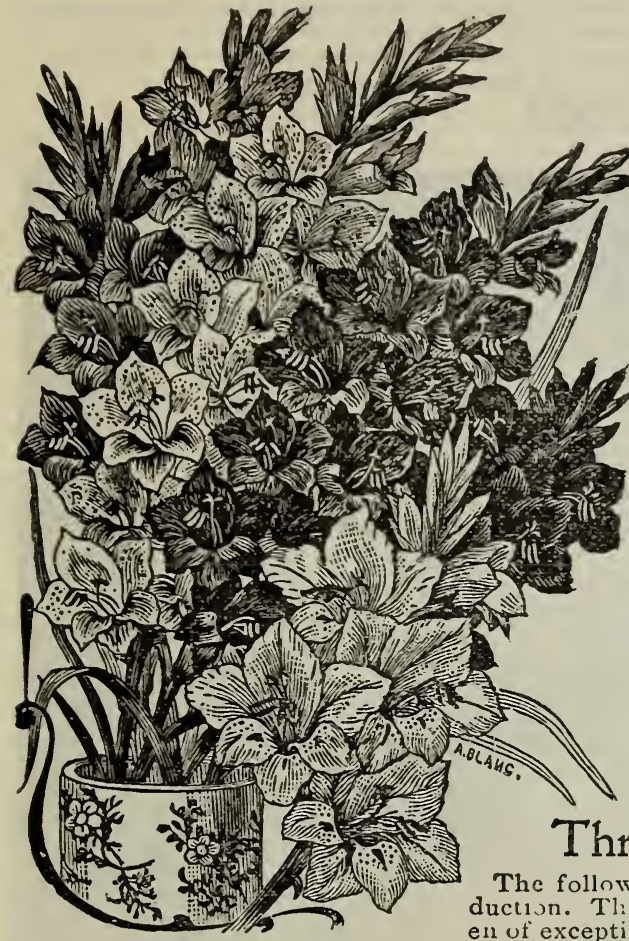

\section{Groff's Hybrid Gladioli.}

Gold Medal and Silver Trophy Strains. The many delicate shades and countless combinations of rare and beautiful colors in this strain far excels all others. Individual flowers are of mammoth size, broad and open, forming truss three or four times as wide as the old type. We offer these in three separate color sections, as follows:

Section A. Containing all scarlet, blood-red, garnet and similar rich, deep shades of red, 11 great variety. A most brilliant mixture. Price, 6 cts. each; 12 for $60 \mathrm{cts}$; Ico for $\$ 4.00$, postpaid

Section B. This selection contains the white, yellow, delicate hades of pink, rose, etc., in great varicty. These are especially valuable for cutting, for vases, etc. Price, 7 cents each; 12 for 5 cents; 100 for $\$ 5.00$, post paicl.

Section C. In this section we include the new blue, heliotrope, ilac, purple, mauve, and other rather unusual shades. They andy all new and distinct shades, therefore very interest cents; 100 for $\$ 6.00$, postpaid.

Gold Medal and Silver Trophy Mixture.

This mixture will contain bulbs of each of the above sections. It will contain a wonderfully wide range of colors; so great a diversity that you take practically no risk of getting any two alike. This is, without doubt, the finest mixtur. possible to obtain, and sure to give complete satisfaction. Price, 7 ccnts each; 12 for 70 cents 100 for $\$ 5.00$, postpaid.

Thrce New Gladioli. duction. Tlicy are very distinct, and have prov-

America. Acknowledged to be the best and most popular Gladioli in the world. Color, bcautiful soft pink, almost the same as Enchantriss Carnation. Unexcelled for cut flower work. Price, 20 cents each; 6 for \$1.co; I2 for \$1.75.

Klondyke. A fine new Gladioli. Color, clear yellow (not orange) being entirely free from markings or trace of other colors except a blotch of vivid crimson-scarlet in the throat. Price, 15 cents each; 6 for 80 cents; I 2 for $\$ 1.50$.

Princeps. A remarkably distinct variety, with immense, wide, open flowers. Color, rich dazzling scarlet, with distinct creamy whitc blotches on lower petals. A strikingly beautiful variety. Price, 20 cents each; 6 for $\$ 1.00$; 12 for $\$ 1.75$.
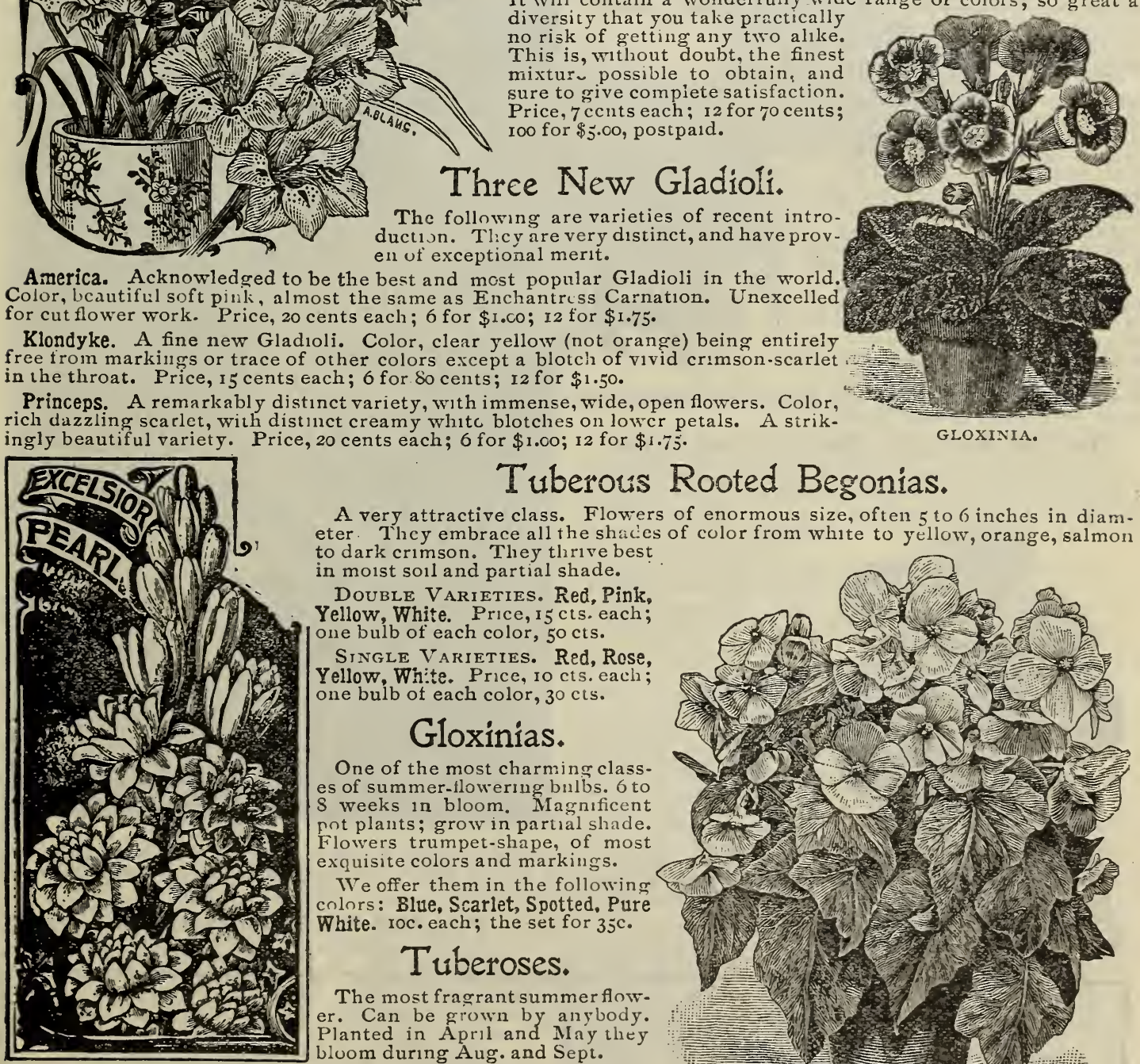

\section{Tuberous Rooted Begonias.}

A very attractive class. Flowers of enormous size, of ten 5 to 6 inches in diam. eter. They embrace all the shaces of color from white to yellow, orange, salmon to dark crimson. They thrive best in moist soll and partial shade.

Double Varieties. Red, Pink, Yellow, White. Price, 5 cts. each; one bulb of each color, $50 \mathrm{cts}$.

Single Varieties. Red, Rose, Yellow, White. Price, io ots, each one bulb of each color, $30 \mathrm{cts}$.

\section{Gloxinias.}

One of the most charming class es of summer-flowering bulbs. 6 to 8 weeks in bloom. Magnıficent nnt plants; grow in partial shade. Flowers trumpet-shape, of most We offer them in the following cnlnrs: Blue, Scarlet, Spotted, Pure White. roc. each; the set for $35 \mathrm{c}$.

\section{Tuberoses.}

The most fragrant summer flow. er. Can be grown by anybody. Planted in April and May they bluom during Aug. and Sept.

Double Pearl. Decidedly the best variety, the flowers being large. waxy-white, whils tlie plants are more dwarf. Desirable as a put plant or for winter forcing. We offer only large blooming bulbs. Price, 8 cents each; 6 for 40 cents; 12 for 70 cents, postpard.

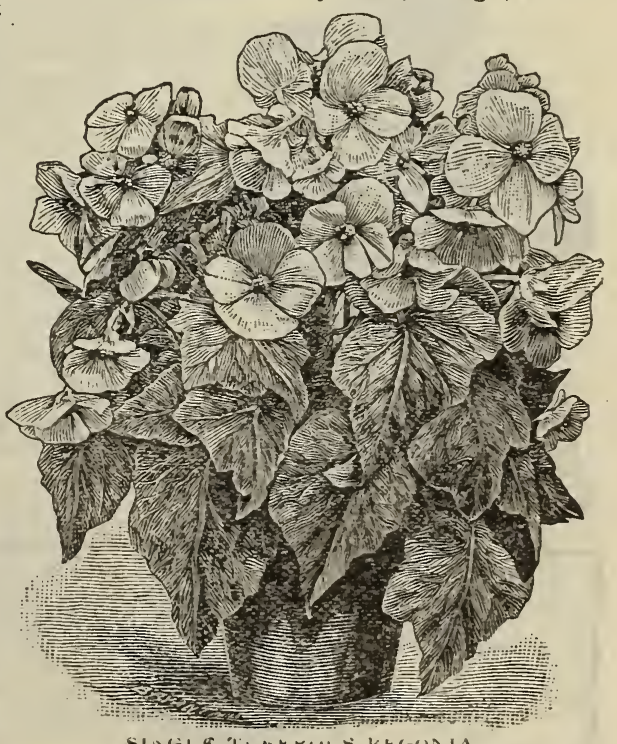




\section{Selected Flower Seeds.}

NEW AND OLD VARIETIES OF MERIT.

On the following fourteen pages will be found our revised list of Selected Flower Seeds. The first nine pages contains a few of our specialties and the best mixtures ever offered. The next five pages will briefly describe and partially illustrate our General List of standard varieties. The last two pages are devoted to a few of our popular collections and Flower Seed Mixtures. There is $n$ ot an inferior variety 11 the list.

\section{The Celebrated "Crego" Aster.}

\section{THE LARGEST AND MOST PERFECT ASTER}

\section{EVER INTRODUCED.}

There has been wonderful improvements in the size and form of Asters, since they were first introduced from China, into Europe, in $173 \mathrm{I}$. They were first single and rather small. while we now have them very double, with enormous flowers.

We believe the highest degree of perfection attained in modern Asters is found in the celebrated "CREGO" which is illustrated herewith. They are truly majestic in habit of growth, and magnificent in the size and style of flowers. They are given enthusiastic praises by all who see them in bloom.

\section{Almost as Large as Chrysanthemums.}

The "Crego" type originated about twelve years ago, from a chance seedling, a cross-fertilization from the best varieties then grown. The present high degree of perfection is the result of the most rigid selection during the intervening years, until today, the type is well fixed. Following is the originators description: "The 'CREGO' Aster is the ner. est approach to a Chrysanthemum of any flower grown. It is unusu. ally large in size, measuring four to five inches in diameter when well grown. The petals are about double the length of those in the older varieties, and are twisted and curled in such a manner as to give the blossoms an exceedingly, beautiful and fluffy appearance.

The plants are of large, luxuriant growth, attaining a height of 24 to 36 inches, producing from 20 to 30 splendid large flowers, on long, stout stems. A well grown plant in full bloom is exceedingly great beauty and substance, they are

\section{The Best Asters For Bouquets and Vases.}

The illustration herewith is an excellent reproduction from a photograph of the White Crego. It shows per: fectly the strikingly beautiful character of the petals and

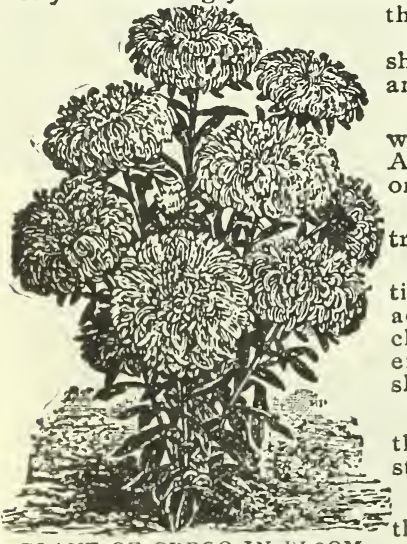
the form of the flowers. The small illustration shows habit of growth and profusion of fiowers. Colors. A t present we can offer the Crego Aster in only three colors, as follows:

Pure White. See illas Shell Pink. This beau. tiful variety is almost exactly the shade of En. chantress Carnation; an excecdingly popular shade at present.

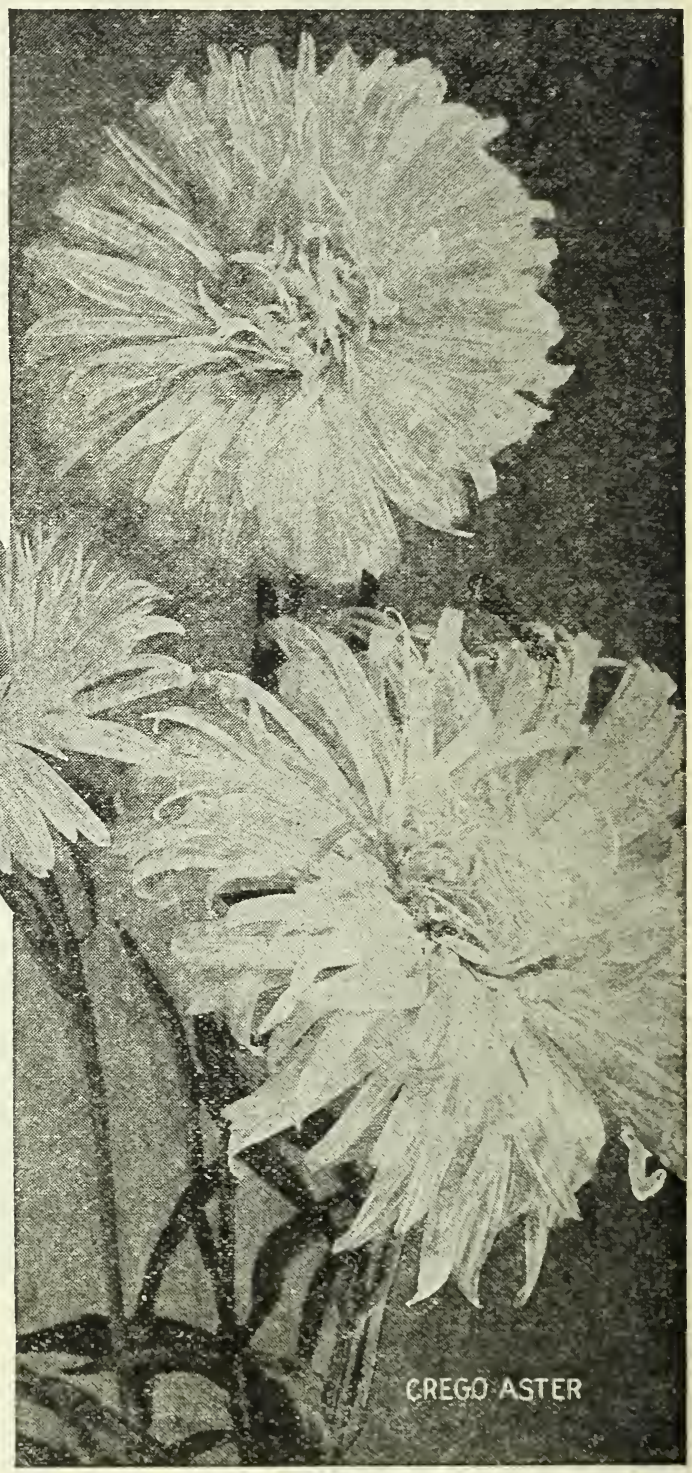

Dark Pink. Several shades darker than the above. This variety, when given the best culture, is a giant among Asters, standing three to four feet high, with stems and flowers fully in proportion.

Price. per packet of roo seeds. White. Shell Pink, Dark Pink, 15 cents each; the PLANT OF CREGO IN IILOOM.

Gentlemen" "The Seeds ordered from you are received, with the additional Flower seeds for which please accept my thanks. As regards the quality of your Seeds, I am very glad to state that 1 have always found everything to be exactly as described in the catalogue. I therefore foel 110 hesitation 11 orderng any new variety which you endorse." I'ours truly. F.mma A. Porter, Medford, Mass.
Gentlemen. "Your Prize Asters were the finest in variety I ever saw: many asked where I got the seed. Your Ideal White Celery is the best I ever grew." Iours, Peter V. Springer.

Gentlemen: "The Seeds ordered from you came promptly, as they always do. The size of the pack. ety was a surprise. Quality of Seeds was excellent." Miss Pauline K., Columbus, Ga. 


\section{Giant Comet Asters. \\ A Strikingly Beautiful Class.}

Truly one of the most handsome of the tall varieties. They win enthusiastic praises from all who grow them. Vheir very large, double flowers are of ten five to six nches across, composed of long curled and twisted petals, gracefully formed into loose, but very double half-globes, closely resembling some of the finest Japanese Chrysanthemuns. The plants are of luxuriant rrowth, attaining a lieight of 15 to $1 \mathrm{~S}$ inches, and producing 20 to 30 strikingly beautiful flowers, on long tems. They are especially fine for cut-flower purposes. We offer four of the most distinct colors, separate; ulso choicest mixed.

Pure White, Light Blue, Dark Blue, Rose. Packet Io cents; 3 packets 25 cents; 6 packets 45 cents.

All Colors Mixed. Including all of the above and many other colors. Packet ro cents; 3 pkts. 25 cts.

\section{Queen of the Market.}

The Queen of Early Asters.

A superb variety of gracefully spreading habit. Val. able for its extreme earliness: coming into bloom fully two weeks before most early sorts. The flowers are perfectly formed, very double, from $2 \frac{1}{2}$ to 3 inches in diameter, the petals being slightly recurved. The plants are of healthy, robust, branching growth, 15 to is inches high, blooming freely for several weeks. Very desirable for cut-flower work. Following are the most distinct colors:

Pure White, Dark Scarlet, Dark Blue, Rose, Packet 10 cents; 3 packets for 25 cents; 6 packets for 45 cents.

A11 Colors Mixed. This mixture will include all of the colors of this class. All unequaled mixture. Pkt. ro cts; 3 pkts. $25 \mathrm{c}$.

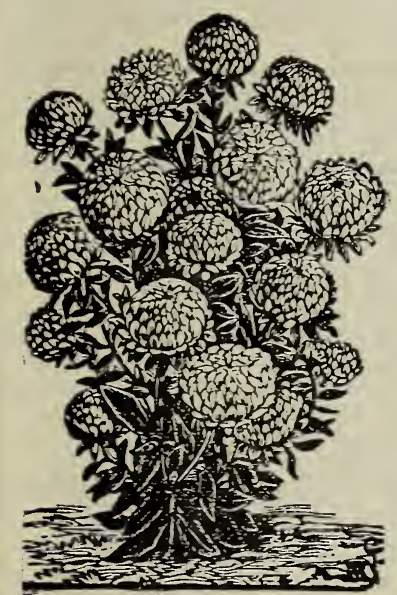

\section{Semple's Branching.} Late Flowering.

This is a grand new strain of

American introduction. They are

superior to any other class of late-flowering branching Asters, and by their use the Aster season is lengthened untul frost. The flowers are large, of en four inches across, very double, of the purest and most beautiful colors. They begin blooming about September ist. Valuable for bouquets and vases, because of long, stout stems. Plants are strong and vigorous, IS to 24 inches high. We offer the most distinct colors, as follows:

Pure White, Bright Pink, Crimson, Lavender. Packet 10 cents each; 3 packets for 25 cents; 6 packets for 45 cents.

All Colors Mixed. Including above and all other colors. Pkt. 10c; 3 for $25 \mathrm{c}$.

\section{Mixed Dwarf and Mixed Tall Asters.}

We have arranged with our growers to furnish us with a superb mixture of sereral of the very best Dwarf Asters; also the best Tall Asters. These mixtures will embrace all of the most distinct colors of each class. You can order either of these mixtures with full confidence that they will give you entire satisfaction. They are very desirable for bouquets, etc.

Dwarf Mixed, pkt. $10 \mathrm{cts}$; 3 for 25 cts. Tall Mixed, pkt. 10 cts; 3 for 25 cts. Each packet of Asters will contain not less than 150 seods.

QUEEN OF THE MAKKET.

(1)

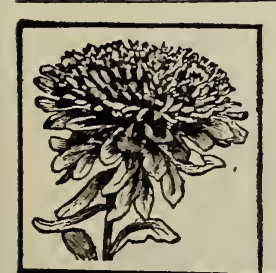

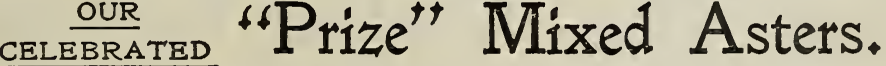

We have for many years offered a superb mixture of Asters under the name "Prize" Mixed Asters. They have given universal satisfaction, and the demand has steadily increased from year to year. In fact, wo do not hesitate to recommend them as the most complete mixture of As-
ters ever offered. We sell many thousand packets every year and have never yet received a single complaint. In the preparation of this fine mixture we procure all the different varieties we can find among different growers and then mix them thoroughly and fill the

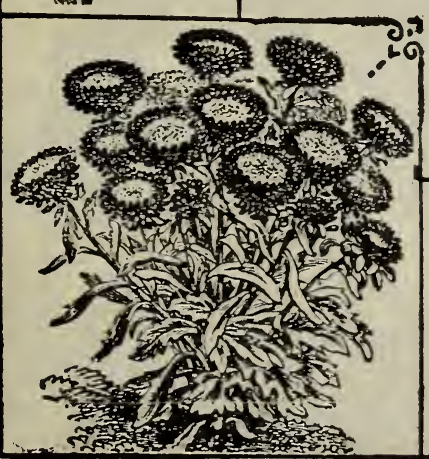
packets from this superb mixture. Each packet will contain seeds of all the choice varieties on this page, and a great many others. A very suitable and desirable present to send to one or more of your lady friends. Packet ro cents, I50 seeds; 3 packets for 25 cents; $1 / 8$ ounce 40 cents; $1 / 4$ ounce $; j$ cents; I ounce $\$ 1.50$.
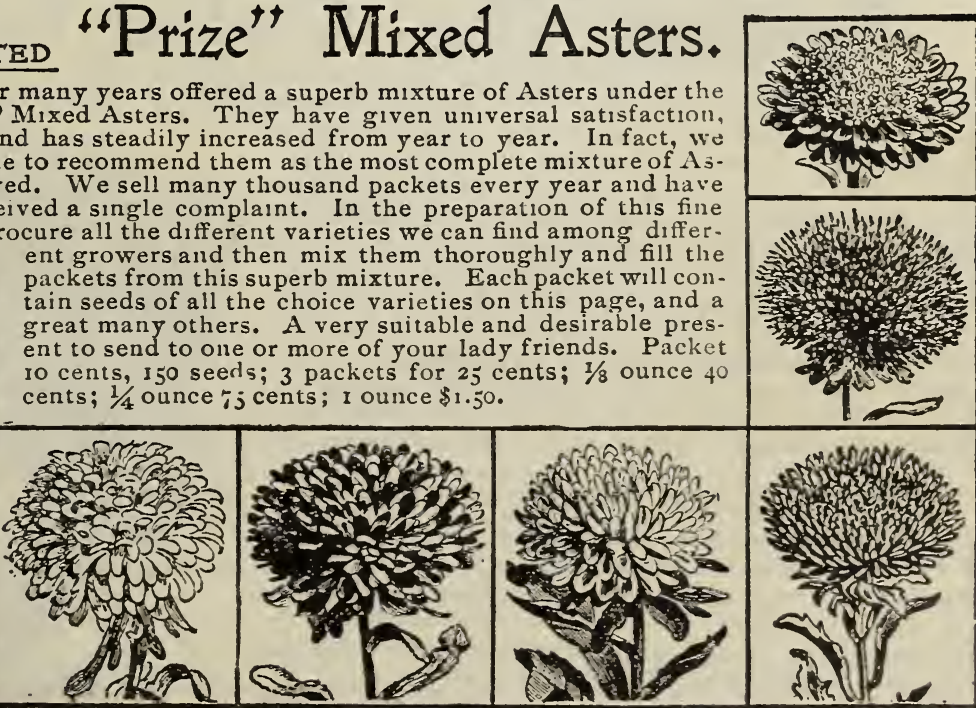


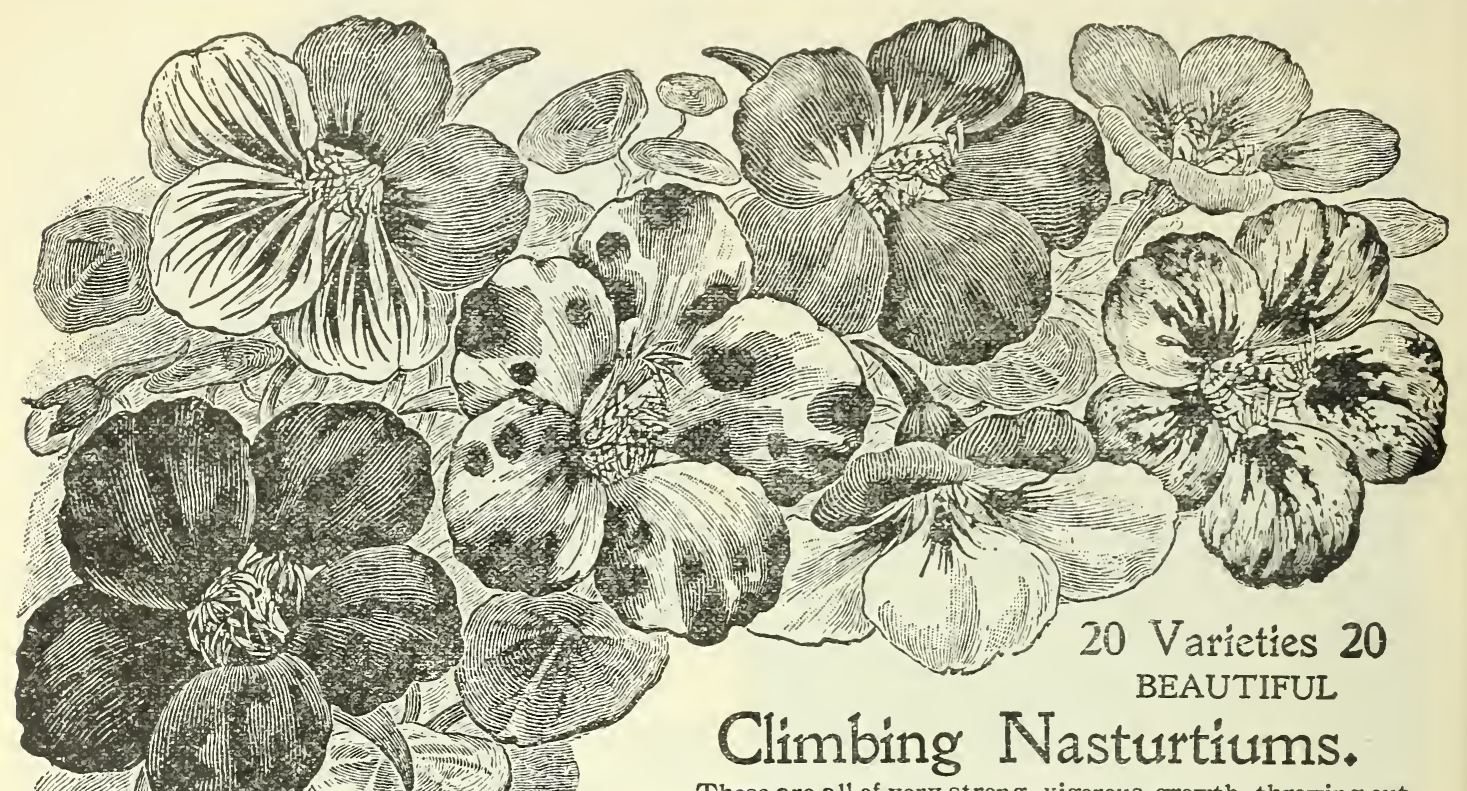

These are all of very strong, vigorous growth, throwing out shoots that can be traint d upon strings or wires, or can be made to climb the ordinary picket fence or nire netting. They are beautiful simply training on level ground. Purchase an ource and plant 2 seeds in each hill with your corn. which will give jou an abundance of beautiful flowers, and you will be surprised with results.

NOTE. Each packet of Nasturtiums will contain 60 seeds: 3 of each of the following ramed varieties. Remember, there is no guesswork about it; positively 3 seeds of each.

Chameleon. Flowers of many colors on same plant. Crimson. Bright glossy crimsun. Vers fine.

Dunnett's Orange. Golden orange, blotched with red. Edwara otto. Flowers light brown, yellow spur. Golden Leaved Scarlet. Derp scarlet flowers. Hemisphericum. Brixht straw with scarlet blotch. Heinemanni. Silky bronze-chocolate. A novel color. King Theodore. Dark crimson: one of the darkest.

Luteum. Clear, light sellow flowers; very attractive. Pearl. Nearest a pproach to cream ever produced.

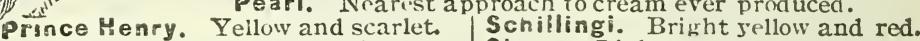
Regelianum. Deep purple violet. Straw. Light straw color. Scarlet. Intensely bright scarlet. Scarl t Striped. Distinctly striped. Scheurianum. Yellow and crimson. Vesuvius. Brilliant fiery rose; fine. Scheurianum Coccineum. Orange. Von Moltike. Peculiar bluish pink.

PRICES:-The above collection, 3 seeds of each, packet $10 \mathrm{cts}: 3$ packets for 25 cents. The above 20 varieties mixed in bulk, packet of 50 seeds for 5 cents: 4 packets for 15 cents: $1 / 4$ pound 40 cents.

\section{Templin's "Ideal" Climbing Nasturtiums.}

The following are varieties of recent introduction; all possessing real merit. They are the best and most beautiful and for real brilliant colors and distinct markings are unsurpassed. We can heartily recomnend them.

Firefly. Distinct: flowers rosy salmon; netals marbled and stri, sed carmine. Showy as a Pansy. Pkt., 50 seeds, 5 cts.

Marguerite. Deep yellow, st riped and blotched rich brown, orange and carmine. Very distinct and beautiful. 50s. $5 \mathrm{c}^{ \pm} \mathrm{s}$.

Mad. Gunther's Hybrids. Unsurpassed in richness and brilliancy. (See cut opposite.) Finest mixed, 50 seeds, 5 cents.

Primrose. Fine primrose-yellow; small dark brown blotch on each petal, which are long and narrow. P'kt., 50 seeds, $5 \mathrm{c}$.

Princess Victoria Louise. Creamy white with orange blotches sometimes edged with red; very beautiful. Plit., 50 seeds, $5 \mathrm{c}$.

Tall Chameleon. Flowers of various colors on same plant: blotched and splashed in varied shades. Pkt., 50 seeds, $5 \mathrm{cts}$.

\section{Ivy-Leaved Nasturtiums.}

Golden Gem. Medium size, golden nrange: ed ges of petals finely fringed and heavily veined. Plit., 25 seeds, 5 cents.

Flamingo. Orange scarlet: unper netals marked with fine brown lines in the ihroat. Packet of 25 seeds, 5 cents.

Fordhook Fancy. Onen, star-like petals: sellow with carmine blotch in each petal. Packet of 25 seids, 5 cents.

Any 5 packets for 20 cts; the 9 packets for 35 cts.

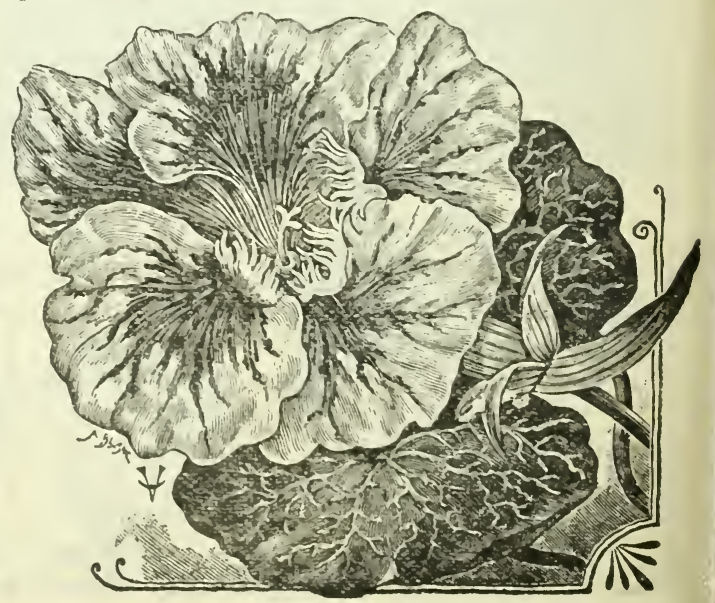




\section{BUSH or DWARF NASTURTIUMS.}

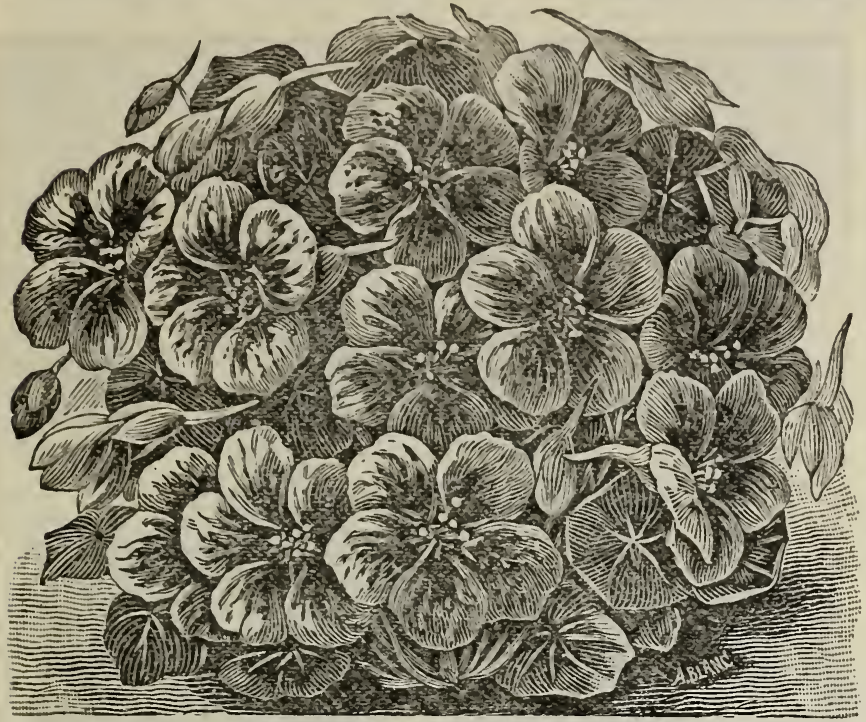

TYPE OF DWARF NASTURTIUMS.

Cloth of Gold. Golden foliage and scarlet finwers.

Crystal Palace Gem. Sulphur-5ellow, spotted carmine.

Coccinewm. Flaming nrange-scarlet.
Empress of India. Dark green foliage, flowers darl scarlet

Golden King. Bright golden Jellow; dark foliage.

King of Tom Thumbs. Intense scarlet flowers.

King Theocore. Deep chocolate crimson; dark foliage. Spoited King. Golden-5ellow; chocolate spotted.
PRICES. 10 cents per pachet containing 60 seeds: 3 of each of the above Choice Varieties. 3 packets for 25 cents.

The 20 varieties mixed in bulk, packet of 50 seeds, 5 cents; ounce 20 cents; $1 / 4$ pound 50 cents; pound $\$ 1.75$. This is the most complete a ssortment of Nasturtiums ever offered.

\section{New Dwarf Nasturtiums.}

These varieties are all of dwarf, compact habit. They are especially valuable for bedding, or borders for beds of taller annuals or along wallis. Blinm profusely all summer; the flowers being as brilliant and varied in colors as the tall varieties.

Aurora. Deep chrome jellow: lower petals blotched and veined with bright carmine. A magnificent sort. 50 seeds, 5 cents. Dwarf Chameleon. Wonderful in variety and richness of colors; blotched and reined. Unexcelled. Plit., 50 seeds, 5 cents. Golden Queen. Brilliant golden Jellow; blooms profusely. Unequaled for ribbon border or massing in beds, 50 seeds, $5 \mathrm{crs}$.

Lady Bird. New and distinct. Golden Jellow, each petal barred and veined bright ruby crimson. Pkt., 50 seeds, 5 cents.

Prince Henry. New and norel. Yellow, spotted and marbled with brilliant scarlet. Vers striking. Pkt., 50 seeds, 5 cts.

Tom Pouce. Bright jellow, vivid scarlet and glowing orange. Fine trailer for baskets and vases. Pkt., 50 seeds, 5 cents.

Vesuvius. True "Tom Thum." Brilliant salmon pink. An extremely bright and show $s$ variet $J$. Plit., 50 seeds, 5 cts. Ans 4 packets 15 cents; the 7 pacliets for 25 cents.

\section{MINA LOBATA.}

A vigorous climbing annual from Mexico. Buds at first are vivid red, but turn to oranse-yellow as they open, and finally creamy white. Grows 18 to 20 inches high. A free bloomer. Start seeds earls in the house and bed out in June. Packet of 15 seeds, 5 cents.

\section{NICOTIANA.}

Sanderae. This grand hrbrid variet $y$ is the most strikingly beautiful plant of recent introduction. It forms much-branched, bushy plants 2 feet high, literally ablaze, from base to summit, with rich, glowing, rosy-carmine flowers. Blooms all summer. Mixed H J brids, 300 s., 5 cts.

Tuberose-flowered. Grows about 2 feet high. Flowers pure white, tube-like; open about 6 o'clock and emit a powerful and pleasant-frasrance during the evening and night. A good border plant. Pht., 500 serds, 5 cents.
Twenty Choice Named Varieties.

Well known plants common in every garden. Thrive in any warm, sunuy, fairly moist place. Easily grow a from seed, which should be sown where they are to bloom. For early effects, the seeds may be started indoors in pots or boxes, and transplanted. Require but lit le care. Nothin\& in a florists catalogue will give greater satisfaction.

The following collection of Nasturtiums will furuinh a nuch greater variet $y$ of forms and markings and more brilliant colors than the common varieties as generally sold. We have onls space to give each a very brief description.

Each packet will contain 3 of each of the following named varieties. There is no guess work about it; positively 3 of each.

Aurora. Chrome yellow, veined carmine. Beauty. Golden orange-flamed scarlet. Brilliant Yellow. Most brilliant clear yellow. Bronze Colored. Of a burnished bronze color. Cattell's Crimson. Rich crimson-scarlet. Chameleon. Crimson, brown and yellow. ady Bird. Goiden-yellow, barred with rubs crimson. earl. Very light straiv color; fine for contrast. rince Henry. New. Yellow, marbled bright scarlet. Ruby King. Dark foliage; rubs-rose flowers. egelianum. Deep purpli-h crimson: one of the darkest. poited King. Golden-sellow; chocolate spotted.

of the above Choice Varieties. 3 packets for 25 cents.
ounce 20 cents; $1 / 4$ pound 50 cents; pound $\$ 1.75$. This is

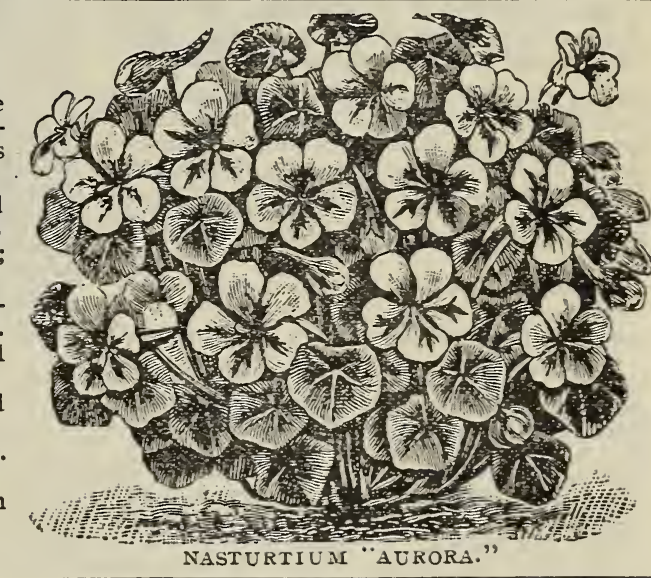

NASTURTIU MTITERT

Beard-Tongue. Beautiful and attractive herbaceous plants, native of Western U. S. Flowers produced on long spikes, somewhat like perennial Phlox in habit of growth. Colors, white, pink, scarlet, blue, etc., beautifully spotted and marked. Very brilliant and showy. Bloom the first season from seed, if sown early. Superb mixture of the choicest varieties. Packet of 200 seeds, 5 cents.

\section{PENINISETUM LONGISTYLUM.}

Purple Feather Grass. One of the most ornamental decorative grasses ever introduced. As useful and beautiful for hall or table adornment as a Palm. The graceful, narrow, curving leaves a re overtopped bs elegant purple, eathery plumes a font long. Most beautiful and graceful plant for pot culture: alwass a feature of attraction. Sow seeds early in March. Pkt., 100 seeds, 5 cents. 


\section{Templin's "International" Giant Pansies.}

\section{Unequaled in Variety.} Beauty and

Remarkable Blending of Colors.

This is a Collection we have offered for many years. It is now recognized, among our patrons and all others who see them, as being unequaled in the innumerable varieties, size of flowers, wonderful delicacy of shadings and blending of colors. They embrace every color and shade known among Pansies; marvelous in boldness, distinctness, pencilings, blotches and gorgeous colorings. We receive many letters from our patrons praising their superior beauty, size and other merits of our "International" Pansies.

There is probably more money spent annually for Pansies than any other one class of flowers, and there is nothing more satisfactory than a bed of really choice Pansies; but on the other hand, there is nothing more disappointing than a poor strain. Realizing these facts, and desiring to furnish our patrons only the best, we have by great effort and expense, secured what we know to be

\section{Strictly High Grade Pansies}

From
The Worlds Greatest Pansy Specialists.

We have named the collection our "International" Giant Flowered Pansies, because of its makeup; we have purchased Giant Flowered varieties from each of the greatest Pansy specialists in America, England, Germany and France. From each grower we have selected the most distinct varieties of recent introduction; and from some of them the Highest Grade Mixtures.

This Collection of 36 Varieties, the names of which are given below, is far superior to what it was years ago when first offered.

Adonis. Light blue, white centre, darker eye Aurea Pura. (Goldelis, Yellow Gem.) Auriculeaflora. Mahogany color. Fine. Azure Blue. The best deep sky-blue known. Baron de Rothschild. Dark brown spots. Bridesmaid. White, reflecting beautiful rose Bronze Color. Richest shades of bronze Cardinal. Glowing scarlet. A magnificent color.

Cassier's Hortense Red. One of the most

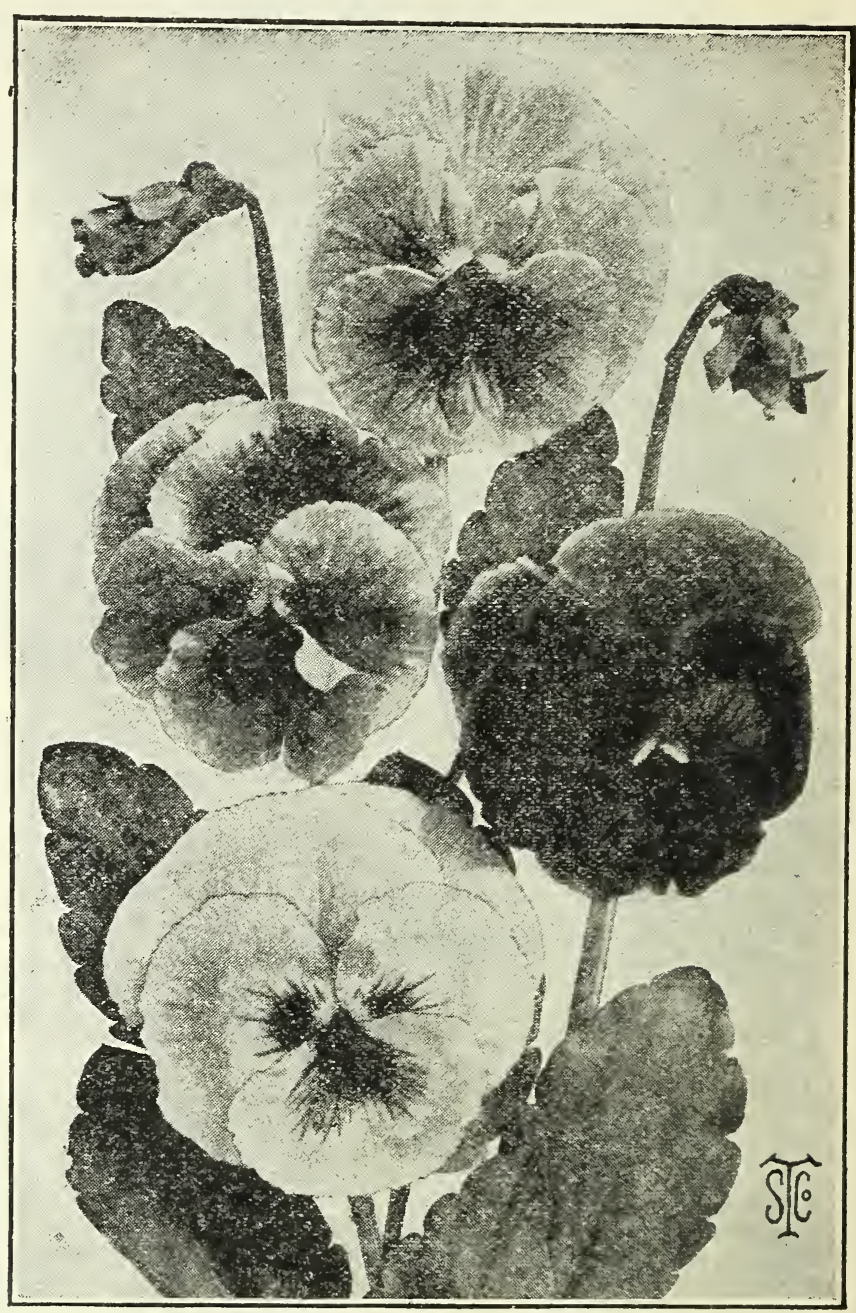
beautiful reds.

Cassier's 3 and 5 Spot. Exceedingly well defined spots. Dark Blue. Deepest dark blue. The very finest.

Emperor William. Ultramarine blue, with purple eye.

Fire King. Fiery-red with golden yellow. The best red. Freya. Beautiful shades; petals silver edged.

Gloriosa Perfecta. (Quadricolor.) A very fine strain. Golden Queen. Purest yellow; exceedingly fine. King of the Blacks. Splendid glossy black. Very finest. Light Blue. Sky-blue. One of the most beautiful.

Lord Beaconsfield. Purplish violet, with white margin. Meteor. New. Fiery brown-red. Very beautiful. Prince Bismarch. Golden bronze, beautifully bronzed. Purple Mantle. Fiery purple. A very showy variety. Purple Mantle. Fiery purple. A very showy variety. Yellow. (Black-eyed Trimardeau.) A grand va riety. There never was a better Collection of High Grade Giant Flowered Pansies offered at any price.

Price of "International" Mixture.

We will send a packet of 200 seeds, containing an equal mixture of the above thirty-six varieties, for 15 cents; 2 packets 25 cents; $1 / 8$ ounce 75 cents; $1 / 40 z . \$ 1,25 ; 0 z . \$ 4.00$.
Rosy Lilac. Beautiful blending of lilac and rose. Ruby king. Large ruby-red; one of the finest. Snowflake. (Candidissima.) Purest satiny white. Striped and Mottled. Large flowered; exceedingly fine. Trimardeau and Cassier's. Grand mixture Giant sorts. Trimardeau Five Blotched. Exceedingly large and fine. Victoria. Splendid splashes of wine-red. Very fine. Violet Blue. A splendid shade of blue. Very large. White. (Purple-eyed Trimardeau.) A very fine variety. White Marbled. Fine white, splotched and marbled. Woodbury's Finest Striped. Superior striped varieties.

\section{Prices In Separate Colors.}

We will send a packet containing $y_{5}$ o seeds of any one ( $f$ the above choice strains, postpaid, for only ro cents; 3 separate packets, 25 cents; an 57 for 50 cents.

Pretty Pansy Booklet Free. With every wrder for our "Intermational" Giant Pansy Mixture, Booklet on Pansies. It gives a brief history of Pansies, from the time they were first brought into public favor to the present. It also gives very practical cultural directions that will enable anyone to succeed with Pansies.

Price of booklet locents; but we send it free with the collection.

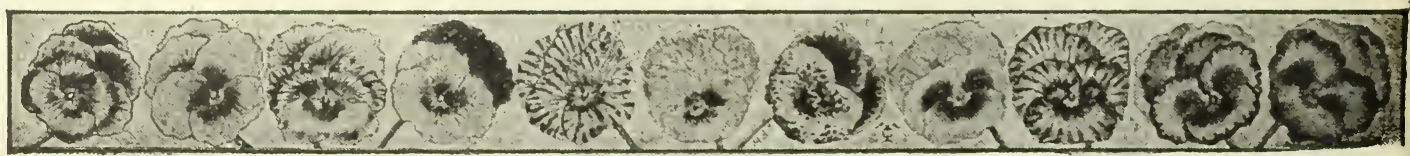




\section{Templins" "Elite" Giant Flowered Pansies.}

Our patrons will sreatly appreciate the following list of varieties. They are positively the best Giant Flowered Pansics known. They represent the highest degree of perfection attained by Fansy Specialists in America, Germany, England and France. We guarantee them to give satisfaction. Each packet contains 150 seeds.

Benary's Non Plus Ultra. Most noted English strain. Extra large; celebrated for beautiful blending of colors. Fine mixture. Price 10c.

Bugnot's Superb Blotched. A celebrated French strain, noted for extra large size, rich and varied colors. Shades of red, brown and bronze seldom found in other strains. The finest blotched. 10c.

Cassier's Superb Golden Yellow. A magnificent strain, containing the richest shades of sellow: extra large, with beautifully frilled petals: 5-blotched. Very distinct. Price 10 cents.

Cassier's Giant Bridesmaid. Giant flowers of splendid form, Ros5white, rivaling in delicacy the apple blossom; rich dark purple blotch in centre of each petal. Very distinct. Price 10 cents.

Giant Peacock Pansy. Strikingly beautiful. Very large, rich ultramarine blue, with narrow white border. Centre purplish crimson and rich rosal purple. Resembles a peacock's feather. Price 10 ccnts.

Large Flowered Striped Parisian. Distinct, and of great merit. Very large gorgeous in colors, being blotched, spotted, marbled, striped and veined; the colors are beautifully blended. 10 cents.

New Giant Pretiosa. Magnificent flowers of very large size and finest form. Color, carmine purple, with bright violet blotch in each petal; beautifully margined white. Sure to give satisfaction. 10c.

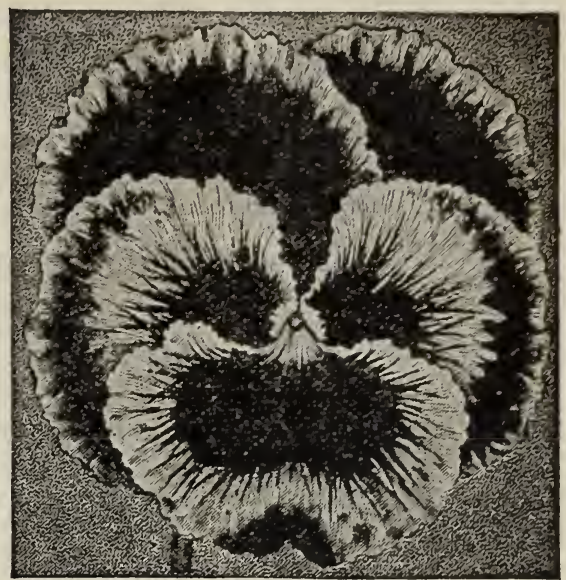

MAD. PERRET.

Madam Perret. Very largest rounded form and most Psyche. One of the finest strains. Very large, with beautiful coloring. Lower petal canary-5ellow, or rosy-pink violet blotch in each petal, relieved by a broad margin of blotched and veined purple-rose and carmine. 10 cents.

Masterpiece. A new strain of rare beauty. Differs chiefly in form of flowers, being conspicuously ruffled and curled. Possess rare tints. (See cut below.) 10c.

Odier's Giant Five-Spotted. One of the most beautiful strains. Largest size, splendid form and brilliart shades, each petal having a well defined blotch in centre. $10 \mathrm{c}$.

Orchid Flowered. The upper petals, instead of being broad and round, stand upright and slightly resemble Orchid flowers. Colors the finest known to Pansies. 10c. white. Edges of petals elegantly waved. 10 cents.

Sach's Elite Mixture. A magnificent German strain of largest size and perfect form. A mixture of the most distinct colors and sharply defined markings. 10 cents.

Snowflake. A giant variety. Pure satiny-white with small yellow eye: sometimes tinged with delicate pink. Truly a magnificent Pansy. The best white. 10c.

Trimardeau's King of the Blacks. Decidedly the iargest and finest strain of Black Pansies. Flowers roal-black, having only a small yellow eye. 10 cents.

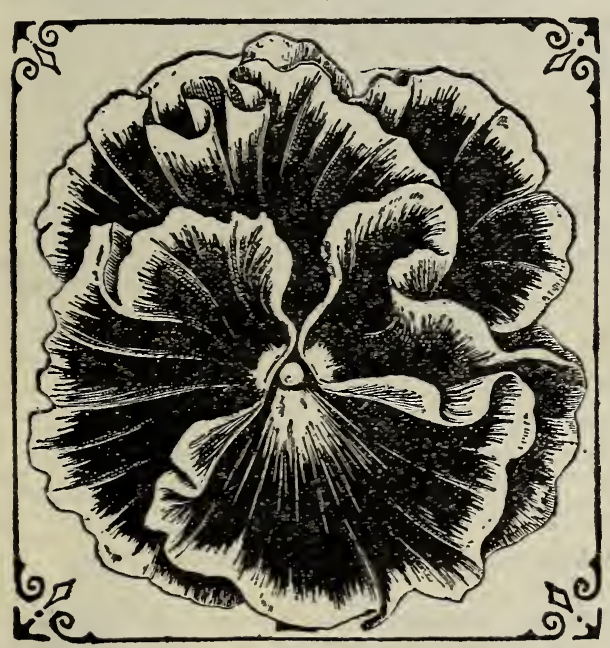

Trimardeau's Fire King, A grand French strain. Largest size, . 7 excellent form. Upper petals bright reddish-brown; really a fier 19 shade Lower petals each have a large blotch of magenta, 10c.

\section{Templins' Phenomenal Pansies.}

of recent years the improvement in size, form, and blending of colors in Pansies has been phenomenal. We call them "Phe nomenal" because of their remarkable and unusual beauty.

Bugnot's Exhibition. The most valuable strain known. The most varied in color and markings. Perfect in form. 10c. pkt. 150 seeds.

Cassier's Giant Blotched. A new type of great merit. Very large. Flowers blotched, spotted, marbled, veined, striped. $10 \mathrm{c} .150$ seeds. Giant Golden Queen. A magnificent variety. Clear yellow, with dark pencilings in centre. Largest and finest yellow. 10c. 150 seeds. Giant Indigo Blue. A magnificent giant-flowered strain. Enormous size, fine form; indigo blue-a ra re color. 10c. per 150 seeds,

Mammoth Parisian. A grand variety. Usually a large blotch on each petal. They are gorgeous, embracing all colors known to Pansies. Mammoth in size. 10c. packet of 150 seeds.

Odier's White Five-Spotted. Strikingly beautiful. Largest size, pure white. with large rich velvety blotch in the centre of each petal. The most showy strain known. 10 cents packet 150 seeds.

Woodbury's Giant White. A remarkably large and fine strain of excellent form and fine substance. $10 \mathrm{cts}$. per packet of 150 seeds. Price-packet of 150 seods, 10 cents; 3 packets for 25 cents; any 7 packets for 50 cents.

\section{Templins' "Excelsior" Mixed Pansies.}

We have, for a number of jears, offered this splendid mixture, and it has become very popular. IVe sell thousands of packets each year and never receive any complaints. It is a very complete mixture of choice named varieties. If you want a fine mixture of Pan. sies, at the lowest price, you will make no mistake by ordering this collection. Each packet is filled from a mixture of the following 24 splendid named and dis. tinct varieties.

Albo Marginata. Silver-ed ged. Atropurpurea. Purplish violet. Black, with golden bronze lustre. Black-Blue. Very dark blue. Brown-Red. Beautiful shades. Candidissima. Purest white. Cliveden Purple. Finest shades.

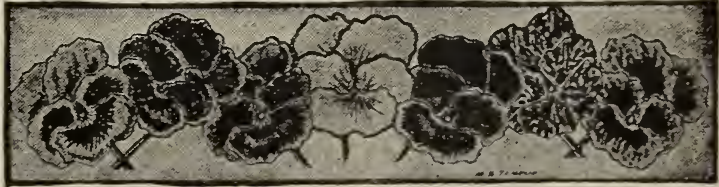

Prico-Pkto, 150 seods, 5c.; 5 pkts, 20c.; 1.8 ounce 25 c.: 1.4 ounce 40c.: 1 ounce \$1.25.

Coquette de Poissy. Rosy blue Emperor Frederick. Purple and orange. Rosy Lilac. Splendid colors Gloriosa Perfecta. (Quadricolor.) Fina Gold Margined. Very fine.

Mahogany Color. Finest shades. Nigra. (Dr. Faust.) Coal-black. Pelargoniflora. Very pretty shade Striata Perfecta. Fine striped. Violet. Beautifully bordered white. Wallfiower. Very effective. White, with dark eye. Yellow, with dark eye

Yellow Gem. Finest yellow. 


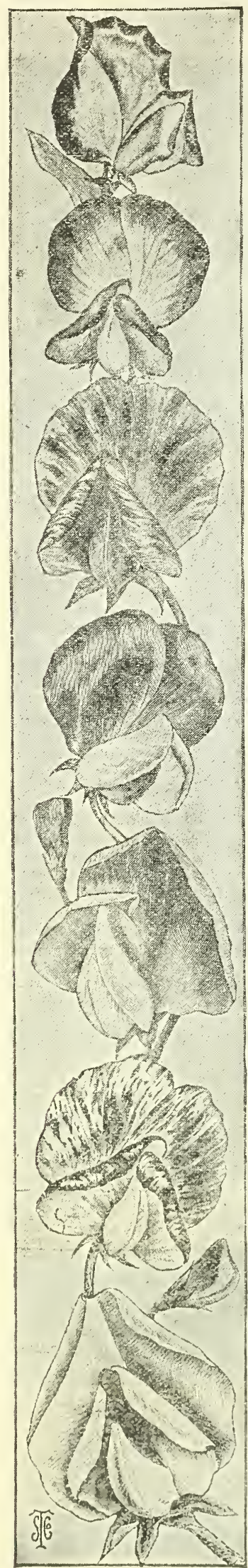

\section{Templin's}

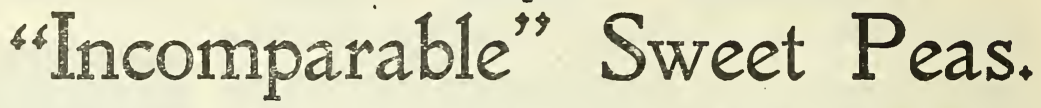

A Superb Mixture Containing 100 Choice Named Varieties.

For the last ten years we have been offermn this splendid mixture. Of course, there has been some changes in the varieties it contains. Every season we have our grower in California revise the list for us, to keep it strictly up-to-date. As new are discarded and the new added. Thus, we have brought the collection up to the highest standard; to a degree of perfection that makes it literally "Incomparable."

You will find many of the recent Novelties in this list.

Admiration-A delicate rosy-lavender. Agres Echford-Delicate shace of pink. America-Crimson-scarlet, striped. Arple Blossom-Delicate shade of purk. Aurora-Orange-rose, striped on wlittc. Biack Michael-Pure maroon. I Large size. Blarche Burpee-Iarge, pure white. Blancke Ferry-Carmine-rose, tinered pink Black Knigl:t-Finest deep maroon.

Boiton's Pink-Salmon-pink, veined rose. Beacon-Creamy-white or light rosc. Cartain of Blues-Clear purple, tinged blue Captivation-Light purple-magenta.

Coccirea-A beautiful cherry-red.

Cocuctie-Primrose, shaded pale ycllow. Coirtess of La'rom-Lovely rosy-pink. Countess Carcoan-Fine reddish-purple. Countess of Radrof-Lovely paled lilac. Dairty-Pure white, ec'sred with pink. Duke of sutherlard-Violet and purple. Duke of Westminster-Purple, tinccd violet Dorothy Eckford-One of the best whites. Dorothy Tennant-Fine rosy-purple. Dora Brear'more-Buff and primrose. David R. Williamscn-Elue, tinted purple. Earliest of All-A lovely blush pink. E.J. Castle-Bright rosy-crimson. Emily Ecliford-Rosy purple ard lilac. Extra Early Blanche Fery-Lovely pink. Earliest Sunbeam-leautilul creamy. white Emily Henderson-Early, large, pure wh Earl Crcmer-Lovel y claret-magenta. Flora Norton-Bright blue, tinged purple. Firefly - Orie of the brightest reds.

Frank Dolby-P1nk1sh mauve and lavender Gorgeous-Brilliant orange-salmon.

Gladys Unwin-Clear bright, light pınk. Golden Rose-Primrose, tipped lipht pink. Mon. Mrs. E. Kenycn-I.1.ht primiose.

Hon. F. Bowverie-Deepest rich pink.

Henry Eclford-The best orange ycllow. Horace Wright-splendid violet-maroon. Melen Pierce-White, mottled brisht blue. geanie Gordon-Deep rose on primirose. Jessie Cuthbertson-Primrose, striped. Juanita-White, striped with lavercer. Janet Scott-Bright pink, tıpped butí
Joho Ingram-liosy carmine, dark ve
Katherine Tracy-Beautiful soft pink. King Edward VII-The best dark red. Lady Mary Currie-Fine crimson-orange. Lady Nina Balfour-Lavender and mauve. Lady Grisel Hamilton-Mauve and lavender Lcrd Roseberry-Iright magenta-rose. Loit:e Eckford-White, shaded lavender. Lovely-The most beautiful soft pink. Lottie Hutchins-Primrose, shaded pink. Lora Nelson-Indigo blue and violet. Ma:d of honor-White, shaded lovely blue. Marchioness Cholmonci!ey-Buff and cream Mars-A very fine crimson-scarlet.

Miss Willmott-The finest orange-pınk.

Modesty-Une of the most delicate pinks. Mont Blanc-Dwarf. Purest white.

Mirs. Dugdale-A beautiful deep rose.

Mrs. Geo. Higginson. Jr. - I r ght lavender.

Mrs. Jos. Chamberlain-White, striped rose

Mrs. Walter Wright-Fine rosy-purple.

Mrs. Co!lier-Yrimrose, tinged yellow. Mrs. Alfred Watkins-Pink, shaded buff. Navy Blue-The darkest indigo blue.

Nora Uawin-Very large, pure white. New Countess-Large, lovely clear pink. Othello-Dark maroon, al nost black. Phenomenal. - White, edged with lilac. Prima Donna-Very pretty soft pink.

Prince Ed. of York--Scarlet and rose.

Prince of Wales-Deautiful crimson-rose.

Phyllis Unwin-Magenta-rose and carmine Quecn Victoria-Fine yellowish primrose. Oueen of Spain-Lovely suft buff pink.

Queen Alexandra-Fine bright scarlet. Ramona-White, splashed with pink. Royal Rose-Very tine deep rosy-pink. Romolo Piazzani-Rosy-purple and lilac. Sadie Burrce-Large size, pure white.

Salopian-The tinest deep crimson-scarlet Senator-White, striped maroon andincligo Shahzada-Decp marucls; almost black. Stella Morse-liff -pink cn cream.

Sue Eail-Kosy-buff auc! cream.

Shasta-Very larie, purest white.

Sybil Eckford-light salmon aud buff. Scarlet Gem-The nearest a true scarlet. Unique-White, striped with light blue. Verus-A beautiful soft buff-pink.

White Wonder-Large, pure white, double. Zoe-Lovely lavender and light blue.

How we prepare our "Incomparable" Mixture of Sweet Peas.

We have a large case or cabinet, which has 100 separate small compartments. We have these numbered con ecutive$1 y$, from I to 1 co. When the $100 \mathrm{Named}$ Varieties are received we number them the same way, filling each compart. ment with the proper number. From these compartments the seeds are taken, one at a time, then placed in the packet. You may conclude this is very tedious work, but our lady employes soon become very expert. Our only reason for going to so much trouble is that our patrons may have

\section{The Best Collection of Sweet Peas Ever Offered.}

Price The "Incomparable" Mixture, 10 cents per packet of 100 seeds-one seed of cach variety: 3 packets for 25 cents; 7 pkts. for 50 ceuts.

"How to Grow Sweet Peas."

Space will not permit giving caltural directions in our cata. lorne. We have, at consider able expense, prepared an at tractive little folder, giving the history of Sweet Peas and their culture. A copy will be sent free with each order for the "Yncomparable" Mixture of Swect Pess.

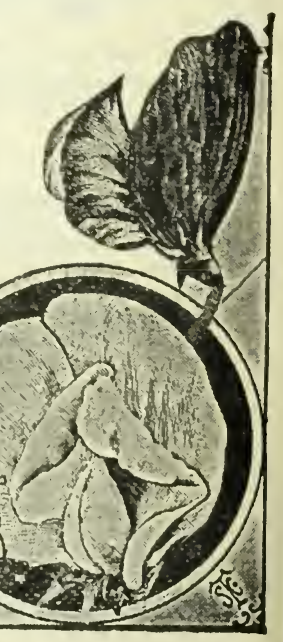




\section{Fifteen High Grade Sweet Peas.}

Following we give brief descriptions of fifteen of the best new and standard varie. ties. They embrace the widest possible range of colors. They are all strictly high grade; such as any professional grower would appreciate.

BLACK KNIGHT. Deep maroon, veirsalmost black: wings shaded brownish-purple. Iarge size, open form. One ot the darkest varieties. Pkt. $10 \mathrm{cts}$; oz. $20 \mathrm{cts}$. COUNTESS SPENCER. Bright clear pink, deeper at the edges. Margins of petals wavy. In size, form and coloring it is exqisite. Pkt. io cts; ounce $25 \mathrm{cts}$.

DOROTHY ECKFORD. The grandest pure white. Very robust in growth; a proprotuse bloomer. Flowers extra large, borme three on a stem. Pkt. 10c; oz. 20c.

EMILY HENDERSON. Large, open form, pure white. Petals are heavier than most other whites, hence has great endurance. One of the most popular. Pkt. 10c; oz. 20c.

HELEN LEWIS. Standard crimson-orange: wings orange-rose: open form with wav $y$ edges. Truly of gigantic size. Decidedly the best of its color. Pkt.10c; 0z. 20c. RON. MRS. E. KENYON. Beautiful primrose. Flowers of enormous size. A vigorous gruwer and free bloomer. The most popular of its color. Pkt. 10c; oz. 20c.

LADY GRISEL HAMILTON. Standard lıght, wings azure blıe: very light and dainty. Of the best hooded form and extra large. Packet 10 cents; ounce 20 cents.

KING EDWARD VII. Bright crimson-scarlet. The magnificent large flowers are of fine form. One of the brightest varieties known. Pkt. 10cts; oz. $20 \mathrm{cts}$.

MRS. WILLMOTT. Standard rich orange pink, veins of deeper color; wings rose with strong tint of orange. Very large. The best of its color. Pkt. IOc; Oz. I5c. MRS. GEO. HIGGINSON, JR. Light lavender and nearly free from any tint of mauve; medium size. The clearest and most delicate blue we have. Pkt. 10c; oz. 20c.

MRS. WALTER WRIGHT. Beautiful rosy purple, changing to bluish purple; very large size; hooded form. Packet Io cents; ounce 20 cents.

NAVY BLUE. Standard indigo and violet: wings indigo, changing to navy and bright blue. The whole effect of the Hower is very blue. Pkt. IOc; oz. 20c.

PHENOMENAL. White, shaded and edged with lilac; petals delicate and wavy; enormous size, excellent form, exquisite color; fine for cut-Howers. Pkt. IOc; oz. 25.

SALOPIAN. Pure crimson-scarlet. The color is clear and bright, though deep and rich. Withstands the sun better than other reds; large size. Pkt. IOc; oz. 20c.

SYBIL ECKFORD. Standard light salmon and buff; wings buff: medium large open form; frequently four flowers on a stem. Packet ro cents; ounce 20 cents.

Price, anj 3 packets for $25 \mathrm{cts}$; any 7 for 50 cents. The 15 varieties for 90 cents.

NOTE. The fact that some of the above are in the "Incomparable" Collection does not detract from their great merit, but it does add to the value of the collection.

\section{Sweet Peas in Separate Shades.}

Many prefer to grow Sweet Peas in separate shades. It is an undeniable fact that a bunch or vase of flowers of the same or similar shades-as pinks, blues, reds, etc. harmonize better and are more effective than an equal number embracing all colors. For the convenience of those who wish to grow them separate we have carefully prepared the following mixtures:

Red Shades. 8 different varieties, mixed. Claret and Maroon Shades. 8 sorts, mixed. Pink and Rose Shades. Io sorts, mixed.

Lavender and Light Blue. 8 sorts, mixed.

Purple and Dark Blue. Io different sorts. Pure White. About S varieties, mixed.

PRICEs: Each mixture, 5 cents per packet of 90 to 100 seeds; any 5 for 20 cents; the $S$ for 30 cents; ounce, any shade, 10 cents; any 4 ounces for 30 cents.

\section{Our 100 Named Varieties Mixed in Bulk. \\ The Best Low Priced Mixture.}

This splendid mixture is made by taking an equal quantity of each of our 100 Choice Named Varieties, mixing them together thoroughly and filling the packets there from. While we cannot guarantee that you will receive the same quantity of each, you are reasonably certain to receive seed of practically every variety.

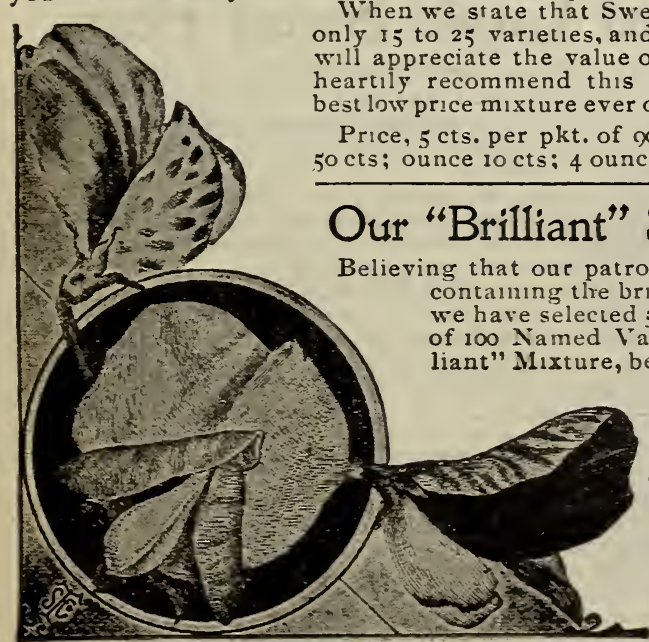

When we state that Sweet Pea Mixtures usually contain 25 varieties, and these of the lower grades, you heartily recommend this mixture as being absolutely the best low price mixture ever offered. We guarantee it to please

Price, 5 cts. per pkt. of 90 to I ro seeds: 6 for $25 \mathrm{cts} ; 13$ for ounces 25 cts; pound $60 \mathrm{cts}$.

\section{Our "Brilliant" Sweet Pea Mixture.}

would appreciate a collection vorieties from our complete $l_{15 t}$ Varieties. We call this our "Brilcause it contains only the most briliant and attractive varieties. varieties of the most distinct, solId colors. Every variety in this cullection possesses sterling mer1t. The packets will be filled by taking two seeds of each of fift $y$ splendid varieties, and will con. tain one hundred seeds.

Price, pkt. 10 cts; 3 pkts. for 25 cts; 7 for $50 \mathrm{cts} ; 15$ for $\$ 1.00$.

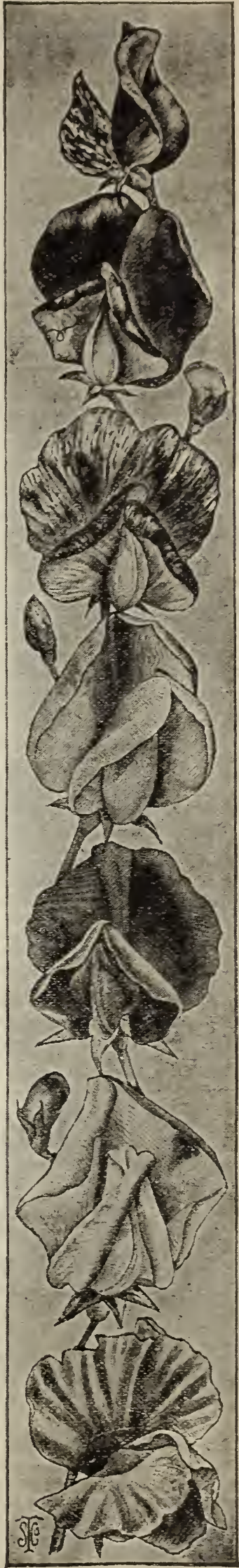




\section{Select Varieties of "Spencer" Sweet Peas.}

\section{Giant or Orchid.Flowered Varieties.}

In the "Spencers" the flowers are ex. tremely large, have beautifully waved or fluted petals, making them very attractive. They are also noted for the charming blendings of their delicate and harmonious colors. The following are the latest introductions of this exceedingly popular class:

Apple Blossom. Heavily shaded and edged with deep pink and soft rose on silvery white ground. Large, waxy petals. A great improvement on the long time popular variety. Price, pkt. of 40 seeds, $15 \mathrm{cts}$.

Asta Ohn The color throughout is a charming soft lavender, suffused $w i t h$ mauve. The first lavender of Spencer type. Very large, distinctly waved and fluted; a free bloomer. Pkt., 35 seeds, 15 cents.

Burpee's Primrose Spencer. A pronounced primrose or creamy yellow throughout. Flowers are large, often four on a stem: standard and wings beautifully waved and fluted. Packet, 40 seeds, 15 cents.

Burpee's White Spencer. A decided improvement on the original white Spencer, being more distinctly waved and fluted. A strong grower and wonderfully profuse bloomer. Pkt., 40 seeds, $15 \mathrm{cts}$.

Dainty Spencer. A great improvement on the old variety of same name. Pure white, beautifully edged with pink on both standard and wings. A decidedly pretty variety. Packet, 35 seeds, 15 cents.

Enchantress. Bright pink, shading deeper at the edges. Practically the same as Countess Spencer in size, form and wavy, fluffy effect, but a little darker in color. Packet, 40 seeds, 55 cents.

Florence Morris Spencer. Delicate blush with pink margins. Very large, open, wavy form of the best Spencer type. Gen. erally produces four blossoms to the stem. Very pretty. Packet, 35 seeds, 15 cents.

Gladys Unwin. A little smaller than most of the above, but of same class. Clear bright light pink, darker at the edges. More free blooming than most other varie ties. Packet, 40 seeds, 15 cents.

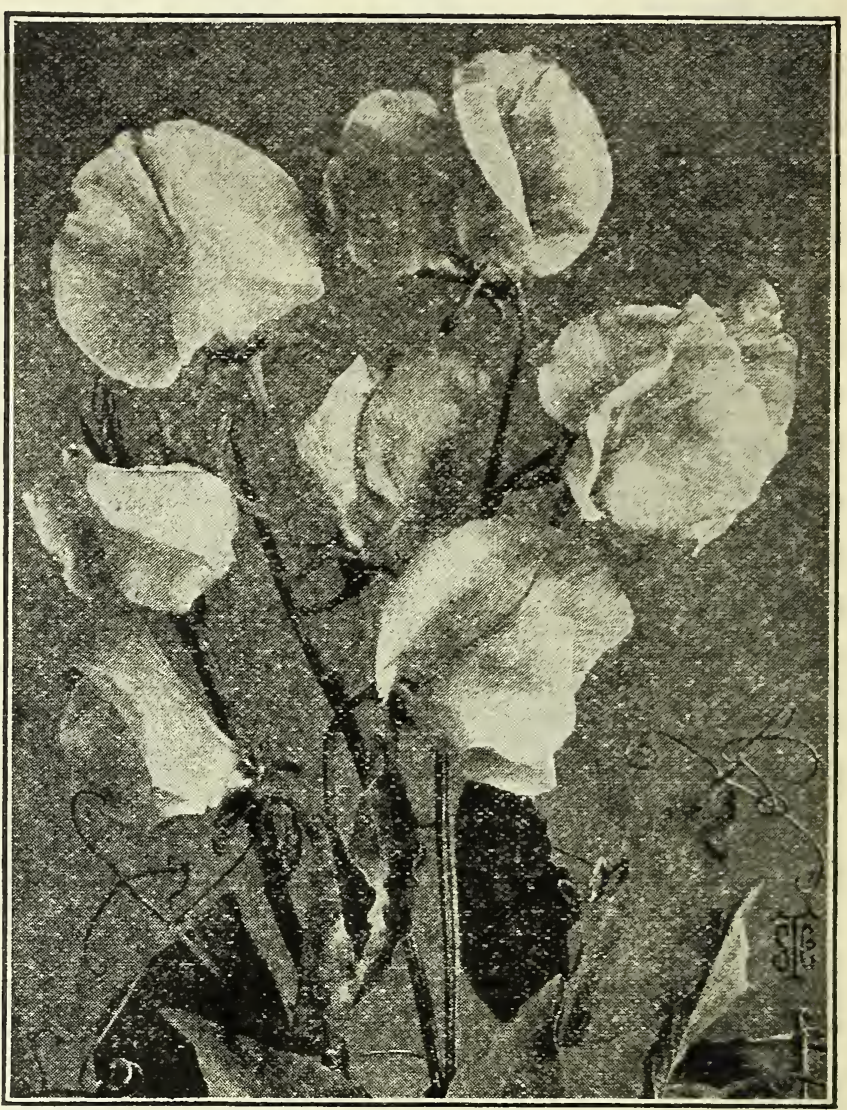

APPLE BLOSSOM SPENCER.

Princess Alice. Color, pinkish lavender and mauve;

riety of same name. Rose, striped on white. Very very large size, open and wavy form of the Spencer
large, of Spencer type. The largest of the striped va.
ryeties. Packet, An exceedingly pretty and attractive variety.

riety of same name. Rose, striped on white. Very very large size, open and wavy form of the Spencer
large, of Spencer type. The largest of the striped va- type. An exceedingly pretty and attractive variety.

riety of same name. Rose, striped on white. Very
large, of Spencer type. The largest of the striped va.
rieties. Packet, 40 seeds, 15 cents. rieties. Packet, 40 seeds, 15 cents.

Price, 25 cents per pkt; any two pkts. for 25 cents; any five pkts. for 50 cents; the ten pkts. for 90 cents, postpaid.

NOTE,-The Spencer Type of Sweet Peas will, doubtless, eventually supercede all other types. Because of their enormous size, the beautiful blending of their delicate colors they well may be called Giant Orchid-flowered Sweet Peas. Three and often four of these lovely flowers are borne on a long, stout stem, rendering them unsurpassed for vases and bouquets.

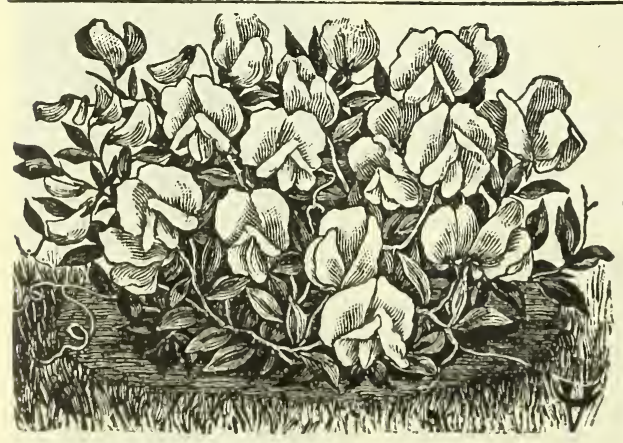

\section{Dwarf Cupid Sweet Peas.}

The "Cupid" is the wonderful Dwarf Sweet Pea that created such a great sensation several years ago. They grow only 6 to $\$$ inches high and literally cover themselves with flowers. Originally there was only the pure white "Cupid" but now we can offer seven distinct varieties.

Alice Eckford. Creamy white and rose. Choice.

Burpee's Beauty. Rich rosy pink. Of excellent quality.

Countess of Radnor. New. Very large; lavender color.

Firefly. Large flowers of dazzling scarlet.

Pink. Bright pink-and-white flowers. Very fine.

Primrose. Rich delicate primrose, with creamy tint.

White. Very dwarf and flowers of pure snow white color.

Price, ro seeds of each, pkt. $10 \mathrm{cts}$; 3 packets for $25 \mathrm{cts}$. Equal nixture of the above, pkt. 10 cts; ounce $15 \mathrm{cts} ; 2$ ounces $25 \mathrm{cts}$.

\section{Our "Banner" Sweet Peas.}

We believe our patrons will greatly a ppreciate this collection. It contains six of the most distinct sorts; two brightest red, two best pure white, two brightest blue. Coccinea. Bright cherry red. White Wonder. Best white. P of Wales. Fire-carmine. Dorothy Tennant. Purple. . of Wales. Trite. Blanche Burpee. White.

Navy Blue. Best blue.

\section{Perennial Peas.}

Common Perennial Peas are the easiest grown, as they are perfectly hardy and thrive almost anywhere. Ra mp. ant growers, splendid for trellises and adapted for cove ering wild, rough places. The roots are long and fleshy, and when once established continue for years withont attention. Best Red, Rose and White. Each 5 conte; the three colors mixed, 5 cents per 100 seeds. 


\section{* General List of Flower Seeds. *}

\section{STANDARD VARIETIES OP GREAT MERIT.}

The following cordensed list contains Annuals and Biennals of great merit: of the easiest culture; of gorgeous beauty. Space will not permit the use of numerous illustrations and full descriptions.

\section{FROM NO OTHER SEEDSMAN CAN YOU PURCHASE SUCH CHOICE MIXTURES.}

\section{ALYSSUM.}

The most desirable and pretto dwarf plants for the border.

Carpet of Snow. Snowy white. dwarf border plant. 400 seed 5 cents; $1 / 40 z .15$ cents.

Little Gem. Pure white: 12 to 15 inches high.com pact grower. 400 seeds 5 cts: $1 / 20 z .20 c$.

Common. White: delicate hon es-like fragrance. Fine for border, 400 seed $5 c ; 1 / 2$ oz, $20 c$.

\section{ABUTILON.}

"Flowering Maple." Drooping Bell-shaped flowers. A fine pot plant. Easily grown from seed. 25 seed 5 cts.

\section{ADLUMIA.}

"Allegheny Vine." One of the finest climbers for trellis, arbors, etc. 75 seeds, 5 cts.

ANTIGONON LEPTOPUS.

"Mountain Beauty." A fine climber for house and yard; pink flowers. 15 seed, 5 .

\section{ARCTOTIS GRANDIS.}

"Blue Eyed African Dais5." Daisy-like, sky-blue flowers. 50 seed $5 \mathrm{cts}$.

\section{ANTIRRHINUM.}

"Snap Dragon." Flowers white, scarlet and yellow; mixed. 200 seed, 5 cents.

\section{AQUILEGIA.}

"Columbine." Fine for hard y bordẹr. We offer Alpina, Bicolor, Canadensis, Cœru1a, Chrysantha, Nivea, Stellata, \&c. Finest mixed. 200 seeds, 5 cents.

ASPARAGUS PLUMOSUS.

"Lace Fern." Most delicate and pretty pot plant. Graceful, feathery foliage. Easily grown. 15 seed 10c; 3 pkts 25 cts.

\section{ASPARAGUS SPRENGERII.}

"Emerald Feather." A fine trailing decorative plant for hanging baskets, vases, etc. Easily grown. 25s. 10c: 3 for $25 \mathrm{c}$.

\section{ASTERS.}

We offer on page 58 the new "Crego" Asters The most beautiful variety for bouquets. vases, etc. I5 cts. per pkt.

On page 59 we offer other splendid nam ed varieties. Also our popular "Prize" Mixed Asters; the best low priced mixture ever offered. Io cts. per pkt.

\section{BACHELOR'S BUTTON.}

Centaurea. Fine border plant. A pretty lower and continuous bloomer. 200s. $5 \mathrm{C}$.

Double. These embrace colors nct found in the single varieties. 200 seed, 5 cts.

\section{BALSAMS.}

Commonly called "Ladies' Slippers." A splendid, gorgeous flowered annual. The varieties we offer are the most distinct. Camella Flowered. Flowers of largest size Finest mixed colors. 50 seed, 5 cents. Carnation Flowered. Flowers beautifully striped and marked. Fine mixed. $50 \mathrm{~s}, 5 \mathrm{c}$ Double Spotted. Beautifully spotted with white. Best mixed colors. 50 seed, 5 cts

Rose Flowered. Unrivaled for size, robust habit and colors. Best mixed. 50s. $5 \mathrm{c}$. Templin's Ideal Mixed. Equal mixtare of the above superb strain. 75 seeds, $10 \mathrm{C}$,
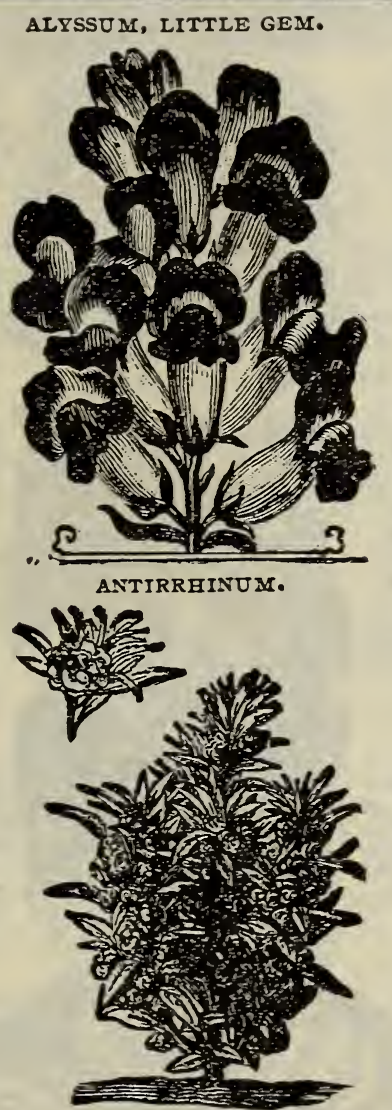

BALSAM PLANT.
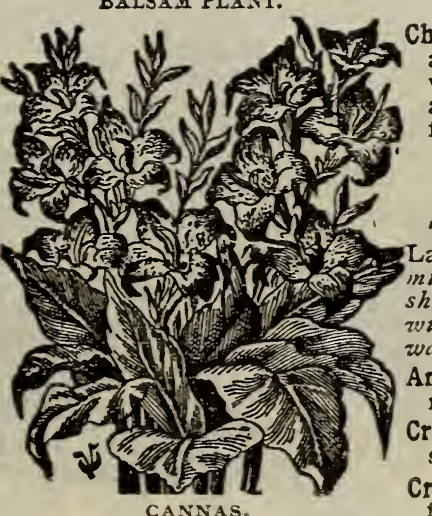

BALSAM APPLE. "Momordica." Very beautiful annual climber. Has curative properties for wounds, cuts and bruises. 50 s. 5 cts.

BALLOON VINE.

"Love in a Puff." An annual climber with curiously inflated seed pods. 50 seed, $5 \mathrm{cts}$.

\section{BRYONOPSIS.}

A wonderfully attractive an. nual with yellow flowers, followed by pretty fruits; color bright scarlet, striped with white. Packet of 75 seeds, 5 cents.

BUTTERFLY FLOWER.

"Schizanthus." A beautiful half-hardy annual, producing highly colored, butterfly-like flowers. Fine as a pot plant. A free bloomer. 200 seeds, 5 cts.

BOCCONIA JAPONICA.

"Plume Poppy." A pretty hard $y$ plant with delicate pink flowers. 200s. 5 cts.

\section{CARNATIONS.}

The varieties we offer are the splendid new French strains of Perpetual Flowering Carnations. They surpass all others in richness and variety of colors

Chabaud's Giant. An improved strain of great merit. 100 seeds 5 cents.

Giant Margaret. Large, semi-double. All colors mixed. 100 seeds 10 cents.

Pure Yellow. A novelty of sterling merit. Will prove very interesting. $100 \mathrm{~s}, 5 \mathrm{c}$.

Templin's "Ideal" Mixed. A superb mixture containing an equal a mount of each of the above varieties. 100s. 10c.

\section{CANDYTUET.}

A popular annual. The flowers are ind ispensable in cut-flower work. We offer the following splendid varieties: Pure White, Umbellata, Coronaria, Odorata, Purpurea, Dunnetti. Choicest mixed colors. 300 seeds 5 cents.

\section{Calliopsis.}

Very free flowering annuals. A lovely flower for in bouquets, vases, etc.

Golden Wave. Flowers goiden yellow with brown centre. 200 seeds 5 cents.

Finest Mixed. This mixture includes all shades of orange, red, etc. 200 s. 5 cts. CHRYSANTHEMUMS,

Chinese and Japanese. These are popular a utumn blooming annuals. The seeds we offer are of the very best Chinese and Ja panese strains. Will bloom the first season. Finest mixed. 100s. 10c.

\section{CANNAS.}

The varieties we offer are of the finest The Flowered strains. To insure germination the hard outer shell of the seed should be cut through to the white kernel with a knife or file, then soaked in warm water for about 24 hours.

American and French. These will produce many good varieties. $15 \mathrm{~s} 5 \mathrm{c} ; 0 \mathrm{z} .25 \mathrm{c}$. Crozy's Hybrids. Finest large flowered strain, mixed colors. 15s. 5 cts; $\theta z .25$ c. Crozy's Dark-Leaved Hybrids. The rery 


\section{CALENDULA.}

Pot Marigold. Free blooming annuals. Produce fine effect in beds or mixed borders. A superior mixture including the Meteor, Orange King, Prince of Orange, Pure Gold, Double Yellow, etc. These cannot
fail to satisfy you. 100 seed $5 \mathrm{cts}$. CAMPANULA.

Canterbury Bell. Produces spikes of bell-sha ped flowers. Mixed. 400s 5c

Cup and Saucer. Curious and showy flowers. Finest mixed. 250s, $5 \mathrm{cts}$.

\section{CASTOR BEAN.}

Zanzibarensis. A stately and highis ornamental tree-like plant, adapted as a centrefor bed of Cannas. Zanzibar varieties, mixed. $6 \mathrm{~s} .5 \mathrm{c}$.

\section{CANARY BIRD FLOWER.}

A beautiful climber. Charming jellow flowers of the most peculiar and interestin
bird-like form. Packet of 20 seeds 5 cents.

\section{CENTAUREAS.}

Very old favorite annuals that bloom free$1 y$ in any situation. They are largely used for cut-flower work, bouquets, etc.

only the large flowered varieties.

Chameleon. Pale yellow turning to lilac. large fragrant variet $\mathrm{y}$. 50 seed $5 \mathrm{cts}$.

Imperialis Alba. A superb large flowered variety of recent introduction. 50 seed $5 c$.

New Marguerite. A superb early summer

bloomer. Fragrant. Finest mixed. 50s $5 \mathrm{c}$.

Odorata. Large size, delicate light blue. Quite fragrant. 50 seeds 5 cents.

Sauveleons. (Yellow Sweet Sultan.) Bright Dusty Miller. (Grmnocarpa.) The old si ver-leaved border plant. 50 seeds $5 \mathrm{cts}$.

Mixed. Including all the above. $75 \mathrm{~s} .10 \mathrm{c}$.

CHINESE LANTERN PLANT.

Produces numerous large inflated seed pods much the shape of Chinese lanterns. Fruits light green, changing to yellow a
bright scarlet. Pkt. of 50 seeds 5 cents.

\section{COLEUS.}

Foliage plants of exceeding richness and beauty. Fine for borders and bedding. Leaf colors include red, yellow, green, crimson, maroon, etc., beautifully blended and combined, and varying greatly in shape. We offer the choicest mixed hybrid varieties. Packet of 100 sceds 5 cents.

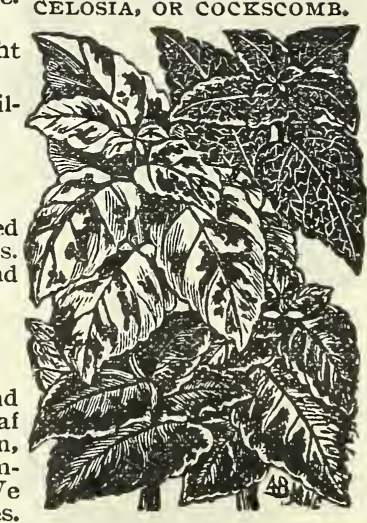

\section{COBAEA SCANDENS.}

One of the finest climbing annuals for arbors, trellises, etc. $50 \mathrm{~s} 5 \mathrm{c}$.

\section{COSMOS.}

\section{GIANT FLOWERED STRAINS.}

Graceful, showy annuals. They attain a height of 3 to 5 feet and their feather-like foliage forms a pretty setting for the hundreds o large, single flowers. They are ex cellent for bouquets, etc.

Early Flowering. "Dawn." dwarf compact habit. Flowers large. Choicest mixed. 150s 10c. New Giant. A tall growing variet $y$, producing very large flowers. Choicest mixed colors. 150s. 10c.

Pink Butterfly. New. Maænificent lovely pink flowers; petals regularly plaited. 100 seeds $10 \mathrm{cts}$.

White Pond Lily. Cha petals.

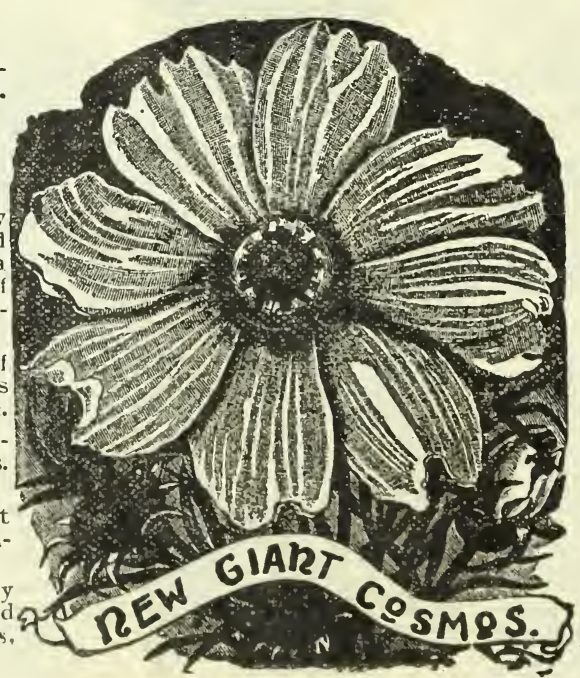

\section{CINERARIAS.}

The most magnificent flowering plant for spring decoration in the window garden, Flowers 2 to 3 inches across, embracing various shades of crimson, violet, blue, and creamywhite: usually two or more colors on each flower.: A continuous and very profuse bloomer.

Grandiflora One of the best large flowered strains; mixed. 50s. 10c. Kermesina. A large, crimson flowered strain. Choice mixed. 50s. 10c. Nana Compacta. A dwarf, compact growing strain: mixed. $50 \mathrm{~s} .10 \mathrm{c}$.

Sanguinea. A new variety that produces blood-red flowers. $50 \mathrm{~s}$. $10 \mathrm{c}$.

Stella. Large flowers with peculiar twisted petals. 50 seed 10 cents.

Any three packets for 25 cents.

\section{CELOSIA.}

"Cockscomb." Attractive annuals. Flowrs borne in great masses of various shapes from that of a cock's comb to a fine feathery plume. Colors ranging from vivid red and

Spicata. Beautiful rose colored flowers. Fin for pot plants. Pkt. of 150 seeds $5 \mathrm{cts}$.

Thomponii Magnifica. Beautiful, plume-like, brilliant red flowers. 150 seeds $5 \mathrm{cts}$.

\section{CYCLAMEN.}

Giganteum. Beautiful window plants. Foliage rich in colors and handsome in shape. Flowers white, pink, crimson, etc. They are exceedingly attractive. 20 seeds $10 \mathrm{cts}$.

\section{CYPRESS VINE.}

A beautiful and rapid growing climber. Foliage delicate, light green; flowers bright rose, scarlet and white. Fine for verandas,
trellises. etc. Packet of 75 seeds 5 cts.

\section{DOUBLE DAISIES.}

Bellis Perennis. Fine for borders, also pot plant. Finest mixed. 200 seeds 5 cts. Snowball. Double, pure white. Finest for bouquets. Packet of 200 seeds 5 cts.

\section{DAHLIAS.}

These are tender perennials that can be easily raised from seed. All choice varieties are produced from seed and the seed we offer are of the very best strains.

Choicest Double Mixed. This strain will produce many good double varieties. 25s. 10c. Choicest Single Mixed. These are noted for their gorgeous colors. 25 seeds $5 \mathrm{cts}$.

\section{DOLICHOS.}

Hyacinth Bean. Climbing annual. Flowers purple and white produced in large racems like Wisterias. Finest mixed. 20 seed $5 \mathrm{cts}$. Princess Helene. "Daylight." One of the prettiest. Snow white, very. fragrant. Pkt. of 20 seeds 5 cts.

\section{DELPHINIUM.}

Hardy Perennial Larkspur. Grand old garden favorite. Flowers are produced in spikes. The shades of blue predominate. $200 \mathrm{~s} 5 \mathrm{cts}$.

\section{SHASTA DAISY.}

Burbank's Giant. This large fowered variety alwars gives satisfaction. A continuous bloomer. Will bloom the first sear form the seed. 100 seeds 5 cents.

JAPANESE CLEMATIS.

A dwarf, hardy, tuberous rooted plant of easy culture. Its beautiful rich blue and white flowers pro-
duced all summer. 150 seeds. 5 cts. 


\section{DIANTHUS.}

"Hardy Garden Pinks." These are bieminials of great beauts and of the easiest culture. For freedom of bluom, brilliancy and variety of colors the Dianthus are unexcelled.

Double Japan. (Heddewigii.) Large, double. Choice mixed. 200s $\bar{x}$.

Double Diadem. Vers shows, fringed and bordered white. 200 seed $5 \mathrm{c}$.

Dianthus Nobilis. Large, fine form, frilled and fringed. Fine for cut flowers. Mixed colors. 200s $\bar{x}$.

Morning Cloak. Double: rich velvety crimson, margined white. Petals beautifully fringed. 200 seed $5 \mathrm{c}$.

Snowball. Large, double, pure white, beautifully fringed. 200 seeds $5 \mathrm{c}$.

Spice Pinks. Very hardy; fine for border. Beautifully fringed; very fragrant. Excellent for cut flowers. Double and single $200 \mathrm{~s} 5 \mathrm{c}$.

"Ideal" Mixed Dianthus. The most complete and valuable mixture ever offered. It includes an equal mixture of all the above varieties. It will furnish the widest pos
ble range of colors. 200s. 10c; $1 / 402.25 \mathrm{c}$.

\section{DIGITALIS.}

Foxglove. Hardy perennials, especially use ful among shrubbery and in half-shaded places. Flowers in long racems; prevailing colors, purple, rose, rellow, white, etc. A superb mixture. 500 seeds $5 \mathrm{cts}$.

\section{GLADIOLI.}

Gandivensis. Magnificent summer blooming bulbs. The seeds we offer are of the best strain procurable and will produce flowers of the widest range of colors and most love15 markings and blendings. 100 seeds $\bar{c}$.

\section{GYPSOPHILLA.}

Angel's Breath. Free flowering annuals. Their delicate, white and pink, star-sha ped, exquisitely fragrant flowers are indispensable for bouquets. 400 seeds $5 \mathrm{cts}$.

Baby's Breath. Delicate little pure white, fragrant flowers. Very popular for bouquets. Pkt. of 400 seeds 5 cents.

\section{GERANIUM.}

Japanese and Italian. These will bloom in five months from seed, producing double and single varieties of great beauty. This is the most desirable mixture ever offered. Piopagation by seed is the way that all new varieties of Geraniums are obtained. Sure to please. Pkt. of 50 seeds $10 \mathrm{cts}$.

Splendid Mixed. A good strain that will produce fine new varieties. 100 seeds $5 \mathrm{cts}$.

Apple-Scented. Popular because of the delicately scented foliage, $25 \mathrm{~s} 5 \mathrm{cts}$.

\section{GAILLARDIAS.}

Lorenzina. Pooular and showr annu. als. Remarkable for size, brilliancy and profusion of flowers. Bloom until frost. Best double, mixed. $100 \mathrm{~s} 5 \mathrm{c}$.

\section{GREVILLA ROBUSTA.}

Australian Silk Oak. A popular fernleaved pot plant. A most gracefur subject for the window garden or centre of a vase. 50 seeds 5 cents.

\section{HARDY HIBISCUS}

Crimson Eye. Flowers 6 to 7 inches in diameter, with crimson eje. Blooms first year from seed. Entirely hardy everywhere. 50 seeds $5 \mathrm{cts}$.

Pink Beauty. Flowers similar to above except color which is bright pink. A beautiful plant for the lawn and open border. Pkt. of 50 seeds 5 cents.

KOCHIA SCOPARIA.

Burning Bush. A highly ornamental annual of bushy form. In the fall resembles a burning bush. $200 \mathrm{~s} 5 \mathrm{c}$

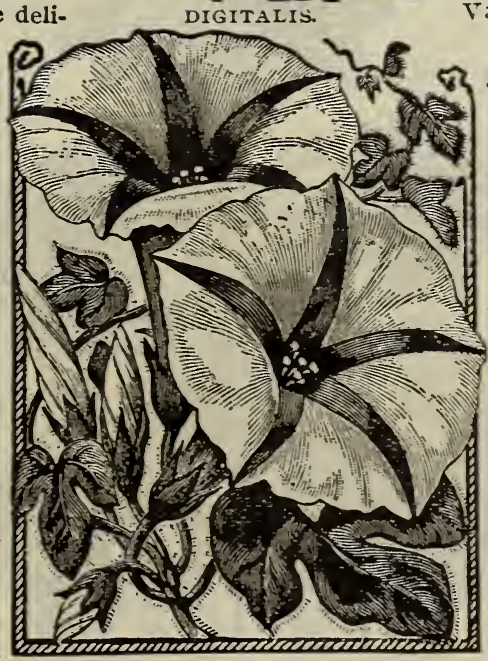

TYPE OF IPOMGE
ESCHSCHOLTZIA.

Golden West. Extremely handsome and rorgeouscanary-rellow flower with an orange blotch at the base of each petal. 200 seeds $5 \mathrm{cts}$.

Dougiasii. A flne new dwarf variety. Lemon fellow with orange mark ings. Profuse bloumer. 200s 5 c.

\section{EUPHORBIA.}

Snow-on-the-Mountain. The foliage is margined with white. Fine for mixed borders. 50 seeds 5 cts.

\section{HOLLYHOCK.}

Chater's Superb. Unequaled in size variety and beauty. We offer a Mammoth Allegheny Fringed. Flowers semi-double, beautifully fringed Finest strain, mixed colors. $100 ; 10 \mathrm{c}$ Ideal Mixed. Finest double, in the richest colors, mixed. $100 \mathrm{~s} .10 \mathrm{cts}$.

HELIOTROPE.

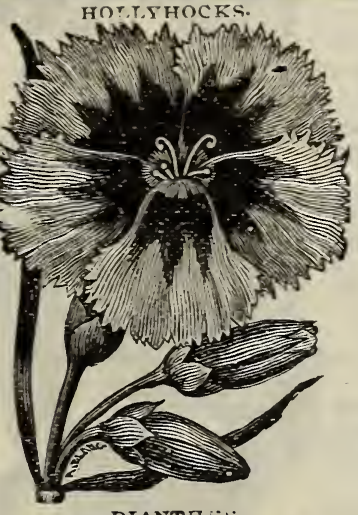

Giant Flowered. Trusses and florets very large and fragrant. We offer the best sorts mixed. 100 seeds 5 cents.

ICE PLANT.

Mesembryanthemum. A dwarf, trailing plant suitable for baskets, vases, etc. Peculiar crystaline siems. $500 \mathrm{~s} 5 \mathrm{cts}$.

KENILWORTH IVY.

A beautiful plant for baskets and vases. Sinall, lilac flowers. 200 seeds 5 cents.

\section{IPOMOEAS.}

Commonly known as "Morning Glory." Most beautiful and rapid climbers of the easiest culture, in the most distinct sorts.

Brazilian. Luxuriant grower with large leaves and star-shaped, delicate pink flowers. Fine for trellises. 25 seeds 5 cts. Grandiflora. (True Moon Flower.) Flowers very large, white, fragrant. Fine for trellises, porches, etc. 25 seeds $10 \mathrm{cts}$.

Purpurea. (Common Morning Glory.) We offer an extra fine mixture, embracing all colors. Packet of 25 seeds 5 cents.

NOTE.-To insure quick germination the hard outer shell should be cut througit to.the white kernel, with a sharp knife or file.

\section{JAPANESE MORNING GLORY.} Valuable for their wonderfully large size brilliant and varied colors and blendings. Choice Mixed. A good mixture, including a very wide range of colors. 50 seeds $5 \mathrm{c}$. Templin's Ideal Mixed. Ruffled and frilled, V ariegated foliage. Unsurpassed. $50 \mathrm{~s} 5 \mathrm{c}$

\section{VARIEGATED HOP.}

Japanese. A beautiful, rapid climber. Foliage streaked and splashed with white. Fine for arbors, etc. $50 \mathrm{~s} \tilde{x}$.

\section{LANTANA.}

Fine, free blooming bedding plants. Finest colors mixed. 100 seeds $5 \mathrm{cts}$.

\section{LARKSPUR.}

Unsurpassed as a border for shrubbers, etc. Choicest mixed, including Rocket. Hajcinth, etc. 200 seeds $5 \mathrm{cts}$.

\section{LOBELIA.}

Crystal Palace. Dwarf habit; fine or border, bedding, and pot culture. Charming blue flowers. 500 seed 5 c.

MUSK PLANT.

Mimulus. Strong musk-scented foliage and yellow flowers. Mixed. 200s $5 \mathrm{c}$.

MUSA ENSETE.

Abyssinian Banana. A splendid tropical-like plant for the lawn. Will not stand frost. Seed large. $6 s$ 15c. 


\section{MARIGOLD.}

Well known annuals that are extremely show $y$ and effective for bedding. We offer the best, African. Tall, upright habit. Finest double mixed. $100 \mathrm{~s} 5 \mathrm{c}$.

French Dwarf. Neat, compact habit. Choicest mixed. 100s $5 \mathrm{c}$ als. Very fine. 100 seeds $5 \mathrm{c}$

MARVEL OF PERU.

\section{Four 0'clock. A handsome, free} flowering, dwarf plant suitable for bordering hedge or shrubbery beds. Fine mixed. $35 \mathrm{~s} 5 \mathrm{c}$.

\section{MAURANDIA.}

Barclayana. A graceful climber for the window garden or open ground. Finest mixed. 200s 5 c. MIMOSA.

Sensitive Plant. Very interesting: the foliage, when touched. will droop as if dead. $50 \mathrm{~s} 5 \mathrm{c}$.

MONKEY FLOWER.

Half-hardy perennials with very showy Gloxinia-like flowers. The colors are varied and beautiful. Require moist soil.

Duplex. Flowers single, but one within another. Blotched flowers. 100 seeds $5 \mathrm{cts}$.

Grandiflora. (Queen's Prize.) Large, gorgeous flowers, blotched and spotted in the most interesting manner. 100 seeds $5 \mathrm{cts}$.

\section{MIGNONETTE.}

Though not particularly beantiful, there is no other flower equal to the Mignotette in delicacy of fragrance. It is valuable for both bedding and pot culture.

Bismark. A giant variets of great merit. Plants robust; very fragrant. $200 \mathrm{~s} 5 \mathrm{cts}$.

Defiance. Spikes 12 to 15 inches long; florets large and delightfully fragrant. $200 \mathrm{~s} 5 \mathrm{c}$.

Glant Matchett. Handsome bush form: flower spikes upright; florets large. $200 \mathrm{~s} 5 \mathrm{c}$.

\section{MYOSOTIS.}

"Forget-me-not." The daintiest of the old garden favorites. Succeeds best in moist and shady situation. Blnoms first season from seed if sown early. Fine for bouquets.

Roya! Blue. (Grandiflora.) New. Flowers large, deeper blue than other sorts. Grow upright, 8 to 12 inches high, 400 seeds $5 \mathrm{c}$.

Choicest Mixed. Including Alpestris, Elegan tissima, Robusta Grandiflora, Pelustris,

Victoria, etc. Finest mixture. 400s $5 \mathrm{c}$.

\section{PETUNIAS.}

The most popular and extensively used annuals for bedding and pot culture.

Bouquet or Nana Compacta. Of dwarf, bushy habit, and a profuse bloom. er. Superb mixed. 200 seeds $5 \mathrm{cts}$.

Dwarf Snowball. For an everblooming white flower for beds and borders this is unequaled. $200 \mathrm{~s} 5 \mathrm{cts}$.

Fimbriata. Finely fringed flowers of larigest size. Superb mixed. 100s 10 Hybrida. Large flowering straiu. A beautifully fringed and ruffled variety in choice mixed colors, 200s $5 \mathrm{c}$

Howard's Star. A superb variety with star-shaped markings in centre of flowers. Mixed colors. 100s $5 \mathrm{c}$

Pure White. Grows 12 to 15 inches in height and blooms profusely all summer. 200 seeds 5 cents.

Double. Produce about 25 per cent of double flowers. A very desirable strain. 100 seeds 10 cents.

Binest Mixed Striped, blotched and veined in endless variety. $300 \mathrm{~s} 5 \mathrm{C}$.
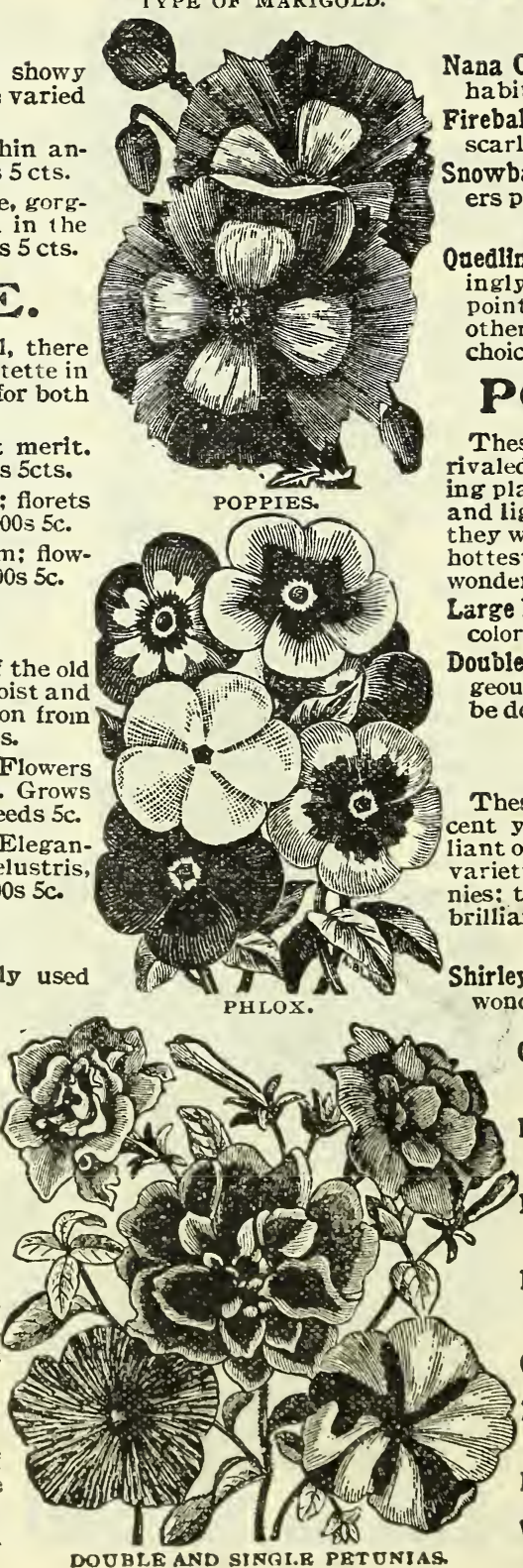
rivaled for brilliancy among the low growand light sand $y$ soil. Planted in a rockers they will flourish amazingly through the hottest and drjest season. There is a wonderful range of colors.

Large Flowered Single. Very dazzling; all colors mixed. 500 seeds 5 cents.

Double Varieties. Most brilliant and gorgeous colors mixed. A large per cent will be double as a rose. 500 seeds $10 \mathrm{cts}$.

POPPIIS.

These have been greatly improved in recent years. They are now the most brilliant of our annuals. Some of the double varieties are as large and double as $\mathrm{Pro}$ nies: the single varieties being wonderfully brilliarit, attractive and graceful. Select Single Popples.

hirley, A charming class. Semi-double, rfully varied and gorgeous in color Fine for bouquets. 300 s 5 cents.

Giant Oriental Hybriass. Unrivaled in gorgeousness and brilliancy. Choicest mixed colors. 300 s $5 \mathrm{cts}$.

Hardy Perennial. Hardy in most climes. Blooms first season if sown early. Superb mixed. 300 s 5 cts. New Tulip. Intense scarlet, tulip. shaped, single flowers. Strikingly beautiful. 300 seeds 5 cents.

New Iceland. Flowers elegant, with lustre of crushed satin. $300 \mathrm{~s} 10 \mathrm{c}$.

Select Double Popples.

Carnation Flowered. Large, dazzling and gorgeous. Mixed. 300 s $5 \mathrm{cts}$. Fairy Blush. White, tipped with rosy cream, shaded at base with lemon. Beautifully fringed. $300 \mathrm{~s} 5 \mathrm{cts}$.

New Iceland. Double, with lovely sat. iny lustre. 200 soeds 10 cents. White Swan. Very large, white, pet als beautifully fringed. $300 \mathrm{~s} 5 \mathrm{cts}$ 


\section{PRIMROSE.}

Chinese. These are justly popular, for the fragrance of their flowers and long continued season of blocm. Of easy culture and never attacked by insects. We offer the single fringed only, as the double seldom satisfs. Mixed. 50 s $10 \mathrm{c}$.

obconica. Very pretty pot plant, being a constant bloomer. Flowers soft lilac. pink, rose and la vender. 100s 10cts.

Officinalis. (Cowslip.) A popular old favorite. Finest mixed colors. $100 \mathrm{~s} 5 \mathrm{c}$. Polyanthus. (Ox-lip.) Hard;: bloom in early spring. Finest mixed. $100 \mathrm{~s} 5 \mathrm{c}$. SCABIOSA.

Mourning Bride Very handsome and popular summer border plants. Flow ers double, very fragrant. 100 s 5 cts.

\section{SALVIAS.}

Drooping Spikes. A grand, new, large flowering variet5, producing nearly three times as many flowers as the ordinary sorts. Gracefull 5 drooping spikes. 50 seeds 10 cents.

Clara Bedman. (Bonfire). Of compact habit. One of the finest for bedding. Flowers most brilliant and dazzling scarlet. $100 \mathrm{~s} 10 \mathrm{c}$.

Faranacea, Quite distinct, producing pretty long spikes of delicate, silvery sky-blne flowers. Excellent for bouquets. 100 seeds $5 c$

Splendens. The popular old variety. Always attracts attention. 50 seeds 5 cents.

\section{SALPIGLOSIS.}

Paiated Tongue. A beautiful flowering annual, highly prized for its brilliant flowers. There is a wonderful range of colors and markings. Useful for bouquets. Choicest mixed. $300 \mathrm{~s} 5 \mathrm{c}$ SMILAX.

A popular climber for the window garden. Used largely by florists for cut flower work, festooning, etc. Easily grown from seed, but are slow to germinate unless soaked in warm water about 24 hours. 50 seeds 5 cents.

\section{STOCKS.}

"Ten Weers Stocks." Popular and useful annuals that are unexcelled in beauty and fragrance. Valuabie for both bedding and pot culture. We offer only the best strains.

Beauty of Nice. A very handsome new winter variety with delicate pink flowers of the vers largest size. Blooms in from 10 to 12 weeks from seed. 100 seeds 5 cents.

Dwarf German. The finest double, large flow ered varieties in best mixed colors. 200 s $5 \mathrm{c}$.

Giant Pefection. Without a rival for outdoor planting. Grows $2 \frac{1}{2}$ feet high, of pyramidal form. Silkes of bloom very long, flowers of enormous size. Best double mixed. 100 s 10 c.

Large Pyramidal. Flowers and spikes very large. Spikes are compact and pyramidal in form and the plants symmetrical in shape. Choicest mixed colors. 100 seeds 10 cents.

Perpetual White. Double, pure white: very fragrant. Grows about 2 feet high. Valuable for winter cut flowers. $100 s \bar{c}$, SWEET WILLIAMS.

Dianthus Barbatus. One of the oldest garden flowers that cannot be surpassed in brilliancy. Choicest double and single mixed, 150 seeds $5 c$.

Giant Double. Beautiful strain with large, double flowers. Choice mixed colors. 150 s $10 \mathrm{c}$

STOKESIA CYANEA.

Stoke's Aster. (Corn Flower.) A charming native flower. Of easy culture; blooms the second year from seed. Color. la vender blue. 75 seeds 10c.
THUNBERGIA.

Black Eyed Susan. A beautiful vine for vases, etc. Flowers white and sellow, with black eye. 25 secds $5 \mathrm{c}$.

TRITOMA.

Flame Plant. A hards plant adapted for clumps on the lawn. Spikes of blazing red flowers. 50 seeds $5 \mathrm{cts}$.

\section{VALERIANA.}

Bardy Heliotrope. Lovely hardy border plant. Red and white flowers: fine for bouquets. 150 seeds $5 \mathrm{cts}$.

\section{VINCAS.}

Pretty plants, for bedding and potcultire Rosea, and White with rose eye, mixed. 75 seeds 5 cents.

\section{VERBENAS.}

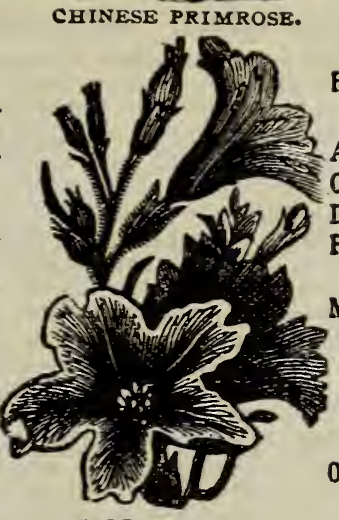

Rybrida Compacta. A new strain, of dwarl, bushy habit. We offer the following distinct and beautiful varieties: Atrosanguinea - Blood-red with white ere. Candidissima-Flowers vers large pure white. Defiance.-Large, brightest scarlet flowers. Purple Cloak.-Dark purple, with white ere. Pkt. of each, 100 s 5 cts. Mixed, 100 s 5 cts. Mammoth. Individual flowers of immense size, embracing a wide range of colors. Fe offer four separa te colors: White, Scarlet, Pink and Striped. Each, 100 seeds 5 cents. Also, All colors mixed. 100 seeds 5 cents.

\section{HARDY VERBENAS.}

Odorata. (Tencrioides). Lemon-scented pure white flowers produced on long spikes instead of clusters. 100 seeds 5 cents.

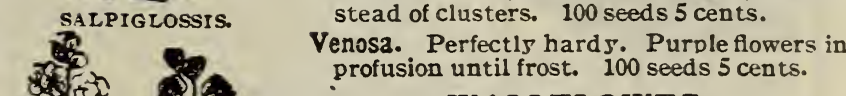

WALLFLOWER.

An old garden favorite. Flowers of various colors, delicate fragrance, and produced in large spikes in early spring. Prevailing colors yellow, brown, purple. Mixed. $150 \mathrm{~s} 5 \mathrm{C}$.

\section{ZINNIAS.}

We offer below a strain of Mammoth Flow. ered varieties that are noted for their unus: ally robust habit, varied and striking colors. They grow 2 to $2 \frac{1}{2}$ feet high.

Curled and Crested. Beautiful, large, perfectly double, with petals twisted, curled and crested. All colors mixed. $50 \mathrm{~s} 5 \mathrm{c}$.

Gold and Scarlet. Flowers large, golden rellow, beautifully scarlet tipped. 50 s $5 c$.

Grandiflora Robusta. A giant flowered, and robut growing strain. We offer these in Choicest double mixed. 50 seeds $5 \mathrm{cts}$.

Sulphurea. A robust grower: flowers very large, double, citron yellow. $50 \mathrm{~s} 5 \mathrm{c}$.

Queen Victoria. A new giant variety, of vigorous growth, with ver 5 double pure white flowers of large size. 50 seeds 5 cents.

Zebra Striped. A pretty Strain each flower beautifully striped and perfect in shape. In varied colors. 50 seeds 5 c.

Double Liliput. Forms perfect little bush. The double flowers are on strong stems: fine for bouquets. 50 seeds 5 cts.

Tom Thumb. Charming little dwarf plants: double flowers of the most brilliant and varied colors. Fine mixed. $50 \mathrm{~s} 5 \mathrm{c}$ Superb Mixed. The most complete mixture ever offered. including all of the above varieties. $50 \mathrm{~s} 5 \mathrm{c} ; 1 / 2$ oz. $25 \mathrm{c}$.

Mexican Hybrids. Novel and attractive. New dwarfs of dazzling beauty. Double mix. ed, 5c. Single mixed, $5 \mathrm{c}$. 


\section{Templins' Brightest and Best Annuals.}

\section{PACKETS OF FIHEST MIXED FLOWER SEEDS FOR 25 CENTS.}

In looking over the previous pages you have, no doubt, found many varieties of flower seeds that 5 ou would like to order, but their combined prices were beyond the amount you had for the purpose; or possibly you could not decide what you really wanted, being in doubt as to which varieties would produce the "brightest and best" effect.

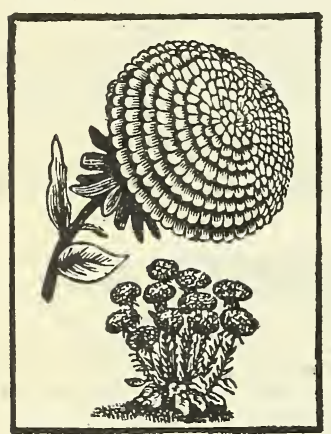

ASTERS.

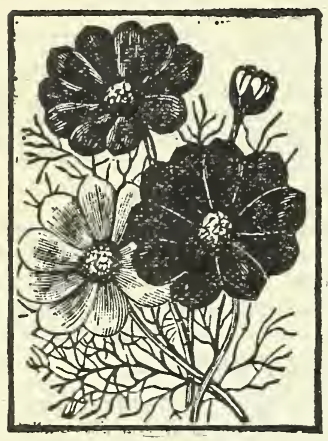

GIANT COSMOS.

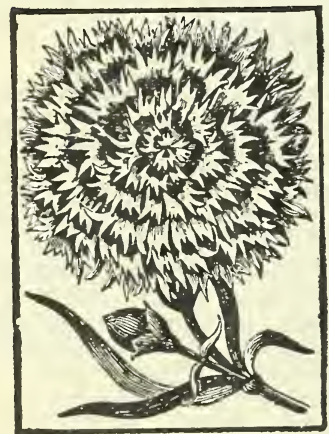

IDEAL DIANTHUS.

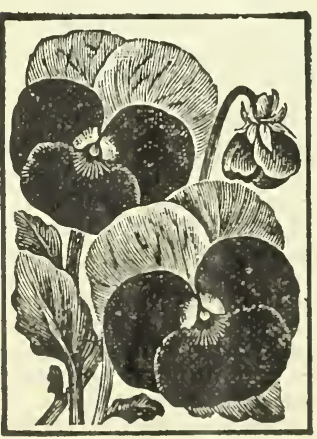

PANSIES.
To aid our customers in securing the greatest possible variety for their money, it has been our custom to offer special collections of seeds, containing varieties best adapted for the purpose indicated. To encourage the beautifying of the home grounds we offer the

\section{BRIGHTEST and BEST COLLECTION.}

It contains varieties which produce the brightest flowers, and are the best for the purpose recommended, and of the easiest culture.

\section{Standard Packets. 10 Standard Varieties.}

ASTERS-Giant Comet or Plume. Probably no class of flowers is attracting more attention, and this particular variety is acknowled ged to be the best. Choicest mixed colors.

COSMOS-New Giant. One of the grandest autumn flowering plants. Foliage is filmy and feather-like; the flowers, which are produced in great profusion, are soft pink and cring

DIANTHUS PINKS-"Ideal Mixed." Flowers are exceeding1y rich and varied in colors. For beautiful cut flowers, ease of culture and freedom of bloom they have no superior. A very com plete assortment of choice varieties.

MORNING GLORY-Japanese Imperial. The great value of this new class is in the large size and wonderful brilliancy and beauty of the flowers. They embrace almost all the colors known to the floral kingdom. Our "Ideal" strain.

NASTURTIUMS-Climbing Varieties. Nothing offered in this catalogue can afford more general satisfaction. The great brilliancy and range of colors is truly marvelous. Best mixed.

PANSIES-0ur Celebrated "International." These are called "International" because they embrace all the choicest varieties grown by Pansy specialists all over the world.

PHLOX-Grandiflora. For a splendid mass of colors and constant display this strain is unrivaled. Strong growers; very large flowers. The choicest varieties grown.

PETUNIAS-New Dwarf Bouquet. Few plants are so popular, and probably in no class has there been so much improvement in recent years. These are dwarf, compact in habit, yet produce finest large flowers. Superb mixed sorts.

SWEET PEAS-100 Named Varieties. The sweetest and prettiest flowers that grow, and this is the largest and most complete collection ever offered. Each packet filled from superb collection of $1 \mathrm{C} 0$ named varieties, carefully mixed.

VERBENAS-Mammoth Flowering. For constancy and profusion of bloom, brilliancy and beauty of colors, and adaptability to bedding and borders, the Verbena is without a rival A packet of the very finest mixed varieties.

NOTE. The above 10 varieties are now put up in separate packets and all enclosed in a large envelope, ready to mail, therefore It will bo im. possible to make any changes.

The above packets are standard size, and each will contain the quantity of seed mentioned in the general description of each variety as shown in the catalogue. Considering the traordinary offer.

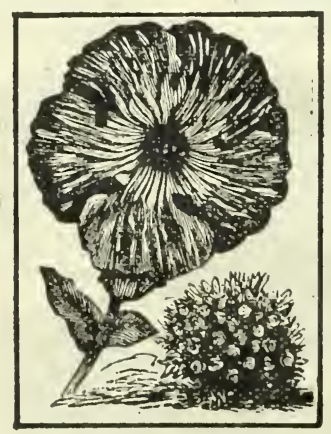

BOUQUET PETUNIA.

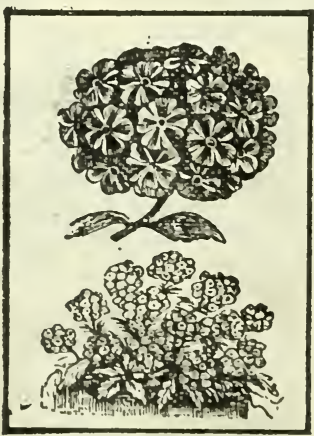

MAM. VERBENA.

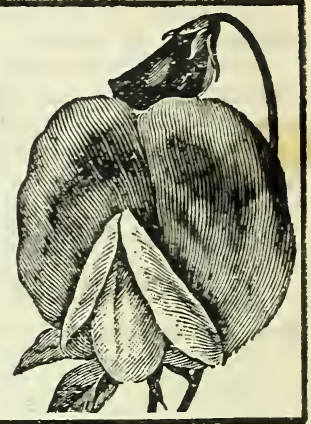

SWEET PEAS.

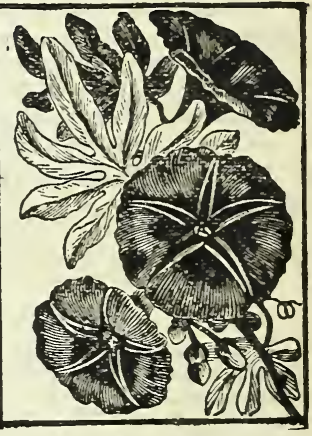

JAP. MORNING GLORY.

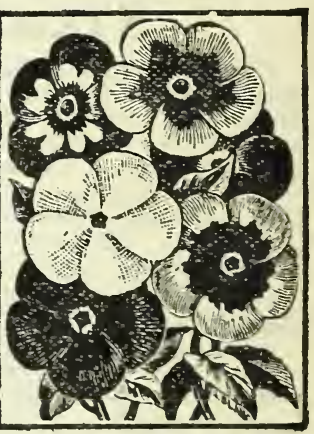

PHLOX GRANDIFLORA.

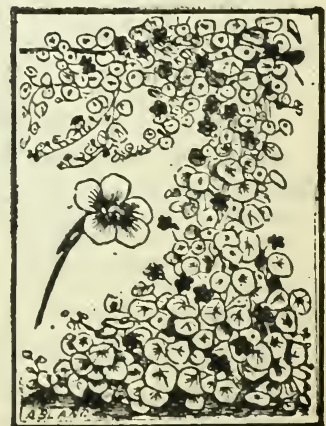

NASTURTIUMS. 


\section{Surprise Flower Seed Collection.}

\section{POPULAR ANNUALS FOR 25 CENTS.}

Nearly everybody possessing a home has a desire to have it as attractive and restful in appearance as possible, and to make it so naturally turn to flowers and plants. Most buyers prefer to have as great an assortment of colors and forms in each variety as possible, and to meet this demand we have prepared this collection. Its equal in variety and quality cannot be found in any other catalogue. They are all easily grown, requiring but little experience.

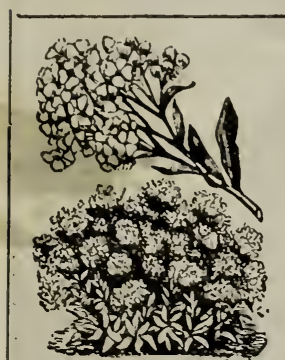

ALYSSUM.

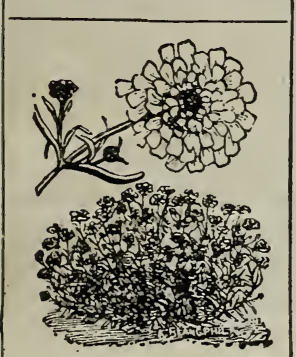

CANDYTUFT。

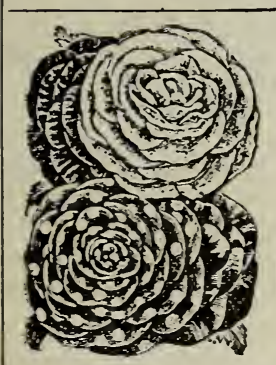

BALSAMS,

SCHOOL CHILDREN Will find this a rare opportunity to buy contains varieties that will bloom with only ordinary care.

ONLY 1 CENT PER PACKET.

Asters. Our "Prize" mixture. A grand assortment. 50 seed Antirrhinum. (Snapdragon.) Choicest mixed colors. 100 seed Alyssum. (Sweet.) Delightfully fragrant. Mixed colors. 25 seed Balsams. Very showy annuals. Finest double mixed. 25 seed Bachelor's Button. A handsome flower. All colors mixed. 35 seed Cacalia. Pretty tassell-like flowers. Finest mixed colors. 50 seed Canterbury Bell. (Campanula.) Very popular. Mixed. 100 seed Candytuft. Iovely for bouquets, etc. All colors mized. 75 seed Dianthus. (Chinese Pinks.) Best fringed varieties mixed. 50 seed Foxglove. (Digitalis.) Very showy. All colors mixed. 100 seed Gaillardias. Showy annuals. Double and single mixed. 50 seed Larkspur. Pretty flowers on long spilkes. Choice mixed. 75 seed Lobelia. A lovely border plant. Bright blue flowers. 100 seed Marigold. Unsurpassed for brilliancy. Double mixed. 50 seed Mignonette. Very fragrant; fine for bouquets. Mixed. 100 seed Morning Glory. Very pretty climbers. Finest mixed. 40 seed Pansies, Popular "Excelsior" mixed. Strictly first class. 50 seed Petunias. Very brilliant. Finest single varieties mixed. 100 seed Phlox Drummondii. Bright and showy. Finest mixed. 50 seed Poppies. Extremely dazzling and beautiful. Best mixed. 50 seed Portulaccas. Low-growing, brilliant. Double and single. 100 seed Sweet Pcas. From unsurpassed mixture of 100 varieties. 50 seed Sweet Williams. Very popular brilliant annuals. Mixed. 50 seed Verbenas. Brilliant. Bloom all summer. Best mixed. 50 seed Zinnias. Large flowered varieties. All colors mixed. 50 seed

NOTE These Collections are already put up the 25 NUTE, small pkts. in a large envelope) ready to mail to our patrons, therefore we cannot allow changes.

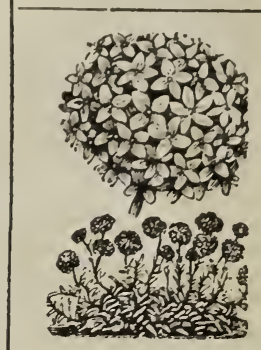

GAILLARDIAS。

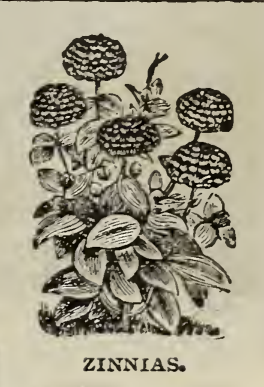

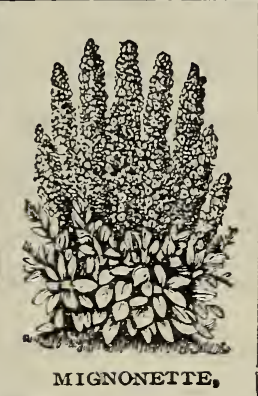
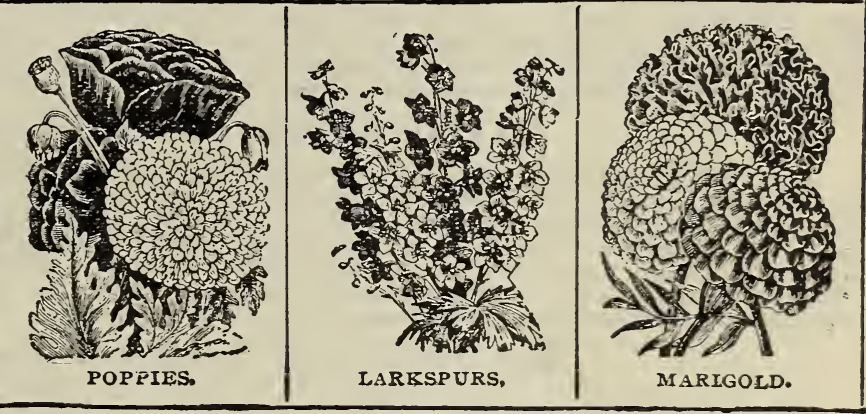

* 3n

Templin's

Special

LARESPURS,

$2 \quad 2$

BOUQUET MIXTURE. In this we include only such an- CLIMBING MIXTURE. For covering old fences, arbors, nuals as are suitable for making bouquets. Ageratum, verandas, etc. They are all rapid climbers. Arabis, BalAster, Brachycome. Bachellor's Button, Calendula, Cos- loon Vine, Canary Bird Flower, Cobcea, Cypress Vine, mos, Chrysanthemum, Dianthus, Gladioli, Gaillardia, Balsam Apple, Japanese Morning Glory, Maurandia, Heliotrope, Marigold, Mignonette, Poppies, and Zinnias. Nasturtium (climbing), Sweet Peas, Produce constant Price, 10 cents per large packet of about 500 seeds.

BEDDING MIXTURE. Prepared especially for a brilliant display on the lawn or garden. Ageratum, Alyssum, Antirrhinum, Asters, Balsam, Cannas, Candytuft, Dianthus, Gaillardia, Larkspur, Marvel of Peru, Mignonette, Nasturtium (dwarf), Petunia, Phlox, Portulacca, Poppy Verbenas. Price, $10 \mathrm{cts}$. per packet of 500 seeds.

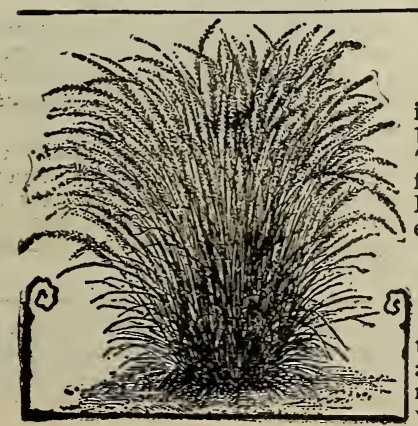

\section{Hardy Ornamental Grasses.}

The wonderful variety and graceful forms of the Ornamental Grasses render them indispensable in the arrangement of bouquets. The plants, used as single specimens beds or groups on the lawn produce effects that are unsurpassed by any other plants. The pendulous, slender foliage and plumes are alwass greatly admired. We offer the following sorts: Andropogon, Cereatochloa, Elymus Arenarius, Elymus Giganteum. Erianthus Ravenna, Eulalia Japonica, Festuca Viridis, Grmnotrix Japonica, Gyn. erium Argentium, Stipa Pennata. Packet, containing equal mixture, $10 \mathrm{cts}$.

\section{Everlastings, or Straw Flowers.}

A grand mixture including the most desirable varieties. Each packet will contain seeds of the following: Accroclinium, Ammobium, Gomphrena or Globe Amaranth, Gypsophilla, Helichrysum Monstrosum, Helipterum, Rhodanthe, Xeranthemum, etc. Never before have you had an opyortunity to procure so many choice varieties in one packet. Price, large packet, 10 cents. 


\section{Templin's "Ideal" Lawn Grass. \\ Unexcelled in Purity and Quality.}

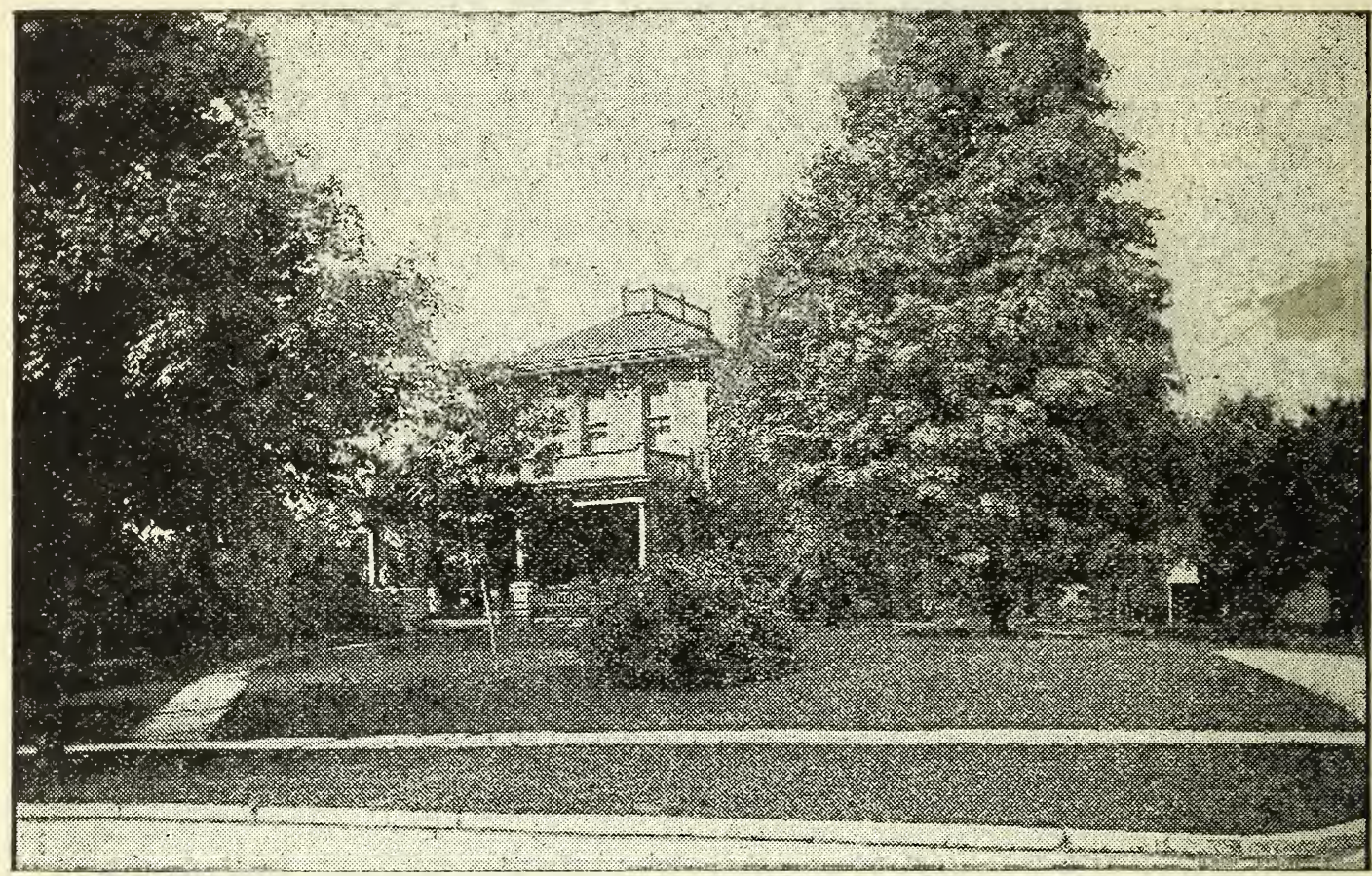

There is nothing that adds so much to the appearance of the home as a nice, well-kept lawn. In order to produce a really fine lawn, very much depends upon the kind and quality of the seed sown. There is much seed sown that will never produce a good lawn. A satisfactory lawn cannot be made with only one kind of seed; there must be a well balanced combination of various kinds of grasses, each of which is adapted to one or more of the prevail. ing climatic and soil conditions, so that a beatiful, smooth, even sod is maintained throughout the year.

\section{No One Variety Will Make a Good Lawn.}

It is a recognized fact that no one variety of grass, however good and pure, will make a perfect lawn. A single variety may, under favorable conditions, produce a beautiful lawn; but conditions are seldom favorable through. out the season. Some varieties thrive best in low, moist soil; others on light, loamy soil. Some require bright sunshine; others thrive best in partial or complete shade. Therefore, it must be evident that a mixture that will be fully satisfactory must contain varieties that are adapted to the varied conditions. We claim for TEMPLIN's "IDEAL" MIXTURE that it contains suffcient varieties, in the proper proportions, to produce a perfect and enduring lawn of luxuriant richness and beauty throughout the year.

\section{The Purity and Quality of Templin's "Ideal."}

There is much difference in the QUALITY of the different varieties of grassessold. In the cheaper grades mach of the bulk and weight are made up of foreign seeds and chaff; the temptation to sell the inferior grades is due to the lower prices at which they are bought.

TEMPLIN'S "IDEAL" MIXTURE contains only the highest grade of extra cleaned seeds; almost entirely free

from chaff. As proof of this, our mixture weighs 25 to 28 pounds per measured bushel, whereas the so-called

"legal" bushel of ordinary mixtures weighs only 14 pounds. A quart of "Ideal" Mixture will produce almost

twice as much as the cheaper mixtures.

Quality. In the preparation of Templin's "Ideal" Mixture we use the latest approved formula, or combina. tion of varieties of the choicest fine-bladed grasses that are used in large City Parks, Golf Links, \&c., where years of practical experience have demonstrated the varieties that produce the best results.

\section{Prices: "IDEAL" MIXTURE.}

This popular Lawn Grass mixture is a careful blending of the best fine growing varieties carefully mixed, each variety in the proportion to produce the best results. Do not compare this mixture with the ordinary grades as generally sold. It is positively the highest grade of Lawn Grass that it is possible to produce. It is absolntely pure grass seed, free from chaff and tested as to germinating power. If you want a fine lawn sow our "IDEAL" mixture. Price, quart 25 cts; 2 quarts 45 cts; 5 quarts $\$ 1.00$, postpaid. By express, not prepaid, 5 pound bag $\$ 1.00$; 10 pound bag $\$ 1.90 ; 25$ pound bag $\$ 4.50$.

\section{"SHADY NOOK" MIXTURE.}

Have you ever had trouble to produce a satisfactory lawn in shady places, under trecs, etc? If so, try our "Shady Nook" Mixture. In this mixture we include varieties that succeed best in shady, moist situations. Price, quart 30 cents; 2 quarts 55 cents.

Quantity Required. A quart of our "Ideal" or will sow 300 "Shady Nook" Lawn Grass 5.000 square feet. of an acre. A smaller quantity may be used but the re sults will not be as satisfactory. 


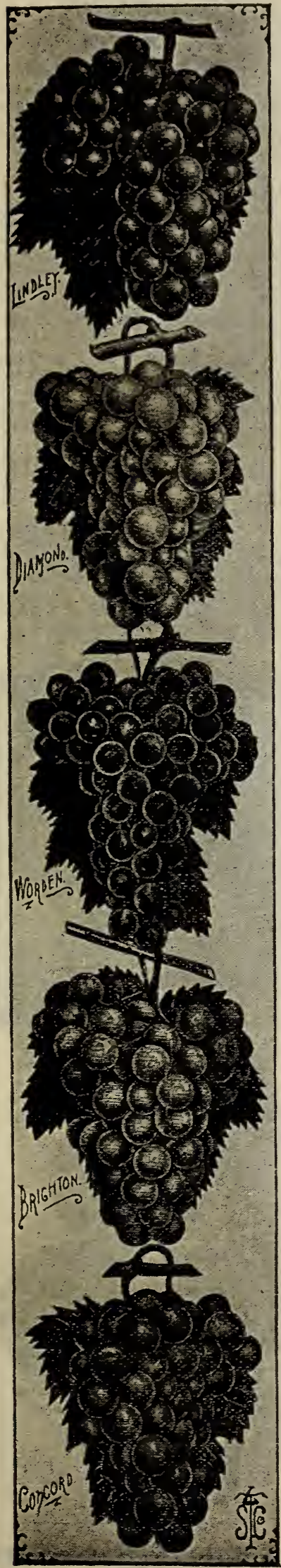

\section{* Templin's "Wonder" Grape Collection.}

For the last fourteen years we have been offering this splendid collection of eiglit $\mathrm{Grape}$ vines for 50 cents. Of course, a few changes were made in the varie ties, by adding new and superior varieties instead of the old. We now offer a
collection that is positively unexcelled in variety and quality. In it we now offer

\section{More Good Vines, and}

More Really High Grade Varieties Than Was Ever Before Offered for Fifty Cents.

With the assistance of our growers, who are the most extensive and reliable in the nation, we have sclected the best eight varieties, considering hardiness, vigor, productiveness and excellency of flavor. They include 3 black, 3 red and 3 white varieties, as follows:

BRIGHTON. Red. Bunch medium to large, long, compact, shouldered; berries medium; skin thin; flesh tender, sweet, with scarcely any pulp; quality the best. Vine a vigorous grower, healthy, hardy and productive. Ripens with Delaware. We know of no better red Grape for table use. I-yr-old Ioc; 2-yr. I5c.

CONCORD. Decidedly the most popular Grape in America, and deservedly so. Black. Bunch large, shouldered, compact; berries large, covered with a rich bloom; skin tender but firm ellough to carry well to distant markets; flesh juicy, sweet, pulpy, tender; vine a strong grower, very hardy, healthy and productive. For general cultivation the most reliable and profitable. I-yr. 10c; 2-yr.15c.

DELAWARE. Red. Bunch small, compact, sometimes shouldered; berries small; skin thin but firm; flesh juicy, very sweet and refreshing, of the highest quality for both table and wine; ripens a little earlier than Concord. Vines hardy, productive; a moderate grower, requiring rich soil and good culture. Is regarded as the best American Grape, all things considered. 1-yr. 10c; 2-yr. I 5 c.

DIAMOND. White, with rich yellow tinge; bunch large, compact, shouldered; berries large, round, adheres firmly to stem; skin thin but tough; flesh tender juicy, with but little pulp and few seeds; quality most excellent. Vine a good grower with thick, healthy foliage; hardy and productive. A fine variety for both market and home use. The leading early white grape. 1-yr. IOc; 2-yr. $15 \mathrm{c}$

LINDLEY. Red. Bunch of medium size, long, not usually shouldered; berries quite large: skin rather tough; flesh tender, sweet, with highly aromatic Aavor; quality of the very best. A good keeper. Vine hardy, vigorous, healthy. It succeeds well in some parts of the South. Requires long pruning and not too rich soil. Price, 1-year-old 10 cents; 2-year-old 15 cents.

MOORE'S EARLY. Black. Bunch rarely shouldered; berries larger than Concord and verv much like it in flavor and quality. Vine a moderate grower, very healthy and hardy; foliage thick, leathery. Produces a fair, and with light cultivation, a heavy crop. Its earliness makes it valuable for an early market. Its hardiness adapts it to Canada and the Northwest. 1.yr. $10 \mathrm{cts} ; 2-\mathrm{yr} .15 \mathrm{cts}$.

NIAGARA. White. Bunch very large and handsome, compact, often should ered; berries large, round; skin thin, tough, does not crack and carries well; has but little pulp when fully ripe; flesh melting, sweet, with a flavor and aroma peculiarly its own, and agreeable to most tastes. Ripens with Concord. Vine very vigorous and productive. Largely planted in vineyards. $1-y r .10 c ; 2-y r .15 c$.

Worden. Black. Bunch large, compact, sometimes shouldered; berries very large; skin thin. Superior to Concord in the following points: Is better in quality, has larger berries, more compact and handsomer bunch and ripens 5 to 10 days earlier. Equals Concord in vigor, health and productiveness, though not quite so good a shipper. We recommend it strongly. $1-\mathrm{yr}$. $10 \mathrm{cts} ; 2 \mathrm{yr}-15 \mathrm{cts}$.

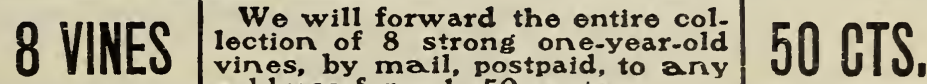

The illustration to the right represents two sets of eight-one and two-year-old; and the splendid root system. Remember they are all fine, dormant, field-grown vines with strong roots, cut back ready for planting when you get them. We guarantee them to give satisfaction both as to the vines and quality of fruit. The illustration to the left shows five of the eight varieties.

\section{Our Special Offer.}

If you will secure orders among your friends and neighbors for five collections and remit \$2.50 we wil send you one collection free for your trouble. Many of our patrons, when they receive their vines, are so well pleased that they secure orders among their friends. You can do the same with but little effort.

TWO-YEAR-OLD VINES, To meet the requent demand of our patrons tortwo-year-o!d vines, we are prepared to furnish the above set in heavy two-year-old vines at $\$ 1.00$ for the set, by mair, postpaid.

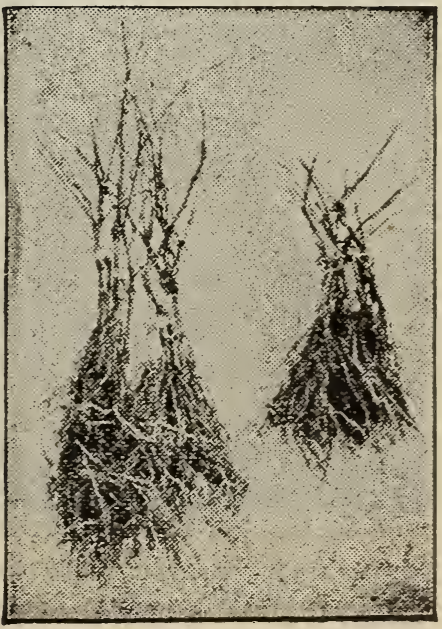




\section{Small Fruits of Special Merit.}

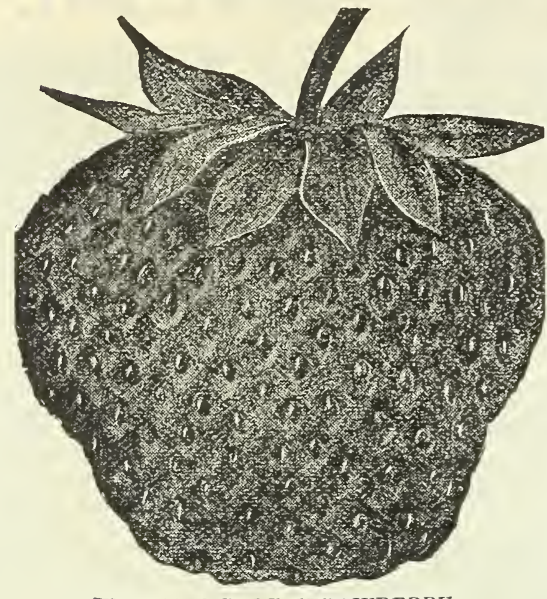

WILLIAX B ILT STRAWBERRY.

The list of Small Fruits offered on this and the next page is not extensive, but we are confident the varieties all possess great merit. We know our patrons will appreciate the list we offer, and would rather select what they want from it than from a long list containing many varieties of only ordinary merit. The following varieties have been grown very extensively by berry growers, and have proven to be the very best sorts:

\section{Select Strawberries.}

Senator Dunlap. Withcut doubt one of the most popular varieties grown. It is especially good for beginners, as they cannot fail to succeed with it on any soil or by any mode of culture. It is taking the place of Warfield with many of the largest growers for the following reasons: It has a perfect blossom; it is better able to resist drouth and rainy weather. The plants are of medium size, produced in great numbers. Fruit is large, conical; color, a deep rich red, extending to the centre. A prolific bearer. Flesh firm, of sprightly, delicious flavor.

William Belt. This is a remarkably vigorous grower, soon covering and shading the ground. Fruit very large, brilliant glossy red; ripens evenly; berries firm: a good shipper and of the finest quality. There are few berries that possess more good qualities. Blossoms perfect. The originator sass: "In productiveness, size, beauts and quality' William Belt will scale higher than any other variety I ever raised."

Price of above, postpaid, 12 for 25 cents: 50 for 75 cents; 100 for $\$ 1.2$. By express, not prepaid, 50 for 40 cents; 100 for 75 cents.

The Grand New Strawberry, "Cardinal."

"Cardinal" is one of the most promising varieties of recent introduction. Planted in trial grounds along witk forty other varieties, it was found to surpass them all in vigor, prodictiveness and other important market qualitics Description. Form, roundish or round ish conical, occasionally slightly compressed or broadened, rarely necked size, medium to large: surface, gloss s bright crimson, not fading; ripens evenly; seeds, small and mostly depressed; calyx, large, tenacious, pale green; flesh, quite firm and solid. salmon red, juicy, but apparently of good shipping qualits: flavor, sub-acid, sprightly, with distinct aroma; qualit $J$, good to very good, especially for canning: season, medium to late, closely following Bubach, about the first week in June in Portage Count 5 , Ohio. (See cut below.)

Price, 12 for $35 \mathrm{cts} ; 25$ for $60 \mathrm{cts} ; 50$ for $\$ 1.00 ; 100$ for $\$ 1.75$, by mail, postpaid. By express; 100 for $\$ 1.50$.

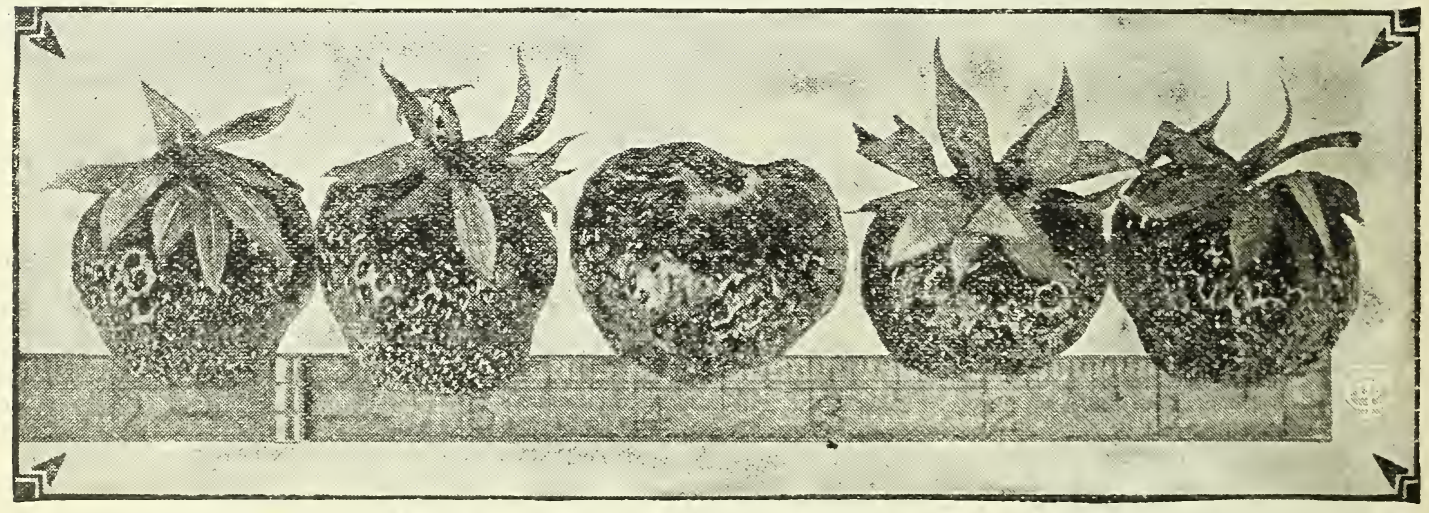

\section{Select Raspberries.}

Columbian. The most valuable and productive red berry. In the Columbian we have a Red Raspberry that will not sprout. It is supposed to be a cross between the popularold Gregg and Shaffer, and combines the qualities of the red with the hardiness, productiveness, and non-sprouting qualities of the black cap. A wonderfully strong grower, and very hardy. The fru, $\mathrm{t}$ is large, purplish red; frrm enough for marketing; unsurpassed fo: canning. (See cut on page 77.)

Cumberland. This is now generally recognized as the best black cap in cultivation. It is called the "Business Black Cap," as it combines more good qualities than any other variety. In hardiness it is all that could be desired. It is admitted to be the most productive; as many as 6,000 quarts per acre have been grown. It is enormously large, running $7 / 8$ of an inch in diameter. Fruit remarkably firm, therefore stands shipping well. Quality first-class, A very st rong, healthy grower, producing stout, stocky canes.

Golden Queen. A beautiful, large, golden yellow berry, seedlir: of Cuthbert, and surpassing that variety in size, beaut $y$ and qualit $y$ : the best yellow Raspberry yet introduced. Canes hards, of strong garden, as its beauty and high quality easily place it in the lead.

Price of Raspberries, 12 for 60 cts; 50 for \$1.50, postpaid. By Express, 50 for $\$ 1.25 ; 100$ for $\$ 2.25$.

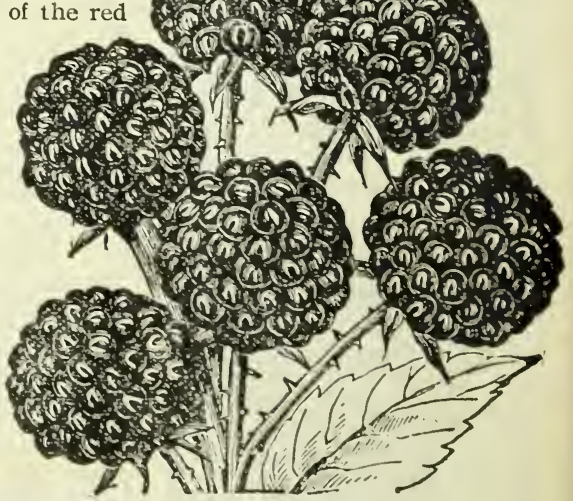

CUMBERLAND RASPPERRD. 


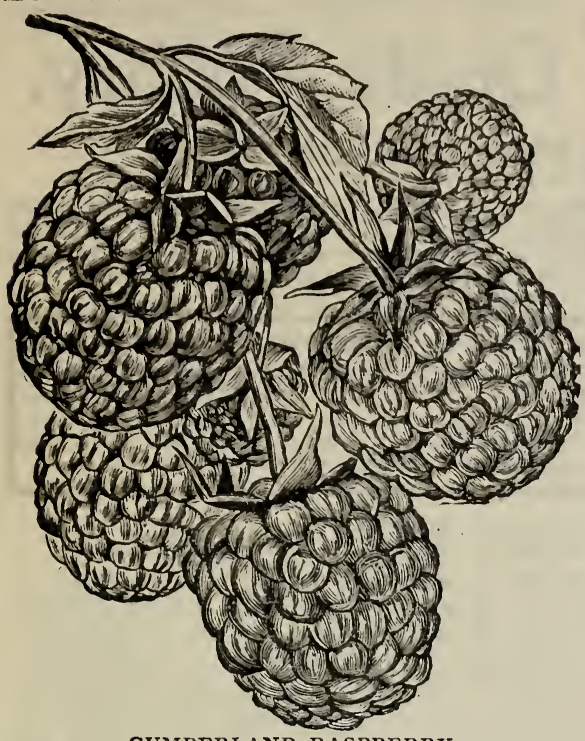

Select Currants.

CUMBERLAND RASPBERRY.

White Grape. Very popular. The largest white Currants. IR a ther spreading; foliage heavy, d e e $p$ green. Bunclies moderately long. Berries very large, whitish yellow, sweet and of exceedingly fine quality. Very productive. Price, 10 cents each; 3 for 25 cents; 12 for 75 post paid.

Wilder. A remarkably fine variety for table and market. One of the trongest growers and most producive. Bunch and berries very large, cright red, hangs on bunches in fine condition as late as any known va-
riety. As compared with Fay's is equal in size, larger bunch, better quality, much less acid, ripens same time, and fully as prolific. I2 cents each; 5 for 50 cents; 12 for $\$ 1.00$.

Perfection. This is a cross between Fay's and White Grape, retaining the valuable characteristics of both parents. Fruits beautiful bright red, larger than Fay's, holding its size to the end of bunch; easy to pick; a great bearer; superior to any other large sort; less acid and better quality than any other large variety. Large, healthy foliage; a splendid grower. If well cultivated and fertilize ed they will regularly produce heavy crops of extra large fruit of exceptionally fine quality for sauce, jellies and preserves. Price, 25 cents each $; 5$ for $\$$ r.oo.

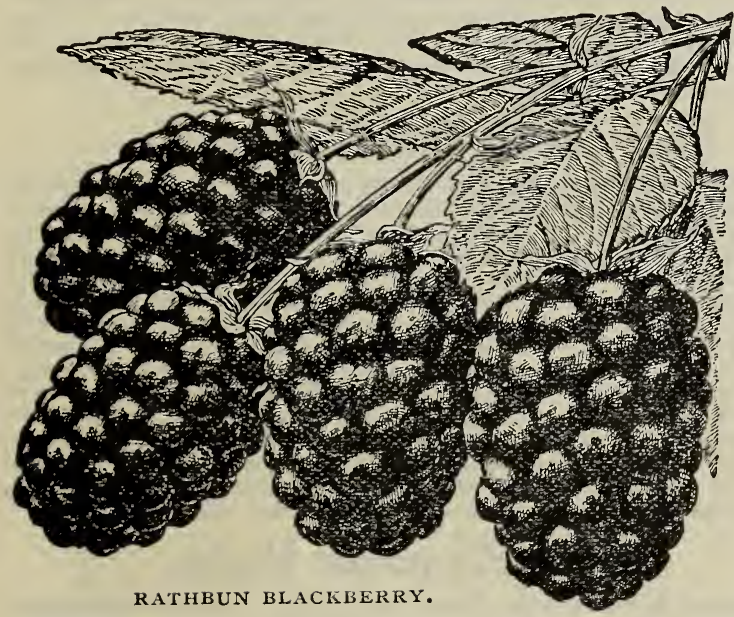

Our Wonder Grape Collection is the greatest offer ever made by anyone. (See page 75.)

\section{Select Blackberry.}

Rathbun. This is probably the largest of all Blackberries. Color, intense jet black, very glossy and permanent in color, having no core and small seeds; extra fine quality and sufficiently firm to carry nicely to market. The plant sprouts very little which is a valuable feature. It makes strong, upright main stems from which the branches start, the ends taking root readily like black cap raspberries. It is remarkably productive and quite hardy. All who want a very large berry of high quality should order Rathbun. Price, I2 cents each; 5 for 50 cents; 12 for $\$ 1.00$.

\section{Select Gooseberries.}

Downing. One of the old standard varieties, and probably as well known and popular as any other sort. The fruits are medium to large and handsome; color, when ripe, pale green; of splendid quality for both cooking

Wilder. Berries medium; pale red when ripe; finest and as a dessert. Bush a vigorous, upright grower, and quality. Of spreading habit, free from mildew. Won- usually free from mildew. An immense cropper and alderfully productive, being literally covered with fine, ways in demand at good prices. One of the best varieluscious berries. A good companion to Downing. ties for home and market. Price, one-year-old Io cents Price same as for Downing.

\section{The Largest and Best Gooseberry Ever Introduced.}

The "Portage." This large and superb variety originated ne a $r$ Mantua, Ohio, Portage Co. Mr. Geo. J. Streator, who first propagated it says: "I have grown "Portage" with the finest American and European varieties and it was easily and decidedly superior to them in every point."

The largest of the berries exceed $11 / 4$ inches long and a good inch in diameter; surpassing in size the largest American and European varieties. Color, when ripe, greenish yellow, and so transparent as to show the seeds. When ripe the quality is unexcelled; the best known variety for dessert. Price, one-year-old, 35 cts; 3 for $\$ 1.00$.

"Portage" has uniformly done well with us; appears to be an European class, but is much less liable to mildew than any other I have seen. It is of very large size and quite prolific."

W.J. Green, Wooter Ex. Sta., O,

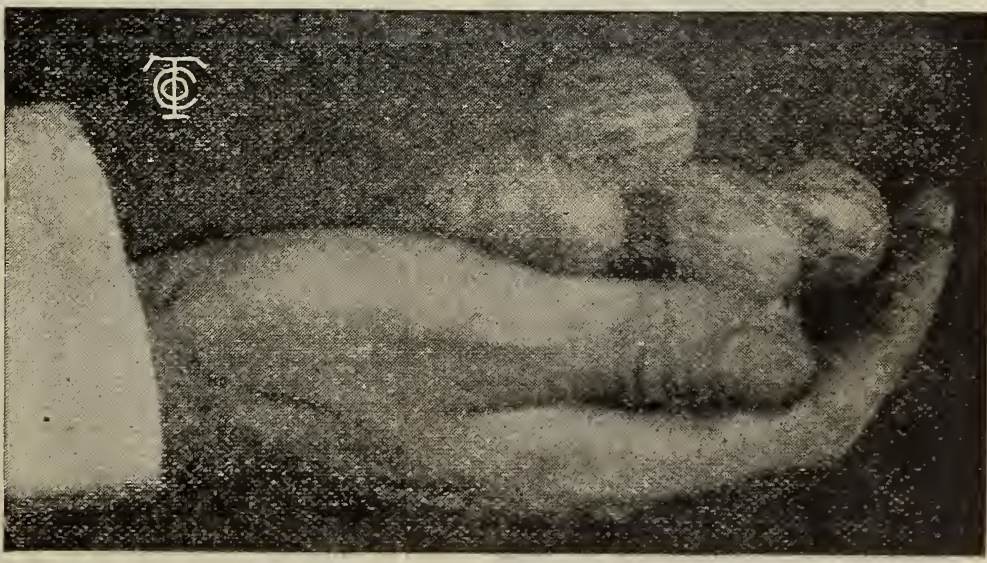




\section{Select Breeds of High Grade Poultry.}

\section{A FEW OF THE BEST GENERAL PURPOSE BREEDS.}

The raising of thoroughbred Poultry has, of late years, grown into one of the most profitable pursuits in which any one can engage. We know of nothing that offers greater profits on the money invested, for the demand for strictly high-grade fowls and eggs always exceed the supply. There never was a time when greater interest was taken in, and a greater demand for really High-Grade Poultry. And the prices paid are always attractive.

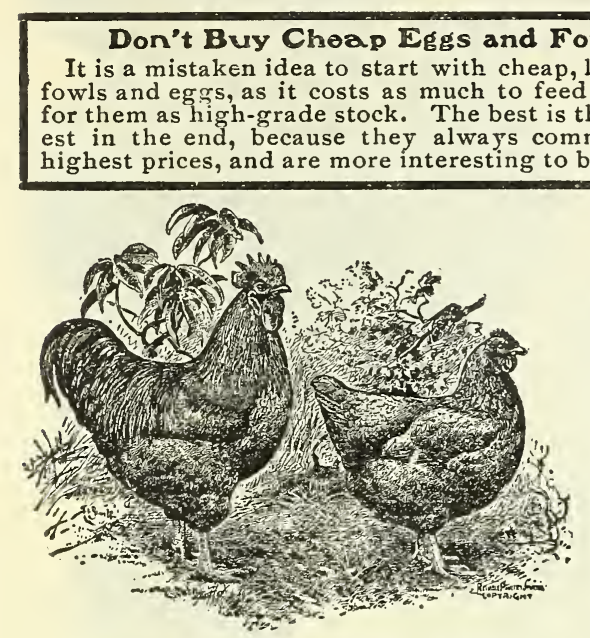

SINGLE COMB BUFF ORPINGTONS.

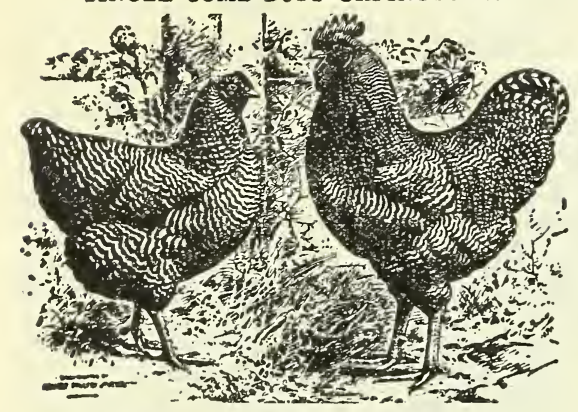

BARRED PLYMOUTH ROCKS.

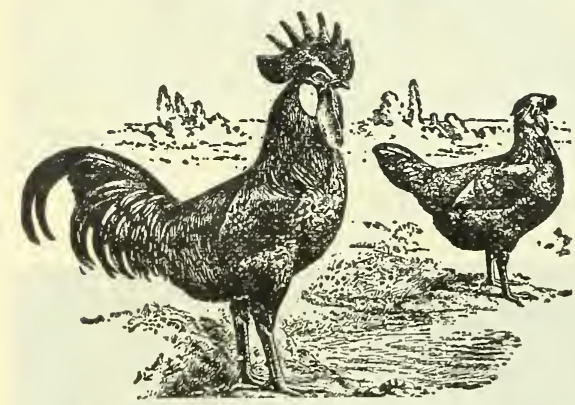

SINGLE COMB BLACK MINORCAS.

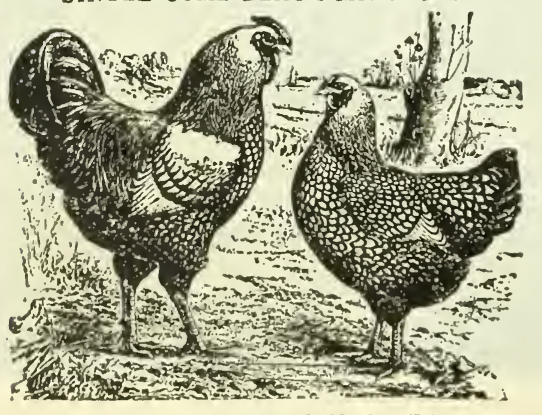

SIIVER LACED WYANDOTTES,

\section{Our Stock is Strictly High-Grade.}

It was all originally purchased from breeders of nat. ional reputation. It is now in the hands of careful and experienced breeders, all on farms where they have free range, hence strong and healthy. We are offering only those breeds that have proven the best.

\section{Single Comb Buff Orpingtons.}

The Single Comb and Rose Comb Buff Orpingtons were first in. troduced into America in ISgS by ourselves and a few other breed. ers. They are now among the most popular breeds. The originator, Mr. Cook, of England, says: "The Orpington fowls have been brought into existence to infuse into farming pursuits a new element of profitable poultry keeping." The Single Comb Buff Orpingtons are of large size; body very compact, with broad and deep breast: back short and broad; legs short and heavy, flesh-pink and free from feathers; ear-lobes and face red; comb medium size; skin and flesh white; color, even, solid buff throughout, comparing favorably with other buff breeds. Chicks are healthy and 7igorous, maturing rapidly. They are persistant layers, in some instances even surpassing the Leghorns; excellent setters and quiet mothers. There is no quality necessary to an all purpose breed that is not found in the Orpingtons. Our fowls are very fine and our matings are sure to bring excellent results.

\section{Rose Comb Buff Orpingtons.}

The Rose Comb Buff Orpingtons are a careful blending of Golden Hamburgs, Rose Comb Dorkings and Buff Cochins, and possess the valuable qualities of their ancestors to a remarkable degree. Though a comparatively new strain, they breed as pure to color and type as any of the old breeds. They are a very attractive fowl; the body being very compact, with broad breast; back short and broad; legs short and heavy, of a delicate flesh-pink color; ear-lobes and face bright red; comb double and of fine form; color of plumage clear even buff throughout. They are exceedingly hardy and vigorous, being as nearly exempt from disease as any fowls we ever owned. The chicks are strong and active, developing quickly into the broiler size and full maturity. They possess not only great size, vigor and hardiness, but excellent laying qualities; are faithful setters and careful mothers. Our fowls are large, of typical shape, and matings are carefully made for best results. (See cut.)

\section{Barred Plymouth Rocks.}

The Barred Plymouth Rock is a breed which owes its popularity not so much to its beauty as to its intrinsic value. It is strictly an American breed, possessing as many qualities for an all purpose fowl as any other. Its universal popularity is sufficient proof of its merit. They are of large size, noted for great vigor and hardiness of constitution, being seldom effected by changes of locality and climate. They are good egg producers, excellent mothers but not inveterate setters. They have a gentle disposition, bear confinement well and are good foragers when allowed to run at large. The chicks grow rapidly, and are ready for market at a very early age. They are an excellent table fowl, making good broilers and roasters. Our stock is of the celebrated Leffell strain. Having full range they are vigorous and healthy. Our matings in the past have given out patrons satisfaction. Our present matings are excellent.

\section{Buff Plymouth Rocks.}

Contrary to what was first predicted, the Buff Plymonth Rocks have become one of our most popular all purpose breeds. They are a cross between the Barred Rocks and Buff Cochins. While in size, shape and stylish appearance they resemble the Barred Rock, 1n color they are a beautiful shade of golden buff. Ear-lobes yellow; wattles and comb bright red; legs rather short, heavy, bright yellow-the color so popular in American markets. They are remarkably handsome and attractive in appearance; just the fowl for the fancier who delights in a thing of beauty. The chicks are hardy, quick of growth, maturing fine broiiers at an early age. Mature fowls are very tame, easily handled. In egg production they are equal to the other Plymouth Rocks; eggs light brown. Faithful setters: careful, quiet mothers. Our stock, having full farm range, is vigozous and healthy, and our matngs such as will bring satisfactory resalts. (See cut opposite page.)

"The eggs came all right; five days on the road. Got I4 strong chicks from the 16 eggs; one dead in the shell; one infertile. Are 19 days old, all strong and healthy." W, B., Middleburg Ctr., Pa, 


\section{Single Comb Black Minorcas.}

There does not exist a more useful, handsome or profitable breed, or one more popular and adapted to the city fancier and farmer alike. They are very stylish, with a carriage as majessic as the stride of a king. They have close, compact bodies and low, stocky, featherless, slate colored legs. The plumage is a beautiful lustrous black, shaded with purple hue, peculiar to some black fowls. The chief and striking ormament of the cock is his comb, which is very large, single, straight and evenly serrated; wattles very large; face coral-red; ear-lobes white. Clicks very hurdy, easily raised, mature early. Pullets commence laying when very young. As an egg producing breed they are unexcelled, the eggs being very large, pure white. Fowls stand confinement well, but require warm winter quarters. Non-setters. Ourstock is of the cclebrated Northrup strain. Our matings contain only large typical birds. (See cut opposite page.)

\section{Rose Comb White Minorcas.}

This is a splendid new breed that is rapidly coming into popular. ity. They possess the one great advantage over the S. C. Black. that of a double, compact comb, making them better adaptcd to sections where the winters are very severe. In size when mature, vigor and hardiness, quick maturity and egg production they are fully equal to the Black. They have close, compact bodies; short. heavy, white and pink legs, free from feathers. In the style, erect and majestic carriage they equal the S. C. Black; eggs very larec, white; non-setters. Are good foragers, yet stand confinemcni well, and the most severe winters. This breed originated with r.ne: of our neighbors-an expert poultryman-who now has the large. and finest birds to be found. His matings can be depended upon for satisfactory results.

\section{Silver Laced Wyandottes.}

The great popularity of the Silver Laced Wyandottes, in so short a time, is without a parallel; it is due to the fact that they are a splendid combination of usefulness and comliness. Indeed, in their makeup they have a blending of the points of excellence of six dis. tinct breeds. Therefore, no one will be disappointed in breeding them if given ordinary care. The plumage is silvery white, heavily laced with black, the tail alone being solid black; the lacing is beautiful. They are medium in size, mature cocks weigh $81 / 2$ pounds; hens $7^{1 / 2}$ pounds. The back is short; breast well rounded, deep and full; legs short, bright yellow; comb low and double, adapting them to cold climates. Excellent winter layers, of large buff eggs; good setters, quiet, careful mothers. Chicks are vigorous and mature early. Our stock is a splendid blending of the celebrated T. E. Orr and $\mathrm{McClain}$ strains. (See cut opposite page.)

\section{White Wyandottes.}

The popularity of this breed is already as wide as the poultry world. Have all the choice qualities of the Laced varieties, with the added advantage of pure white plumage, therefore possibly easier to breed true to color. For beauty, style and fine form they have few equals; plumage pure white; legs short; the yellow legs, beak and skin makes them most attractive to the fancier and market man. Head short and broad; neck short, well arched; back short and broad; breast deep and broad. Their popularity is largely due to their excellent laying qualities; eggs good size, slightly tinged. As setters and mothers they are all that could be desired. Chicks hardy and vigorous and mature early, being unexcelled for market.

\section{White Holland Turkeys.}

This is a comparatively new breed that is very rapidly coming into pubic favor. They have now reached that degree of perfection that they breed remarkably true to color. They possess the general characteristics of the Mammoth Bronze; as to form and size they come to maturity so much earlier as to make them fully as desirable. Are more domestic in disposition than the Bronze-not so much disposed to roam about. Plumage is white throughout; head and wattles bright red; legs pinkish or flesh-color. They present a fine appearance either in the flock or when dressed. Mature toms weigh 25 to 30 pounds; hens 16 to Is pounds. We have a fine flock which have free range of a large farm. They will give satisfaccion.

\section{PRICE OF EGGS.}

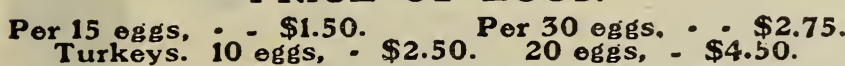

If egrs have been received from a long distance by rail, do not set them until they have rested quietly for about twenty-four hours.

\section{PRICES OF FOWLS.} Males,

Single C. Buff Orpingtons $\$ 2.50$ to $\$ 5.00$ Rose C Buff Orpingtons Barred Plymouth Rocks Buff Plymouth Rrcks 2.50 to 5.00 2.50 to 5.00 2.50 to 5.00 Single Comb Bl'k Minorcas 3.00 to 6.00 Rose Comb White Minorcas 3.50 to 7.00 Silver Laced Wyandottes 2.50 to 5.00 White Wyandottes White Holland Turkeys

\section{Females,}

$\$ 2.00$ to $\$ 3.00$ 2.00 to 3.00 2.00 to 3.00 2.00 to 3.00 2.00 to 3.00 3.00 to 6.00 2.00 to 3.00

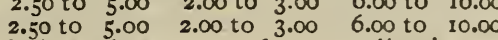
Prices given promptly on application.

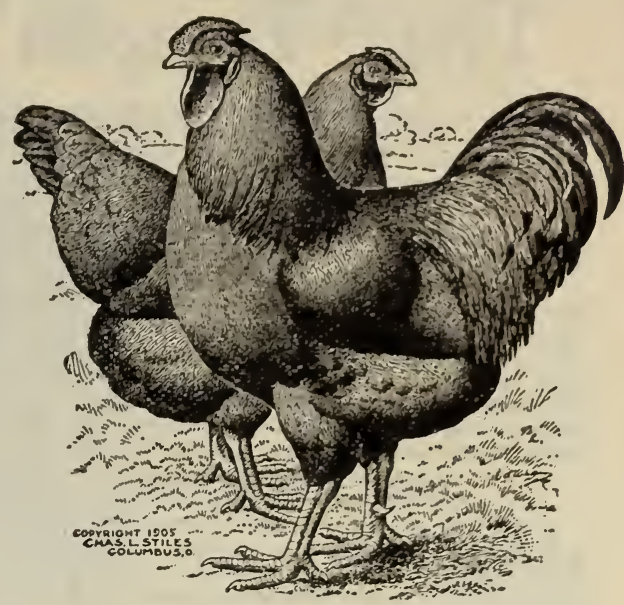

ROSE COMB BUFF ORPINGTONS.

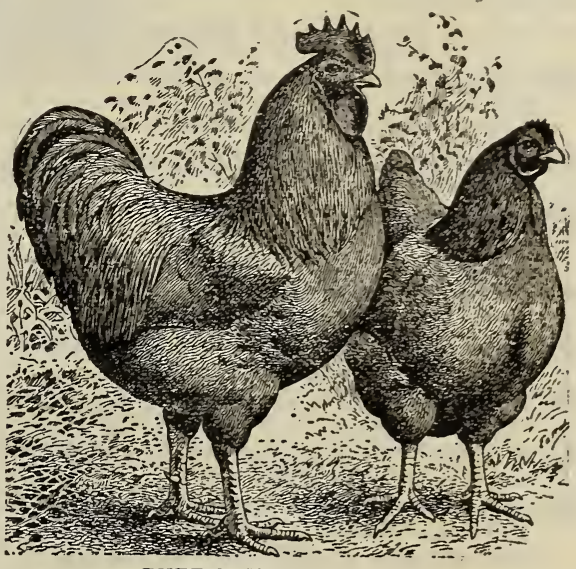

BUFF PLYMOUTH ROCK.

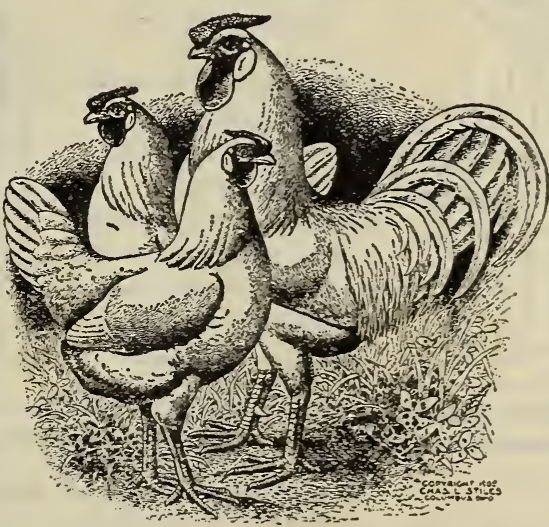

ROSE COMB WHITE MINORCA.

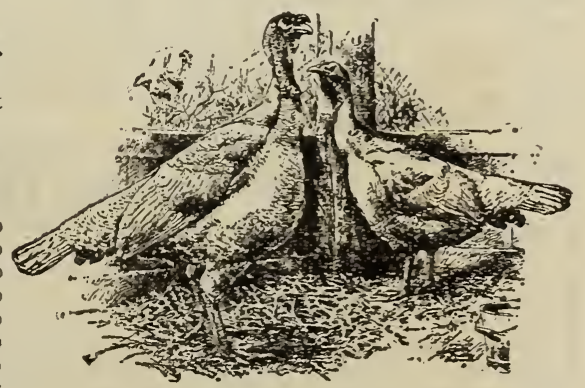

WHITE HOLLAND TURKEYS. 


\section{The "Templin" Bucket Spray Pump.}

THE BEST BUCKET SPRAY PUMP ON THE MARKET. HE history of spraying would be interesting, but much more so would be the
history of the development of the a ppliances used for spraying. which have today reached so high a standard of perfection. The appearance of insect and fungus enemies to fruits and flowers have made the Spray Pump indispensable; the Bucket Spray Pump is the most practical form for the a verage Family Garden.

The Essentrals of a good Buclet Spray Pump are (1) durability: secured by having all working parts made of brass, as copper compounds corrode iron and soon render it worthless. (2) Strength; obtained by a good-sized crlinder, substantial valves, wall and piston, made of indestructable material. (3) Easy working; found only in a pump having a large air-chamber and smoothly finished working parts. (4) Compactness; so as to facilitate the working and moving about, and not so top-heavy as to fall over when set down. The above and several other valuable features are claimed for the "Templin" Spray Pump.

\section{LIGHT, REAT, COMPACT, STRONG, DURABLE.}

A good Bucliet Spray Pump is now recognized as a necessity in every greenhouse, conservatory, garden, orchard or vinegard, for applying the various kinds of Fungicides and Insecticides; being much more convenient and effective than the brass syringe formerly used for these purposes. They have also become popular for washing windows, buggies, spraying poultry houses, etc.

\section{Points of Superiority.}

It is durable and strong, because all working parts ex. posed to sprayng compounds are made of brass; and the handle, foot rest und clamps are made of malleable iron.

AS It is double acting, forcing out a continuous stream or spray with both upward and downward strokes.

Hig has the largest and most perfect air-chamber of any Bucket Spray Pump made: the plunger being hollow, gives air space in addition to the air-chamber.

190 It has adjustable bucket clamp, which can be quickly adjusted to a bucket or tub oj any thickness.

It has an adjustable foot rest which can be readily adjusted to a bucket of any depth.

HOF It has a clamp for holding the bucket handle in an up. right position, ready for im mediate use.

HG It is fitted with bronze ball valves which wlll never wear out nor get out of order.

49 It is fitted with four feet of best hose and the celebrated Bordeaux Nozzle that will throw the finest spray or a solud stream. It is the best nozzle made.

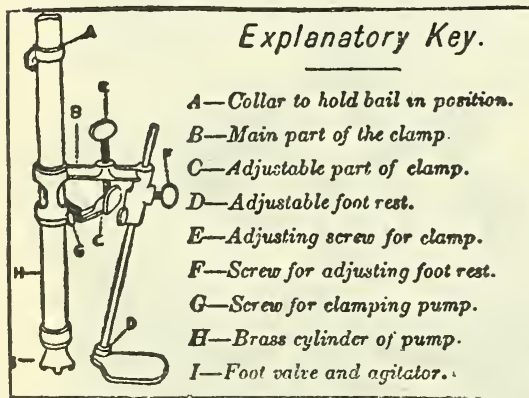

We have carerully examined the merits and demerits of the different Bucket Spas Pumps on the market, and have had a Special Pump manufactured expressiy for us - according to our suggestions-which we believe Dossesses more valuable teacures than any other Pump on the market. After using one of these Pumps continually, in our greenhouses, for a number of years, we knov nor wherein we could improve it.

SIICRCS in spraying is a matter of detail. Little things, seemUUULJ ingly unimportant, will affect results. The thing of must vital importance is to ha ve a sprayer that will throw an exceedingly fine spray or mist, so that the surface of the foliage may be thoroughly covered with emulsion. This is also necessary as a matter of economy, as a lesser quantity of emulsion is required to do effective work if thrown on in a mist, than in a heavy spray. The Templin Spray Pump, with the Bordeaux Nozzle, is pos itively unequaled as a sprayer. The price of a Pump can be saved the first season, by the spra ying of a single tree.

Price complete backet aof incladed with 4 feet of hose and celebrated Bordeaux Nozzle, \$4.00. Seven foot extension hose, with ccupling and pole connections, for spraying tail trees, $\$ 1.00$ extra.

What Our Patrons Think of Our Spray Pump.

"On trying your Spray Pump I found it very easy to operate, and could throw a solid stream fifty feet with little trouble and the spray in proportion. The bucket attachment holds the pump steady even when bucket is empty. It is by far the best pump I ever used." Yours, IF G. Needham, Atwater, O. Gentlemen: "I received the Spray Pump; and, like everything else you handle, the name "Templin" is a guaranty of quality. 'The Pump and Nozzle are a success in every particular; all you claim for them. Have dealt with your firm for 20 years and $m \mathrm{y}$ deal ings have always been satisfactory." W. M. Connell, Toledo, Iowa.

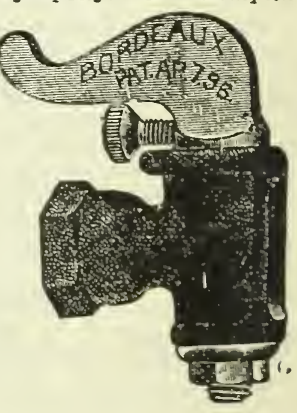

\section{A Valuable Handbook on Spraying Free.}

"Spraying For Prufit." The aim in the preparation of this work has been to place in the hands of the farm- er, fruit grower and gardener a small, practical handbook for ready reference, describing briefly but thor a pressing insects and diseases injurious to plant life. The advantage of this work over other similar works, lies in its simplicity; treating as it does on the new formulas that have, by years of use, proven to be practical for the amateur. This little book is indispensable to those who use a spray pump. Regular price 20 cents each, by mail, postpaid. We send a copy FREE with every spray pump we send out. 


\section{Shetland Ponies for the Children.}

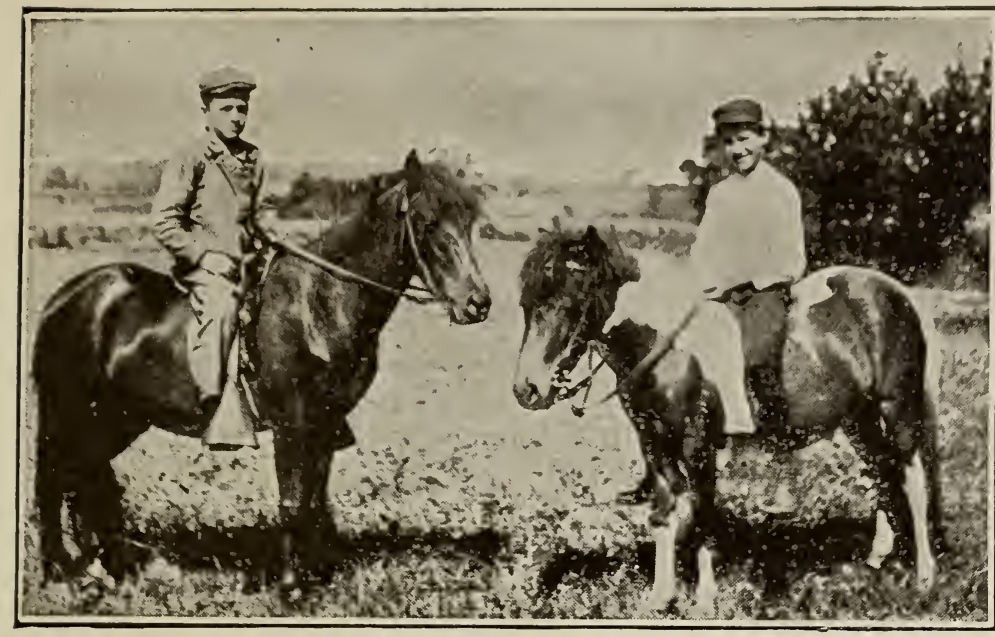

WOULDN'T YOUR BOY BE PROUD OF ONE OF THESE.
Most children admire flowers, and are fond of good vegetables, well cooked, but neither of these, or anything else in this catalogue will so strungly appeal to them as a grood live pony.

Boys and Girls, we have a fine stock of ponies,-real live ponies. The picture opposite shows what two of them look like, with boys oll their backs. Ask palra if you wouldn't look nice on a pony.

Parents. There is not a thing in the world, anlmate or inaui. mate, that would make a better birthday or holiday present, and companion for your children, or that would be more conducive to their good health.

NOTE. If you have any preference as to color, mention it; send 5 cents in stamps for postage and wrapping and we will send you a photograph of the pony nearest the one you describe, also prices.

\begin{tabular}{|c|c|c|}
\hline $\begin{array}{l}\text { GRAPE } \\
\text { VINES } \\
8\end{array}$ & $\begin{array}{l}\text { Good Vines, Good Fruit, Good Price. } \\
\text { On page } 75 \text { we offer our popular "IVonder" Grape Collection. First of - } \\
\text { fered fourteen years ago, and thousands of them sold every season. You } \\
\text { canl't get better vines or varieties anywhere and your local nurseryman } \\
\text { will charge you } \$ \text {. oo or more for them. We send them postpaid, for } 50 \text { cts. } \\
\text { You can easily find room to plant them. }\end{array}$ & $\begin{array}{r}\text { GRAPE } \\
\text { VINES } \\
8\end{array}$ \\
\hline $\begin{array}{l}\text { For } \\
50 \text { Cents. }\end{array}$ & $\begin{array}{l}\text { "Three years ago we ordered the Grape collection; they have made phe- } \\
\text { nomenal growth. Last year we gathered } 75 \text { bunches of N1agara and } 72 \text { of } \\
\text { Brighton. Two Nragara bunches weighed I1/8 pounds each. We are hop- } \\
\text { ing great things from them this year." } \\
\text { H.K. B., Marshalltown, Iowa. }\end{array}$ & $\begin{array}{l}\text { For } \\
50 \text { Cents. }\end{array}$ \\
\hline
\end{tabular}

* General Index to Contents.

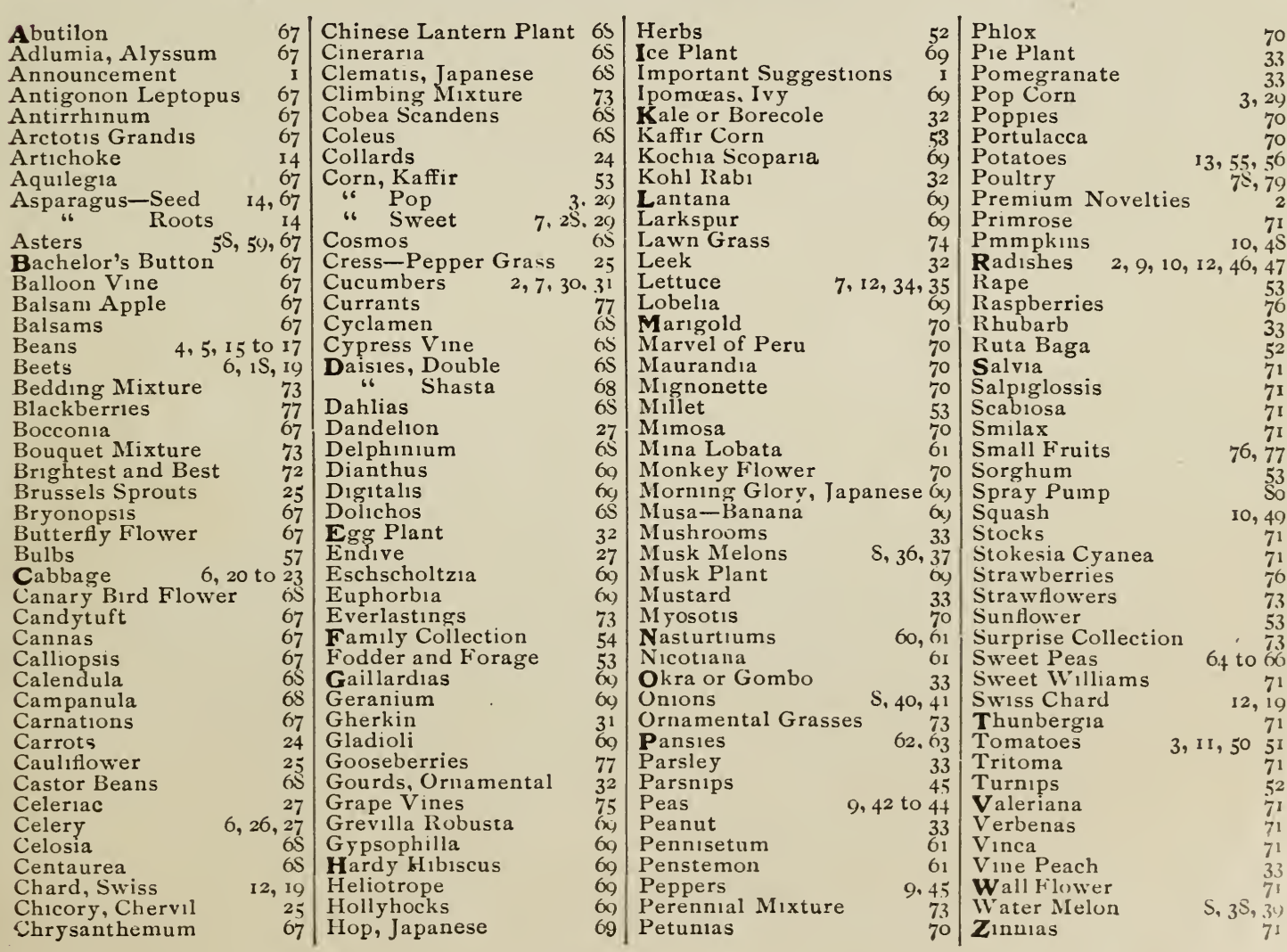




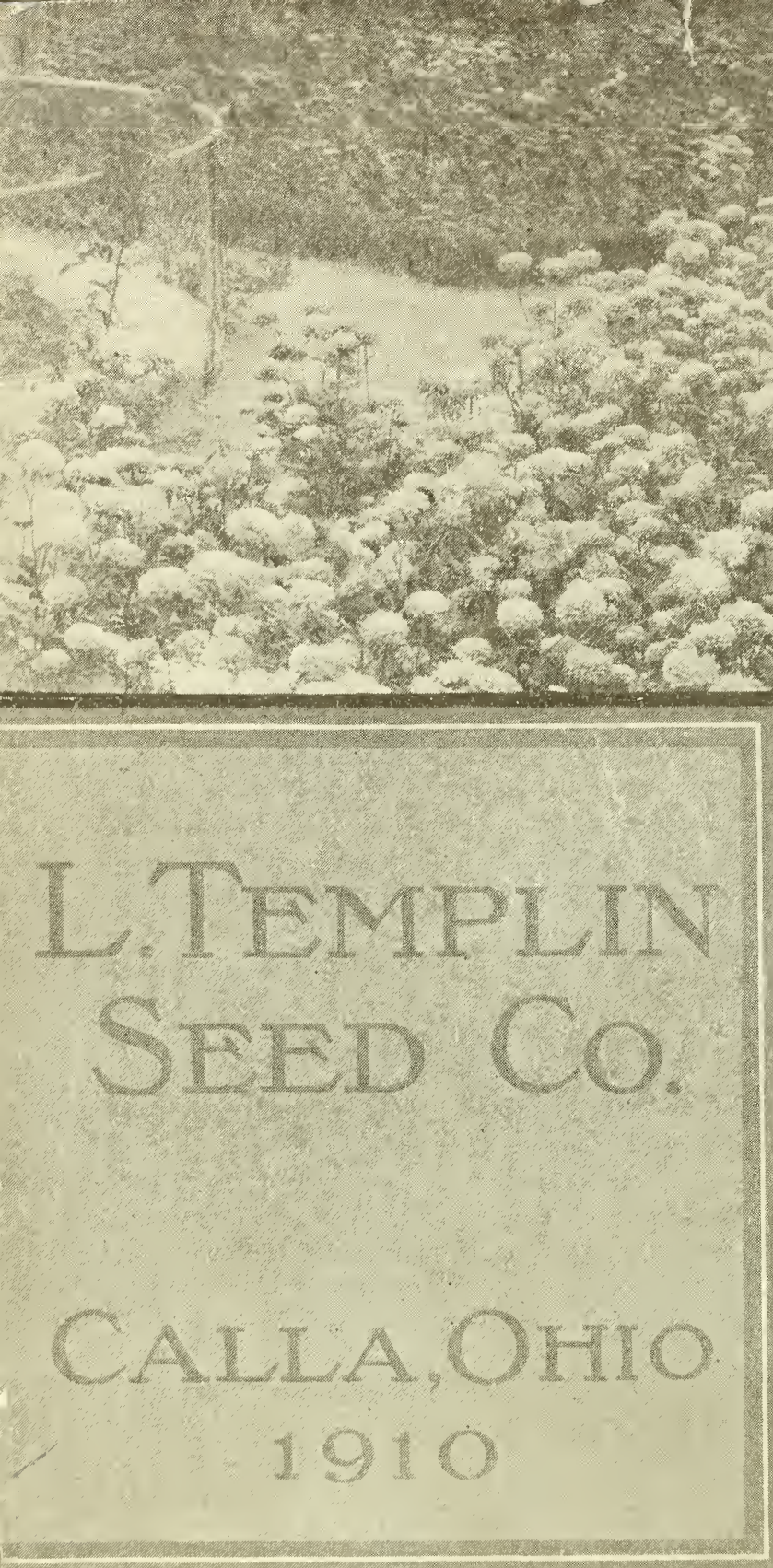

$-2,3-10$

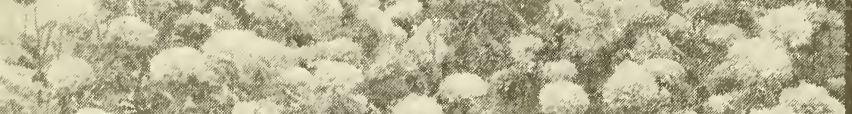

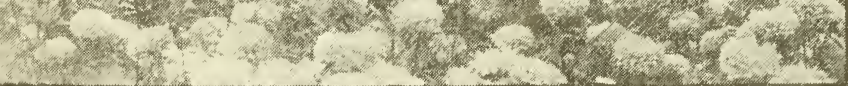

I

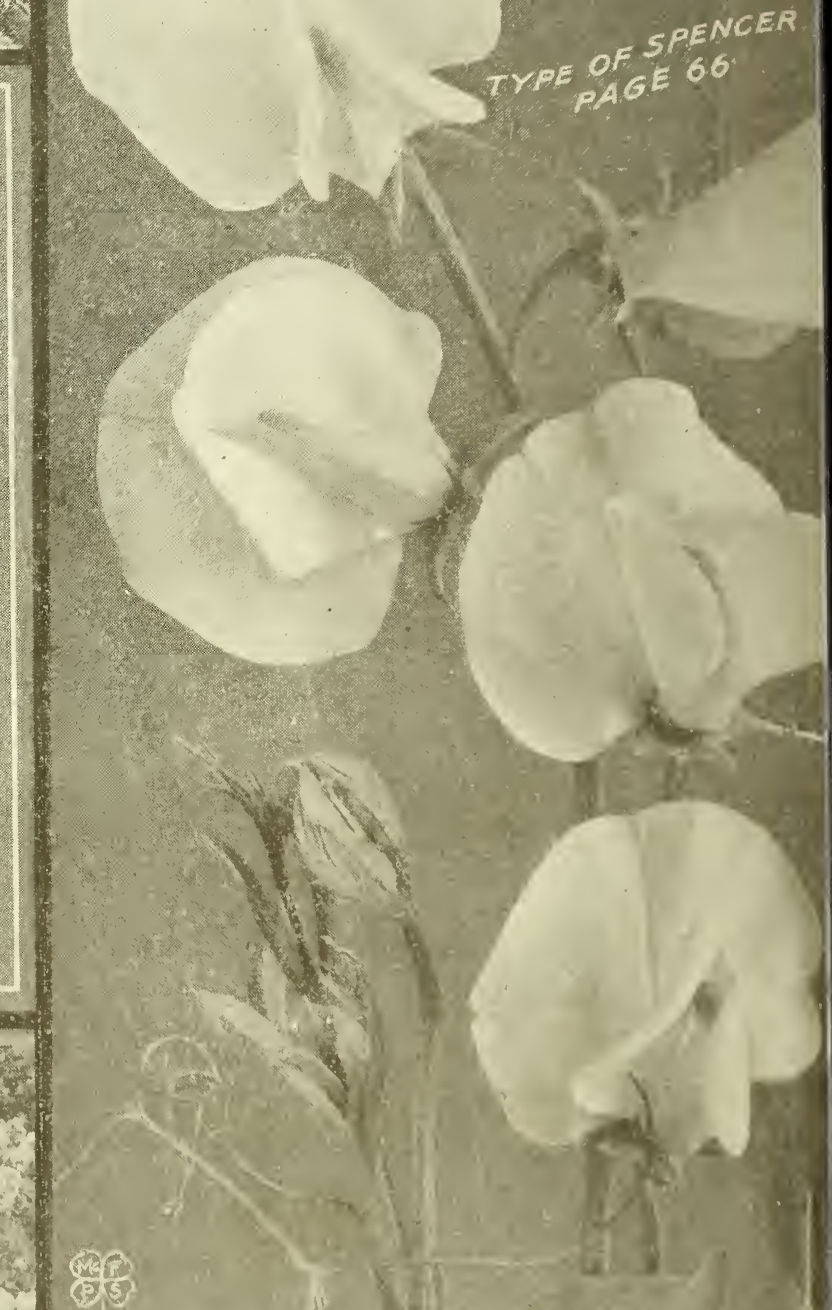

To

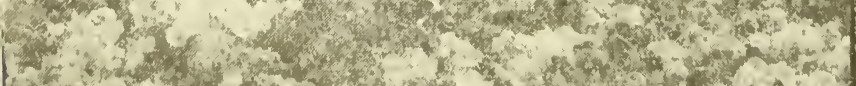

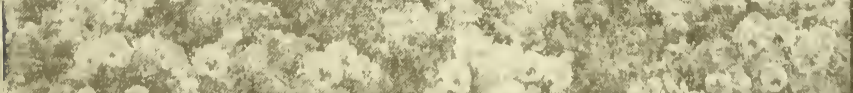

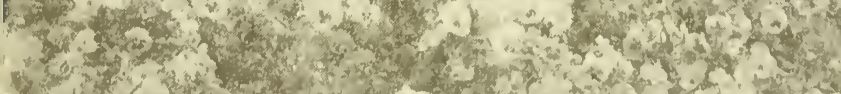

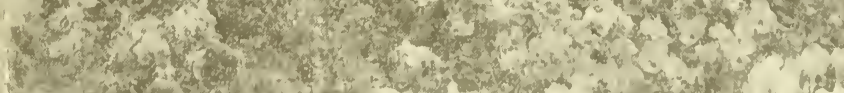

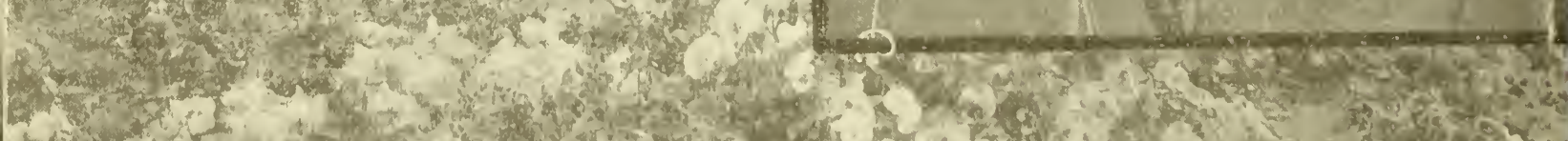

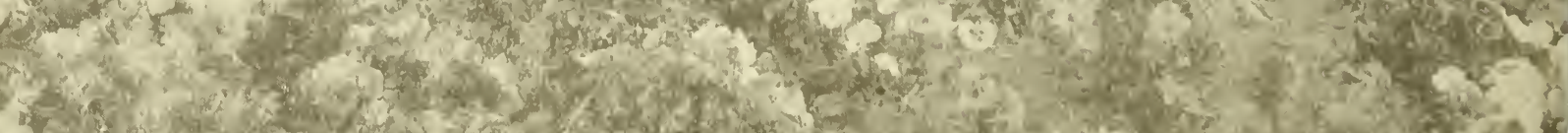

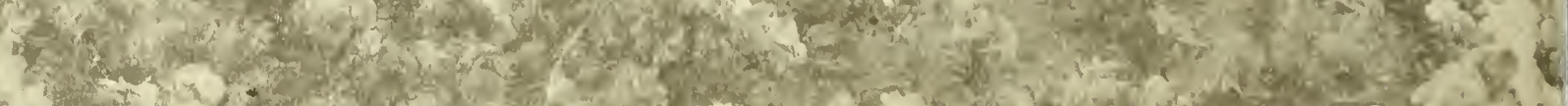

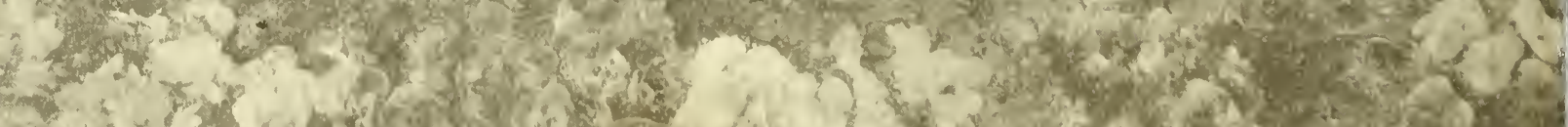

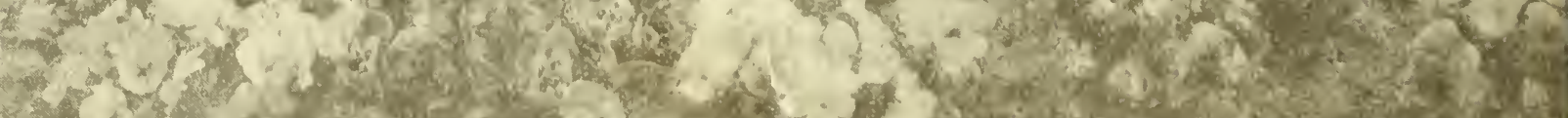

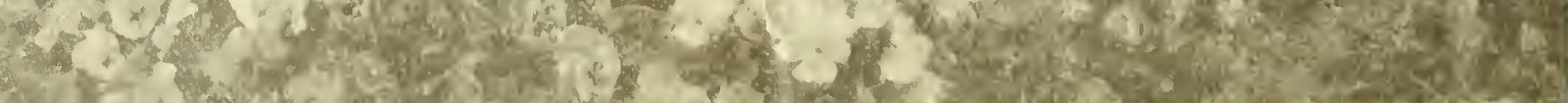

